$$
\text { USES-OFR--95-397 }
$$

\title{
STRATIGRAPHIC RELATIONS AND HYDROLOGIC PROPERTIES OF THE PAINTBRUSH TUFF NONWELDED (PTn) HYDROLOGIC UNIT, YUCCA MOUNTAIN, NEVADA
}

\section{U.S. GEOLOGICAL SURVEY}

Open-File Report 95-397

\section{WEOIVED \\ AUG 301996 \\ OSTI}

Prepared in cooperation with the

NEVADA OPERATIONS OFFICE,

U.S. DEPARTMENT OF ENERGY, under

Interagency Agreement DE-AI08-92NV10874

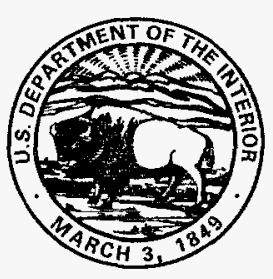




\title{
Stratigraphic Relations and Hydrologic Properties of the Paintbrush Tuff Nonwelded (PTn) Hydrologic Unit, Yucca Mountain, Nevada
}

\author{
by Thomas C. Moyer ${ }^{1}$, Jeffrey K. Geslin ${ }^{1}$, and Lorraine E. Flint ${ }^{2}$ \\ ${ }_{1}^{1}$ Science Applications International Corporation, Golden, CO \\ 2U.S. Geological Survey, Yucca Mountain Project, Mercury, NV
}

\section{U.S. GEOLOGICAL SURVEY}

Open-File Report 95-397

Prepared in cooperation with the

NEVADA OPERATIONS OFFICE, U.S. DEPARTMENT OF ENERGY, under

Interagency Agreement DE-Al08-92NV10874

\section{DISCLAIMER}

This report was prepared as an account of work sponsored by an agency of the United States Government. Neither the United States Government nor any agency thereof, nor any of their employees, makes any warranty, express or implied, or assumes any legal liability or responsibility for the accuracy, completeness, or usefulness of any information, apparatus, product, or process disclosed, or represents that its use would not infringe privately owned rights. Reference herein to any specific commercial product, process, or service by trade name, trademark, manufacturer, or otherwise does not necessarily constitute or imply its endorsement, recommendation, or favoring by the United States Government or any agency thereof. The views and opinions of authors expressed herein do not necessarily state or reflect those of the United States Government or any agency thereof.

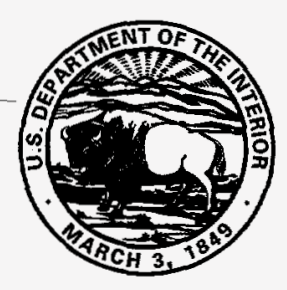




\section{U.S. DEPARTMENT OF THE INTERIOR \\ BRUCE BABBITT, Secretary \\ U.S. GEOLOGICAL SURVEY \\ Gordon P. Eaton, Director}

The use of trade, product, industry, or firm names is for descriptive purposes only and does not imply endorsement by the U.S. Government.

The stratigraphic nomenclature in this report does not conform to the usage of the U.S. Geological Survey.

For additional information write to:

Chief, Earth Science Investigations

Program

Yucca Mountain Project Branch

U.S. Geological Survey

Box 25046, MS 421

Denver Federal Center

Denver, CO 80225
Copies of this report can be purchased from:

U.S. Geological Survey

Branch of Information Services

Box 25286

Denver, CO 80225 


\section{DISCLAIMER}

Portions of this document may be illegible in electronic image products. Images are produced from the best available original document. 


\section{CONTENTS}

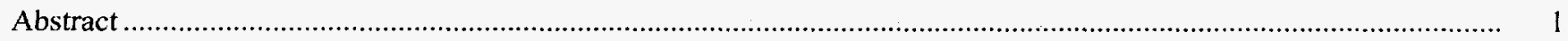

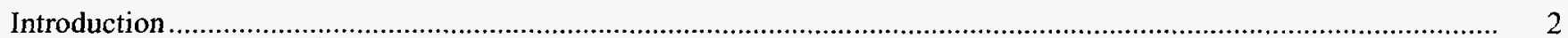

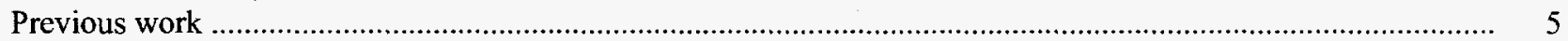

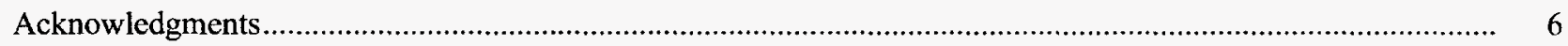

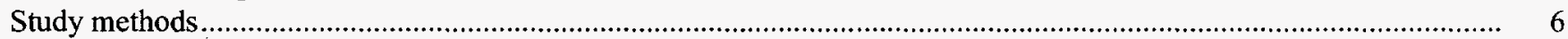

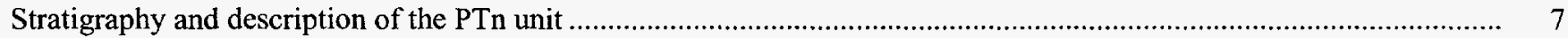

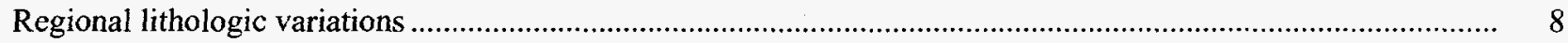

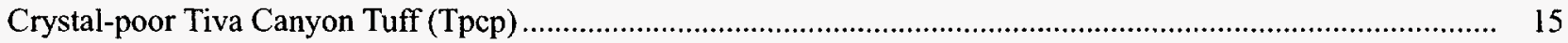

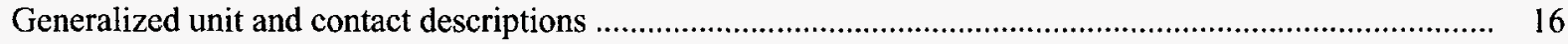

Crystal-poor lower nonlithophysal zone, columnar subzone (Tpcplnc) ...................................... 16

Crystal-poor vitric zone, moderately welded subzone (Tpcpv2) .............................................. 17

Crystal-poor vitric zone, non- to partially welded subzone (Tpcpv 1) ....................................... 17

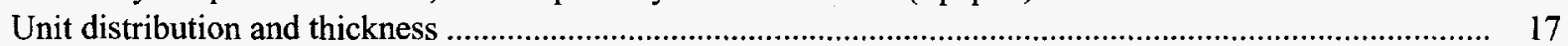

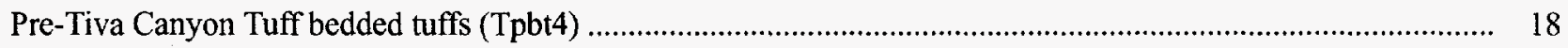

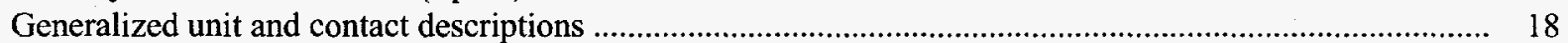

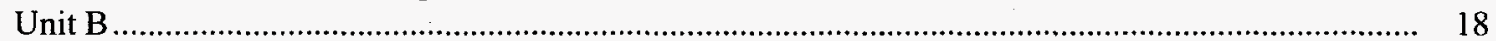

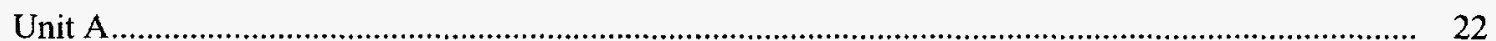

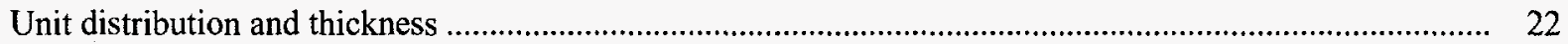

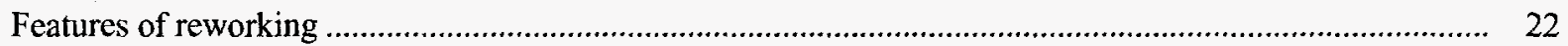

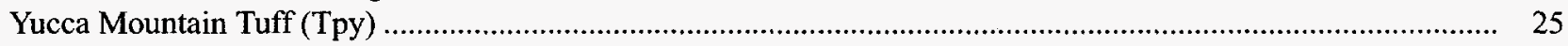

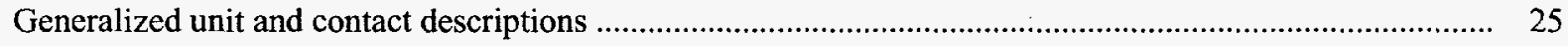

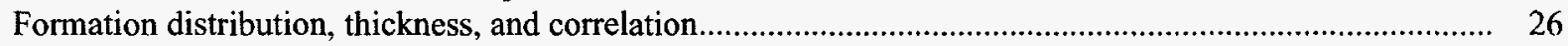

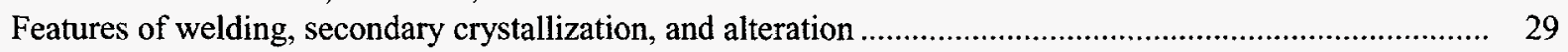

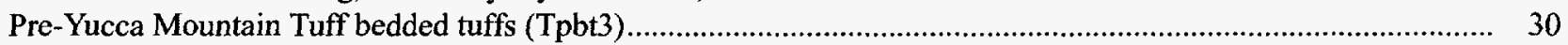

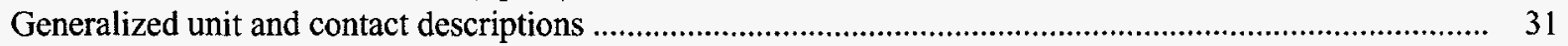

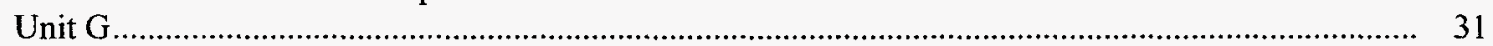

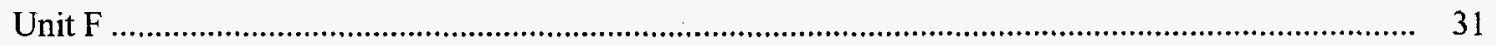

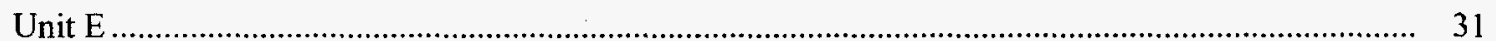

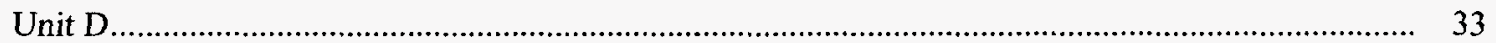

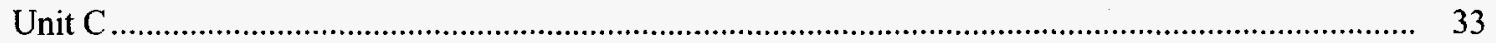

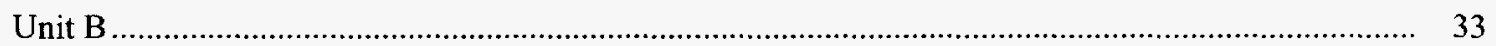

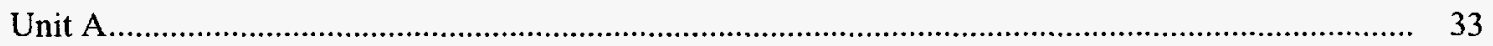

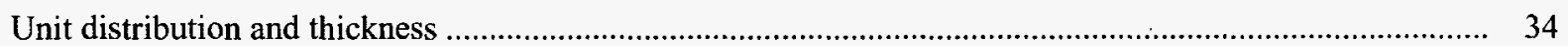

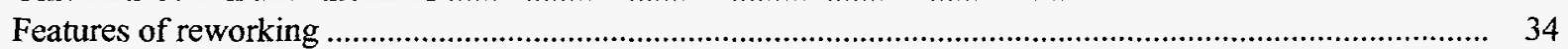

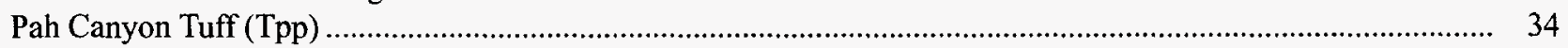

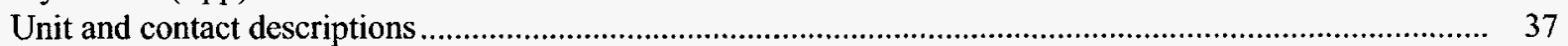

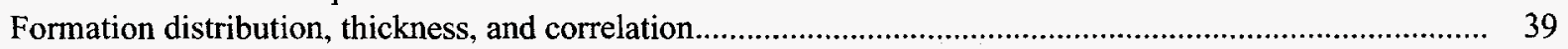

Features of welding, secondary crystallization, and alteration ...............................................................

Pre-Pah Canyon Tuff bedded tuffs (Tpbt2) and non- to partially and moderately welded subzones of

the Topopah Spring Tuff crystal-rich vitric zone (Tptrv3; Tptrv2) ..............................................................46

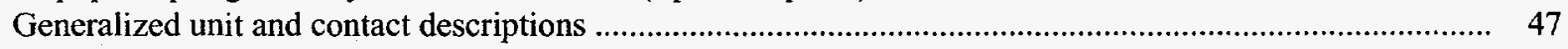

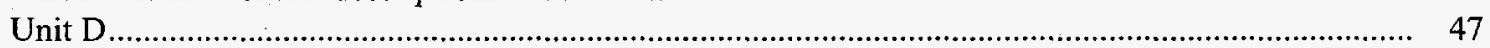

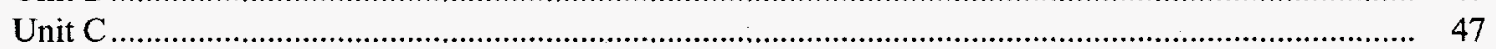

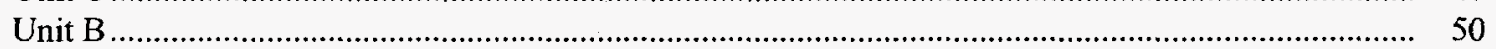

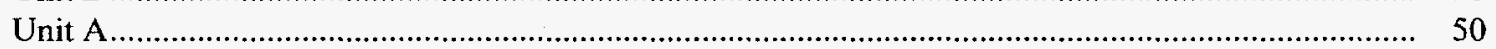

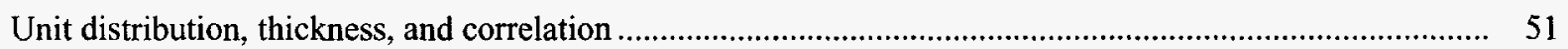

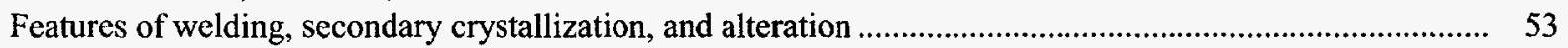




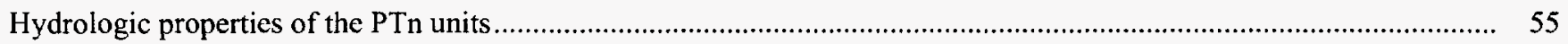

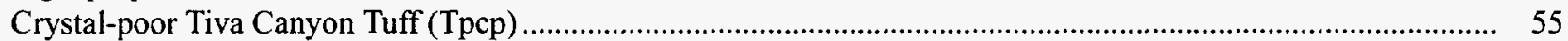

General hydrologic properties................................................................................................................ 55

Crystal-poor lower nonlithophysal zone, columnar subzone (Tpcplnc) and crystal-poor

vitric zone, moderately welded subzone (Tpcpv2) .................................................................... 55

Crystal-poor vitric zone, non- to partially welded subzone (Tpcpvl) ................................................ 56

Stratigraphic controls on hydrologic properties ........................................................................................ 57

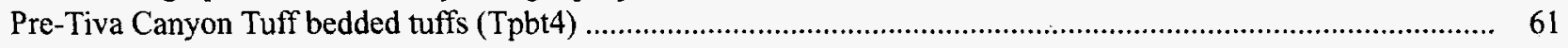

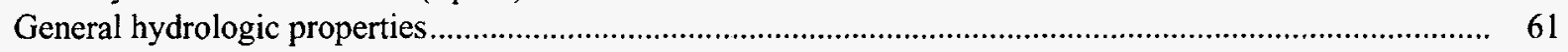

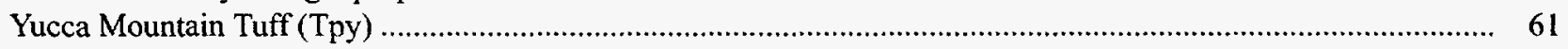

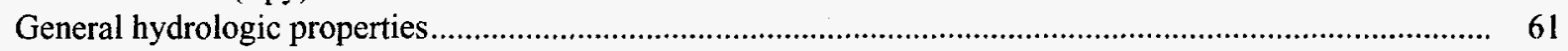

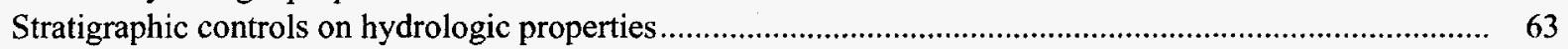

Pre-Yucca Mountain Tuff bedded tuffs (Tpbt3) ................................................................................................. 65

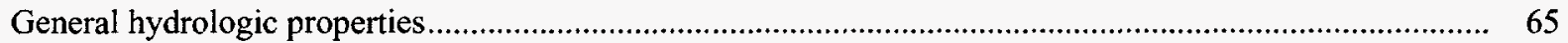

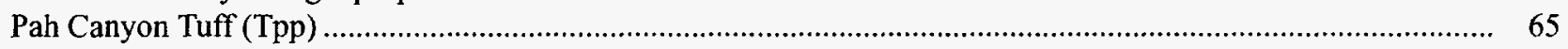

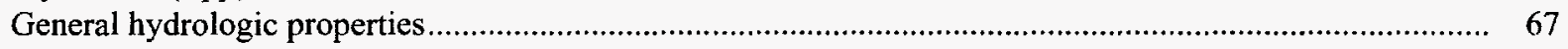

Stratigraphic controls on hydrologic properties........................................................................................... 71

Pre-Pah Canyon Tuff bedded tuffs (Tpbt2) and non- to partially and moderately welded subzones

of the Topopah Spring Tuff crystal-rich vitric zone (Tptrv3, Tptrv2) .......................................................... 71

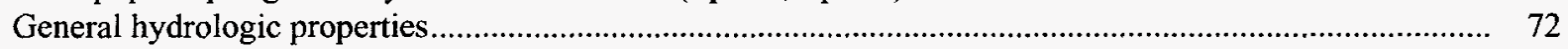

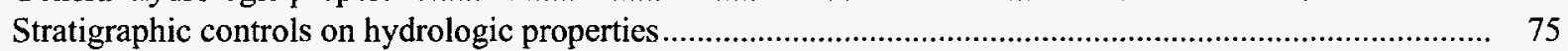

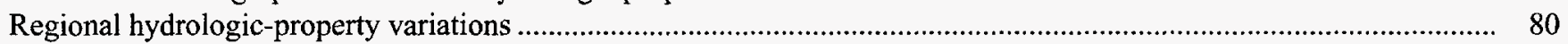

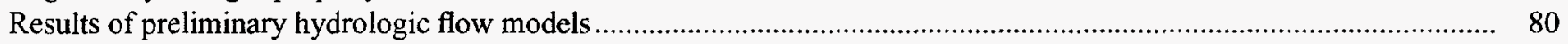

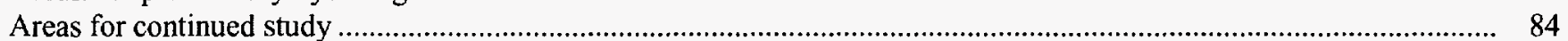

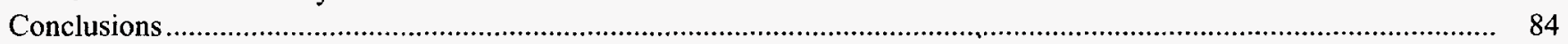

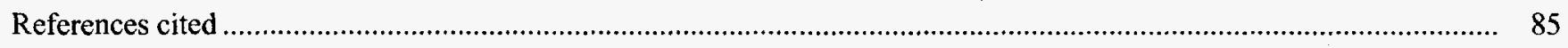

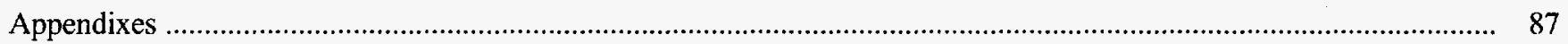

1. Supplemental lithologic data for the Paintbrush Tuff nonwelded stratigraphic units at
Yucca Mountain, Nevada ................................................................................................................

2. Measured stratigraphic sections of the Paintbrush Tuff nonwelded hydrologic unit at

Yucca Mountain, Nevada ................................................................................................................. 97

3. Depth to lithostratigraphic contacts in boreholes at Yucca Mountain, Nevada ................................................... 124

4. Hydrologic-property data for borehole samples at Yucca Mountain, Nevada ................................................. 130

\section{FIGURES}

1. Map showing the locations of boreholes and measured sections.

2. Generalized stratigraphy of the Paintbrush Group at Yucca Mountain region

3. Schematic stratigraphic column of the Paintbrush Tuff nonwelded hydrologic unit.....

4. Isochore map showing the composite apparent thickness of the Paintbrush Tuff nonwelded hydrologic unit.

5. Correlation of Paintbrush Tuff nonwelded unit strata in the central Yucca Mountain region...

6. Correlation of Paintbrush Tuff nonwelded hydrologic-unit strata along Solitario Canyon cliff................................ 14

7. Photograph of pyroclastic-flow boundary in the moderately welded subzone of the Tiva Canyon Tuff crystal-poor vitric zone taken along Solitario Canyon cliff, near measured section PTn\#8

8. Isochore map showing apparent thickness of combined non- to partially welded (Tpcpv1) and moderately welded (Tpcpv2) subzones of the Tiva Canyon Tuff crystal-poor vitric zone..

9. Correlation diagram of units in the base of Tiva Canyon Tuff exposed along the east side of Solitario Canyon. 
10. Photograph and sketch of an outcrop at measured section PTn\#11 ....

11. Photograph and sketch of pre-Tiva Canyon Tuff bedded tuffs (Tpbt4) in an outcrop near measured section PTn\#9....

12. Isochore map showing apparent thickness distribution of pre-Tiva Canyon Tuff bedded tuff (Tpbt4) unit A.

13. Photograph and sketch of upper Yucca Mountain Tuff (Tpy) along Solitario Canyon cliff, north of measured section PTn\#6.

14. Isochore map showing apparent thickness of the Yucca Mountain Tuff in cored boreholes and measured sections.

15. Photographs of cylindrical structures interpreted as burrows in the pre-Yucca Mountain Tuff bedded tuffs (Tpbt3)

16. Map showing the combined apparent thickness of all pre-Yucca Mountain Tuff bedded tuff (Tpbt3) units except unit $E$

17. Isochore map showing the apparent thickness of pre-Yucca Mountain Tuff bedded tuff (Tpbt3) unit E ............

18. Photographs of the Pah Canyon Tuff (Tpp)

19. Isochore map showing the apparent thickness of the Pah Canyon Tuff (Tpp) in cored boreholes and measured sections.

20. (A) Mean ratios of pumice shape and compensated density measured in the Pah Canyon Tuff (Tpp) plotted relative to drilled depth in borehole G-2, and (B) digital density log plotted relative to depth in borehole NRG \#4..

21. Photographs of pre-Pah Canyon Tuff bedded tuffs (Tpbt2).

22. Photograph and sketch of contact between moderately welded pumice-fall deposit and underlying densely welded pyroclastic-flow deposits of the Topopah Spring Tuff (Tptrv1) at measured section PTn\#3, Solitario Canyon cliff...

23. Map of the apparent thickness of interval from the base of the Pah Canyon Tuff to the top of the welded pyroclastic-flow deposit of the Topopah Spring Tuff determined in cored boreholes and measured sections.

24. Porosity histograms for units in the lower Tiva Canyon Tuff

25. Bulk density histograms for units in the lower Tiva Canyon Tuff.....

26. Plots of porosity and particle density for the lower Tiva Canyon Tuff in boreholes UZ-N54 and $\mathrm{UZ}-\mathrm{N} 37$

27. Plots of porosity and percent saturation for the lower Tiva Canyon Tuff in boreholes UZ-N1l and $\mathrm{UZ}-\mathrm{N} 37$, and UZ-N54 and UZ-N53.

28. Plots of saturated hydraulic conductivity and porosity for the entire Paintbrush Tuff nonwelded hydrologic unit in borehole UZ $\# 16$ and a transect through outcrop located on the east side of

Solitario Canyon.

29. Porosity and bulk density histograms for the pre-Tiva Canyon Tuff bedded tuffs (Tpbt4)

30. Histograms of hydrologic properties of the Yucca Mountain Tuff (Tpy) determined from borehole sample.

31. Histograms of particle density for the Yucca Mountain Tuff (Tpy).

32. Bulk density and porosity of the Yucca Mountain Tuff in boreholes SD-9 and UZ-N33

33. Bulk density, porosity, and particle density of the Yucca Mountain Tuff (Tpy) in borehole UZ-14 ....................

34. Porosity and percent saturation of the Yucca Mountain Tuff (Tpy) in boreholes SD-9 and UZ-N33 ................

35. Porosity and saturation of the Yucca Mountain Tuff in borehole UZ-14 ...

36. Hydrologic properties of the Yucca Mountain Tuff in a stratigraphic section near Prow Pass, plotted relative to traverse distance (stratigraphic thickness).

37. Porosity and bulk density histograms for the pre-Yucca Mountain Tuff bedded tuffs (Tpbt3).

38. Histograms of hydrologic properties of the Pah Canyon Tuff determined from borehole and outcrop samples. 
39. Bulk density and porosity of the Pah Canyon Tuff in boreholes SD-9 and UZ-14

40. Hydrologic properties of the Pah Canyon Tuff in a stratigraphic section near Prow Pass, plotted relative to traverse distance (stratigraphic thickness)

41. Histograms of bulk density for the interval from the base of the Pah Canyon Tuff to the top of the Topopah Spring Tuff crystal-rich vitrophyre.

42. Histograms of porosity for the interval from the base of the Pah Canyon Tuff to the top of the Topopah Spring Tuff crystal-rich vitrophyre

43. Hydrologic properties for the interval from the base of the Pah Canyon Tuff to the top of the Topopah Spring Tuff crystal-rich vitrophyre in borehole UZ-N32

44. Hydrologic properties for the interval from the base of the Pah Canyon Tuff to the top of the Topopah Spring Tuff crystal-rich vitrophyre in borehole SD-9

45. Hydrologic properties for the interval from the base of the Pah Canyon Tuff to the top of the Topopah Spring Tuff crystal-rich vitrophyre in borehole UZ-N54

46. Bulk density and porosity plotted relative to depth for the composite Paintbrush Tuff nonwelded hydrologic unit in boreholes UZ-N33, UZ-14, UZ-N32, and UZ \#16

47. Results of two-dimensional flow models between boreholes UZ-N53 and UZ \#16 representing the lithology and physical properties of the Tiva Canyon Tuff, Paintbrush Tuff nonwelded units, and upper Topopah Spring Tuff....

48. Results of two-dimensional flow models between boreholes UZ-14 and SD -9 representing the lithology and physical properties of the Tiva Canyon Tuff, Paintbrush Tuff nonwelded units, and upper Topopah Spring Tuff.

\section{TABLES}

1. Summary of previous work on the PTn hydrologic and thermal-mechanical unit ............................................... 5

2. Layer descriptions, thicknesses, and parameters used in hydrologic models ..................................................... 7

3. Summary of diagnostic characteristics of lithostratigraphic units in the PTn hydrologic unit.............................. 10

4. Depths to welding and crystallization features in the Yucca Mountain Tuff ....................................................... 30

5. Depths to possible flow-unit boundaries in the Pah Canyon Tuff.................................................................... 38

6. Depths to depositional, welding, and crystallization features in the Pah Canyon Tuff - borehole USW G-2........ 44

\section{CONVERSION FACTORS}

\begin{tabular}{rll}
\hline Multiply & By & To obtain \\
millimeter $(\mathrm{mm})$ & & \\
centimeter $(\mathrm{cm})$ & 0.03937 & inch (in.) \\
meter $(\mathrm{m})$ & 0.3937 & inch (in.) \\
foot (ft) \\
megapascal $(\mathrm{MPa})$ & 3.2808 & mile (mi) \\
milligrams per liter $(\mathrm{mg} / \mathrm{L})$ & 0.6214 & bars (b) \\
grams per cubic centimeter $\left(\mathrm{g} / \mathrm{cm}^{3}\right)$ & 10.0 & pound per cubic inch $\left(\mathrm{lb} / \mathrm{in}^{3}\right)$ \\
cubic centimeter per cubic centimeter $\left(\mathrm{cm}^{3} / \mathrm{cm}^{3}\right)$ & $3.61 \times 10^{-8}$ & pound per cubic inch $\left(\mathrm{lb} / \mathrm{in}^{3}\right)$ \\
\end{tabular}

Degree Celsius $\left({ }^{\circ} \mathrm{C}\right)$ may be converted to degree Fahrenheit $\left({ }^{\circ} \mathrm{F}\right)$ by using the following equation:

$$
{ }^{\circ} \mathrm{F}=9 / 5\left({ }^{\circ} \mathrm{C}\right)+32 \text {. }
$$

Sea level: In this report "sea level" refers to the National Geodetic Vertical Datum of 1929 (NGVD of 1929) —a geodetic datum derived from a general adjustment of the first-order level nets of both the United States and Canada, formerly called Sea Level Datum of 1929. 


\title{
Stratigraphic Relations and Hydrologic Properties of the Paintbrush Tuff Nonwelded (PTn) Hydrologic Unit, Yucca Mountain, Nevada
}

\author{
By Thomas C. Moyer, Jeffrey K. Geslin, and Lorraine E. Flint
}

\section{Abstract}

The Paintbrush Tuff nonwelded (PTn) hydrologic unit, which comprises the stratigraphic interval from the top of the Topopah Spring Tuff crystal-rich vitrophyre to the base of the densely welded zone in the crystal-poor member of the Tiva Canyon Tuff, includes the Pah Canyon Tuff, Yucca Mountain Tuff, and interstratified bedded tuff deposits. This report provides unit and contact descriptions for the PTn strata, describes 10 measured stratigraphic sections through the PTn unit, correlates stratigraphic units through boreholes and surface exposures, summarizes the hydrologic properties of the PTn units and examines their variability in stratigraphic context, and presents results from preliminary hydrologic models of flow through the PTn.

Several significant observations of PTn lithology are described. The Yucca Mountain and Pah Canyon Tuffs have abrupt, but poorly constrained, transitions from welded and devitrified in the north to nonwelded and vitric in the south. Several PTn units have depositional features consistent with limited reworking of primary pyroclastic material and alteration that suggests the development of incipient paleosols; evidence for widespread fluvial reworking is lacking. A pumice-fall deposit within the pre-Tiva Canyon Tuff bedded tuffs contains crossbeds consistent with local eolian reworking; the base of this unit is laminated and locally preserves features that suggest its deposition from a high-velocity flow. A discontinuous zone of locally intense argillic alter- ation occurs in the upper few meters of a sequence of pumice-fall deposits that overlie the Topopah Spring Tuff pyroclastic-flow deposit; this alteration may be related to post-emplacement degassing of the underlying ash-flow tuff. Argillic alteration in the upper part of the crystal-poor vitric zone of the Tiva Canyon Tuff is regionally extensive but highly variable in intensity. Most PTn stratigraphic units and marker horizons are laterally continuous and can be identified from the Yucca Wash area in the north to borehole GU-3 in the south. Regional correlation shows that the PTn unit thins rapidly southward and that changes in thickness are due primarily to thinning of the pyroclastic-flow deposits of the Yucca Mountain Tuff, Pah Canyon Tuff, and an unnamed pyroclastic-flow deposit between these formations.

The post-Topopah Spring Tuff pumice-fall deposits and the nonwelded Pah Canyon Tuff, where unaltered, are the most porous deposits within the PTn unit (porosity of 45 to 55 percent and dry bulk density of 1.1 to 1.2 grams per cubic centimeter). These strata have significantly lower porosity and higher density where they are locally altered to zeolite and clay minerals. In contrast, intervals of possibly reworked tephra that occur beneath the Pah Canyon Tuff and within the pre-Yucca Mountain Tuff bedded tuffs generally have less porosity ( 32 to 48 percent) and higher dry bulk density (1.2 to 1.6 grams per cubic centimeter). The Yucca Mountain Tuff exhibits abrupt changes in properties related to its history of welding, secondary crystallization, and alteration. As a 
result, borehole samples of the Yucca Mountain Tuff have porosity values that range from 2 to 45 percent and dry bulk density values that range from 1.2 to 2.2 grams per cubic centimeter.

Plots of PTn hydrologic properties relative to depth show a vertical asymmetry at the upper and lower contacts that is created by differences in the nature of the welding process; whereas the gently gradational upper contact of the PTn unit occurs within the lower Tiva Canyon Tuff, the sharply gradational lower contact typically occurs within a sequence of pumice-fall deposits welded by the underlying Topopah Spring Tuff. Post-emplacement argillic alteration of the moderately welded, crystal-poor, vitric zone of Tiva Canyon Tuff does not greatly perturb vertical profiles of bulk density and porosity but produces elevated saturation values and significant differences in porosity determined at relative humidity and at high temperature.

The results of preliminary hydrologic flow models illustrate the importance of coupling lithologic and hydrologic studies. These models demonstrate that the PTn units control the lateral flow of water in the Paintbrush Group, suggest that unit thickness within the PTn has a strong influence on lateral diversion, and show that the ability of the PTn units to transmit water laterally may preclude high levels of saturation within them. The preliminary results indicate that future models should divide the PTn unit into several hydrologic subunits that include the low-permeability base of the Tiva Canyon Tuff, moderately welded Yucca Mountain Tuff, thick sections of nonwelded Pah Canyon Tuff, and nonwelded bedded tuff layers.

\section{INTRODUCTION}

Yucca Mountain in Nye County, Nevada, is being investigated as a potential site for a high-level nuclear-waste repository. The study area, which straddles the western boundary of the Nevada Test Site, includes land under the jurisdiction of the U.S. Department of Energy, U.S. Air Force, and Bureau of Land Management. A thick section of Tertiary volcanic rocks overlies Paleozoic sedimentary strata in this region (Byers and others, 1976) (fig. 1). The volcanic strata record the evolution of at least seven calderas that compose the Timber Mountain-Oasis Valley caldera complex of the southwestern Nevada volcanic field (Byers and others, 1976; Sawyer and others, 1994).

Formations of the Paintbrush Group, erupted from 12.8 to $12.7 \mathrm{Ma}$ (Sawyer and others, 1994), form most of the exposures in the study area (Christiansen and Lipman, 1965; Scott and Bonk, 1984) (fig. 1). Yucca Mountain is underlain by two voluminous, densely welded and devitrified ash-flow tuffs (the Tiva Canyon and Topopah Spring Tuffs) that are separated by a comparatively thin interval of mostly nonwelded, vitric pyroclastic deposits (fig. 2). The contrasting physical properties of the nonwelded deposits led Montazer and Wilson (1984) and Ortiz and others (1985) to designate these strata as the Paintbrush Tuff nonwelded (PTn) hydrologic and thermal-mechanical units. Preliminary hydrologic models of flow through the unsaturated zone at Yucca Mountain indicate that the moderate to high porosity, permeability, and storage capacity of the PTn strata, and their abrupt, but gradational upper and lower contacts, may strongly influence the downward percolation of surface water and the upward or lateral flow of fluids in the unsaturated zone that overlies the potential repository site (Montazer and Wilson, 1984; Kwicklis and others, 1993, 1994). As such, lithologic and stratigraphic characterization of the PTn unit is critical to site suitability studies.

The intent of this study was to clarify stratigraphic relations within the PTn unit at Yucca Mountain in order to better understand vertical and lateral variations in hydrologic properties as they relate to the lithologic character of these rocks. This report defines informal stratigraphic units within the PTn interval, demonstrates their lateral continuity in the Yucca Mountain region, describes lateral and vertical variations within them, and characterizes their hydrologic properties and importance to numerical flow and transport models. We present tables summarizing the depth to stratigraphic contacts in cored boreholes, unit and contact descriptions developed from borehole studies, and unit descriptions and correlations in 10 measured sections. 


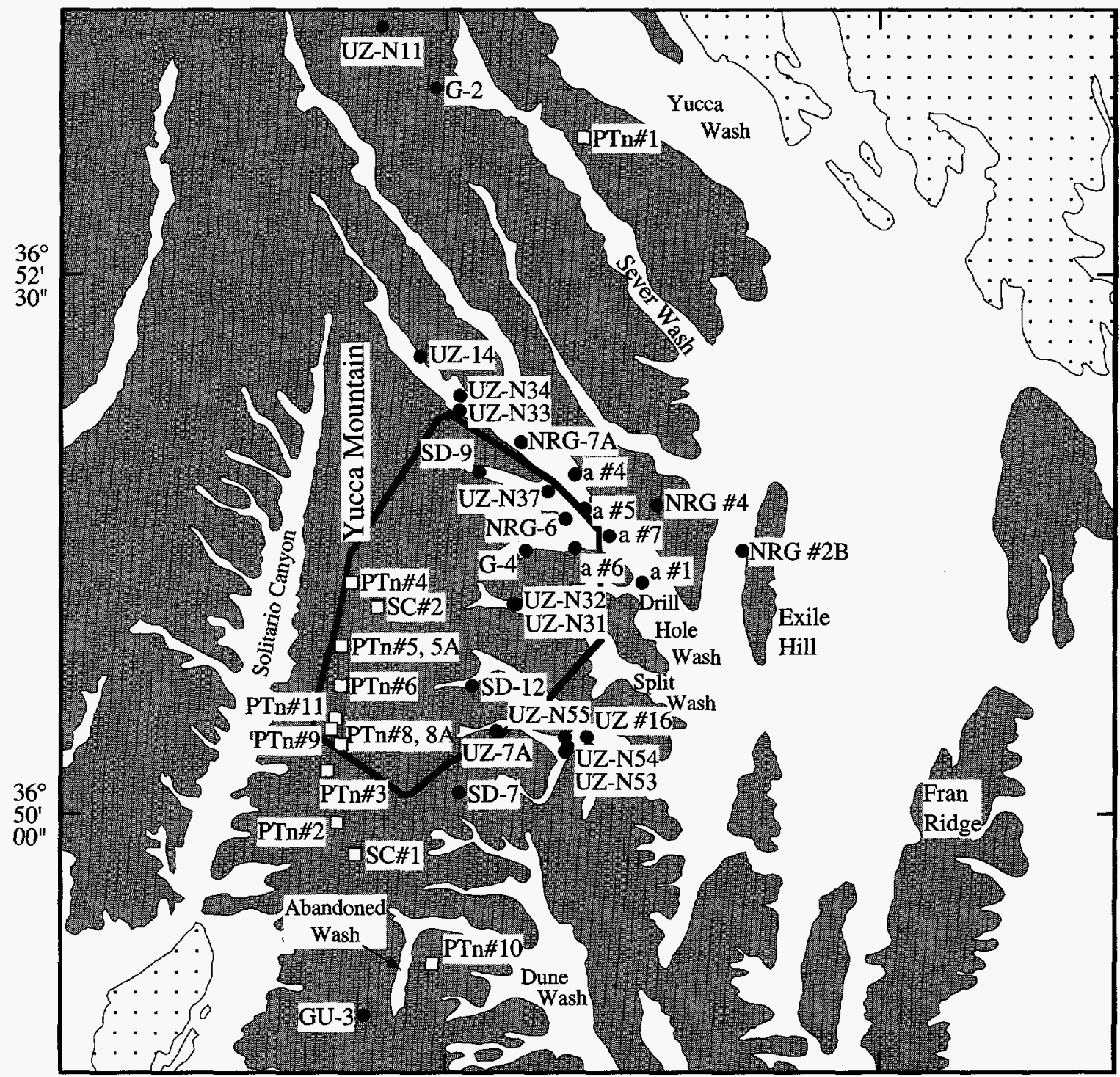

EXPLANATION

Boundary of potential repository area
$\square$ - Alluvium and colluvium
- Outcrop of Paintbrush Group
tuffaceous rocks
$\square$ - Outcrop of other Miocene
volcanic rocks
SD-12 - Borehole location and number
PTn\#11 - Measured section location and number

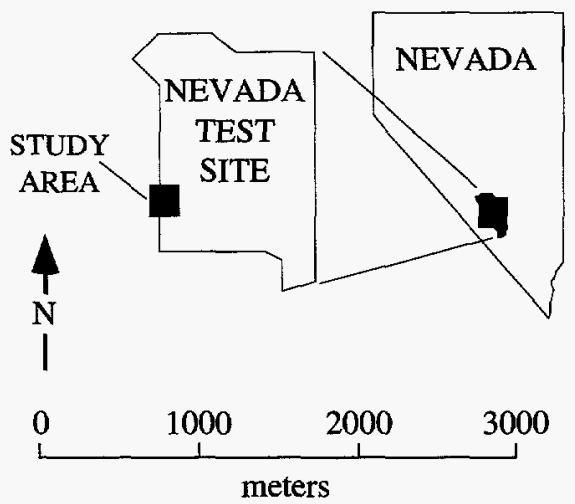

Figure 1. Locations of boreholes and measured sections discussed in this report. Heavy line shows the boundary of the potential repository. 


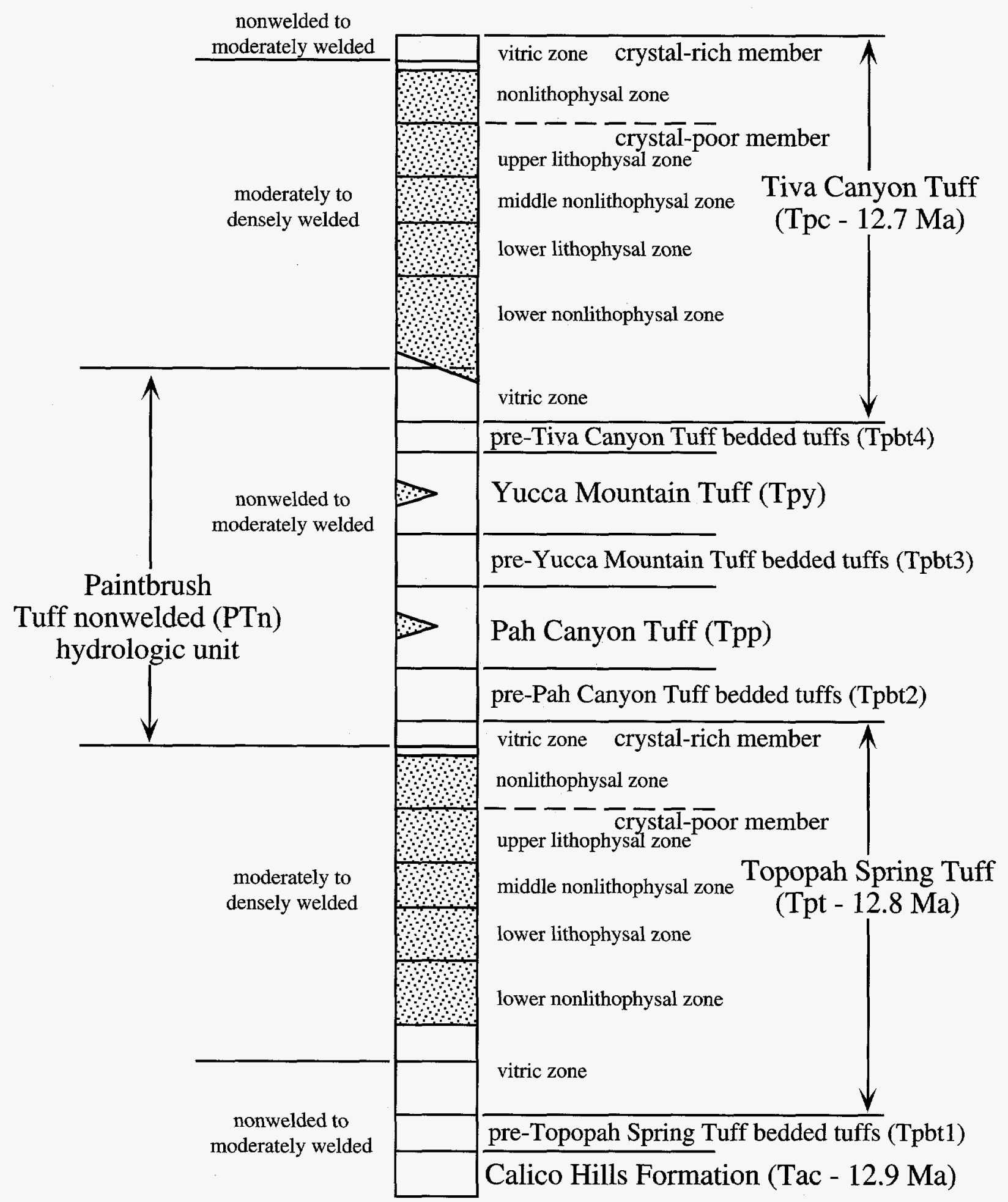

Figure 2. Generalized stratigraphy of the Paintbrush Group at Yucca Mountain region (from Buesch, Spengler, and others, 1996). Stippled regions indicate devitrified units. Ages are taken from Sawyer and others (1994). 


\section{Previous Work}

Table 1 lists previously published studies that define or describe PTn stratigraphic units and that present and discuss hydrologic properties of the PTn units. Significant conclusions and observations from these studies are annotated below.

The geology of the Yucca Mountain area was mapped and described by Christiansen and Lipman (1965), Lipman and McKay (1965), and Scott and Bonk (1984). Byers and others (1976) summarized the stratigraphy and distribution of the Paintbrush Group formations, including those in the PTn unit, and related them to eruptions of the Claim Canyon caldera. Early studies recognized that the Pah Canyon and Yucca Mountain Tuffs are simple cooling units that become thinner and less welded southward before pinching out in the central Yucca Mountain region (Lipman and Christiansen, 1964; Byers and others, 1976). These workers also noted that the Pah Canyon and Yucca
Mountain Tuffs are separated by a sequence of lavas and pyroclastic deposits; Broxton and others (1993) subsequently related the pyroclastic deposits to the eruptions of the Delirium Canyon and Black Glass Canyon rhyolite lavas.

Diehl and Chornack (1990) published a general study of bedded tuffs in the Miocene volcanic section at Yucca Mountain. These authors recognized the lateral continuity of bedded tuffs within the PTn unit and correlated them between boreholes. Moreover, they noted a general absence of reworked deposits, a lack of widespread erosion between major eruptions, and the presence of oxidized zones (weathering) within some beds.

The physical and hydrologic properties of several samples from the PTn unit were determined as part of a preliminary study of intrinsic and relative permeability, moisture retention, and general physical properties of nonwelded and bedded tuffs at Yucca Mountain (Flint and Flint, 1990). Flint and others

Table 1. Summary of previous work on the PTn hydrologic and thermal-mechanical unit

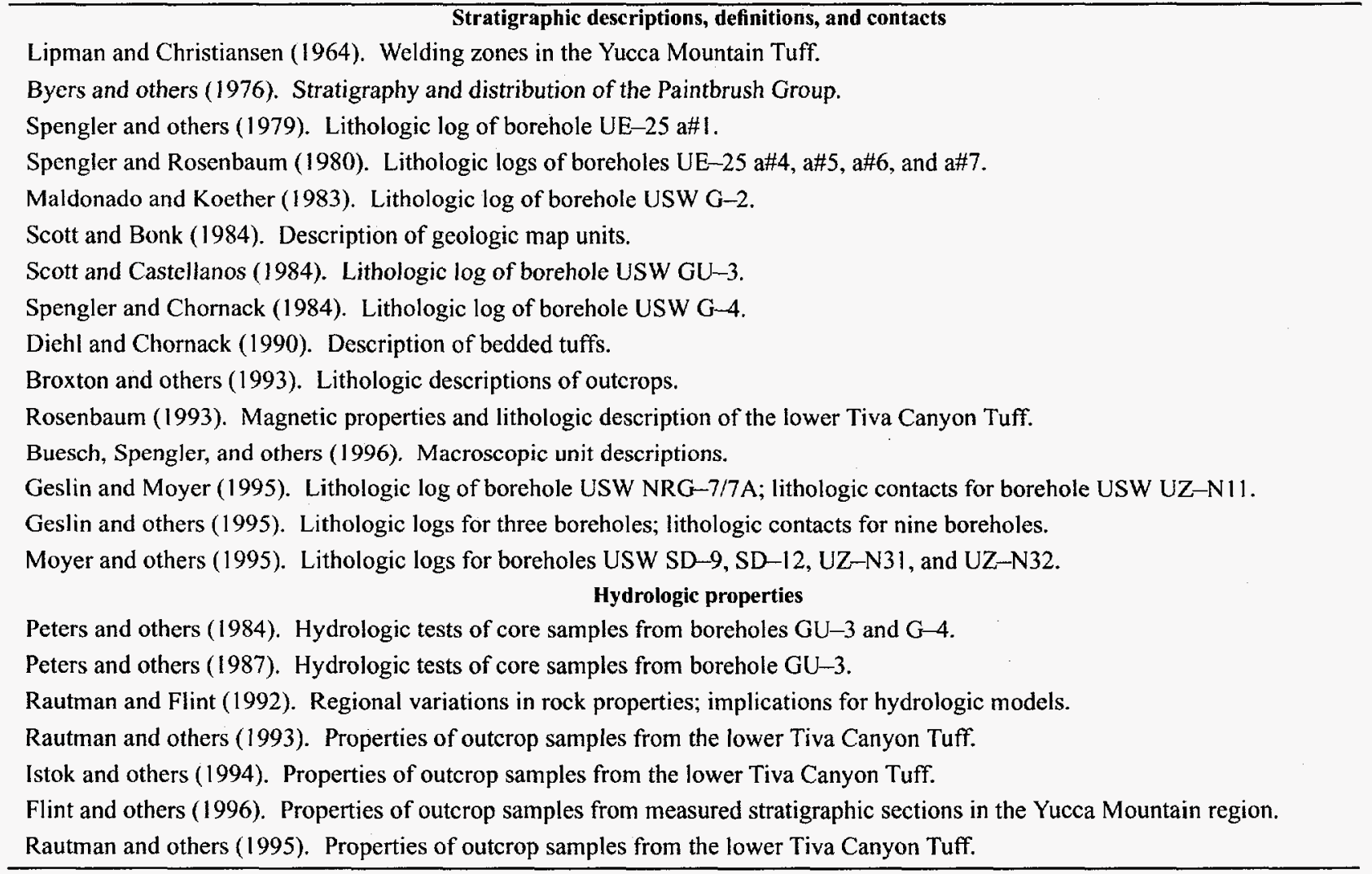


(1996) measured the physical properties of outcrop samples and described regional variations in rock properties from traverses through the volcanic sequence in the Yucca Mountain region. Rautman and others (1995) and Istok and others (1994) measured a series of stratigraphic sections in the lower Tiva Canyon Tuff exposed along the east side of Solitario Canyon. These researchers recognized two flow units within the lower $12 \mathrm{~m}$ of the deposit and a sharp upward increase in the degree of welding that begins in the upper flow unit. This transitional interval contains the first significant change in rock properties and macroscopic lithology (from densely welded to nonwelded tuff) below the present topographic surface of Yucca Mountain. As a result, this zone could act as a permeability barrier and serve as a potential lateral pathway for infiltrating ground water (Rautman and others, 1995).

\section{Acknowledgments}

We thank Richard W. Spengler for his detailed review of this paper and the data used herein. Hydrologic properties reported in appendix 4 were determined at the U.S. Geological Survey Hydrologic Research Facility at Yucca Mountain. We thank Jennifer Curtis, Kara Vidano, and Gregory Mongano for conducting the hydrologic-property analyses.

\section{STUDY METHODS}

Stratigraphic relations and unit descriptions were developed from study of core recovered from boreholes drilled as part of the Yucca Mountain Project after 1991. These data were supplemented with observations gathered from measured sections and core from older boreholes. Drill cuttings were not examined in this study.

Comparative studies of core samples and surface exposures in the Yucca Mountain region (fig. 1) were used to divide the formations of the PTn unit into informal lithostratigraphic units and to characterize variations in the degree of welding, secondary crystallization, alteration, weathering, and reworking. New and previously published hydrologic-property data were examined in stratigraphic context to constrain physical-property variability within the PTn deposits.
Lithology is the principal criterion used to subdivide the formations. Bedding features, clast size and sorting, and matrix character distinguish the nature of primary volcanic deposits (for example, pyroclastic flow or pyroclastic fall) from their secondary (redeposited) equivalents. Additional criteria used to define the lithostratigraphy included degree of welding; secondary crystallization; alteration; pumice-clast content and size; lithic-clast content, size, and lithology; matrix color, content, and composition; and phenocryst assemblage and content. Visual estimates were made of the amounts of pumice clasts, lithic clasts, and phenocrysts using charts published by Kollmorgen Instruments Corporation (1992). The phenocryst assemblage, alteration minerals, and secondary crystallization textures were characterized with the aid of a hand lens or binocular microscope. The colors of pumice clasts, lithic clasts, and matrix were described using Munsell color charts (Geological Society of America, 1991; Kollmorgen Instruments Corporation, 1992).

Hydrologic- and physical-property data utilized in this study include porosity, bulk density, particle density, saturated hydraulic conductivity, water content, and water potential. These properties were determined from borehole and outcrop samples using methods described in Flint and others (1996).

Hydrologic divisions within the PTn unit were evaluated using TOUGH (Pruess, 1987), an integrated, finite-difference code that simulates the three-dimensional coupled transport of water, vapor, air, and heat in porous and fractured media (Preuss 1987, 1991). For the purposes of modeling, the PTn unit was divided into 12 discrete layers on the basis of lithology and physical properties. Average physical parameters were computed for each layer using data determined from samples from boreholes USW NRG-6, SD-7, SD-9, SD-12, UZ-14, UZ-N31, UZ-N32, UZ-N37, UZ-N53, UZ-N54, UZ-N55, and UE-25 UZ \#16 (fig. 1; table 2). These parameters were used as input to numerically model flow in two cross sections. The first cross section was constructed between boreholes UZ-14 and SD-9 (fig. 1), where the PTn unit averages $75 \mathrm{~m}$ in thickness and where it includes significant amounts of the Pah Canyon and Yucca Mountain Tuffs. The second cross section was constructed between boreholes UZ-N53 and UZ \#16 (fig. 1), where the PTn unit averages less than $25 \mathrm{~m}$ and where the Pah Canyon Tuff is absent and the 
Yucca Mountain Tuff is thin. In both sections, an eastward dip of $6.5^{\circ}$ was used to simulate the structurally tilted beds of the PTn and to allow for lateral fluxes if high saturations developed. To establish steady-state conditions in each simulation, a bottom boundary was set with a fixed water potential representing measured field conditions of about $1 \mathrm{MPa}$, and lateral boundaries were set to no-flow conditions. Once steady state was achieved, the downslope lateral boundary was changed to a flow boundary to ensure against ponding, the conductivity of the overlying welded Tiva Canyon Tuff was increased by two orders of magnitude to simulate the contribution of fracture permeability, and fluxes of $0.1 \mathrm{~mm} / \mathrm{yr}$ and $1 \mathrm{~mm} / \mathrm{yr}$ were applied at the surface. Saturations and fluxes were computed for each grid location. These models help to identify the lithologic layers that control the development of high saturations and lateral diversions and point out layers that do not merit separate hydrologic designation.

\section{STRATIGRAPHY AND DESCRIPTION OF THE PTn UNIT}

Figure 2 illustrates the general stratigraphy of the Paintbrush Group at Yucca Mountain using the stratigraphic nomenclature of Buesch, Spengler, and others (1996). The PTn hydrologic unit as defined by Montazer and Wilson (1984) comprises the stratigraphic interval from the base of the densely welded zone of the Tiva Canyon Tuff and the top of the densely welded zone of the Topopah Spring Tuff. Included are the moderately welded and non- to partially welded subzones of the crystal-poor vitric zone of the Tiva Canyon Tuff (Tpcpv2 and Tpcpv1, respectively), the pre-Tiva Canyon Tuff bedded tuffs (Tpbt4), the Yucca Mountain Tuff (Tpy), the pre-Yucca Mountain Tuff bedded tuffs (Tpbt3), the Pah Canyon Tuff (Tpp), the pre-Pah Canyon Tuff bedded tuffs (Tpbt2), and the non- to partially welded and moderately welded subzones of the crystal-rich vitric zone of the Topopah Spring Tuff (Tptrv3 and Tptrv2, respectively).

Table 2. Layer descriptions, thicknesses, and parameters used in hydrologic models

[m, meter; $\mathrm{cm}^{3}$, cubic centimeter; g, gram; Pa, pascals; *, approximate unit lithology-model layers defined by porosity variations]

\begin{tabular}{|c|c|c|c|c|c|c|c|c|}
\hline \multirow{2}{*}{$\begin{array}{l}\text { Model } \\
\text { layer }\end{array}$} & \multirow{2}{*}{$\begin{array}{c}\text { Lithostratigraphic } \\
\text { unit } \\
\text { description }\end{array}$} & \multicolumn{2}{|c|}{$\begin{array}{c}\text { Model layer } \\
\text { thickness }^{1}\end{array}$} & \multirow{2}{*}{$\begin{array}{l}\text { Porosity } \\
\left(\mathrm{cm}^{3} / \mathrm{cm}^{3}\right)\end{array}$} & \multirow{2}{*}{$\begin{array}{l}\text { Particle } \\
\text { density } \\
\left(\mathrm{g} / \mathrm{cm}^{3}\right)\end{array}$} & \multirow{2}{*}{$\begin{array}{l}\text { Perme- } \\
\text { ability } \\
\left(\mathrm{m}^{2}\right)\end{array}$} & \multicolumn{2}{|c|}{$\begin{array}{c}\text { van Genuchten } \\
\text { parometers }\end{array}$} \\
\hline & & $\begin{array}{l}\text { South } \\
\text { (m) }\end{array}$ & $\begin{array}{l}\text { North } \\
\text { (m) }\end{array}$ & & & & $\begin{array}{c}\text { alpha } \\
(\mathrm{Pa})\end{array}$ & m \\
\hline $\mathrm{TCW}$ & Tpc, densely welded & 40 & 12 & 0.08 & 2.50 & $1 \mathrm{E}-18$ & $1.1 \mathrm{E}-6$ & 0.320 \\
\hline SB3 & Tpcpv2 & 1 & 3 & 0.20 & 2.42 & $5 \mathrm{E}-17$ & $1.4 \mathrm{E}-7$ & 0.516 \\
\hline SB2 & Tpcpv2 and Tpcpv1 & 2 & 4 & 0.30 & 2.40 & $5 \mathrm{E}-16$ & $4.1 \mathrm{E}-6$ & 0.235 \\
\hline SB1 & Tpcpvl & 3 & 4 & 0.40 & 2.35 & $1 \mathrm{E}-13$ & $3.1 \mathrm{E}-5$ & 0.253 \\
\hline BT4 & Tpbt4 & & 2 & 0.44 & 2.46 & $1 \mathrm{E}-13$ & $1.4 \mathrm{E}-5$ & 0.213 \\
\hline YM3 & Tpy, nonwelded & 2 & 3 & 0.42 & 2.20 & $5 \mathrm{E}-14$ & $2.8 \mathrm{E}-5$ & 0.286 \\
\hline YM2 & Tpy, moderately welded & & 7 & 0.20 & 2.30 & $5 \mathrm{E}-15$ & $3.8 \mathrm{E}-6$ & 0.437 \\
\hline YM1 & Tpy, nonwelded & & 4 & 0.32 & 2.50 & $1 \mathrm{E}-13$ & $5.6 \mathrm{E}-6$ & 0.231 \\
\hline BT3 & Tpbt3 & 4 & 6 & 0.38 & 2.43 & $1 E-13$ & $1.0 \mathrm{E}-5$ & 0.315 \\
\hline $\mathrm{PCl}$ & $\mathrm{Tpp}$ & & 32 & 0.48 & 2.25 & $1 E-13$ & $3.8 \mathrm{E}-6$ & 0.480 \\
\hline BT2 & Tpbt2 & 6 & 6 & 0.55 & 2.30 & $5 E-12$ & $3.5 \mathrm{E}-5$ & 0.281 \\
\hline $\mathrm{TN} 2$ & Tptrv3* & 3 & 4 & 0.55 & 2.38 & $1 E-12$ & $3.0 \mathrm{E}-5$ & 0.281 \\
\hline $\mathrm{TN} 1$ & Tptrv2* & 2 & 2 & 0.28 & 2.28 & $1 \mathrm{E}-15$ & $8.0 \mathrm{E}-6$ & 0.512 \\
\hline $\mathrm{TCl}$ & Tptrv1* & 1 & 1 & 0.03 & 2.50 & $1 E-19$ & $2.7 \mathrm{E}-6$ & 0.289 \\
\hline TR2 & Tptrn 2* & 1 & 10 & 0.08 & 2.52 & $1 E-18$ & $1.1 \mathrm{E}-6$ & 0.320 \\
\hline TRI & Tptrnl* & 5 & 5 & 0.18 & 2.58 & $1 E-16$ & $5.9 \mathrm{E}-6$ & 0.428 \\
\hline
\end{tabular}

${ }^{1}$ South cross section between boreholes UZ-N53 and UZ \#16; north cross section between UZ-14 and SD-9. 
In this section, the PTn strata are divided into informal subunits that can be traced throughout the Yucca Mountain region (fig. 3). The general lithologic and hydrologic character of these units is summarized in table 3. This section begins with an overview of the regional lithologic character of the PTn strata. Succeeding segments, arranged in descending stratigraphic order, provide generalized unit and contact descriptions for the Paintbrush Group formations and the interstratified bedded tuffs that compose the PTn unit, discusses their general distribution and correlation, summarizes their vertical and lateral variability, and presents macroscopic observations of welding, secondary crystallization, alteration, and reworking. Appendix 1 provides more detailed descriptive data and lists borehole and measured section intervals where units and their representative features are well preserved. Unit thicknesses and descriptions from measured sections are given in appendix 2 . Appendix 3 lists the depths to unit contacts in cored boreholes.

\section{Regional Lithologic Variations}

The PTn unit is composed primarily of interbedded pumiceous fallouts and variably welded pyroclastic-flow deposits; reworked tuffaceous material forms a minor component. The unit thins markedly from north to south across Yucca Mountain (fig. 4). In the Sever Wash-Azreal Ridge area, approximately $3 \mathrm{~km}$ north of the potential repository boundary, the PTn unit exceeds $150 \mathrm{~m}$ apparent thickness. Within the potential repository site, the apparent thickness of the PTn unit ranges from slightly more than $60 \mathrm{~m}$ in the north to slightly less than $30 \mathrm{~m}$ in the south. The limited data from south of the potential repository site indicate that the unit has a comparatively consistent thickness in this region.

Most of the thickness variation of the composite PTn unit is attributable to southward thinning of three units. The Yucca Mountain Tuff thins abruptly within the potential repository site and is absent in southern boreholes and outcrops. A nonwelded pyroclasticflow deposit within the pre-Yucca Mountain Tuff bedded tuffs (designated as unit Tpbt3E; fig. 3) varies in apparent thickness from more than $30 \mathrm{~m}$ in the Sever Wash-Azreal Ridge area to less than $30 \mathrm{~cm}$ at the northern boundary of the potential repository site. The
Pah Canyon Tuff, which exceeds $60 \mathrm{~m}$ apparent thickness in the Azreal Ridge area, thins from slightly less than $30 \mathrm{~m}$ to less than $3 \mathrm{~m}$ across the potential repository site before pinching out near the southern site boundary. The remaining strata within the PTn unit vary insignificantly across the region.

Figures 5 and 6 illustrate that, despite the significant variation in PTn composite thickness, the lithostratigraphic units defined in this report can be correlated across the Yucca Mountain region. Importantly, it is possible to identify the stratigraphic horizons at which the Yucca Mountain Tuff, unit E of the pre-Yucca Mountain Tuff bedded tuffs, and the Pah Canyon Tuff would occur in areas where they are absent (note the locations where Tpp and Tpy pinch out in figs. 5 and 6). This allows the physical properties of PTn samples to be compared in stratigraphic context and permits straightforward evaluation of lateral variability in the hydrologic properties of individual units or beds. Moreover, knowledge of regional correlations can be used to estimate offset in regions where the PTn unit is structurally thinned and to constrain stratigraphic relations in boreholes where recovery is poor.

As shown in figures 5 and 6 (also see fig. 3 and appendix 3), several key beds can be used to determine stratigraphic context. Distinctive marker horizons found throughout the Yucca Mountain region include ash layers 1 and 2 and unit $D$ of the pre-Pah Canyon Tuff bedded tuffs, units A, D, and F of the pre-Yucca Mountain Tuff bedded tuffs, and the incipient paleosol of unit $B$ of the pre-Tiva Canyon Tuff bedded tuffs (fig. 3 and table 3 ).

The PTn unit is predominantly nonwelded within the potential repository-site area. Exceptions include the upper and lower contacts, where PTn deposits grade from nonwelded to densely welded, and the Yucca Mountain Tuff in the northern part of the potential site area, which varies from nonwelded to partially welded. The Yucca Mountain Tuff becomes increasingly welded northward and displays an abrupt transition from wholly vitric to partially vitric with a devitrified interior near the northern repository boundary. The character of this transition and its exact location cannot be determined from the available data. A similar, but more poorly constrained, welding transition occurs within the Pah Canyon Tuff in the region north of the potential repository site. 


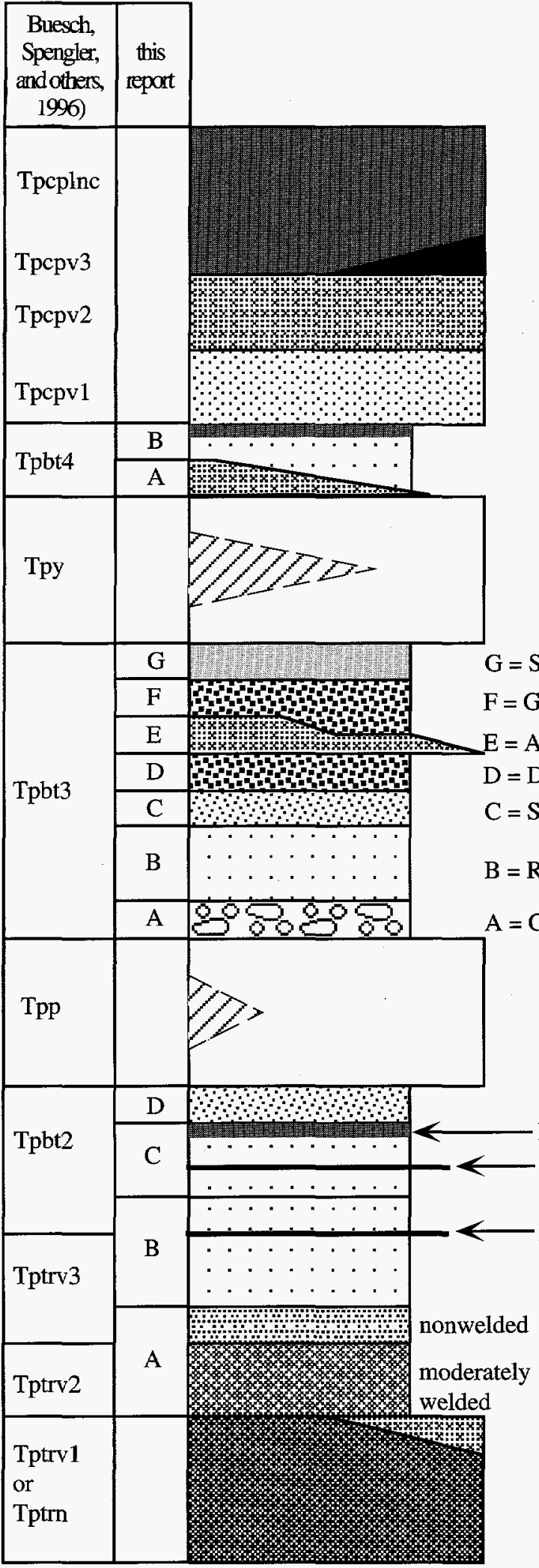

\section{Tiva Canyon Tuff}

Moderately to densely welded, devitrified, pyroclastic-flow deposit

Densely welded, vitric, pyroclastic-flow deposit (present only in south)

Moderately welded, vitric

Non- to partially welded, vitric

Pre-Tiva Canyon Tuff bedded tuff

$\mathrm{B}=$ Pumice-fall deposit

A = Pyroclastic-flow deposit

\section{Yucca Mountain Tuff}

Pyroclastic-flow deposit - welded to north

Pre-Yucca Mountain Tuff bedded tuff

$G=$ Slightly reworked, pumiceous fallout deposit

$=$ Gray glass lithic-clast fallout deposit

$B=$ Reworked, matrix-rich, pumiceous fallout deposit

$A=$ Coarse-grained, pumiceous fallout deposit

\section{Pah Canyon Tuff}

Pyroclastic-flow deposits - welded to north

\section{Pre-Pah Canyon Tuff bedded tuff}

$D=$ Reworked tuff

Red argillic alteration horizon

Upper 2-cm-thick ash layer

$\mathrm{C}=$ very pale orange to light gray fallout deposit

Lower 2-cm-thick ash layer

Topopah Spring Tuff - pumice-fall deposit $\mathrm{B}=$ light brown fallout deposit

$\mathrm{A}=$ gray, variably welded fallout deposit

Topopah Spring Tuff - pyroclastic-flow deposit

Densely welded, pyroclastic-flow deposit, locally overlain by moderately welded pyroclastic-flow deposit

Figure 3. Schematic stratigraphic column of the Paintbrush Tuff nonwelded hydrologic unit. Paintbrush Group nomenclature shown on left follows Buesch, Spengler, and others (1996). Informal units defined in this report indicated by capital letters. 
Table 3. Summary of diagnostic characteristics of lithostratigraphic units in the PTn hydrologic unit

[Paintbrush Group nomenclature follows Buesch, Spengler, and others (1996). Thickness values are from core measurements and represent drilled thicknesses and not stratigraphic thicknesses. Thicknesses in meters (m) converted from original measurements in feet. $\mathrm{cm}$, centimeter; $\mathrm{g}$, gram; pct, percent; $\mathrm{mm}$, millimeter; ${ }^{*}$ indicates limited physical-property data available for unit]

\begin{tabular}{|c|c|c|c|c|c|c|c|c|}
\hline Unit & $\begin{array}{l}\text { Type of } \\
\text { deposit }\end{array}$ & $\begin{array}{c}\text { Thickness } \\
\text { range }\end{array}$ & Welding & $\begin{array}{c}\text { Lithologic } \\
\text { characteristics }\end{array}$ & Bedding & Alteration & $\begin{array}{c}\text { Porosity } \\
\text { range } \\
\left(\mathrm{cm}^{3} / \mathrm{cm}^{3}\right)\end{array}$ & $\begin{array}{l}\text { Density } \\
\text { range } \\
\left(\mathrm{g} / \mathrm{cm}^{3}\right)\end{array}$ \\
\hline \multicolumn{9}{|c|}{ Tiva Canyon Tuff (Tpc) } \\
\hline plnc & $\begin{array}{l}\text { Pyroclastic- } \\
\text { flow }\end{array}$ & 3.6 to $0 \mathrm{~m}$ & $\begin{array}{l}\text { Moderate at } \\
\text { base to dense } \\
\text { at top of unit }\end{array}$ & $\begin{array}{l}\text { Devitrified, grayish-orange matrix and light-brown } \\
\text { shards; deformed pumice clasts are brown and } \\
\text { devitrified or black and vitric; visible porosity. }\end{array}$ & $\begin{array}{l}\text { Massive with } \\
\text { local flow } \\
\text { boundaries }\end{array}$ & $\begin{array}{l}\text { Argillic alteration } \\
\text { common at base } \\
\text { of unit }\end{array}$ & $\begin{array}{l}0.11 \text { to } 0.49 \\
\quad \text { (mean } 0.23 \text { ) }\end{array}$ & $\begin{array}{l}1.28 \text { to } 2.13 \\
\quad(\text { mean } 1.88)\end{array}$ \\
\hline pv2 & $\begin{array}{l}\text { Pyroclastic- } \\
\text { flow }\end{array}$ & 5.2 to $0.5 \mathrm{~m}$ & $\begin{array}{l}\text { Moderate, } \\
\text { increases } \\
\text { from base } \\
\text { to top }\end{array}$ & $\begin{array}{l}\text { Vitric, light-brown to gray matrix and black to } \\
\text { brown shards; deformed pumice clasts are gray- } \\
\text { ish pink and altered or white to gray and vitric; } \\
\text { rock breaks across grain boundaries. }\end{array}$ & $\begin{array}{l}\text { Massive with } \\
\text { local flow } \\
\text { boundaries }\end{array}$ & $\begin{array}{l}\text { Argillic alteration } \\
\text { common at top } \\
\text { of unit, rare } \\
\text { throughout }\end{array}$ & $\begin{array}{l}0.08 \text { to } 0.43 \\
\quad \text { (mean } 0.23 \text { ) }\end{array}$ & $\begin{array}{l}1.35 \text { to } 2.11 \\
\quad \text { (mean } 1.76)\end{array}$ \\
\hline pvl & $\begin{array}{l}\text { Pyroclastic- } \\
\text { flow }\end{array}$ & 9.6 to $1.5 \mathrm{~m}$ & $\begin{array}{l}\text { Non- to partial, } \\
\text { increasing } \\
\text { upward }\end{array}$ & $\begin{array}{l}\text { Vitric, yellowish-orange to light-gray matrix and } \\
\text { black to light-brown shards; up to } 30 \text { pct pum- } \\
\text { ice clasts near base; rock breaks around shard } \\
\text { boundaries. }\end{array}$ & $\begin{array}{l}\text { Massive, flow } \\
\text { boundaries, } \\
\text { basal ground } \\
\text { layer }\end{array}$ & $\begin{array}{l}\text { Argillic alteration } \\
\text { rare at top } \\
\text { of unit }\end{array}$ & $\begin{array}{l}0.13 \text { to } 0.55 \\
\quad \text { (mean } 0.36)\end{array}$ & $\begin{array}{l}1.02 \text { to } 1.94 \\
\quad(\text { mean } 1.44)\end{array}$ \\
\hline
\end{tabular}

Nonwelded Light-gray pumice clasts, $90-95$ pct, $1-3 \mathrm{~mm}$;

and colian

Unit A Pyroclastic-
flow

1.1 to $0 \mathrm{~m} \quad$ Nonwelded

$\begin{array}{ccc}\begin{array}{c}\text { Pyroclastic- } \\ \text { flow }\end{array} & 28.9 \text { to } 0 \mathrm{~m} & \begin{array}{l}\text { Moderate in } \\ \text { northern } \\ \text { site area to } \\ \text { nonwelded } \\ \text { in south }\end{array}\end{array}$

$\begin{array}{llll}\text { Unit } \mathrm{G} & \begin{array}{c}\text { Weathered } \\ \text { pyroclastic- } \\ \text { fall }\end{array} & 1.5 \text { to } 0 \mathrm{~m} & \text { Nonwelded } \\ \text { Unit } F & \begin{array}{c}\text { Pyroclastic- } \\ \text { fall }\end{array} & 0.8 \text { to } 0 \mathrm{~m} & \text { Nonwelded }\end{array}$

basal parallel laminae overlain by massive pumice fall; rapid lateral thickness changes; pink incipient paleosol.

Brown matrix with abundant yellowish-orange shards; distinctive black obsidian lithic clasts; very crystal poor; observed only in boreholes in eastern site area. brown to light gray where nonwelded and vitric, gray-brown to grayish orange if partially to moderately welded and devitrified; locally, top

is disturbed, brown, and contains colorless, poorly vesicular glass lithic clasts.

\section{Pre-Yucca Mountain Tuff bedded tuff}

\section{(Tpbt3)}

Light brown, clasts supported with $40-85 \mathrm{pct}$ white, $1-4 \mathrm{~mm}$, vitric pumice clasts; $10-50 \mathrm{pct}$ lithic clasts including dominant colorless, perlitic glass.

Light gray, moderately to poorly sorted, with distinctive abundant gray to colorless, perlitic, glass lithic clasts; $40-80 \mathrm{pct}$ white to gray pumice clasts.

\begin{tabular}{|c|c|c|c|}
\hline $\begin{array}{l}\text { Massive, local } \\
\text { eolian cross- } \\
\text { bedding, basal } \\
\text { laminations }\end{array}$ & $\begin{array}{l}\text { Typically } \\
\text { unaltered }\end{array}$ & $\begin{array}{l}0.56^{*} \\
\text { (one analysis) }\end{array}$ & $\begin{array}{l}0.99^{*} \\
\quad \text { (one analysis) }\end{array}$ \\
\hline Massive & $\begin{array}{l}\text { Typically } \\
\text { unaltered }\end{array}$ & $\begin{array}{l}0.31 \text { to } 0.36 \\
\quad(\text { mean } 0.34)^{*}\end{array}$ & $\begin{array}{l}1.46 \text { to } 1.52 \\
\quad \text { (mean } 1.49)^{*}\end{array}$ \\
\hline $\begin{array}{l}\text { Massive with } \\
\text { ground layer, } \\
\text { top is locally } \\
\text { brecciated }\end{array}$ & $\begin{array}{l}\text { Local argillic alter- } \\
\text { ation at base } \\
\text { of devitrified } \\
\text { interval }\end{array}$ & $\begin{array}{l}\text { Non- to partially } \\
\text { welded: } 0.26 \\
\text { to } 0.45 \text { (mean } \\
0.37 \text { ); moder- } \\
\text { ately welded: } \\
0.04 \text { to } 0.44 \\
\text { (mean } 0.24 \text { ) }\end{array}$ & $\begin{array}{l}\text { Non- to partially } \\
\text { welded: } 1.26 \\
\text { to } 1.53 \text { (mean } \\
1.39 \text { ); moder- } \\
\text { ately welded: } \\
1.25 \text { to } 2.16 \\
\text { (mean } 1.78 \text { ) }\end{array}$ \\
\hline
\end{tabular}

Massive

Typically

unaltered

0.31 to 0.34 $(\text { mean } 0.33)^{*}$

53 to 1.59

Thin bedded
0.17 to 0.43 (mean 0.31$)^{*}$
1.32 to 1.99

(mean 1.59$)^{*}$ 
Table 3. Summary of diagnostic characteristics of lithostratigraphic units in the PTn hydrologic unit--Continued

\begin{tabular}{|c|c|c|c|c|c|c|c|c|}
\hline Unit & $\begin{array}{l}\text { Type of } \\
\text { deposit }\end{array}$ & $\begin{array}{l}\text { Thickness } \\
\text { range }\end{array}$ & Welding & $\begin{array}{l}\text { Lithologic } \\
\text { characteristics }\end{array}$ & Bedding & Alteration & $\begin{array}{l}\text { Porosity } \\
\text { range } \\
\left(\mathrm{cm}^{3} / \mathrm{cm}^{3}\right)\end{array}$ & $\begin{array}{l}\text { Density } \\
\text { range } \\
\left(\mathrm{g} / \mathrm{cm}^{3}\right)\end{array}$ \\
\hline \multicolumn{9}{|c|}{$\begin{array}{l}\text { Pre-Yucca Mountain Tuff bedded tuff } \\
\text { (Tpbt3)--Continued }\end{array}$} \\
\hline Unit $\mathrm{E}$ & $\begin{array}{l}\text { Pyroclastic- } \\
\text { flow and later- } \\
\text { ally equiva- } \\
\text { lent ash-fall }\end{array}$ & 44.0 to $0 \mathrm{~m}$ & Nonwelded & $\begin{array}{l}\text { Pyroclastic-flow deposits: ash-rich, white to } \\
\text { orange-pink, vitric matrix; } 5-35 \mathrm{pct} \text { pumice } \\
\text { clasts, some very large (up to } 63 \mathrm{~cm} \text { ). Ash-rich } \\
\text { fallout deposit: orange-pink with } 25-60 \mathrm{pct} \text {, } \\
\text { 1-3 mm lithic clasts. }\end{array}$ & $\begin{array}{l}\text { Massive pyro- } \\
\text { clastic flows } \\
\text { to thin ash } \\
\text { layer in south }\end{array}$ & $\begin{array}{l}\text { Typically } \\
\text { unaltered }\end{array}$ & $\begin{array}{l}0.42^{*} \\
\quad \text { (one analysis) }\end{array}$ & $\begin{array}{l}1.33^{*} \\
\quad \text { (one analysis) }\end{array}$ \\
\hline Unit $D$ & $\begin{array}{l}\text { Pyroclastic- } \\
\text { fall }\end{array}$ & 0.8 to $0.1 \mathrm{~m}$ & Nonwelded & $\begin{array}{l}\text { Coarse grained, moderately sorted, with distinctive } \\
\text { dominant devitrified lithic clasts that are altered } \\
\text { to a rust color along some bedding planes. }\end{array}$ & Thin bedded & $\begin{array}{l}\text { Typically } \\
\text { unaltered }\end{array}$ & $\begin{array}{l}0.47 \text { to } 0.50 \\
\quad(\text { mean } 0.49)^{*}\end{array}$ & $\begin{array}{l}1.13 \text { to } 1.26 \\
\text { (mean } 1.19)^{*}\end{array}$ \\
\hline Unit $C$ & $\begin{array}{l}\text { Weathered } \\
\text { pumice- } \\
\text { fall }\end{array}$ & 1.2 to $0.2 \mathrm{~m}$ & Nonwelded & $\begin{array}{l}\text { Pumiceous with } 2-10 \text { pct light-brown matrix; } \\
70-90 \text { pct white, vitric pumice clasts, } 1-3 \mathrm{~mm} \text {; } \\
\text { pumice clasts are coated with light-brown } \\
\text { matrix. }\end{array}$ & Massive & $\begin{array}{l}\text { Typically } \\
\text { unaltered }\end{array}$ & $\begin{array}{l}0.12 \text { to } 0.44 \\
\quad(\text { mean } 0.36)^{*}\end{array}$ & $\begin{array}{l}1.28 \text { to } 2.16 \\
\quad(\text { mean } 1.51)^{*}\end{array}$ \\
\hline Unit B & $\begin{array}{l}\text { Reworked, } \\
\text { pyroclastic- } \\
\text { fall (?) }\end{array}$ & 2.9 to $0 \mathrm{~m}$ & Nonwelded & $\begin{array}{l}\text { Reddish-orange matrix increases from } 15-25 \text { pct } \\
\text { at base to } 40-60 \text { pct at top of unit; pumice } \\
\text { clasts, } 30-60 \text { pct at base to } 15-20 \text { pct at top, are } \\
5-25 \mathrm{~mm} \text {, white and vitric. }\end{array}$ & $\begin{array}{l}\text { Massive, unit } \\
\text { appears to } \\
\text { be graded }\end{array}$ & $\begin{array}{l}\text { Typically } \\
\text { unaltered }\end{array}$ & $\begin{array}{l}0.30 \text { to } 0.41 \\
\quad(\text { mean } 0.35)\end{array}$ & $\begin{array}{l}1.31 \text { to } 1.55 \\
\quad(\text { mean } 1.49)\end{array}$ \\
\hline \multirow[t]{3}{*}{ Unit A } & $\begin{array}{l}\text { Pumice- } \\
\text { fall }\end{array}$ & 1.3 to $0.15 \mathrm{~m}$ & Nonwelded & $\begin{array}{l}\text { Gray, coarse grained, pumiceous; } 70-90 \text { pct light- } \\
\text { gray, vitric, pumice clasts, } 5-20 \mathrm{~mm} \text {; lithic } \\
\text { clasts, } 2-15 \text { pct, are dominantly devitrified lava. }\end{array}$ & Massive & $\begin{array}{l}\text { Typically } \\
\text { unaltered }\end{array}$ & $\begin{array}{l}0.48 \text { to } 0.53 \\
\quad(\text { mean } 0.50)^{*}\end{array}$ & $\begin{array}{l}1.11 \text { to } 1.20 \\
\text { (mean } 1.14)^{*}\end{array}$ \\
\hline & \multicolumn{6}{|c|}{ Pah Canyon Tuff (Tpp) } & & \\
\hline & $\begin{array}{l}\text { Pyroclastic- } \\
\text { flow }\end{array}$ & 71.1 to $0 \mathrm{~m}$ & $\begin{array}{l}\text { Moderate in } \\
\text { northern site } \\
\text { area to non- } \\
\text { welded in } \\
\text { south }\end{array}$ & $\begin{array}{l}\text { Typically contains distinctive orange-pink to } \\
\text { grayish-pink matrix; abundant, large pumice } \\
\text { clasts that are light gray, vitric with } 3-5 \text { pct } \\
\text { crystals, and yellowish orange, vitric with } \\
5-7 \text { pct crystals in clots; } 5-10 \text { pct crystals } \\
\text { in matrix; lithic clasts typically } 1-7 \text { pct. }\end{array}$ & $\begin{array}{l}\text { Massive with } \\
\text { several flow } \\
\text { boundaries }\end{array}$ & $\begin{array}{l}\text { Base of unit is } \\
\text { locally zeoliti- } \\
\text { cally altered }\end{array}$ & $\begin{array}{l}\text { Nonwelded } \\
0.40 \text { to } 0.61 \\
\text { (mean } 0.47 \text { ) }\end{array}$ & $\begin{array}{l}\text { Nonwelded } \\
0.88 \text { to } 1.34 \\
\text { (mean } 1.17 \text { ) }\end{array}$ \\
\hline \multicolumn{9}{|c|}{$\begin{array}{l}\text { Pre-Pah Canyon Tuff bedded tuffs } \\
\text { (Tpbt2) }\end{array}$} \\
\hline Unit D & Reworked (?) & 2.6 to $0.7 \mathrm{~m}$ & Nonwelded & $\begin{array}{l}\text { Light brown and typically matrix supported with } \\
15-40 \text { pct pumice clasts; locally, is a mix of } \\
\text { subrounded sand-sized crystals and lithic clasts. }\end{array}$ & $\begin{array}{l}\text { Massive, local } \\
\text { medium beds, } \\
\text { rare crossbeds }\end{array}$ & $\begin{array}{l}\text { Local argillic } \\
\text { pumice clasts, } \\
\text { rarely zeolitic }\end{array}$ & $\begin{array}{l}0.32 \text { to } 0.48 \\
\quad \text { (mean } 0.39 \text { ) }\end{array}$ & $\begin{array}{l}1.22 \text { to } 1.59 \\
(\text { mean } 1.41)\end{array}$ \\
\hline Unit $C$ & $\begin{array}{l}\text { Pumice- } \\
\text { fall }\end{array}$ & 8.0 to $1.9 \mathrm{~m}$ & Nonwelded & $\begin{array}{l}\text { Pale orange to white, pumiceous and moderately } \\
\text { sorted; top of unit typically marked by red argil- } \\
\text { lic zone of variable intensity; local reddish- } \\
\text { brown alteration of pumice-clast margins and } \\
\text { matrix; ash layer } 2 \text {. }\end{array}$ & $\begin{array}{l}\text { Massive, } \\
\quad \text { faint crude } \\
\text { stratification }\end{array}$ & $\begin{array}{l}\text { Argillic alteration } \\
\text { common at top } \\
\text { of unit }\end{array}$ & $\begin{array}{l}0.32 \text { to } 0.60 \\
\quad(\text { mean } 0.50)\end{array}$ & $\begin{array}{l}0.90 \text { to } 1.59 \\
\quad(\text { mean } 1.14)\end{array}$ \\
\hline Unit B & $\begin{array}{l}\text { Pumice- } \\
\text { fall }\end{array}$ & 2.4 to $0.8 \mathrm{~m}$ & Nonwelded & $\begin{array}{l}\text { Clast supported; } 80 \text { pct pumice clasts include dom- } \\
\text { inant brown and altered clasts, subordinate } \\
\text { light-gray and vitric clasts; ash layer } 1 .\end{array}$ & Massive & $\begin{array}{l}\text { Argillic alteration } \\
\text { and oxidation of } \\
\text { pumice ciasts }\end{array}$ & $\begin{array}{l}0.36 \text { to } 0.65 \\
\quad(\text { mean } 0.51)\end{array}$ & $\begin{array}{l}0.99 \text { to } 1.49 \\
\quad(\text { mean } 1.16)\end{array}$ \\
\hline Unit A & $\begin{array}{l}\text { Pumice- } \\
\text { fall }\end{array}$ & $\begin{array}{l}2.8 \text { to } 1.6 \mathrm{~m} \\
\text { (moderately } \\
\text { welded part } \\
1.8 \text { to } 0 \mathrm{~m} \text { ) }\end{array}$ & $\begin{array}{l}\text { Nonwelded } \\
\text { at top to } \\
\text { moderate at } \\
\text { base of unit }\end{array}$ & $\begin{array}{l}\text { Moderate brown to light gray downward; pumi- } \\
\text { ceous; pumice clasts coarsen upward; lithic- } \\
\text { clast content decreases downward from } 10-25 \\
\text { to } 5-7 \text { pct; locally, overlies moderately welded } \\
\text { pyroclastic-flow deposit. }\end{array}$ & Massive & $\begin{array}{l}\text { Local minor alter- } \\
\text { ation of pumice } \\
\text { clasts }\end{array}$ & $\begin{array}{l}\text { Non- to partially } \\
\text { welded: } 0.25 \\
\text { to } 0.52 \text { (mean } \\
0.38 \text { ); moder- } \\
\text { ately welded: } \\
0.03 \text { to } 0.30 \\
\text { (mean } 0.19 \text { ) }\end{array}$ & $\begin{array}{l}\text { Non- to partially } \\
\text { welded: } 1.06 \\
\text { to } 1.74 \text { (mean } \\
1.42 \text { ); moder- } \\
\text { ately welded: } \\
1.58 \text { to } 2.38 \\
\text { (mean } 1.91 \text { ) }\end{array}$ \\
\hline
\end{tabular}




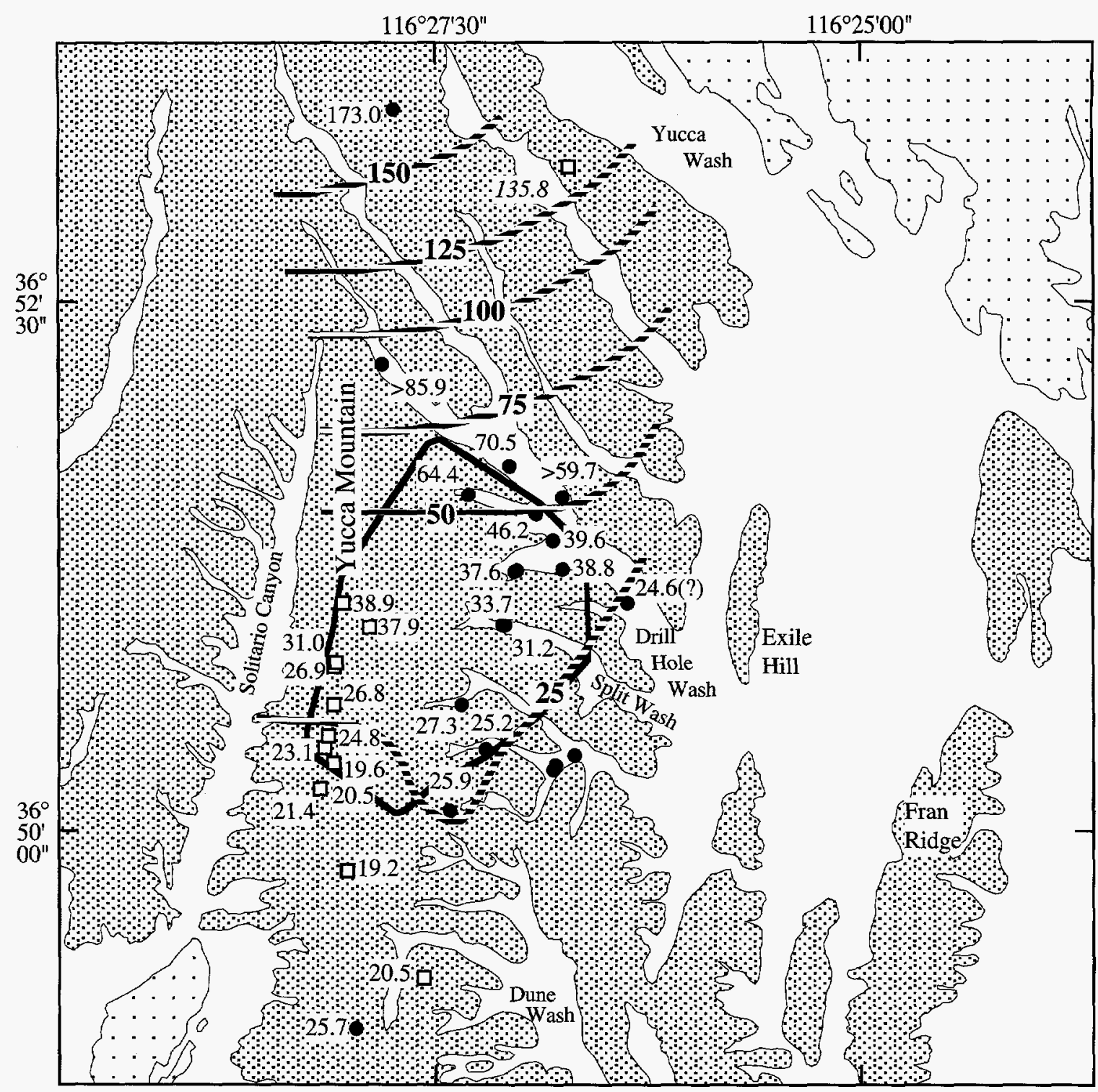

\section{EXPLANATTON}

Boundary of potential repository area

- Alluvium and colluvium

- Outcrop of Paintbrush Group tuffaceous rocks

$\because$ - Outcrop of other Miocene volcanic rocks

' " I 50, , Contour of thickness (m) of the PTn unit

39.6

- Cumulative thickness (m) of PTn unit in borehole

26.8

- Cumulative thickness (m) of PTn unit in measured section

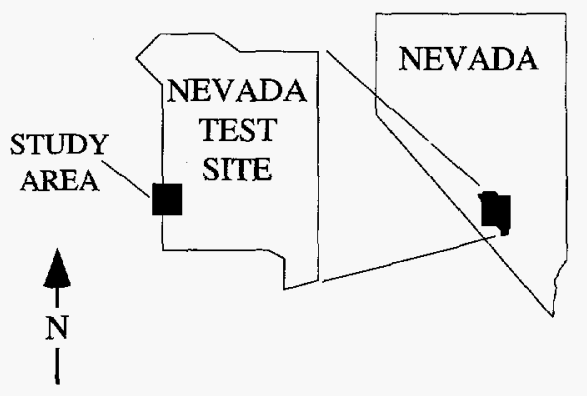

135.8

- Cumulative thickness from two adjacent measured sections

Figure 4. Isochore map showing the composite apparent thickness of the Paintbrush Tuff nonwelded hydrologic unit. Values for boreholes are drilled thickness uncorrected for deviation from vertical. 


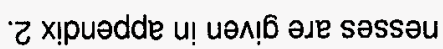

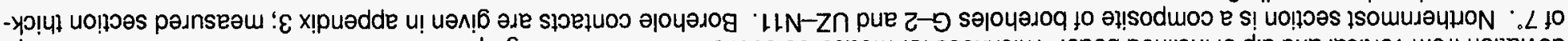

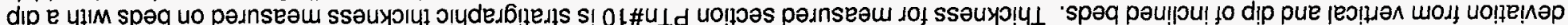

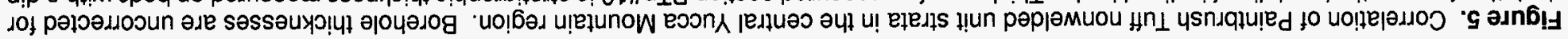

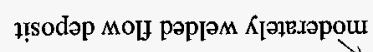

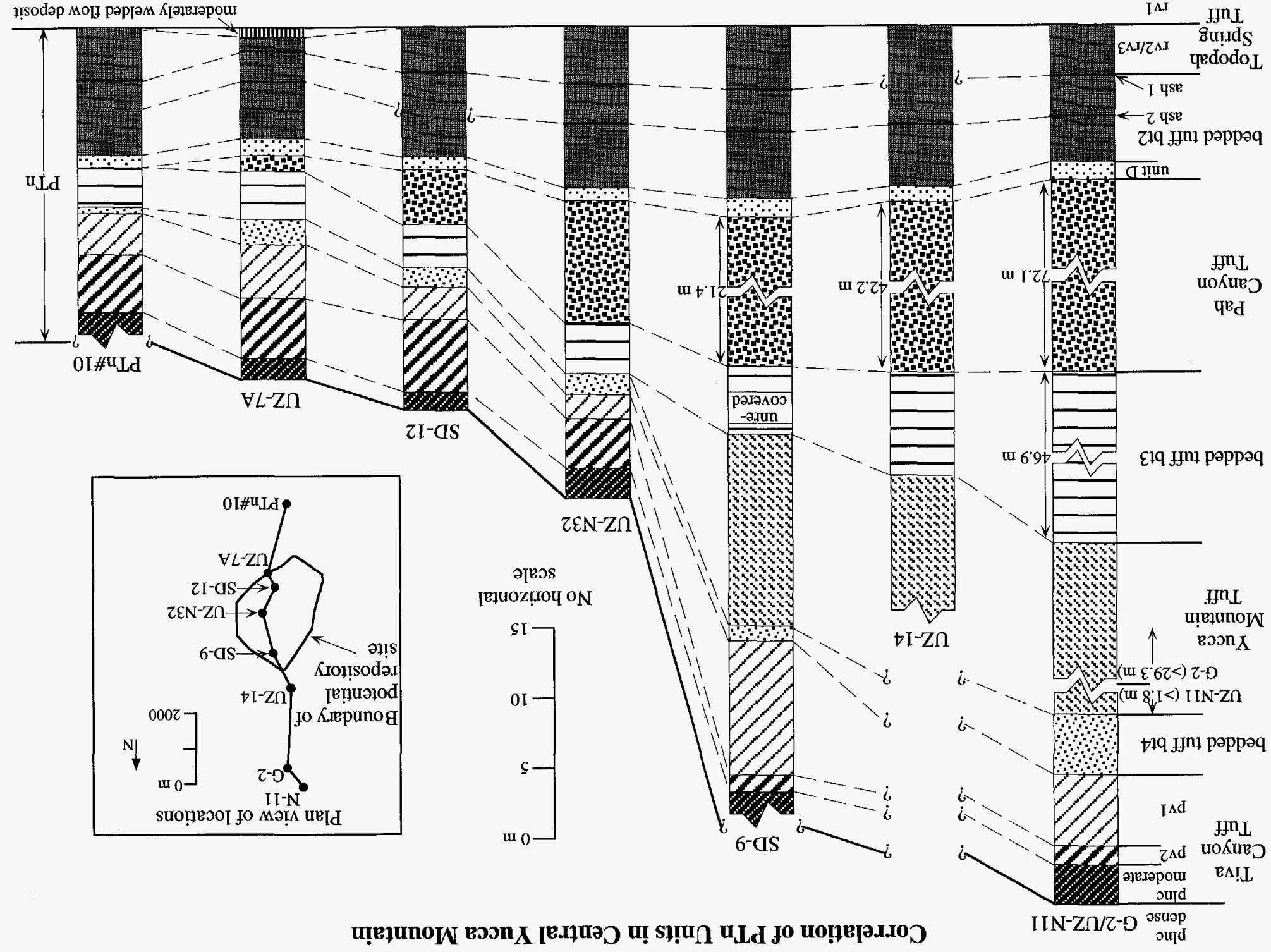




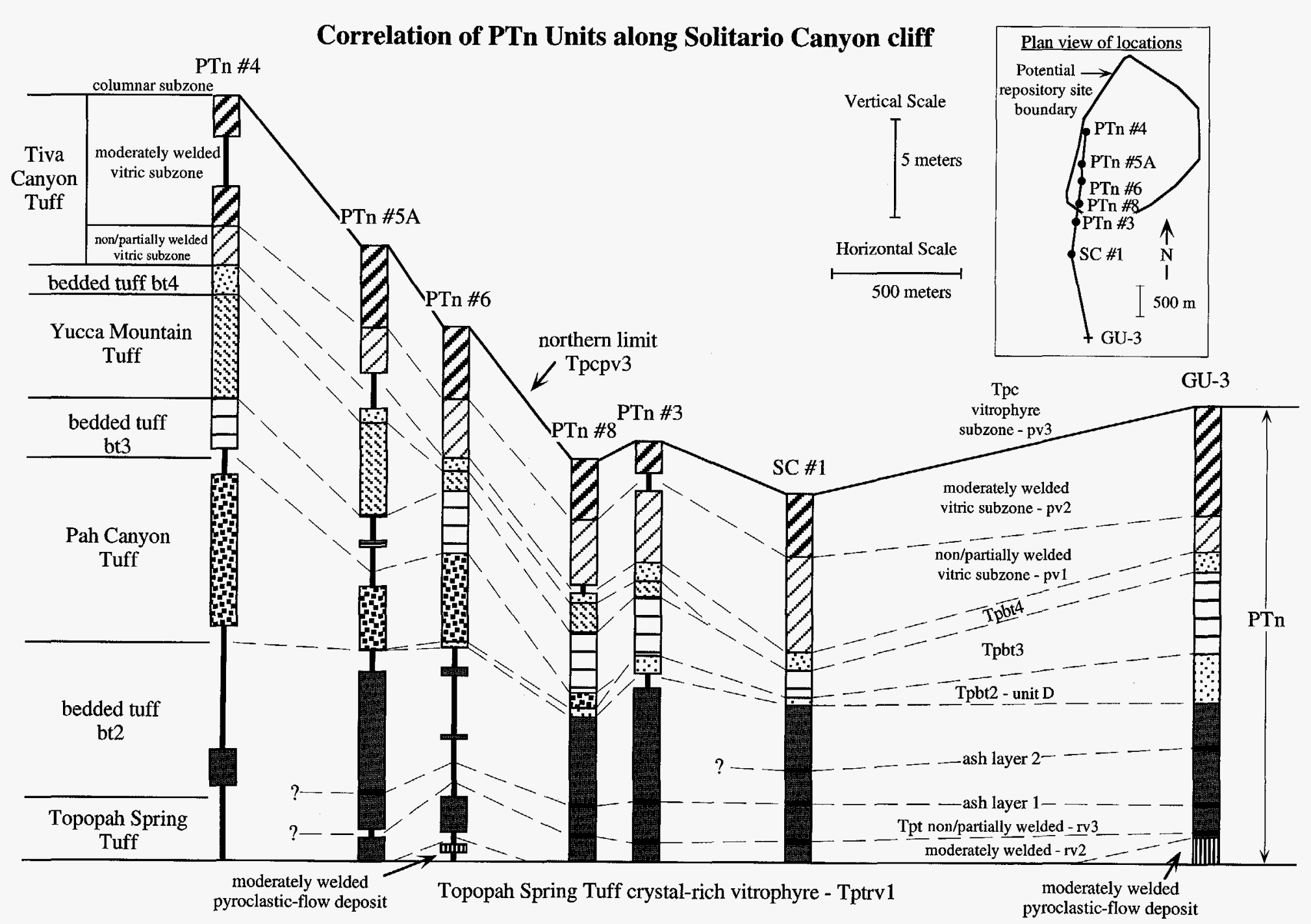

Figure 6. Correlation of Paintbrush Tuff nonwelded hydrologic-unit strata along Solitario Canyon cliff. Measured sections plot stratigraphic thicknesses that are uncorrected for the dip of beds inclined from $5^{\circ}$ to $8^{\circ}$. Thicknesses for borehole GU 3 are uncorrected for deviation from vertical and dip of inclined beds. Solid vertical bars depict covered parts of the section. Measured section thicknesses are given in appendix 2 ; borehole contacts are given in appendix 3 . 
Alteration of the PTn units can be divided into three general categories. Alteration associated with syn- or post-depositional surficial processes occurs on a regional scale and is confined to a specific bed or zone. Examples include the incipient paleosol formed at the top of pre-Tiva Canyon Tuff bedded tuff unit B (Tpbt4B; fig. 3 and table 3 ) and the weathered or reworked pumice-fall deposit of the pre-Yucca Mountain Tuff bedded tuffs unit B (Tpbt3B; fig. 3 and table 3 ). Alteration of these units is ubiquitous, although the paleosol of unit Tpbt4B is variably developed.

Alteration related to post-depositional welding and cooling of pyroclastic deposits occurs on a regional to local scale and is confined to a specific bed or zone. Examples include the argillically altered zones that occur beneath the devitrified interiors of the Tiva Canyon (Tpc), Yucca Mountain (Tpy), and Pah Canyon Tuffs (Tpp), the pervasive alteration of pre-Pah Canyon Tuff bedded tuff unit B (Tpbt2B; fig. 3 and table 3 ), and the reddish, clay-rich horizon developed on the top of the pre-Pah Canyon Tuff bedded tuff unit $\mathrm{C}$ (Tpbt2C; fig. 3 and table 3 ). Whereas argillization of glassy Tpc, Tpy, and Tpp material is most likely related to cooling of these pyroclastic-flow deposits, alteration of units Tpbt $2 \mathrm{C}$ and $\mathrm{Tpbt} 2 \mathrm{~B}$ is probably related to cooling and degassing of the underlying Topopah Spring Tuff pyroclastic-flow material. The reddish clay alteration at the top of unit $\mathrm{Tpbt} 2 \mathrm{C}$, which varies markedly in intensity and lateral continuity (it is absent locally), may be related to localized fumarolic or hydrothermal alteration. Exposures of Tpbt2B along Solitario Canyon cliff show that alteration of this unit, although more widespread, also varies in intensity and vertical extent.

Alteration related to faulting is local and not confined to specific beds or zones. Examples include the zeolitization and silicification of the Pah Canyon Tuff and pre-Pah Canyon Tuff bedded tuffs in borehole NRG \#4 and alteration of these units and overlying PTn strata in borehole NRG \#2B.

Three intervals within the PTn unit contain evidence for reworking and redeposition of primary pyroclastic material on a local to regional scale. Largescale crossbedding and abrupt thickness variations within unit Tpbt4B (fig. 3 and table 3 ) are consistent with local eolian reworking of primary pumiceous fallout. A variety of features are consistent with disruption of the post-Yucca Mountain Tuff paleosurface by a turbulent, high-velocity process, perhaps a volcanic blast or surge. These include locally truncated beds in the upper part of Tpbt3, angular blocks of Yucca Mountain Tuff that are dislocated and incorporated in overlying material along the Tpy-Tpbt 4 contact, planar to low-angle cross laminations in the lower part of unit Tpbt4B, and a brownish tuff that contains a mix of lithologies, including clasts of a distinctive poorly vesicular glass, which locally occurs at the Tpy-Tpbt4 contact. Pre-Pah Canyon Tuff bedded tuff unit $D$ (Tpbt2D, fig. 3 and table 3 ) is a cross-laminated, pebbly sandstone at measured section PTn\#5, which suggests a localized component of fluvial reworking in its formation.

\section{Crystal-Poor Tiva Canyon Tuff (Tpcp)}

The interval from the base of the Tiva Canyon Tuff upward to the transition from moderate to dense welding in the crystal-poor member of the formation composes the upper part of the PTn hydrologic unit. Within the lower Tiva Canyon Tuff, the transition from moderate to dense welding occurs at the base of the densely welded subzone of the crystal-poor vitric zone (Tpcpv3) or, if Tpcpv3 is not present, within the columnar subzone of the crystal-poor lower nonlithophysal zone (Tpcplnc) (Buesch, Spengler, and others, 1996). PTn units in the Tiva Canyon Tuff include the non- to partially welded and moderately welded subzones of the crystal-poor vitric zone (Tpcpv1 and Tpcpv2, respectively) and, locally, the moderately welded basal portion of Tpcplnc. These units reflect an upward increase in the degree of welding (Buesch, Spengler, and others, 1996).

A pyroclastic-flow boundary locally is visible in the crystal-poor vitric zone of the Tiva Canyon Tuff (Rautman and others, 1993; Istok and others, 1994). The flow boundary is marked by a crystal- and shardrich horizon approximately $5 \mathrm{~cm}$ thick, with welldeveloped horizontal laminations or cross laminations (fig. 7) that separates a lower pumice-rich flow unit from an overlying pumice-poor flow unit.

The lower flow unit has a variable thickness (see Istok and others, 1994). In outcrops at Isolation Ridge, (measured section PTn\#1, fig. 1), the flow boundary occurs within Tpcpvl, approximately $1.4 \mathrm{~m}$ above the base of the formation. Along the eastern side of 


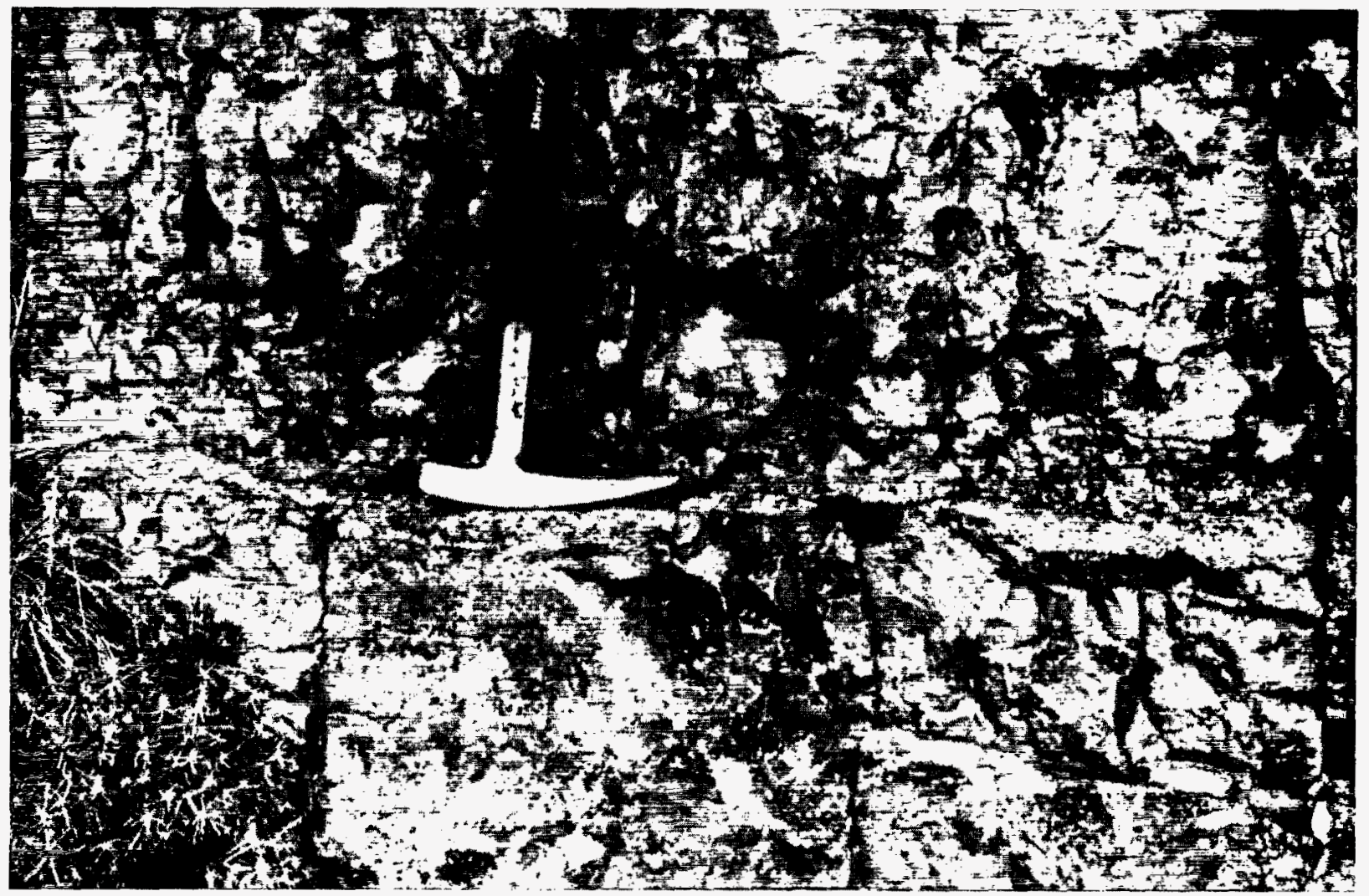

Figure 7. Photograph of pyroclastic-flow boundary in the moderately welded subzone of the Tiva Canyon Tuff crystalpoor vitric zone taken along Solitario Canyon cliff, near measured section PTn\#8. The flow-unit boundary occurs at the hammerhead and is marked by a crystal-rich horizon with parallel laminae. Note fiamme in the upper flow unit.

Solitario Canyon (measured section PTn\#3, fig. 1), the flow boundary occurs within Tpcpv2, approximately $4.8 \mathrm{~m}$ above the base of the formation. In core from borehole UZ-N11 (fig. 1), a dramatic upward decrease in pumice content occurs approximately $2.7 \mathrm{~m}$ above the base of the formation. Multiple swarms of pumice clasts locally are visible in the base of Tpcplnc, suggesting that additional flow boundaries may be present near the base of the Tiva Canyon Tuff.

Unit and contact descriptions are given below for units of the Tiva Canyon Tuff that are included in the PTn hydrologic unit. These descriptions were developed from observations of core recovered from boreholes UZ-N11, NRG-7/7A, SD-9, NRG-6, UZ-N31, UZ-N32, and SD-12 (fig. 1). Additional observations of core from older boreholes and of exposures at nine measured sections along the east side of Solitario Canyon, near Yucca Wash, and in Abandoned Wash (fig. 1) were used to clarify stratigraphic relations and lateral variability of these units.

\section{Generalized Unit and Contact Descriptions}

\section{Crystal-Poor Lower Nonlithophysal Zone, Columnar Subzone (Tpcplnc)}

The lowest part of the columnar subzone of the crystal-poor nonlithophysal zone is included as part of the PTn hydrologic unit where the crystal-poor vitrophyre (Tpcpv3) is absent. This unit is moderately welded and devitrified. The matrix is grayish orangepink or grayish orange with light-brown to orangebrown devitrified shards. Deformed pumice clasts ( 1 to 7 percent) are typically light to moderate brown and devitrified or vapor-phase altered, or locally black and vitric. Phenocrysts ( 2 to 3 percent) are mostly feldspar.

The upper and lower contacts of the unit are gradational over a few decimeters. The lower contact is defined by the upward transition from vitric to devitrified matrix. The upper contact is defined by the upward loss of visible matrix porosity that accompanies the change from moderate to dense welding.

16 Stratigraphic Relations and Hydrologic Properties of the Paintbrush Tuff Nonwelded (PTn) Hydrologic Unit, Yucca Mountain, Nevada 


\section{Crystal-Poor Vitric Zone, Moderately Weided Subzone (Tpcpv2)}

This unit is a moderately welded, vitric, pyroclastic-flow deposit. The matrix is composed of vitric shards enclosed in devitrified or vitric ash. The shards are slightly deformed at the base of the unit and moderately deformed at the upper contact. Matrix colors include shades of grayish orange and light brown or rarely shades of gray. Shards are dominantly black or grayish orange to light brown, with common, deformed bubble-wall textures. Lithic clasts ( 1 to 2 percent), typically smaller than $10 \mathrm{~mm}$, are mostly of devitrified volcanic rock. Pumice clasts ( 2 to 10 percent) are dominantly grayish pink or grayish orange-pink and altered (argillic?), or rarely white or grayish black and vitric. Most have diameters between 5 and $15 \mathrm{~mm}$. Phenocrysts ( 1 to 3 percent) are mostly feldspar with rare biotite (locally oxidized). The moderately welded crystal-poor vitric subzone commonly exhibits argillic (?) alteration that varies in intensity laterally. This alteration, characterized by yellow to orange discoloration, typically extends upward into the base of the moderately welded columnar subzone and locally extends downward into the non- to partially welded vitric subzone. An excellent example of this altered interval is preserved in core from borehole UZ-N11.

The lower and upper contacts of the unit are gradational over a few decimeters. Rock fracture is the primary criterion for defining the Tpcpv2-Tpcpvl contact; whereas the rock in Tpcpv 2 breaks across shard boundaries, that in Tpcpv1 breaks around shard boundaries. Where the crystal-poor vitrophyre (Tpcpv3) is present, the upper contact of Tpcpv 2 is marked by the loss of visible matrix porosity that accompanies the change from moderate to dense welding. Where Tpcpv3 is absent, the upper contact is marked by the change from vitric to devitrified matrix.

\section{Crystal-Poor Vitric Zone, Non- to Partially Welded Subzone (Tpcpv1)}

This unit is a vitric, non- to partially welded, pyroclastic-flow deposit. The matrix is composed of vitric shards and devitrified or vitric ash. Matrix colors typically grade downward from grayish orange, dark yellowish orange, or gray to very light gray, or pinkish gray. Shards, dominantly black or light brown with common bubble-wall textures, are slightly deformed near the top of the unit and nondeformed at the base. Shards increasingly stand out in relief on a fresh surface as welding decreases downward. Lithic clasts ( 1 to 2 percent), which include medium gray or very light-gray and subordinate pale yellowish-brown or grayish-red devitrified volcanic rock, are typically less than $10 \mathrm{~mm}$ diameter. Pumice clasts typically compose 2 to 12 percent but may be as high as 25 to 30 percent at the tops of flow units. Pumice clasts are dominantly altered (argillic?) and moderate orange-pink or grayish orange-pink, and subordinately vitric and pinkish gray, pale red, or very pale orange. Pumice-clast sizes are variable. Most clasts are smaller than $10 \mathrm{~mm}$; however, some clasts near the base of the unit exceed $80 \mathrm{~mm}$ in diameter. Phenocrysts ( 1 to 3 percent) are mostly feldspar with rare biotite (locally oxidized).

The base of the formation typically is marked by a coarse ground layer that is interpreted as a surge or lag deposit. The ground layer generally appears as a reversely graded or crossbedded, pumiceous deposit. Pinkish-gray, vitric pumice clasts ( 30 to 40 percent) typically have diameters of 5 to $15 \mathrm{~mm}$ that grade upward to 10 to $30 \mathrm{~mm}$ (rarely up to $50 \mathrm{~mm}$ ). The ground layer contains approximately 1 percent lithic clasts and 1 to 2 percent crystals in a gray, vitric matrix. The lower contact of this unit, and the formation, is sharp, with the ground layer overlying the reddishpink, pumiceous deposit at the top of the pre-Tiva Canyon Tuff bedded tuffs (Tpbt4).

\section{Unit Distribution and Thickness}

The Tiva Canyon Tuff is interpreted to have erupted from a source within the Claim Canyon caldera, a few kilometers to the north of Yucca Mountain (Byers and others, 1976). The Tiva Canyon Tuff interval included within the PTn hydrologic unit occurs throughout the Yucca Mountain area (for example, Buesch, Spengler, and others, 1996; Geslin and others, 1995). The thickness of the moderately welded interval in Tpcplnc is greatest, approximately $3 \mathrm{~m}$, in boreholes in the eastern and northern part of Yucca Mountain; the interval pinches out to the south where the crystal-poor vitrophyre is present (appendixes 2 and 3; fig. 1). A maximum thickness of Tpcpv2 of $6.2 \mathrm{~m}$ was observed in core from borehole GU-3. A minimum thickness of Tpcpv2 of $0.5 \pm 0.2 \mathrm{~m}$ was observed in core from borehole UZ \#16; however, this core is highly altered and the loss of vitric material at 
the upper contact may reflect low-temperature alteration and not high-temperature devitrification. Elsewhere, a minimum thickness of Tpcpv 2 of $1.2 \mathrm{~m}$ was observed in core from borehole SD-9. A maximum thickness of Tpcpv 1 of $9.6 \mathrm{~m}$ was observed in core from borehole SD-9, and a minimum thickness of $1.2 \mathrm{~m}$ was observed in core from borehole UZ-N31.

An isochore map of the combined thicknesses of Tpcpv1 and Tpcpv2 in the Yucca Mountain area by Buesch, Nelson, and others (in press) shows a variable combined thickness that is generally greatest in the southern and western parts of the area. An isochore map of the combined thicknesses of Tpcpvl and Tpcpv2, produced from data collected in this study (a more limited study area, fig. 8), suggests that the combined thicknesses of Tpcpv 2 and Tpcpv1 is greatest in the northern part of the potential repository area and is least in the Split Wash area in the eastern part of the potential repository.

Units of the lower part of the Tiva Canyon Tuff are correlated through a series of stratigraphic sections measured along the eastern side of Solitario Canyon (fig. 9). Figure 9 illustrates that Tpcpvl thickens to the south, is thinnest in the middle of the transect (in the area of potential repository), and has a variable thickness to the north. The thickness of the moderately welded interval in the Tiva Canyon Tuff (Tpcpv2 and the moderately welded part of Tpcplnc) also varies along Solitario Canyon cliff, being thickest at measured sections PTn\#11 and SC\#2. The combined thicknesses of the non- to partially and moderately welded intervals is generally least in the middle of the transect, in the area of the potential repository.

\section{Pre-Tiva Canyon Tuff Bedded Tuffs (Tpbt4)}

The pre-Tiva Canyon bedded tuffs (Tpbt4) are thin, nonwelded, laterally continuous deposits found throughout the study area. This study divides Tpbt4 into two informal units; a brown, lithic-rich, pyroclastic-flow deposit (unit A) overlain by a white to light-gray, well-sorted, pumiceous deposit (unit B). Unit B, as discussed below, is interpreted to be a pumice-fall deposit that overlies a basal surge or blast deposit. Unit B also has features suggesting local eolian (?) reworking and the development of an incipient paleosol (?).
Unit and contact descriptions given below for Tpbt 4 were developed from observations of core recovered from boreholes NRG-7/7A, NRG-6, UZ-N11 and UZ\#16. Additional observations of core from several older boreholes and of exposures at nine measured sections along the east side of Solitario Canyon and in Abandoned Wash (fig. 1; appendix 2) were used to clarify stratigraphic relations and lateral variations. Many key observations for unit $\mathrm{B}$ were made at measured section PTn\#11 (figs. 1 and 10; appendix 2).

\section{Generalized Unit and Contact Descriptions}

\section{Unit B}

Unit B is a well-sorted, light-gray, pumiceous deposit. The unit exhibits abrupt lateral changes in thickness; in outcrop it thickens from $50 \mathrm{~cm}$ to more than $2 \mathrm{~m}$ within a few tens of meters laterally. Unit B is composed primarily of vitric pumice clasts $(90$ to 95 percent) that are white to grayish orange-pink and 1 to $3 \mathrm{~mm}$ in diameter; pale-red to medium light-gray devitrified lithic clasts ( 2 to 5 percent); and phenocrysts ( 2 to 3 percent) of feldspar and rare hornblende. The upper and lower contacts of unit B are sharp and depositional.

The lowermost 5 to $10 \mathrm{~cm}$ of unit B contains parallel horizontal laminae that may have been deposited by a pyroclastic surge or blast (fig. 10). At measured section PTn\#11, these laminae pinch and swell around angular blocks eroded from the underlying Yucca Mountain Tuff (fig. 10). Pumice clasts are notably coarser ( 2 to $10 \mathrm{~mm}$ ) on one side of the blocks and may have been deposited in "eddies" created on the lee side if the blocks during high flow regime transport and deposition (fig. 10). Additional description of this interval is provided in the section that describes the upper contact of the Yucca Mountain Tuff.

Where unit B is thin, a 50- to $60-\mathrm{cm}$-thick, structureless fallout deposit overlies the laminated horizon. A few faint horizontal laminae locally occur within the massive interval. The fallout deposit grades upward into a distinctive, reddish-orange incipient paleosol (?) that forms 1 to 2 percent of the rock and that occurs either as matrix and/or a coating on grains. The incipient paleosol (?) is locally absent or poorly developed. 


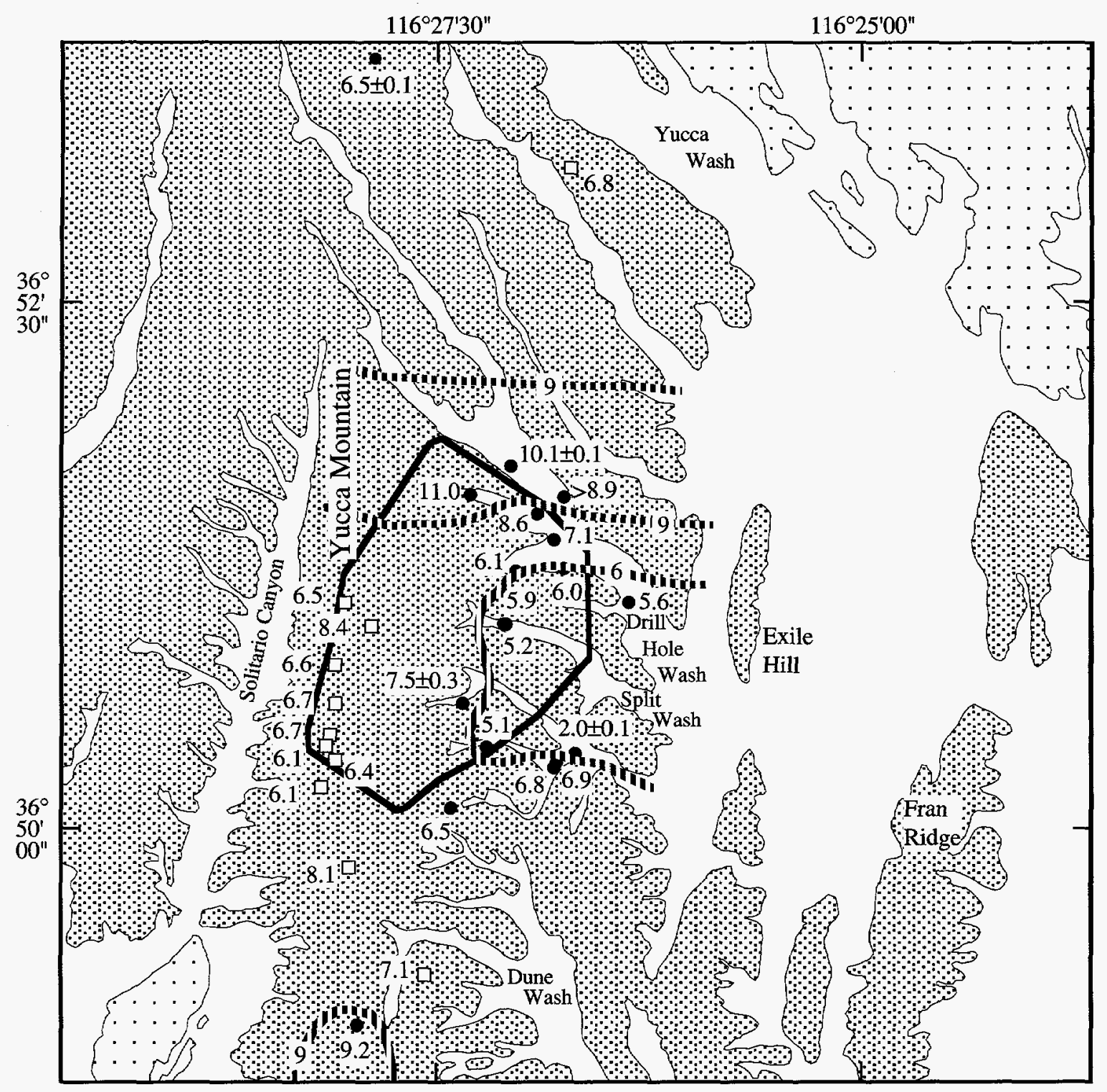

\section{EXPLANATION}

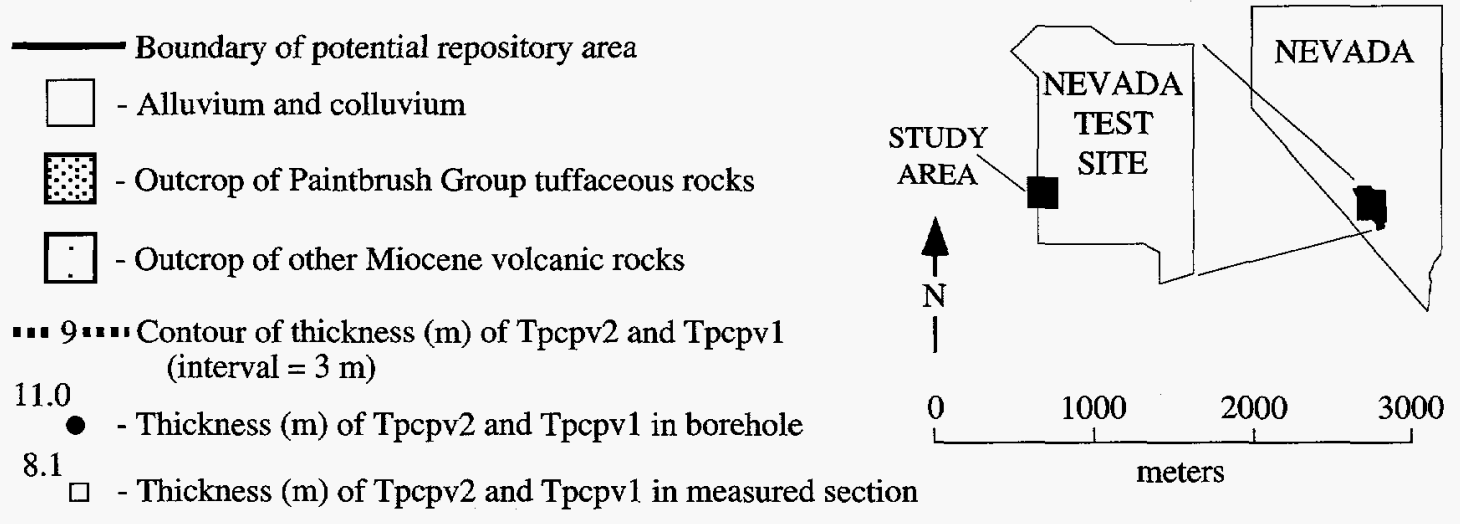

Figure 8. Isochore map showing apparent thickness of combined non- to partially welded (Tpcpv1) and moderately welded (Tpcpv2) subzones of the Tiva Canyon Tuff crystal-poor vitric zone. Values for boreholes are drilled thicknesses uncorrected for deviation from vertical, and values for measured sections are vertical thicknesses. 


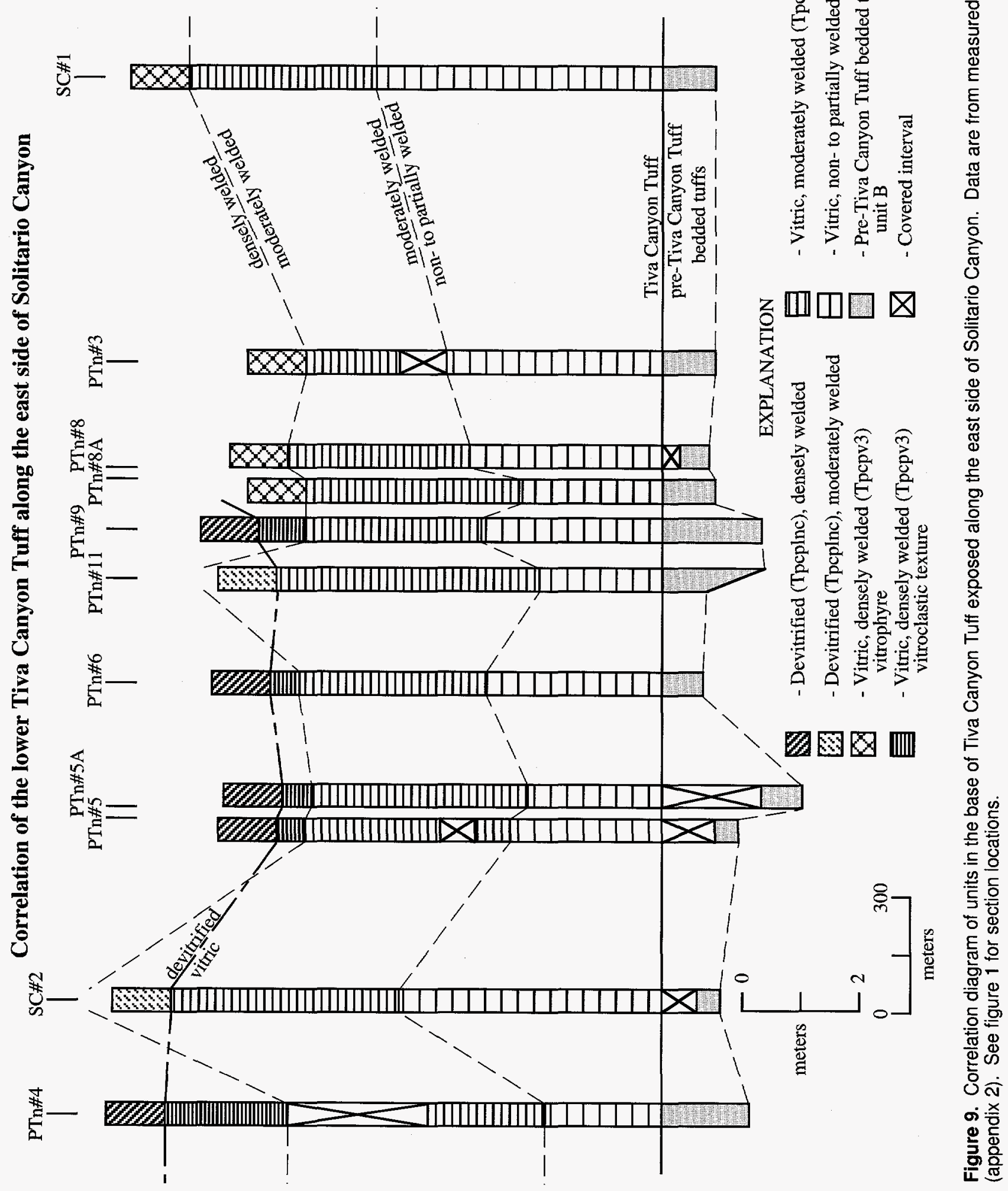

20 Stratigraphic Relations and Hydrologic Properties of the Paintbrush Tuff Nonwelded (PTn) Hydrologic Unit, Yucca Mountain, Nevada 

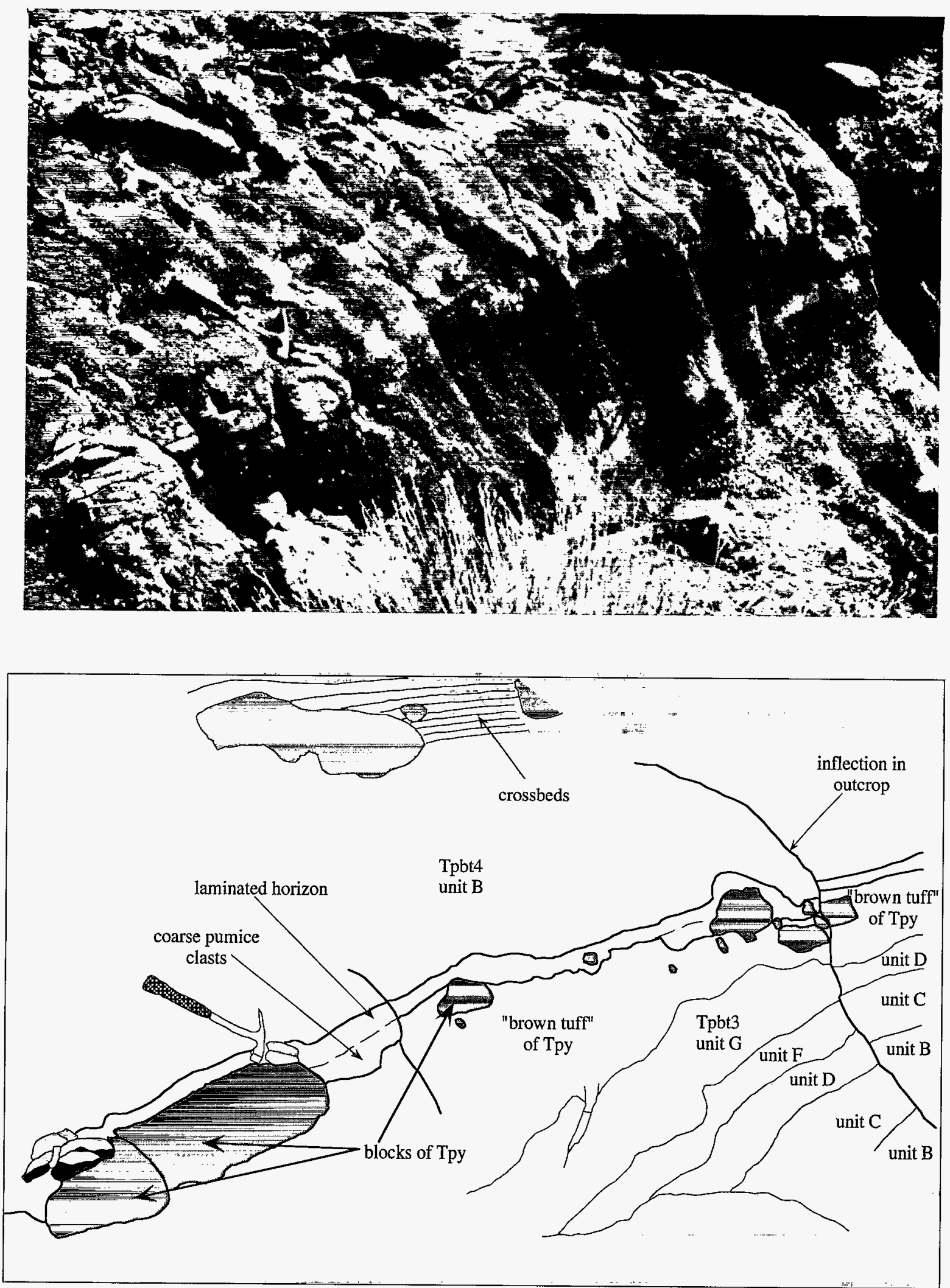

Figure 10. Photograph and sketch of an outcrop at measured section PTn\#11 (fig. 1; appendix 2). This outcrop contains the abrupt thickness change, crossbedding, and basal laminae characteristic of the pre-Tiva Canyon Tuff bedded tuffs (Tpbt4), an underlying interval of brown tuff that contains blocks of lithified Yucca Mountain Tuff (Tpy), and truncated bedding in the top of the pre-Yucca Mountain Tuff bedded tuffs (Tpbt3). Geologic hammer shows scale. 
In areas where unit $B$ is thicker, the fallout can approach $1 \mathrm{~m}$ thickness and be overlain by 0.5 to $1.5 \mathrm{~m}$ of crossbedded, pumiceous tuff that may be an eolian deposit (fig. 11). Excellent examples of crossbedding in unit B can be seen at measured section PTn\#11, in outcrops immediately south of measured section SC\#1 and slightly south of measured section PTn\#9 (fig. 11), and in core from borehole UZ-N11. At measured section PTn\#11, the crossbeds are oriented $40^{\circ}$ $(\mathrm{N} 40 \mathrm{~W}), 35^{\circ}(\mathrm{E})$, appear to pinch and swell, and appear to have alternating light- and dark-gray laminae. Typically, the cross laminae are overlain by 20 to $40 \mathrm{~cm}$ of massive tuff with a reddish-orange incipient paleosol (?) developed on its upper surface (fig. 11).

\section{Unit A}

Unit A is a brown, nonwelded, pyroclastic-flow deposit. The content of matrix, pumice clasts, and lithic clasts in unit A varies by location. The matrix (ranging from 30 to 70 percent) contains abundant dark yellowish-orange to black glass shards with bubblewall textures. White, vitric pumice clasts (ranging from 2 to 25 percent) have diameters between 7 and $14 \mathrm{~mm}$. Lithic clasts (ranging from 10 to 35 percent) are mostly smaller than $5 \mathrm{~mm}$ and include medium light-gray to pale-red devitrified lava, black obsidian, and light-gray perlitic glass. Unit A is crystal poor (less than 1 percent), with crystals of feldspar, pyroxene, and rare biotite.

\section{Unit Distribution and Thickness}

Pre-Tiva Canyon Tuff bedded tuffs were observed in core from all boreholes and measured sections examined in this study. Byers and others (1976) inferred the source of these tuffs to be within the Claim Canyon caldera, north of Yucca Mountain. The cumulative thickness of Tpbt 4 reaches a maximum of $4.3 \mathrm{~m}$ in borehole UZ-N11 and a minimum of $0.3 \mathrm{~m}$ in borehole UZ-N54 (fig. 1).

Unit B occurs in all locations except in core from borehole UZ-N54. The unit has a maximum observed thickness of $4.3 \mathrm{~m}$ in core from borehole UZ-N11. This study and previous studies (for example, Rautman and others, 1993) note that abrupt lateral thickness variations characterize unit $B$. Importantly, isochore maps constructed at site scale of unit $B$ and of the combined thicknesses of units $A$ and $B$ do not depict the abrupt thickness changes that occur on the scale of meters.
Unit $A$ is thin and discontinuous in the study area. The unit was observed in core from nine boreholes but has not been found in outcrop. A maximum thickness of $1.1 \mathrm{~m}$ occurs in core from borehole UZ-7A. Unit A is limited to the subsurface on the east side of Yucca Mountain where it apparently forms two west-directed lobes in the middle of the potential repository site (fig. 12). The distribution of unit A suggests that its source may have been to the east of Yucca Mountain, not from the Claim Canyon caldera.

\section{Features of Reworking}

Unit B of the pre-Tiva Canyon Tuff bedded tuffs contains two features created by post-depositional surficial processes: large-scale crossbedding (fig. 11), present in areas where the unit is thick, and the reddishorange, relatively matrix-rich top of the unit. The interpretation of large-scale crossbedding as evidence of eolian reworking contrasts the conclusion of Diehl and Chornack (1990) that there has been no reworking of the nonwelded bedded tuffs at Yucca Mountain. The form of crossbedding observed in unit B is similar to crossbedding observed in traverse sections of eolian deposits in barchanoid ridges (Brookfield, 1984). McKee (1979), summarizing a study of modern barchan dunes and barchanoid ridges, notes that largescale crossbeds that dip $30^{\circ}$ to $34^{\circ}$, with low-angle bounding surfaces (less than $8^{\circ}$ ), are indicative of these deposits. The crossbedding in unit B at measured section PTn\#11 dips $35^{\circ}$, and the bounding surface shown in figure 11 appears to be low angle.

Christiansen and others (1977) interpreted unit B as the basal pumice-fall deposit of the Tiva Canyon Tuff, implying that the contact between unit B and the overlying pyroclastic-flow deposits does not represent a significant depositional hiatus. This interpretation apparently precludes development of an incipient paleosol and indirectly implies that the red horizon is a "baked zone" related to the overlying Tiva Canyon Tuff. However, it is more likely that the red color in the top of unit B is from oxidation of ferruginous clay washed in during rainstorms (Diehl and Chornack, 1990) than from iron in a pyroclastic deposit that is poor in total iron and iron-bearing minerals such as biotite and hornblende. Diehl and Chornack (1990) refer to iron-stained horizons, like the one at the top of unit B, as "weathered zones," and the term "incipient paleosol" is used here in the same sense. 

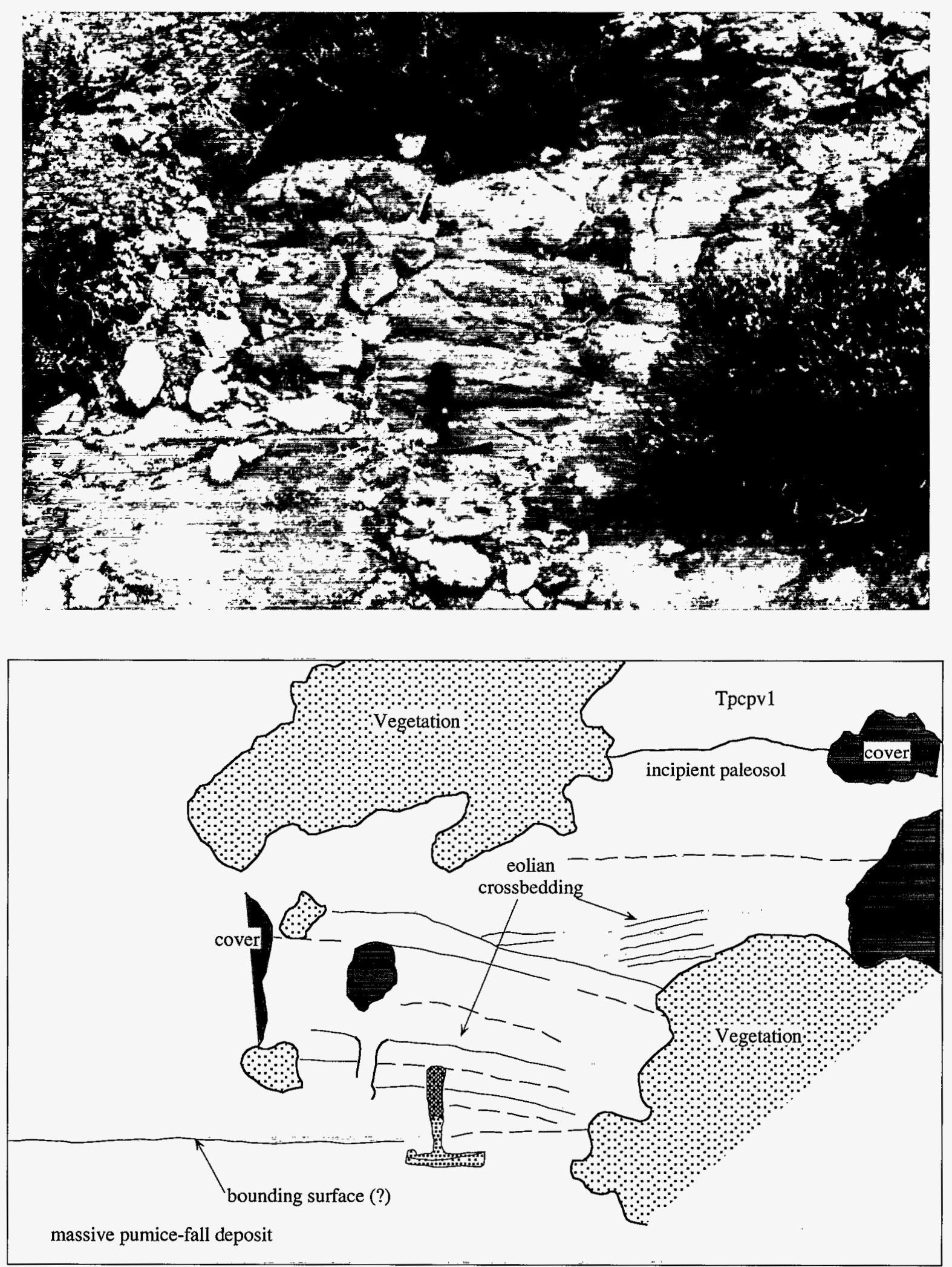

Figure 11. Photograph and sketch of pre-Tiva Canyon Tuff bedded tuffs (Tpbt4) in an outcrop near measured section PTn\#9 (fig. 1). This outcrop contains an excellent example of the large-scale crossbedding in unit B. The incipient paleosol (darker coloration) characteristic of unit B can be seen in the upper right of the photograph and sketch. 


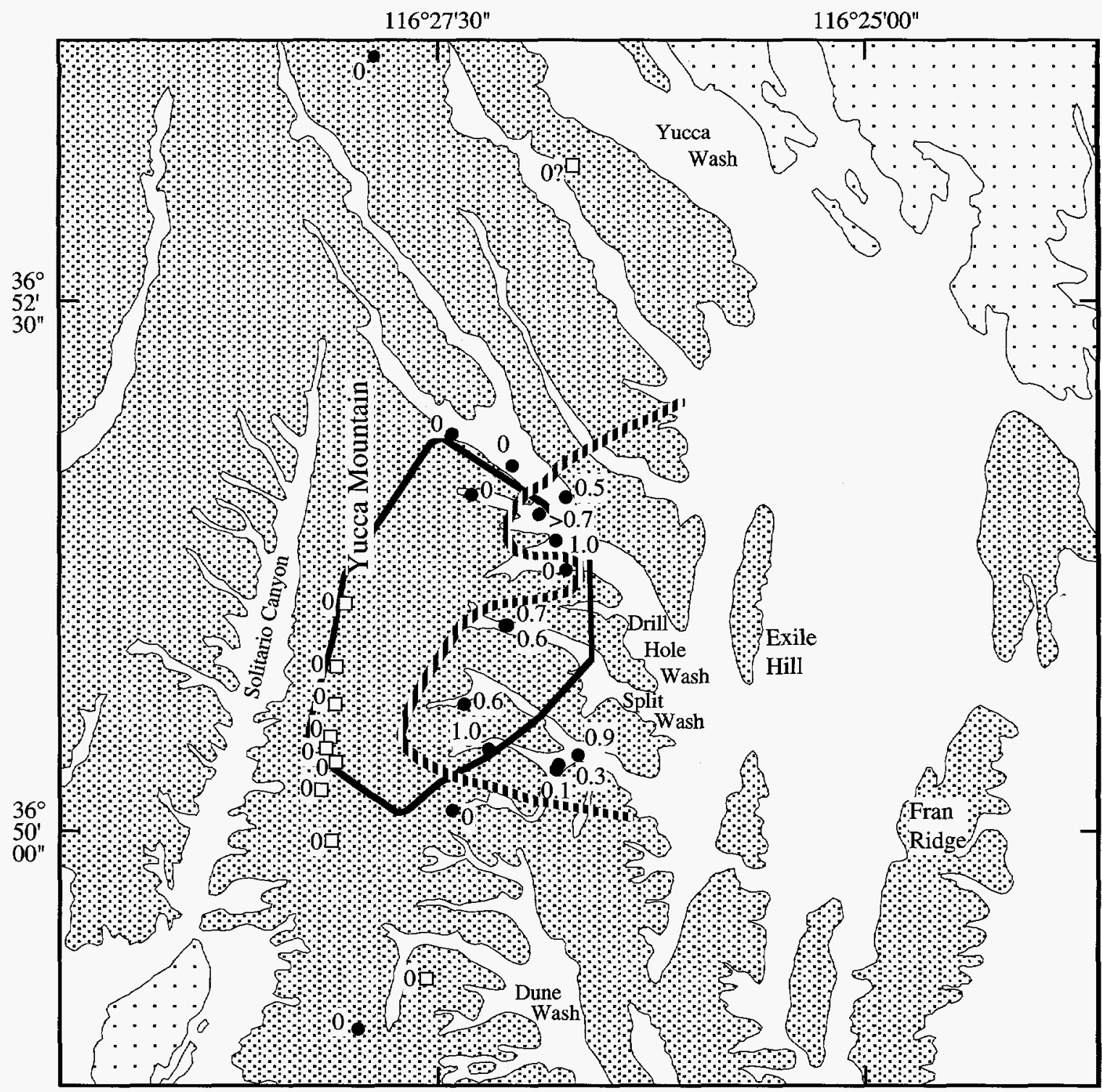

\section{EXPLANATION}

Boundary of potential repository area

$\square$ - Alluvium and colluvium
- Outcrop of Paintbrush Group
tuffaceous rocks
- Outcrop of other Miocene
volcanic rocks

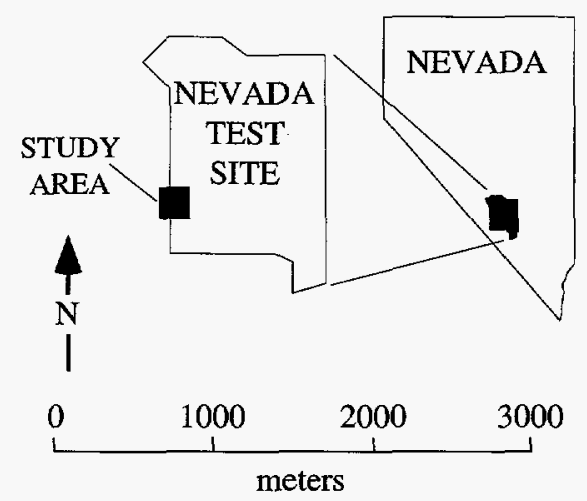

Figure 12. Isochore map showing apparent thickness distribution of pre-Tiva Canyon Tuff bedded tuff (Tpbt4) unit A. Values for boreholes are drilled thicknesses uncorrected for deviation from vertical. 


\section{Yucca Mountain Tuff (Tpy)}

Seven boreholes drilled since 1991 contain complete stratigraphic sequences of vitric to variably altered Yucca Mountain Tuff (Tpy). The formation is nonwelded in boreholes UZ-N53, UZ-N54, $\mathrm{UZ}-\mathrm{N} 55, \mathrm{UZ} \# 16$, and NRG \#2B and non- to partially welded in boreholes SD-9 and NRG-7/7A (fig. 1). Boreholes USW UZ-N11, UZ-N33, and UZ-N34 (fig. 1) preserve partial stratigraphic sequences of Tpy that vary downward from vitric and nonwelded to devitrified and partially to moderately welded. These cores contain the contact between the Yucca Mountain Tuff and overlying units of pre-Tiva Canyon Tuff bedded tuffs (Tpbt4) or Quaternary-Tertiary alluvium or colluvium (QTac). In contrast, borehole UZ-14 (fig. 1) contains the contact between the Yucca Mountain Tuff and underlying strata of pre-Yucca Mountain Tuff bedded tuffs (Tpbt3) and exhibits a downward transition from devitrified and moderately welded to vitric (partially altered) and nonwelded.

Vitric to variably altered Yucca Mountain Tuff is non- to partially welded in older boreholes a\#4, a\#6, and a\#7 and nonwelded in boreholes a\#5 and $\mathrm{G}-4$ (fig. 1). The upper and lower formation contacts were recovered in boreholes $a \# 4$, $a \# 6$, and a\#7. The formation is partially recovered from borehole $\mathrm{G}-2$ (fig. 1), where it varies downward from moderately welded and devitrified to nonwelded and vitric or altered. This core preserves the lower formation contact with strata of the pre-Yucca Mountain Tuff bedded tuffs.

The Yucca Mountain Tuff is exposed in cliffs on the south side of Yucca Wash and the east side of Solitario Canyon. It varies from welded and devitrified in northern locations to nonwelded and vitric in southern locations with an apparently abrupt transition. The thickness of the Yucca Mountain Tuff was measured in eight stratigraphic sections (fig. 1; appendix 2).

\section{Generalized Unit and Contact Descriptions}

The Yucca Mountain Tuff generally contains less than 1 percent of phenocrysts (by visual estimate), primarily of subhedral feldspar with subordinate euhedral biotite. Lithic clasts of pale-red, medium to light-gray, and pale-brown to grayish-orange-pink devitrified volcanic rock typically compose 1 percent. Pumice clasts form less than 5 percent of the formation. Two types of pumice clasts occur: (1) Vesicular or frothy, vitric clasts with spherical to elongate vesicles; and (2) silky, finely fibrous clasts, likely devitrified or argillically altered. The former may be grayish black to medium gray, dark, moderate, or light yellowish brown, very pale orange, or colorless, whereas the latter are grayish orange, moderate orange-pink to pink, grayish orangepink, or light to very light gray. Pumice clasts that contain coarse vapor-phase crystals are brownish gray to light brownish gray.

Thick (a few meters or more), vitric sections of the Yucca Mountain Tuff (boreholes NRG-7/7A, SD-9) typically vary downward from shades of grayish orange-pink to shades of very light gray to shades of pale red or pale yellowish brown to shades of light or very light gray. The tuff is less variable in thinner sections and commonly is a single, uniform color in vertical sections of a few meters or less.

The vitric matrix of the Yucca Mountain Tuff, where nonwelded, is a porous mixture of subspherical, bubble-textured glass shards and platy glass shards enclosed in a fine, granular ash that varies from white or light gray to shades of pink. Partially welded tuff is characterized by fused ash particles, reduced porosity, and smooth fracture across shard boundaries. More extreme compaction and welding is identified by deformed shards with ellipsoidal shapes, elongated pumice clasts, and matrix foliation created by the subparallel alignment of shards and the major axes of bubbles. The colors of glass shards exhibit an apparent vertical zonation in thick sequences of Yucca Mountain Tuff, but it should be noted that shard color depends partly on the thickness of the shard wall and partly on the viewing angle. Glass shards are colorless near the upper and lower contacts but darken to shades of yellowish brown and grayish black in the interior of the tuff. Shard color, however, is not a useful indicator of cooling history or of stratigraphic position. For example, dark shard colors occur in the zone of maximum bubble deformation in borehole SD-9, below the zone of maximum deformation in UZ-14, and throughout the thin, nondeformed deposit in UZ \#16.

Where the tuff changes downward from vitric to devitrified (boreholes UZ-N11, UZ-N33, UZ-N34), the rock changes from shades of grayish orange-pink to shades of grayish brown and pale yellowish brown. Where the tuff changes downward from devitrified to vitric (borehole UZ-14), the rock changes from shades of grayish orange-pink and light brown to shades of pale yellowish brown to light or very light gray. 
The devitrified matrix of the Yucca Mountain Tuff is partially to moderately welded. Shard textures, which can be observed macroscopically in regions near the vitric/devitrified boundary, apparently are destroyed by recrystallization and alteration by vapor transport in the tuff interior. Remnant shards that are variably deformed and aligned define foliation. Intrashard voids, which form angular vesicles that decrease in abundance and size toward the interior of the formation, commonly are lined by minute, vapordeposited silica minerals. Devitrified shards typically are light brown and opaque.

The basal 10 to $40 \mathrm{~mm}$ of the formation is a coarse, clast-supported ground layer. The ground layer contains frothy to coarsely vesicular, vitric pumice clasts (20 to 30 percent) that typically have diameters of 10 to $20 \mathrm{~mm}$, lithic clasts of angular, devitrified volcanic rock and minor colorless, globule-textured glass ( 20 to 40 percent) that typically are smaller than $10 \mathrm{~mm}$, blocky, cuspate glass shards, and crystals of feldspar (less than 5 percent). The layer locally pinches and swells across exposures (for example, at measured section PTn\#8, fig. 1) and may be overlain by a thin (less than $20 \mathrm{~mm}$ ), laminated ash layer (for example, at measured section PTn\#4, fig. 1). The ground layer and laminated ash interval may be 40 to $50 \mathrm{~cm}$ thick in borehole G-2.

The upper contact of the Yucca Mountain Tuff commonly is disturbed by post-depositional processes. Irregular structures filled with material from the overlying deposits that locally occur in the upper meter of the formation are interpreted as burrows (fig. 13). Possible weathering effects that include reddish discoloration (iron staining?) and cloudy or frosty glass shards are observed in the upper several centimeters of the formation in several boreholes.

In exposures along Solitario Canyon, the upper few centimeters to meter of the Yucca Mountain Tuff may be slightly darker and more brown than typical, undisturbed Yucca Mountain Tuff. In some outcrops where the formation has a thickness of less than $2 \mathrm{~m}$, the unit is composed entirely of brownish tuff. Although this deposit appears composed of primary pyroclastic-flow material (delicate, bubble-textured glass shards are abundant in the matrix), it contains distinctive clasts of colorless, poorly vesicular glass that are not found elsewhere in the formation. The exposure at measured section PTn\#11, which captures the stratigraphic relation between the brownish unit and primary Yucca Mountain Tuff, illustrates the sec- ondary character of the brownish tuff (figs. 10 and 13). At this locale, angular blocks of primary tuff are eroded from the top of deposit and incorporated in the brownish tuff, which truncates underlying units of the pre-Yucca Mountain Tuff bedded tuffs. Blocks of Yucca Mountain Tuff also occur at the contact between the brownish tuff and overlying pre-Tiva Canyon Tuff bedded tuffs (Tpbt4) and within the lower few centimeters of Tpbt4 (see previous section). The brown tuff appears to include a mix of lithologies including Tpbt4, Tpbt3, and Tpy. Relations within the exposure suggest that the brown tuff may have been associated with a turbulent, high-velocity process, perhaps a volcanic blast or surge.

The contact between the Yucca Mountain Tuff and the underlying tephra of the pre-Yucca Mountain Tuff bedded tuff (Tpbt3) generally is sharp and undisturbed. This contact, which varies from planar to slightly undulatory, does not show evidence of erosion by the pyroclastic flows.

\section{Formation Distribution, Thickness, and Correlation}

The Yucca Mountain Tuff erupted from a source within the Claim Canyon caldera (Byers and others, 1976). An isochore map of the combined thicknesses of Tpy and Tpbt4 developed from borehole data in the Yucca Mountain region by Buesch, Nelson, and others (in press) depicts a sharp southward decrease in the aggregate unit thicknesses. Their isochore map additionally shows a thickness maximum along a possible south-trending paleovalley with an axis near the eastern boundary of the potential repository site.

Figure 14 shows the thickness of Yucca Mountain Tuff determined from boreholes and measured sections in this study. The hachured line marks the inferred location of an abrupt change in the formation thickness that crosscuts the potential repository site. Reconnaissance observation along Solitario Canyon cliff failed to reveal an unusual cause for the thickness change (such as paleotopographic or fault control), and it is possible that the deposit thins abruptly in distal reaches. 


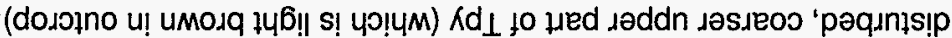

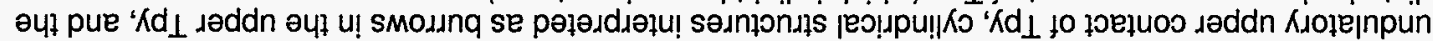

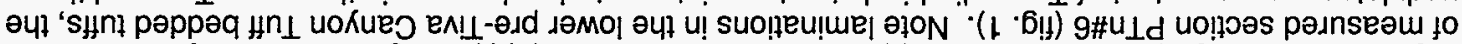

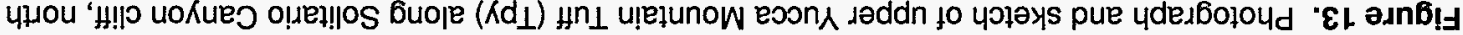
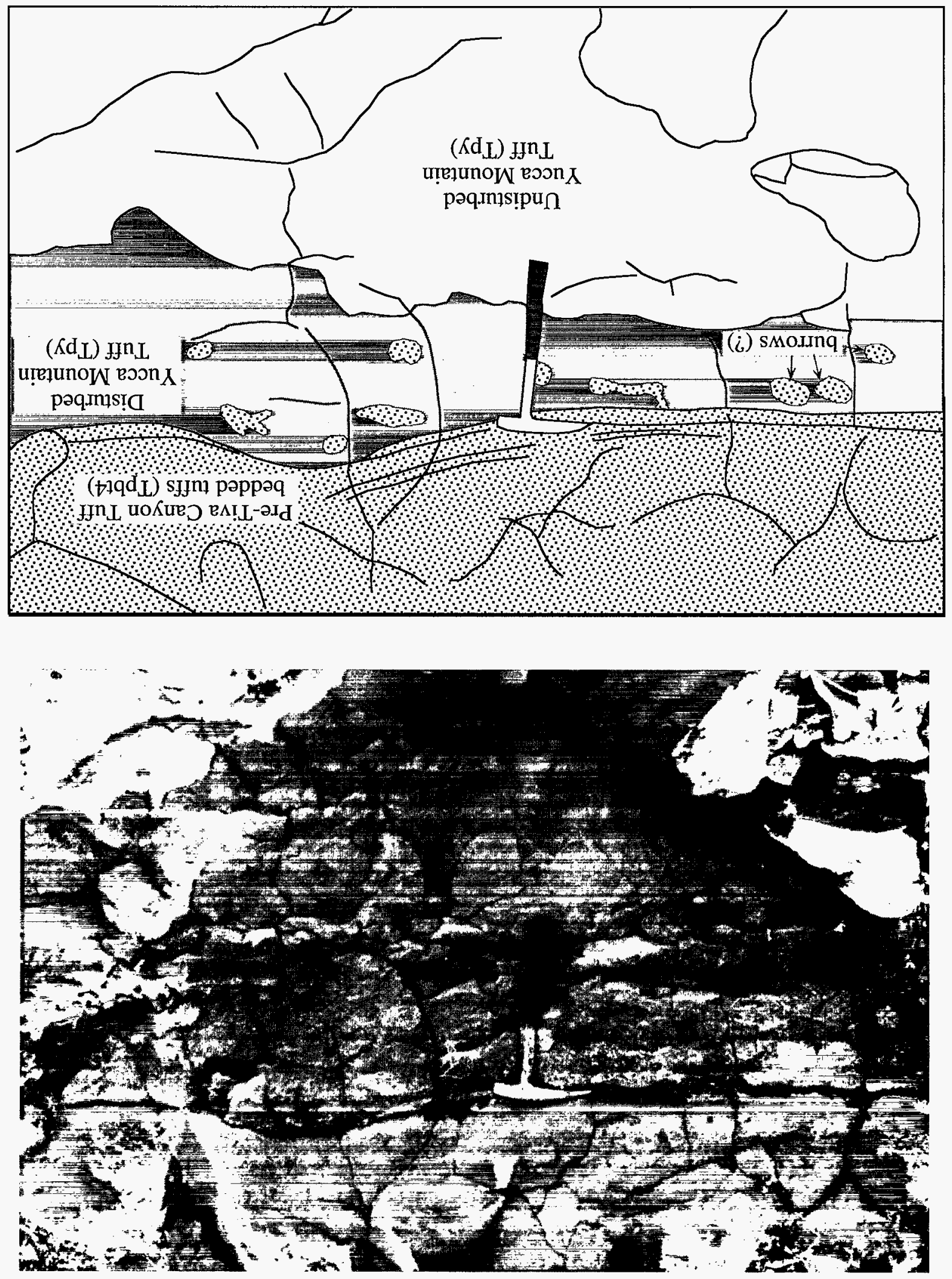


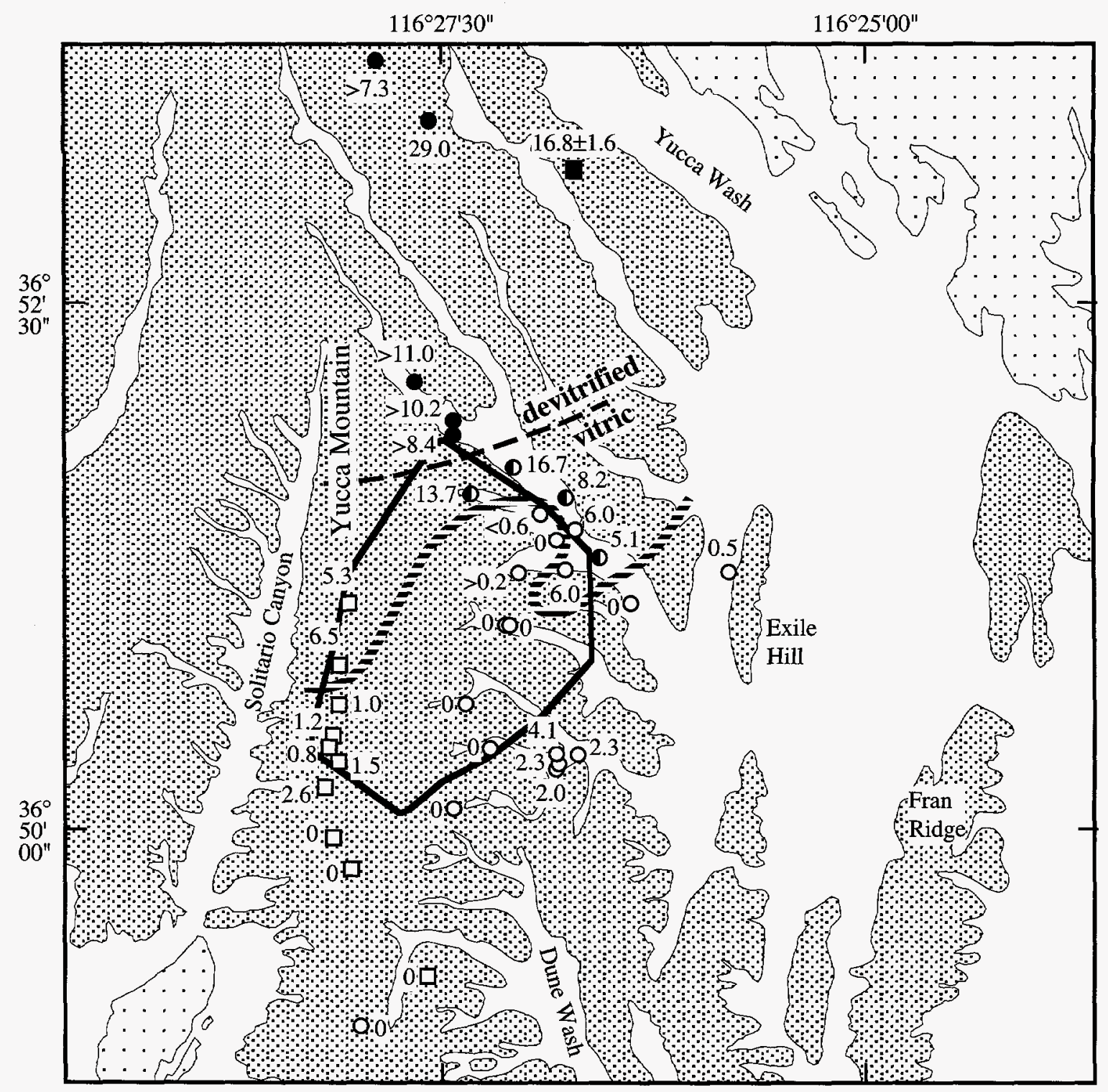

\section{EXPLANATION}

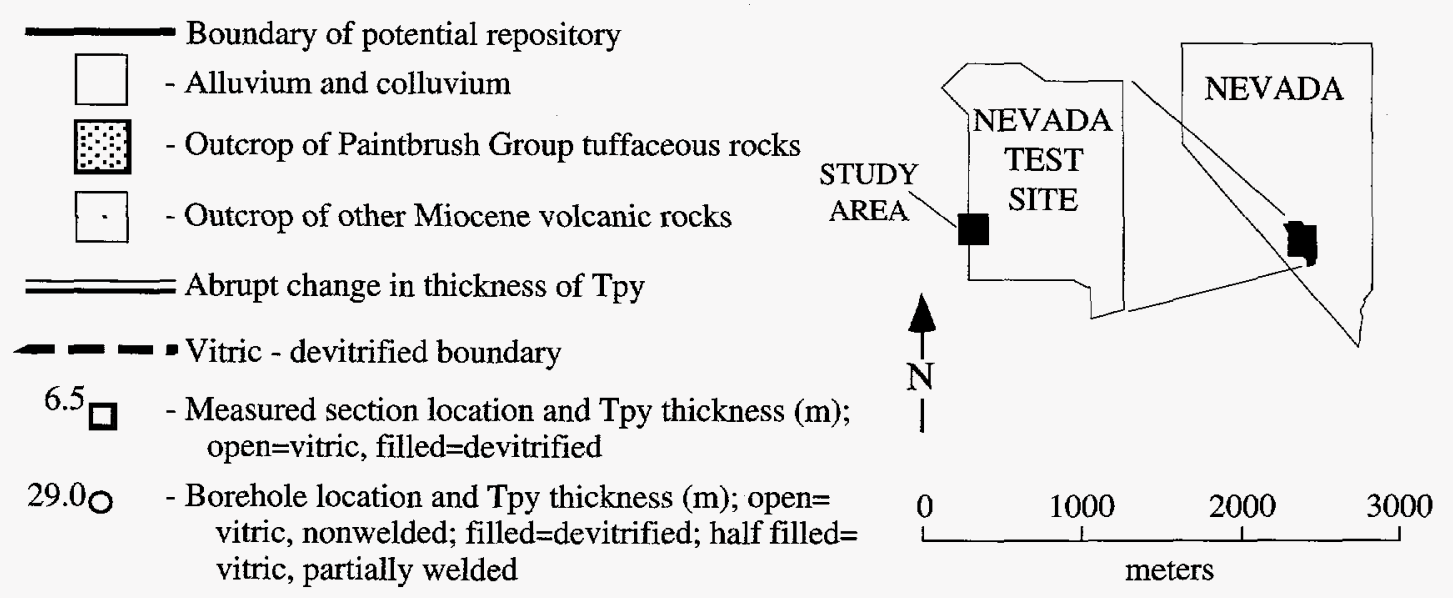

Figure 14. Isochore map showing apparent thickness of the Yucca Mountain Tuff in cored boreholes and measured sections. Borehole thicknesses are uncorrected for deviation from vertical; borehole a\#7 (see fig. 1) is corrected for inclination of $26^{\circ}$. 
The Yucca Mountain Tuff lacks depositional features or flow units that can be correlated throughout the site area. Moreover, lateral variations in the content of phenocrysts, pumice, and lithic clasts are not observed. Gradations in the degree of welding and types of secondary crystallization are apparent but difficult to quantify or illustrate because there are too few cored boreholes that penetrate complete stratigraphic sequences of welded tuff, particularly where the formation is devitrified. The problem is compounded by the absence of exposures in the transitional region. Figure 14 shows that a poorly defined region of vitric, partially welded tuff separates a northern region of devitrified, moderately welded tuff from a southern region of vitric, nonwelded tuff. The geometry and nature of the abrupt transition from devitrified to vitric tuff (fig. 14) presently are unknown.

\section{Features of Welding, Secondary Crystallization, and Alteration}

As first described by Lipman and Christiansen (1964), the Yucca Mountain Tuff is a simple cooling unit that is partially to moderately welded throughout the northern part of the potential repository-site area. In this northern part, the interior of the deposit is devitrified and variably altered by vapor transport. Lipman and Christiansen (1964) identified a central lithophysal zone in thick sections of the tuff. Table 4 summarizes the vertical variations in welding and secondary crystallization observed in cored boreholes at Yucca Mountain. Note that the downward variations in the degree of welding are gradational changes; the contacts listed in table 4 are located where these features become the primary characteristic of the rock.

The Yucca Mountain Tuff grades downward from nonwelded to partially or moderately welded in boreholes NRG-7/7A, SD-9, UZ-N11, and UZ-N33. Coarsening of the ash matrix downward, presumably caused by sintering of fine particles, is accompanied by a change in the appearance of freshly broken surfaces. Where the tuff is nonwelded, glass shards protrude above the ash matrix, revealing glassy shard "walls" where the matrix ash falls away. Broken surfaces remain irregular, but are more subdued, as ash sinters to the outer surface of the shards with the onset of welding. Welding also causes shards with subspherical bubble walls to deform into ellipsoidal shapes. With more intense welding, the rock fractures smoothly across the vitroclastic texture as the ash matrix fuses into a homogeneous mass. At this stage, pumice clasts are moderately elongate, the matrix is foliated, and vesicles are less abundant and are lenticular or irregularly elongate. Increased welding further reduces the size and amount of intrashard vesicles to the point that they cannot be resolved macroscopically. These welding changes can be observed in generally reversed order in the lower part of the tuff.

There are no boreholes that were cored through the entire interval of Yucca Mountain Tuff where it is welded and devitrified. Three boreholes (UZ-N11, $\mathrm{UZ}-\mathrm{N} 33$, and $\mathrm{UZ}-\mathrm{N} 34$ ) capture the downward transition from non- or partially welded vitric tuff to partially or moderately welded, devitrified tuff. The change from vitric to devitrified shards is abrupt, occurring over an interval of $15 \mathrm{~cm}$ or less (table 4). Shard textures commonly are preserved immediately below the transition, but locally are destroyed by recrystallization and alteration by vapor transport at deeper levels. A silicified zone, within which vesicles are filled with silica or coated with minute vapor-phase crystals, occurs below the vitric-devitrified boundary. This zone is typified by a dense, silica-replaced matrix, smooth, sharp (quasi-conchoidal) fracture, and grayish-brown to pale yellowish-brown colors. Underlying the silicified zone is a region of vapor-phase mineralization within which crystals of tridymite or cristobalite and hematite line or fill vesicles and replace pumice clasts. Vapor-phasereplaced pumice clasts, despite variable flattening that defines a foliation, have secondary porosity created by the open arrangement of crystals. The amount of vapor-phase crystallization decreases downward as vesicles decrease in abundance and pumice clasts become more elongated.

Boreholes UZ-14 and G-2 contain the transition from moderately to densely welded, devitrified tuff to non- to partially welded, vitric tuff (table 4). Shard textures are preserved throughout the cored interval in both boreholes. Vapor-phase mineralization of the devitrified matrix and pumice clasts is prominent at the top of the cored interval in both boreholes but diminishes downward (table 4). The devitrified region, which contains shards that are deformed and aligned, fractures in a sharp, crudely conchoidal manner. The degree of welding begins to decrease in the lower part of the devitrified region, as marked by an increase in the amount and size of intrashard vesicles and a change to more equant vesicle shapes. The transition from devitrified to vitric shards is abrupt, occurring over an interval of less than $30 \mathrm{~cm}$. A thin ( 1 to $2 \mathrm{~m}$ ) interval 
Table 4. Depths to welding and crystallization features in the Yucca Mountain Tuff

[All depths are in meters, measured along the core axis; --, not applicable; $v$, contact taken from video of core prior to sample removal; <, less than; N.P., interval or unit is not present; vitric-devitrified boundary based on shard character]

\begin{tabular}{|c|c|c|c|c|c|c|c|c|c|}
\hline & \multicolumn{9}{|c|}{ Borehole number } \\
\hline & NRG-7/7A & SD-9 & UZ-N11 & UZ-N33 & UZ-N34 & $U Z-14$ & a\#4 & a\#5 & $G-2^{1}$ \\
\hline Tpy/QTac contact & -- & -- & -- & -- & 15.4 & ${ }^{2} 12.8^{v}$ & -- & -- & 288.3 \\
\hline Tpy/Tpbt4 contact & 32.4 & 29.2 & 18.5 & 14.4 & -- & -- & $46.3 \pm 0.1$ & $45.6 \pm 0.1$ & - \\
\hline $\begin{array}{l}\text { Onset of bubble-wall } \\
\text { shard deformation }\end{array}$ & 35.2 & 32.6 & $19.9 \pm 0.2$ & 16.8 & $<15.4$ & -- & 48.8 & 46.6 & -- \\
\hline $\begin{array}{l}\text { Vitric to devitrified } \\
\text { transition }\end{array}$ & N.P. & N.P. & $21.5-21.6$ & $18.3-18.4$ & $16.5-16.6$ & -- & N.P. & N.P. & - \\
\hline $\begin{array}{l}\text { Zone of matrix } \\
\text { silicification }\end{array}$ & N.P. & N.P. & $21.9-22.2$ & $18.7-19.4$ & $17.4-18.0$ & -- & N.P. & N.P. & - \\
\hline $\begin{array}{l}\text { Prominent vapor-phase } \\
\text { mineralization } \\
\text { within pumice and } \\
\text { matrix }\end{array}$ & N.P. & N.P. & ${ }^{3} 22.2-25.7$ & ${ }^{3} 20.6-22.9$ & ${ }^{3} 18.5-25.6$ & -- & N.P. & N.P. & -. \\
\hline $\begin{array}{l}\text { Region of maximum } \\
\text { bubble-wall shard } \\
\text { deformation }\end{array}$ & $37.8-39.0$ & $35.1-36.6$ & & & & -- & -- & -- & $<18.3-99.1$ \\
\hline $\begin{array}{l}\text { Vapor-phase alteration } \\
\text { diminishes }\end{array}$ & N.P. & N.P. & & & & 15.5 & N.P. & N.P. & 94.5 \\
\hline $\begin{array}{l}\text { Devitrified to vitric } \\
\text { transition }\end{array}$ & N.P. & N.P. & & & & $19.6^{v}$ & N.P. & N.P. & 101.6 \\
\hline $\begin{array}{l}\text { Zone of argillic } \\
\text { alteration }\end{array}$ & N.P. & N.P. & & & & $19.8-21.6$ & N.P. & N.P. & $101.5-102.4$ \\
\hline $\begin{array}{l}\text { End of bubble-wall } \\
\text { shard deformation }\end{array}$ & 43.3 & 41.1 & & & & 22.6 & 52.0 & 48.8 & 101.8 \\
\hline Tpy/Tpbt 3 contact & $48.2 \pm 0.6$ & 42.9 & & & & $23.8^{\mathrm{V}}$ & $51.6 \pm 0.1$ & $51.6 \pm 0.05$ & 104.1 \\
\hline
\end{tabular}

of argillic alteration occurs immediately below the devitrified-vitric boundary; the intensity of argillic alteration varies from complete (shards and matrix are destroyed) to partial (shards remain glassy). The tuff appears vitric and unaltered below the interval of clay alteration.

\section{Pre-Yucca Mountain Tuff Bedded Tuffs (Tpbt3)}

The pre-Yucca Mountain bedded tuffs (Tpbt3) are heterolithologic, nonwelded, tuffaceous deposits that occur throughout the study area. This study divides Tpbt 3 into seven informal units designated $\mathrm{A}$ through $\mathrm{G}$, from base to top. These units include pyroclastic-fall deposits, pyroclasticflow deposits, and slightly reworked or weathered tuffaceous deposits. Units A through D, F, and G are laterally continuous in the study area, whereas unit $\mathrm{E}$ is thick in the northern part of Yucca Mountain, thins abruptly southward, and pinches out in the northern part of the potential repository area. Pre-Yucca Mountain Tuff bedded tuffs conformably overlie the Pah Canyon Tuff (Tpp) or the pre-Pah Canyon Tuff bedded tuffs, where Tpp is absent. In most locations, Tpbt 3 is conformably overlain by the Yucca Mountain Tuff (Tpy) or, where Tpy is absent, the pre-Tiva Canyon Tuff bedded tuffs (Tpbt4). At measured section PTn\#11 (fig. 1; appendix 2), units G, F, D, and $C$ are truncated by the brown tuff at the top of the Yucca Mountain Tuff and by unit B of the pre-Tiva Canyon Tuff bedded tuffs (fig. 10).

Abbreviated unit and contact descriptions for Tpbt 3 are given below. Unit and contact descriptions were developed from observations of core recovered from boreholes NRG-7/7A, NRG-6, UZ-14, SD-9, SD-12, UZ-N37, and UZ \#16 (fig. 1). Additional

30 Stratigraphic Relations and Hydrologic Properties of the Paintbrush Tutf Nonwelded (PTn) Hydrologic Unit, Yucca Mountain, Nevada 
observations of core from several older boreholes and of exposures at nine measured sections along the east side of Solitario Canyon, near Yucca Wash, and in Abandoned Wash (fig. 1; appendix 2) were used to clarify lateral variability and stratigraphic relations.

\section{Generalized Unit and Contact Descriptions}

\section{Unit G}

Unit $\mathrm{G}$ is a light-brown, poorly sorted, clastsupported fallout (?) that is weathered or slightly reworked. This unit typically is 0.5 to $1.0 \mathrm{~m}$ thick. Pumice content ranges from 40 to 50 percent to. 70 to 85 percent. Pumice clasts typically are white, vitric, and from 1 to $4 \mathrm{~mm}$, with some clasts to $30 \mathrm{~mm}$. Lithic-clast content ranges from 10 to 30 percent to 40 to 50 percent. Lithic clasts, typically 1 to $5 \mathrm{~mm}$ but up to $25 \mathrm{~mm}$, include dominant colorless glass (some perlitic), subordinate pale-red devitrified volcanic rocks, and rare obsidian. The unit is crystal poor ( 1 to 3 percent?) and contains dominantly feldspar crystals; however, it is difficult to distinguish crystals from small lithic clasts of colorless glass. Locally, the unit contains minor amounts of light-brown matrix. Grains are angular to subrounded and have a brownish coating that gives the rock an overall light-brown color. The upper contact is sharp and depositional; the lower contact is typically gradational over approximately $5 \mathrm{~cm}$.

In outcrops at measured sections PTn\#2, PTn\#8, and PTn\#10 (fig. 1; appendix 2), unit G contains cylindrical structures as large as $8 \mathrm{~cm}$ in diameter that are interpreted to be animal burrows (fig. 15). The burrows are filled with material from the overlying unit; for example, at measured section PTn\#8, the burrows are filled with material from the overlying Tpy, while at measured section PTn\#10, the burrows are filled with material from the overlying Tpbt4 unit B (fig. 15).

\section{Unit F}

Unit $F$ is composed of several thin beds ( 1 to $10 \mathrm{~cm}$ thick) of light-gray to tan fallout. The unit typically is 50 to $75 \mathrm{~cm}$ thick. Grain sizes vary from 1 to $10 \mathrm{~mm}$ but are relatively uniform within beds. Pumice content ranges from 40 to 60 percent to 70 to 80 percent. Pumice clasts are vitric and white, grayish pink, and grayish orange. Lithic-clast content ranges from 20 to 30 percent to 40 to 60 percent, with clast types that include dominant colorless to very light-gray glass (some perlitic), subordinate light-gray, pale-red, moderate red, and light-brown devitrified volcanic rocks, and very rare obsidian. The unit, which contains phenocrysts of feldspar, oxidized biotite, and (rare) hornblende, appears crystal poor ( 1 to 5 percent?); however, crystal content is equivocal because it is difficult to distinguish feldspar crystals from small clasts of colorless glass. Where unit $E$ is absent, unit $F$ can be distinguished from unit $D$ by its abundant colorless to light-gray glassy lithic clasts and its generally finer grain size. The lower contact of the unit is sharp, locally undulatory, and depositional.

\section{Unit $E$}

Unit $\mathrm{E}$ occurs as a sequence of nonwelded pyroclastic-flow deposits in the northern part of Yucca Mountain (for example, boreholes G-2 and UZ-14 and measured section PTn\#1; fig. 1). Within the potential repository site, unit $\mathrm{E}$ is a thin, ash-rich fallout that is present in only a few boreholes (for example, NRG-7/7A and NRG-6). The pyroclasticflow deposits have a maximum observed thickness of $44 \mathrm{~m}$ in borehole $\mathrm{G}-2$, whereas the fallouts generally are less than $0.2 \mathrm{~m}$ thick. As seen in measured section PTn\#1 (fig. 1, appendix 2), unit E is composed of several pyroclastic-flow deposits that vary slightly in character. The following is a generalized description of these deposits.

The pyroclastic-flow deposits have a vitric, ashy matrix that is white to grayish orange-pink. Pumice clasts (ranging from 5 to 7 percent to 20 to 35 percent) are dominantly white and vitric. Pumice clasts commonly have diameters of 3 to $50 \mathrm{~mm}$; however, large, blocky pumice clasts (up to $630 \times 490 \mathrm{~mm}$ ) are present in the tops of some flow units at measured section PTn\#1. Lithic clasts (ranging from 2 to 25 percent) are mostly smaller than $15 \mathrm{~mm}$, rarely to $40 \mathrm{~mm}$, and include dominant very light-gray to colorless perlitic glass, subordinate pale yellowish-brown, pale-red, moderate brown, and medium light-gray devitrified volcanic rocks, and rare obsidian. Crystals ( 3 to 5 percent) include feldspar, magnetite (?), and very rare hornblende. A minimum of four flow units are identified at measured section PTn\#4. 


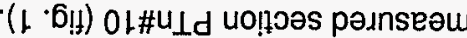

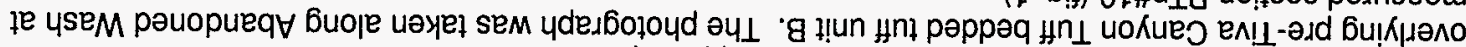

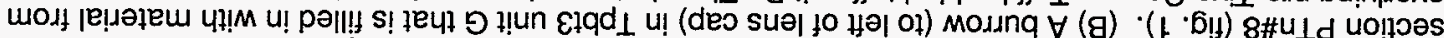

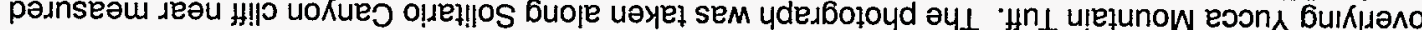

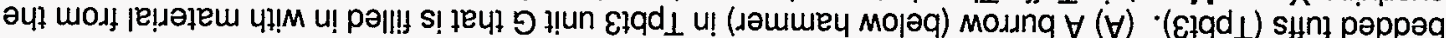

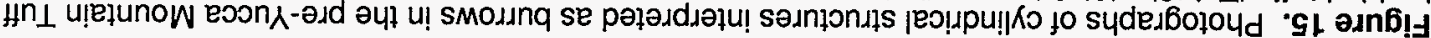
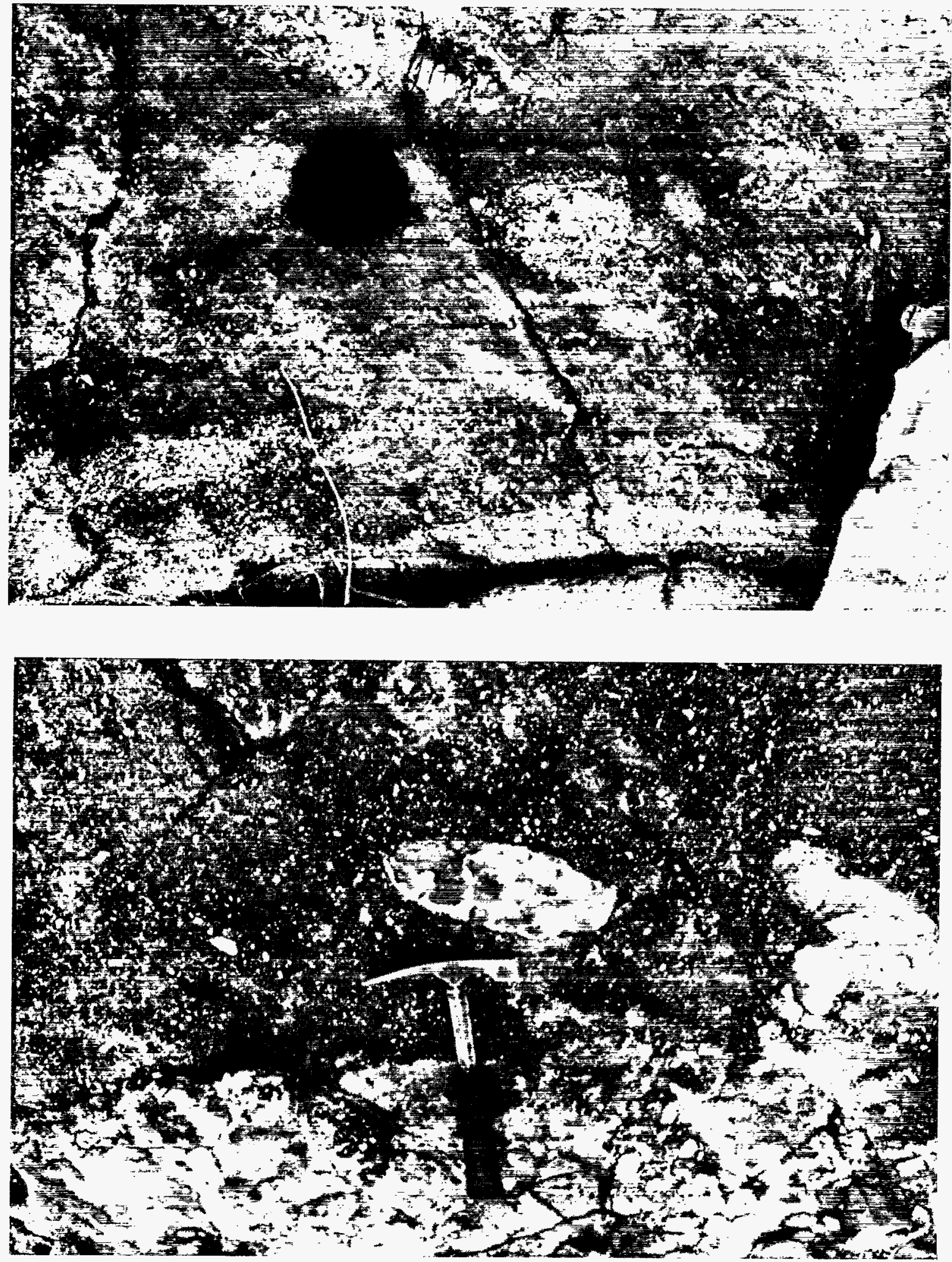
Ash-rich fallouts typically have a moderate orange-pink matrix ( 30 to 40 percent). Pumice clasts (10 to 30 percent) are vitric, moderate orange-pink to grayish orange-pink, and 2 to $3 \mathrm{~mm}$ in diameter. Lithic clasts ( 25 to 60 percent) include dominant colorless to very light-gray glass and subordinate obsidian and pale-red devitrified volcanic rocks, typically from 1 to $3 \mathrm{~mm}$ in diameter. Ash coatings on grains makes identification of crystals difficult; however, the unit appears to contain approximately 5 percent crystals of feldspar. The lower contact of the unit is sharp and depositional.

\section{Unit D}

Unit D is a light-gray, coarse, moderately sorted fall deposit that is commonly from 30 to $70 \mathrm{~cm}$ thick. The unit is thinly bedded, with 1- to 3-cm-thick beds. Grain sizes vary from 1 to $15 \mathrm{~mm}$ for the unit but are less variable within individual beds. Vitric pumice clasts ( 60 to 90 percent) are white, pale yellowish orange, and light brown. Lithic clasts (ranging from 5 to 7 percent to 30 to 40 percent) include dominant devitrified volcanic rocks that are moderate light gray, pale brown, pale red, and moderate reddish brown, with subordinate, colorless perlitic glass, and rare obsidian. Lithic clasts appear iron stained or "rusted" in some horizons. Crystals ( 1 to 5 percent) include feldspar and rare, oxidized biotite. The lower unit contact is sharp and depositional.

\section{Unit C}

Unit $C$ is a meter-thick, tan, moderately sorted, pumiceous fallout with 2 to 10 percent light-brown matrix. The presence of matrix suggests the deposit represents a weathered or slightly reworked deposit. Pumice clasts ( 70 to 90 percent) are subrounded, mostly smaller than 1 to $3 \mathrm{~mm}$ (rarely up to $20 \mathrm{~mm}$ ), white with a light-brown coating, and vitric. Lithic clasts ( 2 to 15 percent) are mostly smaller than $2 \mathrm{~mm}$ (rarely up to $6 \mathrm{~mm}$ ) and include pale-red, moderate brown, and moderate light-gray devitrified volcanic rocks, colorless glass (some perlitic), and rare obsidian. Crystals ( 1 to 3 percent) include feldspar, hornblende, and oxidized biotite. Locally, a discontinuous, coarse, pumiceous interval occurs approximately $5 \mathrm{~cm}$ below the top of the unit. The lower unit contact is typically irregular and gradational over 3 to $10 \mathrm{~cm}$.

\section{Unit B}

Unit B is an orange-brown to reddish-brown, poorly sorted, clast-supported to matrix-supported, weathered or reworked fall deposit. This unit generally is from 1 to $3 \mathrm{~m}$ thick. The matrix content of the unit increases upward from 15 to 25 percent near the base to 40 to 60 percent near the top. The matrix, which coats all grains, typically is moderate reddish orange to grayish orange-pink, and rarely light brown. Pumice content decreases upward from 30 to 60 percent near the base to 15 to 20 percent near the top of the unit. Most pumice clasts are smaller than $10 \mathrm{~mm}$ (rarely up to $25 \mathrm{~mm}$ ), white to grayish orange pink, vitric to slightly altered, and crystal-bearing. The decrease in pumiceclast content and increase in matrix content upward gives the unit the appearance of being normally graded; however, it may indicate the top of the unit is weathered or reworked. Lithic clasts (ranging from 3 to 5 percent to 10 to 25 percent) are mostly smaller than $2 \mathrm{~mm}$ and include dominant pale to moderate red and moderate light-gray devitrified volcanic rocks, and subordinate, colorless, perlitic glass. Crystals ( 2 to 7 percent) include feldspar, biotite, and oxidized biotite. The lower unit contact is generally gradational over 5 to $10 \mathrm{~cm}$; however, locally it is sharp.

In outcrops at measured section PTn\#8 (fig. 1), cylindrical burrow structures are present near the upper contact of unit $\mathrm{B}$ and at the unit B-unit $\mathrm{C}$ contact. The burrows are filled with coarse pumiceous material that appears to be from unit $D$.

\section{Unit A}

Unit A is a gray, coarse-grained, pumice-fall deposit that generally is 0.75 to $1.2 \mathrm{~m}$ thick. Pumice clasts ( 70 to 90 percent) are very light gray to moderate orange-pink, contain crystals of feldspar and oxidized biotite, are vitric to slightly altered, and are commonly from 5 to $20 \mathrm{~mm}$ in diameter. Some pumice clasts have pale yellowish-orange rims. Lithic clasts (typically 2 to 7 percent, locally to 15 percent) include dominant pale-red, moderate light-gray, and grayish-red devitrified volcanic rocks, and rare colorless to very lightgray perlitic glass, obsidian, and light-red glass. Lithic clasts, which are typically smaller than pumice clasts, are mostly smaller than $5 \mathrm{~mm}$. Crystals ( 3 to 5 percent) include abundant oxidized biotite, feldspar, unaltered biotite, and very rare clinopyroxene. The lower unit contact is sharp and depositional. 


\section{Unit Distribution and Thickness}

Pre-Yucca Mountain Tuff bedded tuffs occur in boreholes and outcrops throughout the study area. Although the cumulative thickness of units other than unit $E$ is fairly uniform throughout the area (fig. 16), the thickness of unit $E$ changes markedly from north to south in the Yucca Mountain region (fig. 17). Units A through $\mathrm{D}$ and unit $\mathrm{F}$ are generally present in all boreholes and at all measured sections in the study area (appendixes 2 and 3 ). In contrast, the distribution of unit $G$ appears to be related to the presence of the overlying Yucca Mountain Tuff. In all boreholes and measured sections except GU-3, PTn\#2, and PTn\#10 (fig. 1, appendixes 2 and 3), unit $\mathrm{G}$ is absent wherever the Yucca Mountain Tuff absent. The significance of this correlation is unknown.

Unit $\mathrm{E}$ thins markedly southward and pinches out in the central part of the potential repository site (fig. 17). Its maximum thickness of $44.0 \mathrm{~m}$ occurs in the northern part of the study area at borehole G-2 (figs. 1 and 17), and it has been recognized as far south as borehole UZ \#16 where it is less than $0.1 \mathrm{~m}$ thick. Although dramatic, the steep thickness gradient illustrated in figure 17 (the pyroclastic-flow deposits thin from $44 \mathrm{~m}$ to $2 \mathrm{~m}$ in less than $2.5 \mathrm{~km}$ laterally) is consistent with many small-volume pyroclasticflow deposits that tend to be channelized and deposited by flows with comparatively high yield strength (Cas and Wright, 1987). The large pumice blocks observed at the tops of flow units at measured section PTn\#1 (appendix 2) and the general character of the pyroclastic-flow deposits are similar to many small-volume block-and-ash-flow deposits (Cas and Wright, 1987). In this sense, the ash-rich fallout may represent a co-ignimbrite ash (Cas and Wright, 1987).

Byers and others (1976) inferred a source for pyroclastic material of Tpbt 3 within the Claim Canyon caldera. However, Broxton and others (1993), in a subsequent study of the petrography and chemistry of samples collected from the location of measured section PTn\#1, concluded that deposits above unit D are correlative with the rhyolite of Black Glass Canyon, and that deposits below are correlative with the rhyolite of Delirium Canyon.

\section{Features of Reworking}

Several of the units in Tpbt 3 possess features consistent with weathering or slight reworking. These features include tan or orange-brown ("rusty") coloration, matrix content that appears to increase upward in a unit, poor sorting, and animal burrows. Units B, $\mathrm{C}$, and $\mathrm{G}$ are most likely to have been weathered or reworked. Units $\mathrm{G}$ and $\mathrm{C}$ are tan, contain minor amounts of matrix near the top of the unit, and commonly contain burrows. Unit B is rust colored, in hand sample appears to contain abundant matrix in the top of the unit, and locally contains burrows.

\section{Pah Canyon Tuff (Tpp)}

Six boreholes drilled since 1991 contain comparatively complete stratigraphic sections of Pah Canyon Tuff (Tpp) and an additional four post-1991 boreholes contain partial sequences (less than 70-percent recovery). The formation is non- to partially welded in these 10 boreholes and vitric to slightly altered in all boreholes except NRG \#4, where it grades downward from vitric to zeolitically altered, and in borehole NRG \#2B, where it is altered to clays or zeolites throughout.

Pah Canyon Tuff occurs in seven older cored boreholes. Core samples of non- to partially welded Pah Canyon Tuff recovered from boreholes a\#4, a\#5, a\#6, a\#7, and G-4 are partially to mostly vitric. Core recovered from borehole a\#1 grades downward from argillically altered to vitric. In borehole $\mathrm{G}-2$, the formation is a simple cooling unit composed of upper and lower nonwelded, vitric zones that enclose a moderately welded, devitrified interior. The formation is variably altered in G-2 and includes intervals of argillic alteration, silicification, minor zeolitization, and heulandite mineralization (Caporuscio and others, 1982).

The Pah Canyon Tuff was examined in exposures on cliffs bordering the south side of Yucca Wash and the east side of Solitario Canyon. The formation is welded and devitrified in exposures near Yucca Wash, but is nonwelded and vitric throughout most of the site area. The thickness of Pah Canyon Tuff was measured in seven stratigraphic sections (fig. 1; appendix 2). 


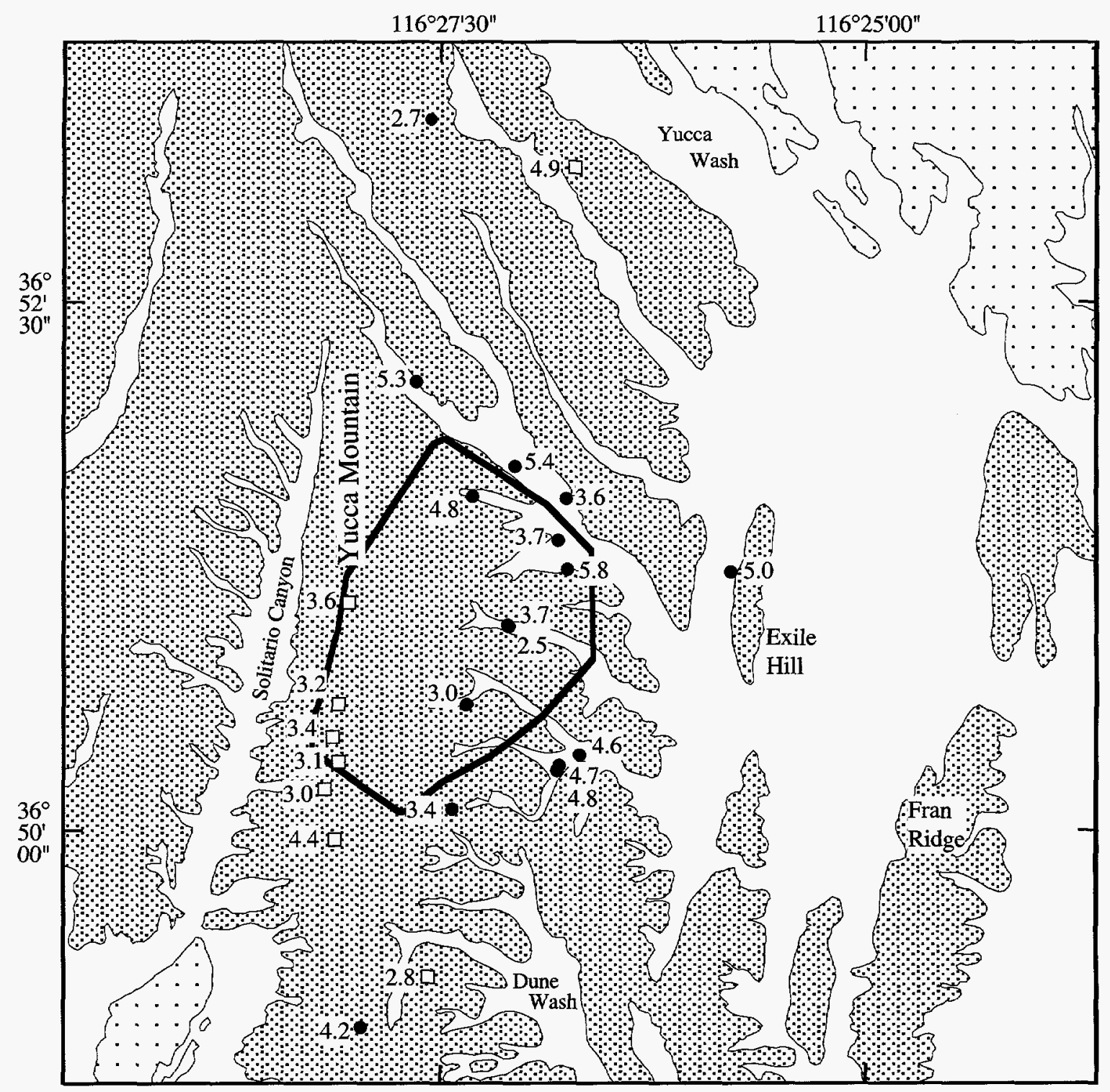

\section{EXPLANATION}

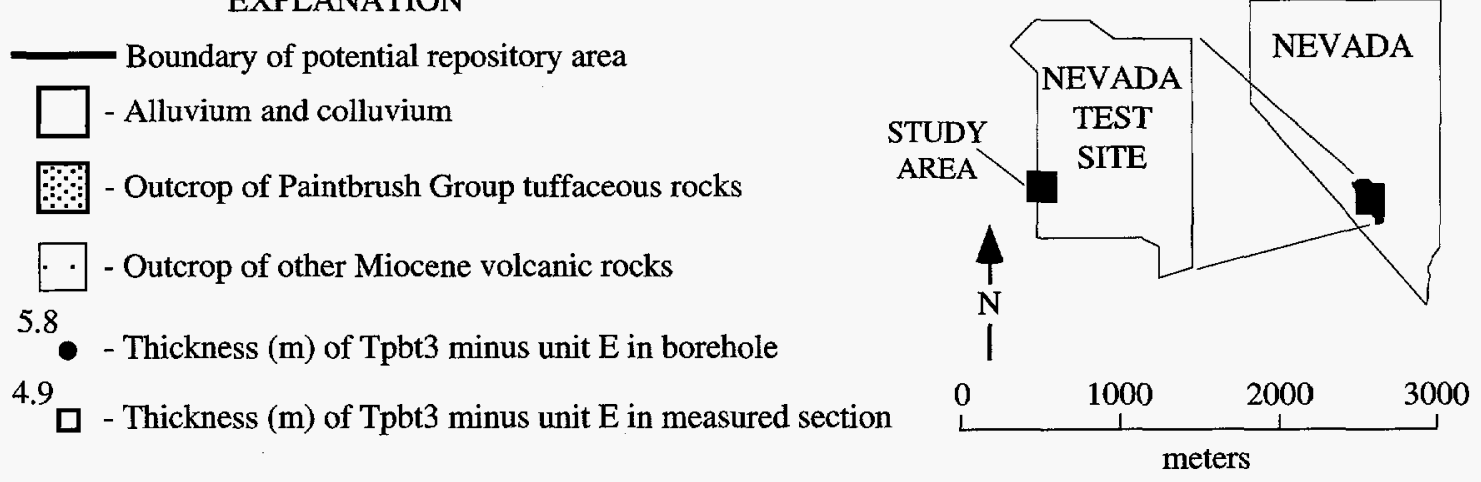

Figure 16. The combined apparent thickness of all pre-Yucca Mountain Tuff bedded tuff (Tpbt3) units except unit $\mathrm{E}$. Values for boreholes are drilled thicknesses uncorrected for deviation from vertical, and values for measured sections are vertical thicknesses. 


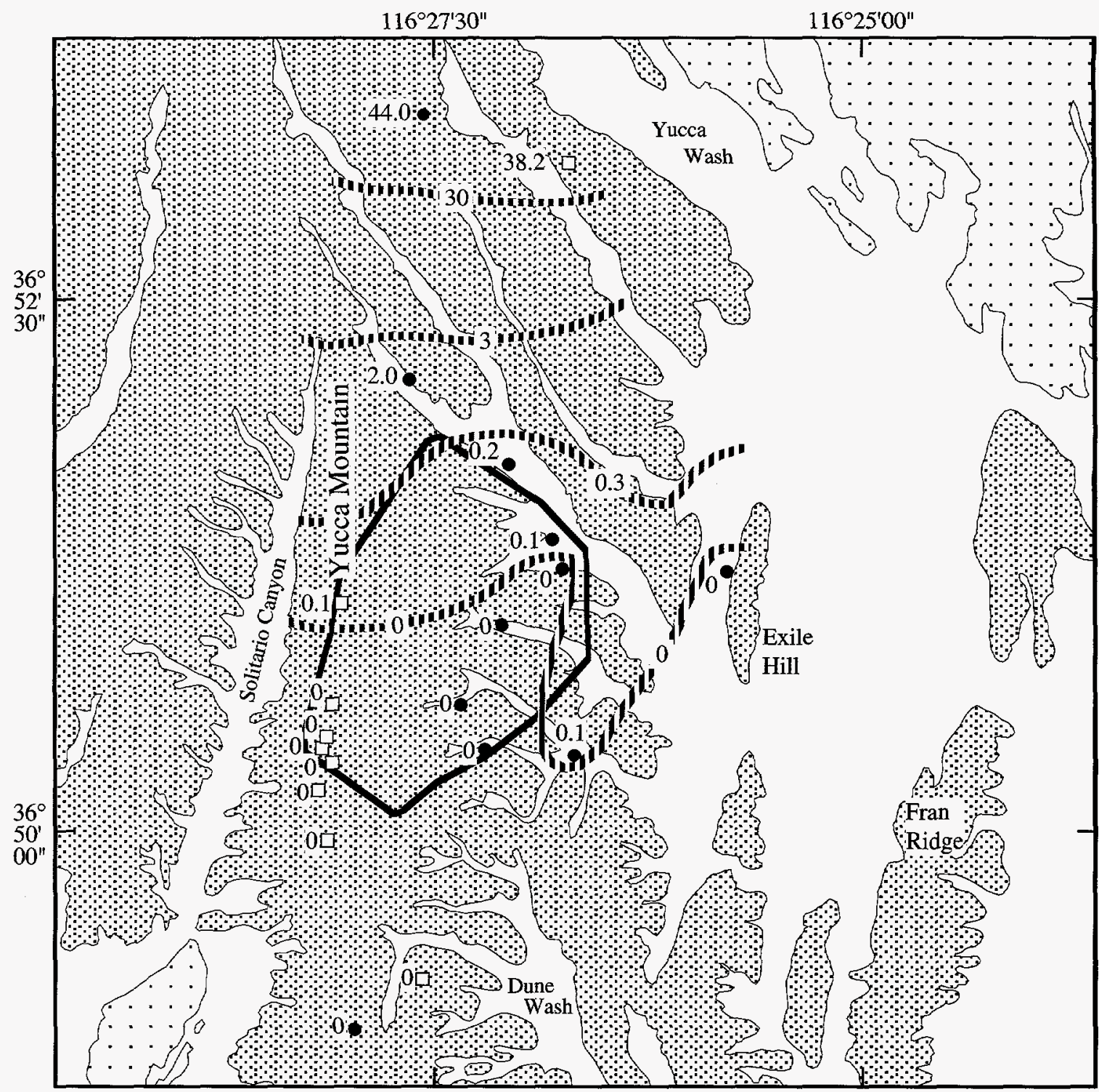

EXPLANATION

Boundary of potential repository area

- Alluvium and colluvium

- Outcrop of Paintbrush Group tuffaceous rocks

- - Outcrop of other Miocene volcanic rocks

III3।II Contour line of thickness (m) of Tpbt3 unit $\mathrm{E}$

- Thickness (m) of Tpbt3 unit $\mathrm{E}$ in borehole

38.2

- Thickness ( $m$ ) of Tpbt3 unit $E$ in measured section

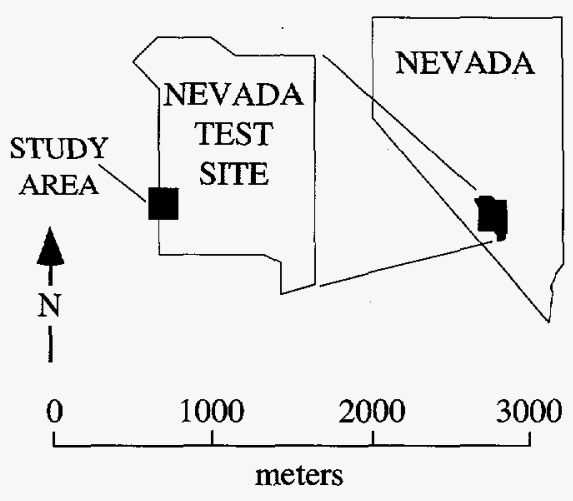

Figure 17. Apparent thickness of pre-Yucca Mountain Tuff bedded tuff (Tpbt3) unit $E$. Values for boreholes are drilled thicknesses uncorrected for deviation from vertical, and values for measured sections are vertical thicknesses. 


\section{Unit and Contact Descriptions}

The Pah Canyon Tuff (Tpp) is a pyroclastic-flow deposit composed of phenocrysts, pumice clasts, lithic clasts, glass shards, and ash. Phenocryst content varies irregularly within the formation. In general, the tuff contains from 5 to 10 percent phenocrysts (locally 10 to 15 percent in borehole G-2), primarily of feldspars with lesser biotite (locally partly oxidized) and minor to rare clinopyroxene and iron-titanium oxide. Lithic clasts, which also vary irregularly, compose from 1 to 2 percent to 5 to 7 percent of the deposit; lithic clasts are more abundant in borehole G-2 (locally 10 to 12 percent), which is at the northern tip of Yucca Mountain. Lithic clasts are primarily of devitrified volcanic rock in shades of grayish red to pale red, medium to light gray, and moderate to light brown, with subordinate clasts of grayish-black to medium dark-gray or moderate reddish-brown glassy volcanic rock. Typical clast diameters are larger in borehole G-2 (generally 1 to $10 \mathrm{~mm}$ ) than in other boreholes (generally 1 to $5 \mathrm{~mm}$ ).

The matrix of nonwelded, vitric Pah Canyon Tuff is composed of blocky pumiceous fragments and granular ash with variable, but minor, amounts of platy to curviplanar (locally cuspate) glass shards that are difficult to see in hand sample. Typically colorless, shards may occur in shades of yellowish brown or dark gray. Vitric Pah Canyon Tuff commonly varies downward from shades of grayish pink to orange-pink to very pale orange or white (appendix 1).

The devitrified matrix of the Pah Canyon Tuff is partially to moderately welded. As the formation changes downward from vitric to devitrified, the rock becomes moderate to light brown, then grades to shades of grayish orange-pink. Remnant shards are variably deformed and rarely preserved (macroscopically) where vapor-phase mineralization affected the interior of the deposit. Intrashard porosity diminishes downward but is not eliminated by the welding process.

Abundant, large pumice clasts are a distinctive feature of the Pah Canyon Tuff. Typically, vitric pumice clasts compose from 10 to 40 percent of the formation, are nondeformed, frothy to coarsely vesicular or silky with elongate tubular vesicles, and subangular to subrounded. They vary from less than
$10 \mathrm{~mm}$ to greater than $170 \mathrm{~mm}$ as measured along the core axis. Pumice is locally concentrated into swarms of large clasts.

The three types of pumice clasts observed in the Pah Canyon Tuff vary downward in a semi-regular fashion and can be used to correlate stratigraphic position in some boreholes. Flow-unit boundaries based on changes in pumice-clast type are discussed below and presented in table 5 .

Type I pumice clasts occur at the top and bottom of the Pah Canyon Tuff. They are vitric, nondeformed, frothy vesicular, with 3 to 5 percent crystals of feldspar, subordinate biotite, and minor pyroxene. Clasts are typically light to very light gray, but may grade to medium light gray or shades of very pale orange. Type I clasts vary from smaller than $10 \mathrm{~mm}$ to greater than $170 \mathrm{~mm}$ along the core length with equant, subangular to subrounded shapes. Type I clasts at the base of the formation tend to be more vesicular than those at the top of the formation.

Type II pumice clasts occur within the interior of the Pah Canyon Tuff. They are vitric, nondeformed, frothy or, rarely, silky with elongate tubes. These clasts contain from 5 to 7 percent crystals of feldspar, subordinate biotite, and rare pyroxene. Clots of blocky feldspar or feldspar and biotite are common and distinctive. Type II clasts have lower estimated feldspar/biotite ratios and higher estimated biotite/pyroxene ratios than type I clasts. Frothy clasts vary from light pinkish brown to dark yellowish orange; silky clasts are typically shades of yellowish orange to pale grayish orange. Type II clasts are equant to ellipsoidal (2:1) and subrounded to rounded.

Type II-cv pumice clasts are a variant of type II clasts and also occur within the interior of the Pah Canyon Tuff. They contain the same distinctive crystal clots but are distinguished from other type II clasts by a coarsely vesicular texture. Type II-cv clasts have thicker glass septa between vesicles, creating darker colors that vary from dark gray to dusky yellowish brown to pale yellowish brown to dark yellowish orange.

In general, type I pumice clasts decrease in amount and size downward, overlapping with the first appearance of type II clasts. Type II-cv clasts are present in the lower part of the formation, where they occur with type II clasts. Type I clasts reappear in the lowest few meters of the formation. 
Table 5. Depths to possible flow-unit boundaries in the Pah Canyon Tuff

[Pumice types are described in the text. $v=$ contact identified from video of unstaged core. $?=$ contact not identified or not recovered. N.P. $=$ unit is not present. Ranges are indicated where large intervals were not recovered. Solid lines indicate depths to top of pumice swarms or changes in pumice types. All depths given in meters. All correlations are tentative]

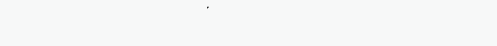

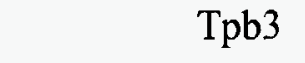
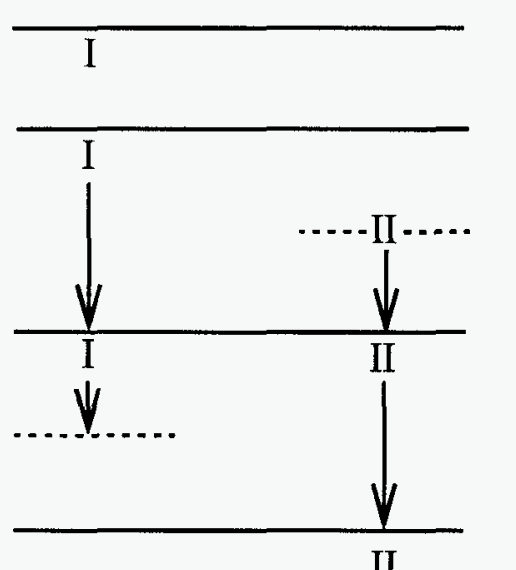

-swarm

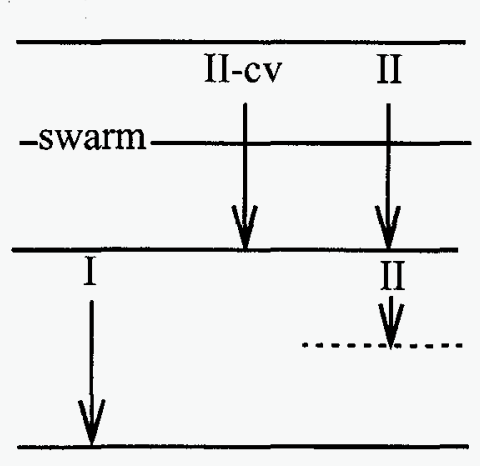

Tpbt2

\begin{tabular}{lllllllllll}
\hline UZ-14 & NRG-7/7A & SD-9 & NRG-6 & UZ-N371 & UZ-N31 & UZ-N32 & NRG \#4 ${ }^{2}$ & NRG \#2B & a\#5 & a\#7 \\
\hline 31.1 & $53.7^{*}$ & 47.7 & 53.3 & 45.2 & 36.5 & $39.6 \pm 0.1$ & $116.1 \pm 0.1$ & 87.0 & 356.5 & $69.0 \pm 0.3$
\end{tabular}

\begin{tabular}{|c|c|c|c|c|c|c|c|c|c|c|}
\hline 31.7 & $53.9 ?$ & $?$ & $55.2 \pm 0.1$ & $?$ & $?$ & 40.2 & $?$ & $?$ & 58.5 & 69.5 \\
\hline 34.4 & 55.9 & 49.7 & 55.5 & $47.1-50.7$ & $?$ & 41.2 & $?$ & 92.0 & $?$ & $?$ \\
\hline 35.9 & 56.8 & $?$ & 56.5 & $?$ & 39.0 & 42.3 & $?$ & 93.0 & $?$ & $?$ \\
\hline 37.5 & 59.9 & 52.1 & $57.4-60.9$ & $?$ & 41.1 & $?$ & 127.5 & $?$ & $60.7 ?$ & $72.2 ?$ \\
\hline 38.6 & 62.8 & 56.8 & $?$ & $?$ & 42.3 & $?$ & $?$ & $?$ & 62.6 & 80.5 \\
\hline 39.9 & N.P.? & $?$ & $?$ & $?$ & $?$ & $?$ & $?$ & $?$ & 64.0 & \\
\hline 47.4 & 69.0 & 63.8 & $61.1-62.9$ & 53.7 & N.P. & N.P. & $128.1 \pm 0.1$ & N.P. & N.P. & \\
\hline$?$ & 72.5 & 64.8 & N.P.? & 59.1 & N.P. & N.P. & $130.0 ; 133.4$ & N.P. & N.P. & \\
\hline 69.4, & 76.5 & 67.2 & $65.1-65.3$ & 64.4 & 42.5 & 46.9 & $?$ & $96.9 ?$ & 69.5 & \\
\hline 72.2 & 77.5 & $68.2 \pm 0.1$ & 65.5 & $64.8 \pm 0.05$ & 43.1 & 47.1 & $>127.5$ & $?$ & 69.9 & \\
\hline 73.3 & 78.8 & $69.1 \pm 0.2$ & 67.3 & 66.9 & 44.0 & 48.3 & 139.6 & 98.8 & 70.4 & 81.3 \\
\hline
\end{tabular}

$19.9 \mathrm{~m}$ (45 percent) of Tpp interval was not recovered.

${ }^{2}$ No recovery from 118.4 to $126.4 \mathrm{~m}$; pumice texture obscured by alteration below $137.8 \mathrm{~m}$. Contains two swarms of types II and II-cv pumice.

${ }^{3}$ First core recovered in Tpp.

${ }^{4}$ Not corrected for borehole slant of $26^{\circ}$. Pumice types cannot be distinguished below $80.5 \mathrm{~m}$ due to alteration. 
Alteration and devitrification destroy the character of pumice clasts and diminish the ability to distinguish pumice types. In boreholes where alteration has destroyed primary glass (for example, NRG \#2B), it is often possible to identify distinctive crystal clots within remnant type II clasts. Altered or partially altered pumice clasts occur in shades of pinkish gray, grayish orange, light gray, or white. Devitrified pumice clasts are pale to moderate brown or shades of grayish orange-pink.

Outcrops along Solitario Canyon cliff contain exposures of distal Pah Canyon Tuff (appendix 2). In these locations, the formation comprises one or more flow units composed of coarse pumice blocks enclosed in a fine-grained matrix. Pumice blocks have diameters to $200 \mathrm{~mm}$ as far south as measured section PTn\#11 (fig. 1), where they are reversely graded in a crude manner (fig. 18A). In other locations (PTn\#5 and \#6; fig. 1), pumice blocks occur in lenticular, clast-supported horizons. Both type I and type II pumice clasts are present.

In outcrops south of Yucca Wash, the Pah Canyon Tuff varies from nonwelded and vitric to moderately welded and devitrified. Moderately welded zones, which are resistant to erosion, form cliffs (fig. 18B) composed of devitrified tuff. Exposures near Sever Wash of the upper nonwelded, vitric Pah Canyon Tuff contain numerous swarms of pumice that mark probable flow-unit tops (fig. 18C).

The upper contact of the Pah Canyon Tuff is sharp and locally irregular. An abrupt color change marks the contact where pinkish-gray pyroclastic-flow material is overlain by a light-gray pumice-fall deposit identified as unit $A$ of the pre-Yucca Mountain Tuff bedded tuffs. The upper 30 to $60 \mathrm{~cm}$ of the Pah Canyon Tuff may be reworked as indicated by abrupt, local decreases in the amount and sizes of pumice clasts, incipient alteration of matrix, and change to more brownish colors.

The lower contact of the Pah Canyon Tuff is sharp and locally irregular. This contact also appears as an abrupt color change at which lightgray pyroclastic-flow material overlies a brown, possibly reworked, unit identified as unit $D$ of the pre-Pah Canyon Tuff bedded tuffs. In some locations, the lowest few centimeters of Pah Canyon Tuff are fine-grained tephra that may represent a basal layer (see Cas and Wright, 1987, p. 188).

\section{Formation Distribution, Thickness, and Correlation}

The Pah Canyon Tuff erupted from a source within the Claim Canyon caldera (Byers and others, 1976). An isochore map of Pah Canyon Tuff thickness developed from borehole data in the Yucca Mountain region by Buesch, Nelson, and others (in press) depicts a gradual southward decrease in deposit thickness. Figure 19 shows a similar configuration determined from boreholes and measured sections in this study. Although reconnaissance observation of the Pah Canyon Tuff in the Yucca Wash region suggests that the formation has a distribution that may be partly controlled by pre-eruption topography (fig. 18D), the magnitude of paleotopographic control is unknown.

Abrupt changes in the sizes and amounts of pumice clasts within the Pah Canyon Tuff may mark possible flow-unit boundaries that could serve as a basis for correlation within the formation. The overlapping distal flow lobes of the pyroclastic-flow deposits formed during the May 18, 1980, eruption of Mount St. Helens contain variably thick swarms of pumice, separated by deposits of less pumiceous pyroclasticflow material (Rowley and others, 1981; their figs. 296 and 297). The swarms of pumice observed within the Pah Canyon Tuff in core and outcrop suggest that the Mount St. Helens deposits may serve as a useful analog to these pumiceous deposits. Tables 4 and 5 give the depths to possible flow-unit boundaries within the Pah Canyon Tuff as identified by pumice swarms and changes in the types of included pumice clasts. Note that all unit correlations are tentative. Due to the character and distribution of pumice flow lobes, units depicted as correlative on tables 4 and 5 may or may not represent the same flow unit (refer to figures 296 and 297 of Rowley and others, 1981).

With the exception of pumice clasts, there are few reliable criteria to distinguish flow units. One observation that appears consistent in core is that the flow units containing type II-cv pumice clasts are comparatively coarse grained. These flows have abundant, submillimeter-sized, glassy pumiceous chunks, glass shards that have platy, curviplanar, or cuspate shapes, crystal contents of 7 to 10 percent (locally 10 to 15 percent), and lithic contents that vary from 3 to 5 percent to 7 to 10 percent (lithic clasts are typically smaller than $10 \mathrm{~mm}$ ). 


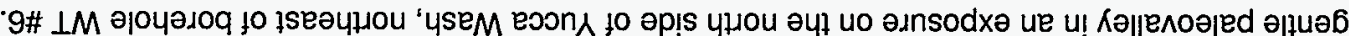

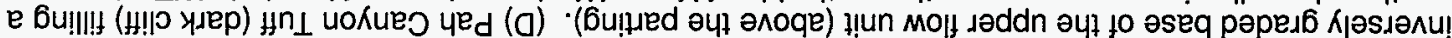

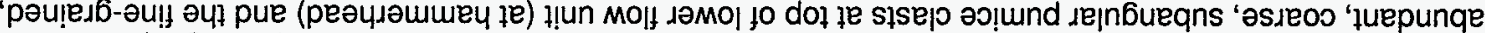

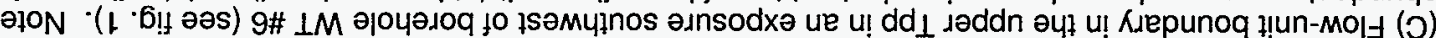

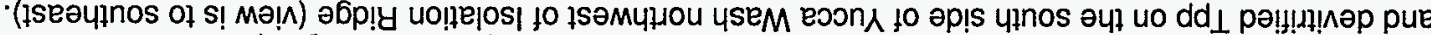

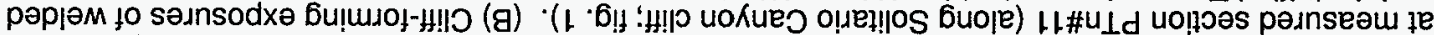

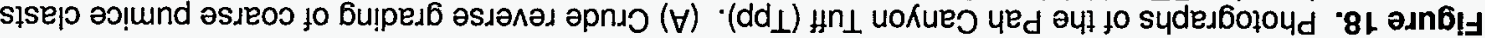
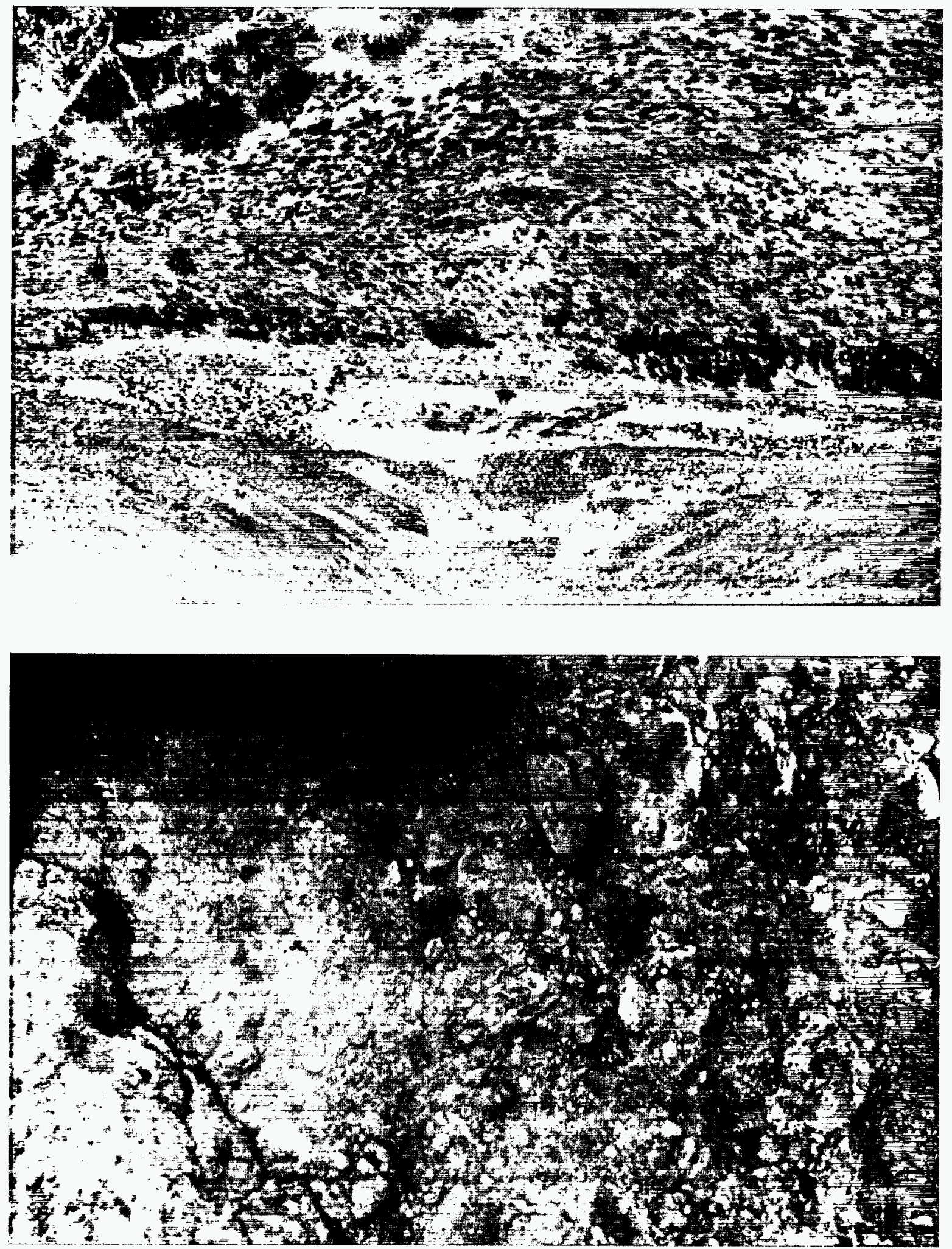


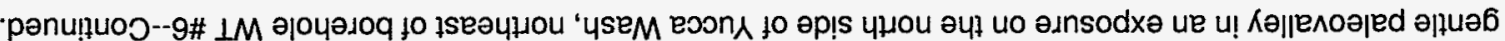

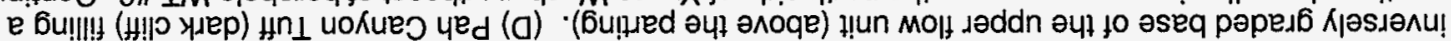

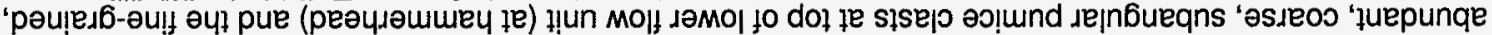

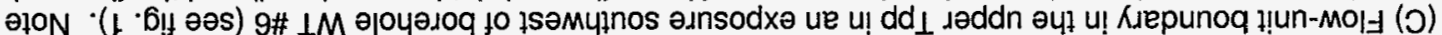

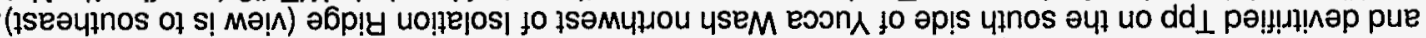

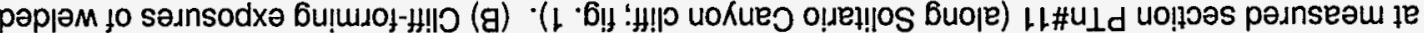

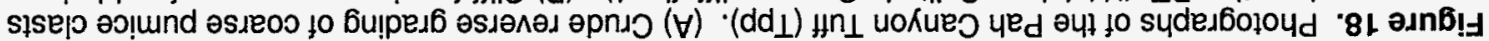
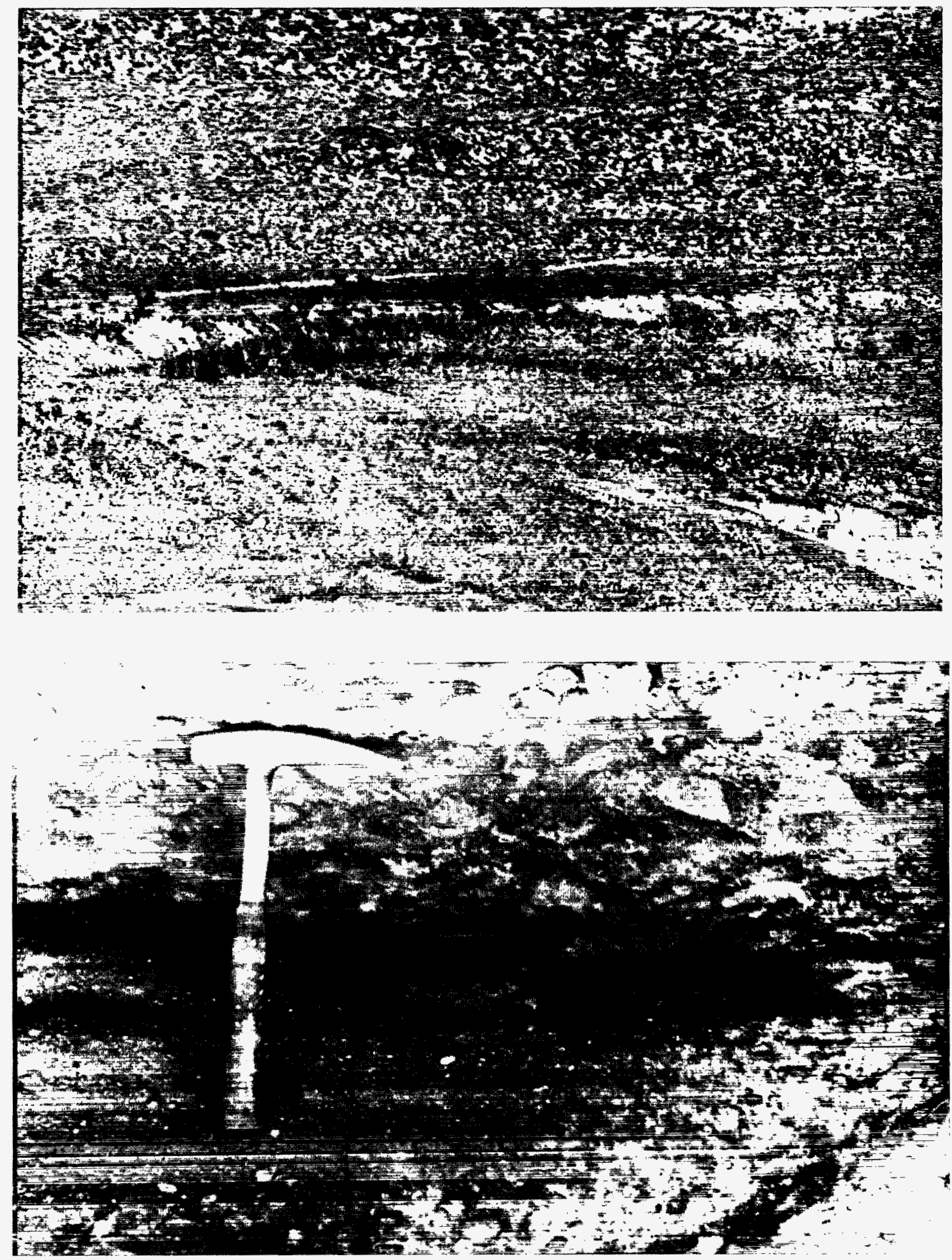


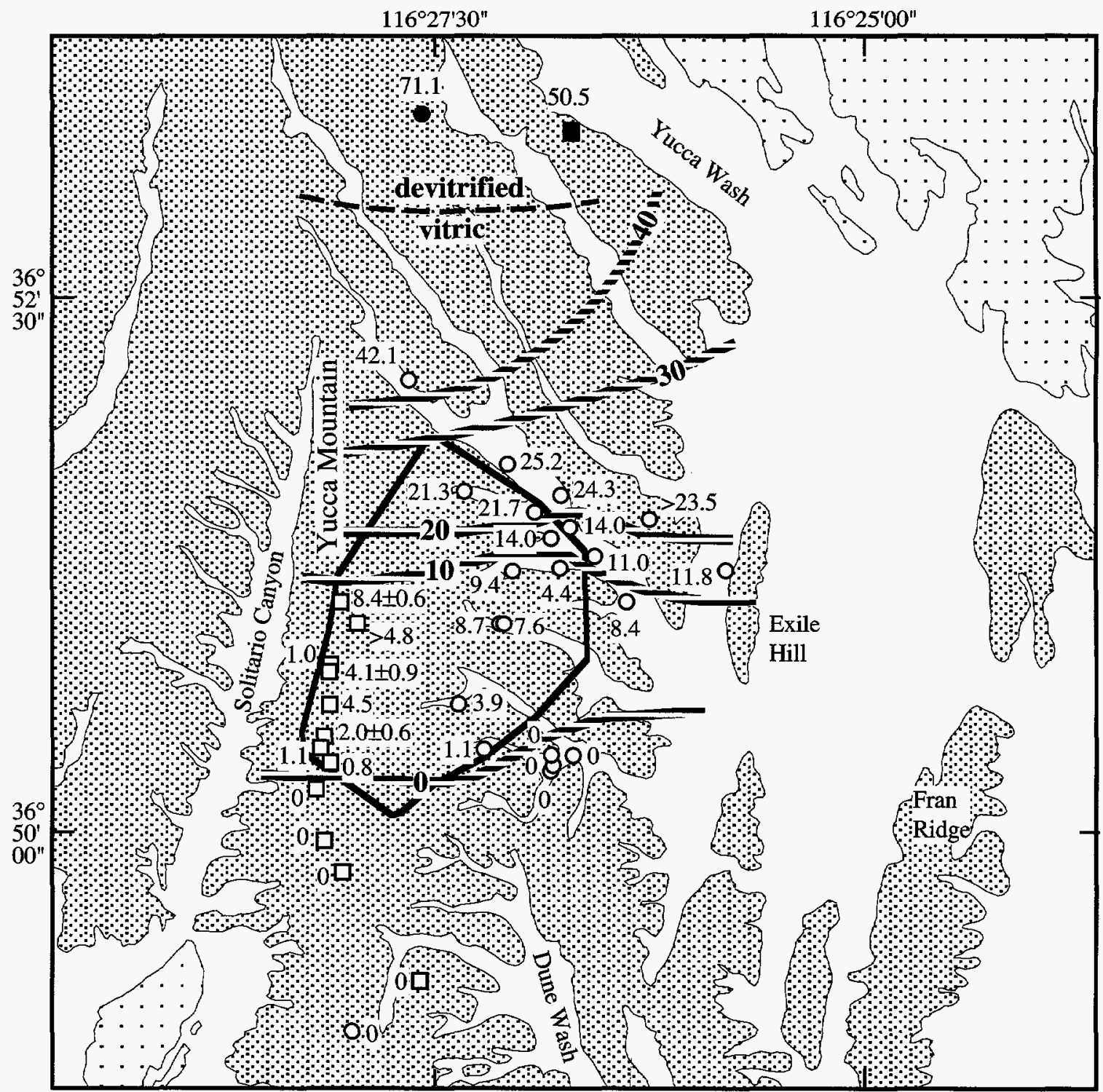

\section{EXPLANATION}

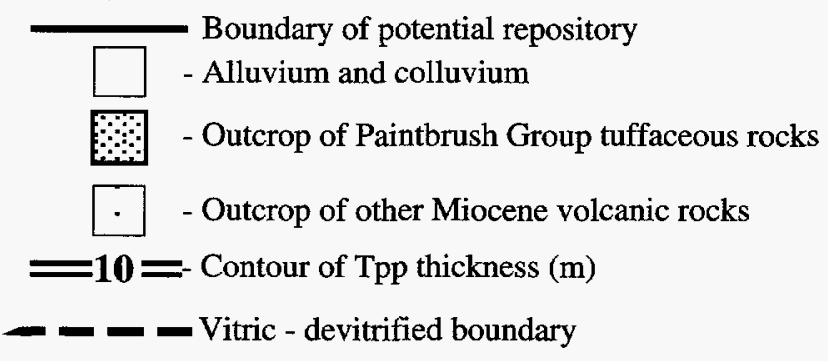

$50.5 \quad-$ Measured section location and Tpp thickness (m); open=vitric, filled=devitrified

- Borehole location and Tpp thickness (m); open=vitric; filled=devitrified

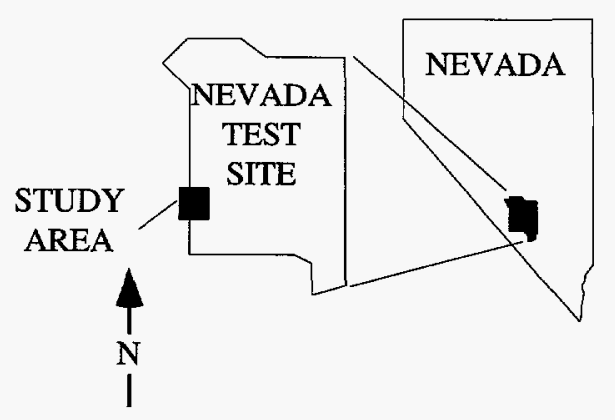

Figure 19. Apparent thickness of the Pah Canyon Tuff (Tpp) in cored boreholes and measured sections. Borehole thicknesses are uncorrected for deviation from vertical; borehole a\#7 (see fig. 1) is corrected for inclination of $26^{\circ}$. 
A possible flow break that occurs at $158.2 \mathrm{~m}$ in borehole G-2 is marked by an abrupt increase in the percentage of crystals and lithic clasts. Borehole G-2 also contains a thin (few millimeters), clast-supported, crystal-lithic-pumice-rich fall horizon at $213.5 \mathrm{~m}$ that is not present in other boreholes and that has not been observed in exposures.

\section{Features of Welding, Secondary Crystallization, and Alteration}

The Pah Canyon Tuff forms a simple cooling unit in the Yucca Mountain region (Christiansen and Lipman, 1965; Caporuscio and others, 1982; Maldonado and Koether, 1983; Scott and Bonk, 1984) but is a compound cooling unit in locations northwest of the study area (Fridrich and others, in press). The deposit, which is nonwelded and vitric to locally altered throughout most of the Yucca Mountain region, is welded, devitrified, and vapor-phase altered in exposures and boreholes near Yucca Wash, where the formation thickens appreciably. Petrographic studies of Pah Canyon Tuff samples recovered from borehole G-2 (Caporuscio and others, 1982) found argillic alteration of matrix ash in the vitric, upper part of the formation, heulandite mineralization in the central welded zone, and scattered amounts of zeolite mineralization in the central and lower parts of the formation. Broxton and others (1994) also reported clay and zeolite alteration in outcrop samples from the Yucca Wash region.

Table 6 summarizes vertical variations in welding, secondary mineralization, and alteration observed in core from borehole $\mathrm{G}-2$, the only borehole that was cored through welded Pah Canyon Tuff. Note that the downward variations in the degree of welding and secondary mineralization are gradational changes; the contacts listed in table 6 are located where these features become the primary characteristic of the rock.

The rock matrix of Pah Canyon Tuff is granular and nondeformed in the upper part of the formation in borehole $\mathrm{G}-2$ (table 6 ). This interval is underlain by a thin $(60 \mathrm{~cm})$ silicified zone below which the matrix appears compacted, deformed, and less porous. Matrix porosity decreases (and rock density increases) downward, then becomes relatively consistent before gradually increasing in the lower part of the formation. The matrix is moderately welded at its maximum and is never welded to the degree that porosity is eliminated. A plot of mean pumice shape ratios, computed from 8 to 12 measurements of major and minor pumice axes at depth increments of approximately $1.5 \mathrm{~m}$, illustrates the welding profile (fig. 20A).

Table 6 summarizes changes observed in the alteration and crystallization of pumice clasts and matrix in the Pah Canyon Tuff in borehole G-2. Pumice alteration and devitrification textures are zoned symmetrically with depth in the Pah Canyon Tuff; in most cases, textural changes are gradational. Pumice clasts are vitric to partially altered (iron stained or slightly argillized) in the upper part of the formation. A thin $(1.3 \mathrm{~m})$ zone of argillically altered pumice clasts separates vitric clasts from clasts that have been replaced by linear chains of milky spherules (microspherulites) that are coated with vapor-phase tridymite or cristobalite. Microspherulitic devitrification gives way downward to more coarse-grained devitrification in which spherulites appear as radial sprays of needlelike crystals that crosscut pumice textures and in which clast margins appear axiolitically devitrified. Spherulitic textures diminish downward as pumice clasts assume a sugary texture, with few obvious spherulites or axiolites; minor vapor-phase crystallization locally is present in this zone. These zones reappear downward in reverse order, as shown in table 6.

Devitrification of nondeformed glass shards and matrix ash occurs over an interval of $1.4 \mathrm{~m}$ (table 6). An abrupt change from devitrified to devitrified/silicified matrix is characterized by a loss of matrix texture and porosity and the development of a cherty fracture habit. Below the silicified zone, matrix porosity and texture return, and the matrix is altered by vapor-phase mineralization. The intensity of vapor-phase alteration diminishes downward as porosity decreases. In the central portion of the Pah Canyon Tuff, the matrix is pervaded by minute, blocky, euhedral, colorless crystals identified as heulandite by Caporuscio and others (1982, p. 22). Slight alteration of shards and matrix begins within the zone of heulandite mineralization and becomes more prevalent downward until the matrix becomes argillically altered. Matrix texture is variably preserved in the argillic zone, and where present, the matrix appears partially welded. Pale greenish-yellow alteration occurs as submillimeter halos around some biotite and iron oxide phenocrysts in the lower $1.5 \mathrm{~m}$ of the argillic zone. Below this interval, the matrix contains glassy, pumiceous chunks and platy to curviplanar glass shards with local grayish-yellow alteration that occurs as submillimeter rims on iron oxide phenocrysts. 
Table 6. Depths to depositional, welding, and crystallization features in the Pah Canyon Tuff-borehole USW G-2

[Pumice types are described in text. ? = uncertain contact. All depths given in meters]

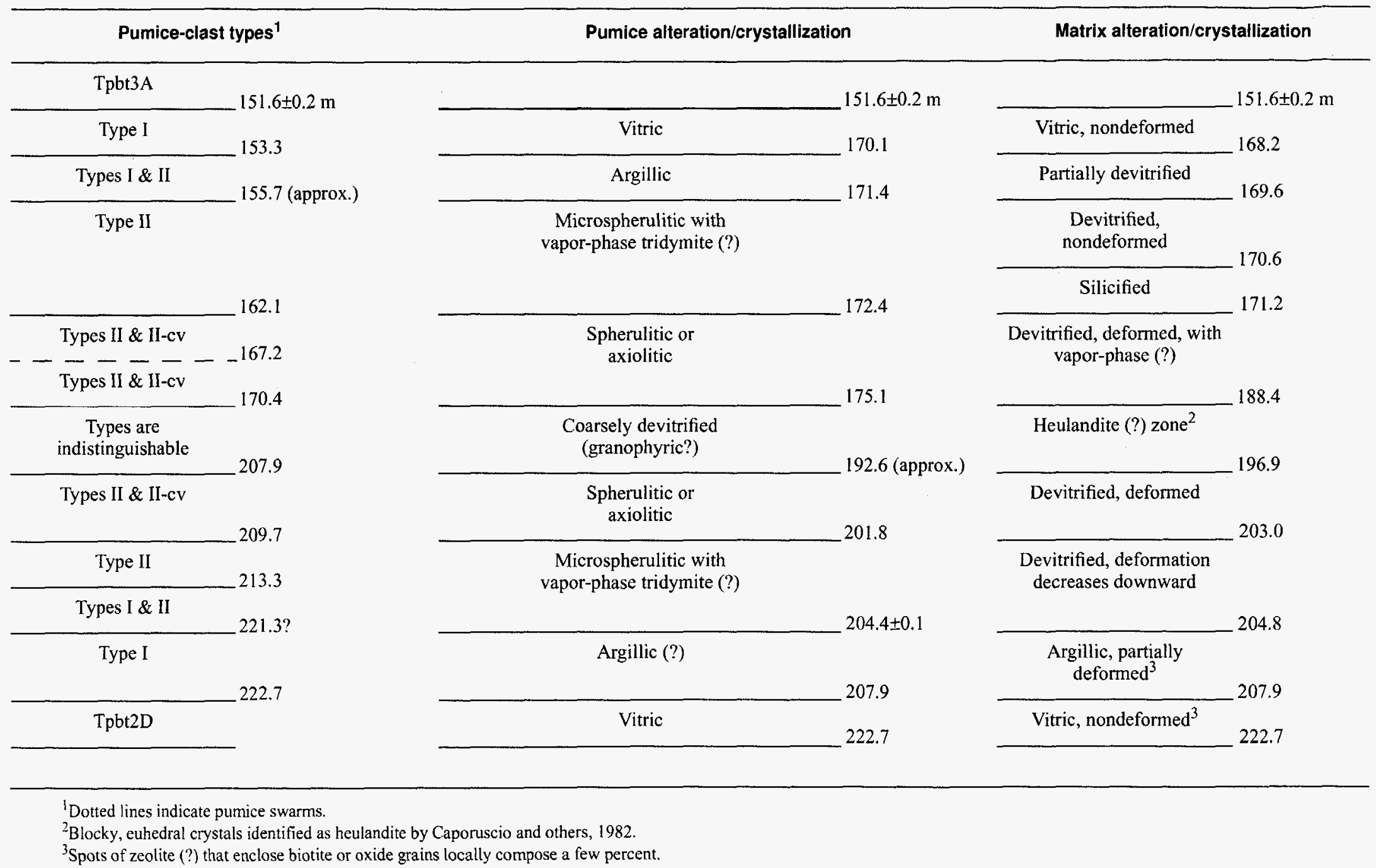




\section{Borehole USW G-2}

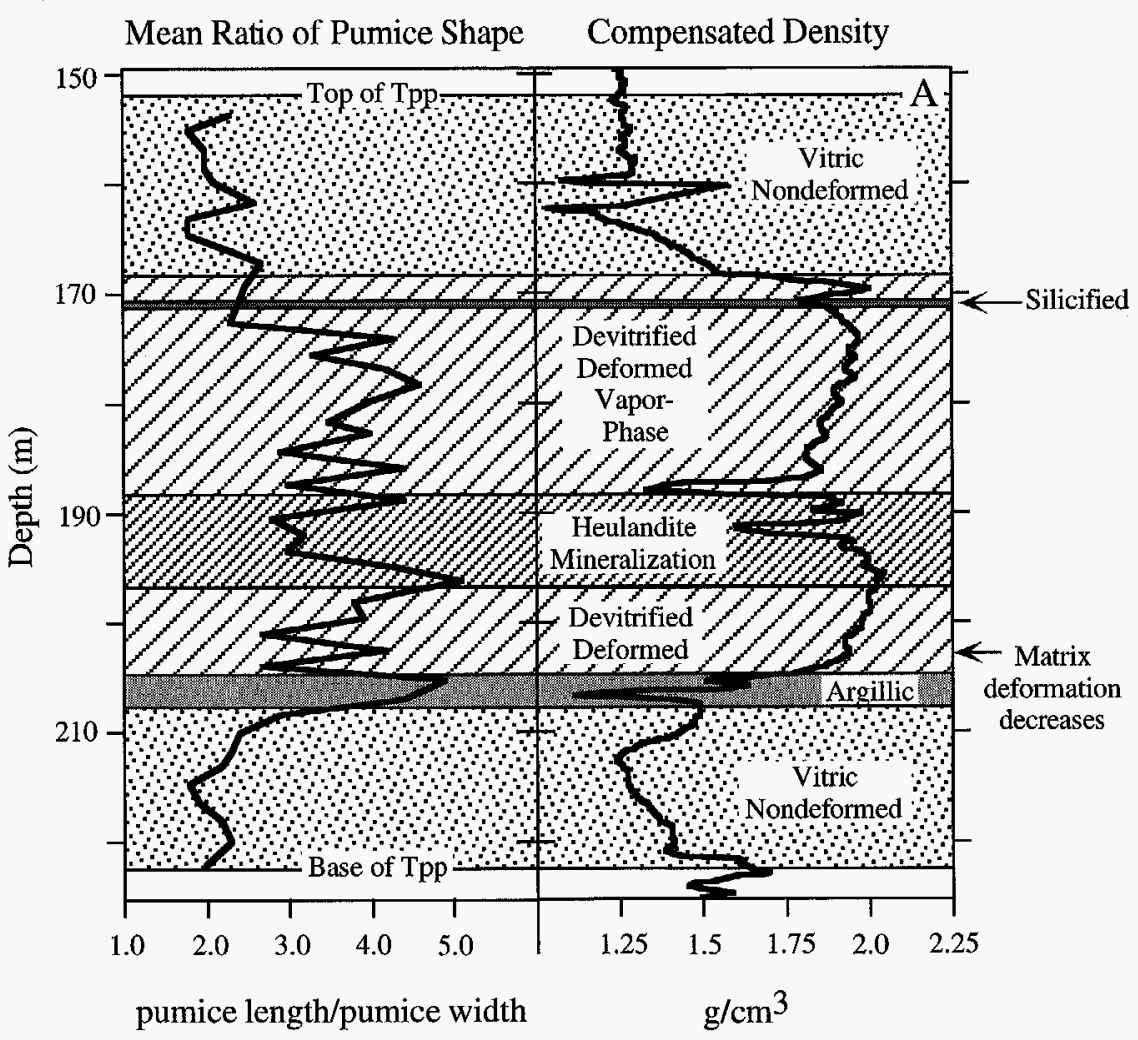

Borehole UE-25 NRG \#4

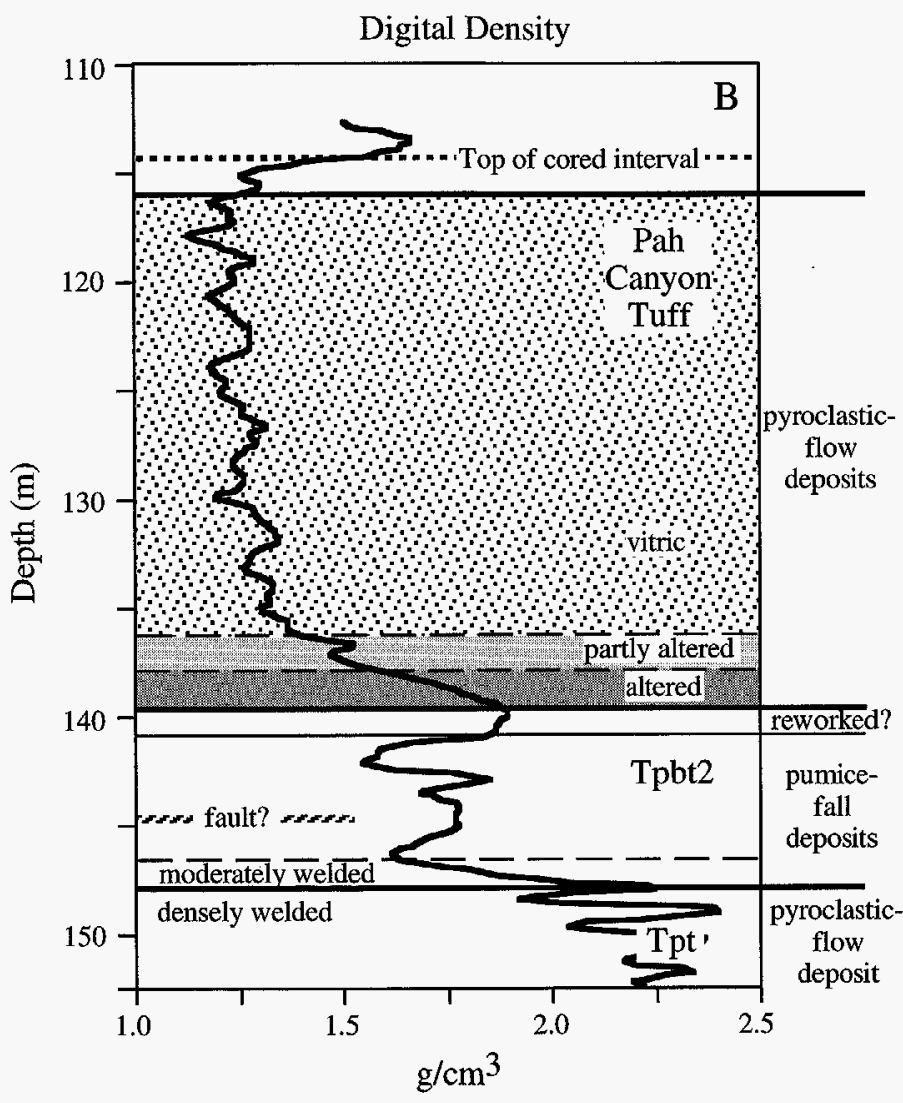

Figure 20. (A) Mean ratios of pumice shape and compensated density measured in the Pah Canyon Tuff (Tpp) plotted relative to drilled depth in borehole G-2. Pumice flattening ratios are mean of 8 to 12 measurements within core intervals of 30 centimeters or less. Standard deviation on mean analysis is typically 0.5 to 2.0. Compensated density log from Nelson and others (1991). Lithologic contacts are given in table 6.

(B) Digital density log plotted relative to depth in borehole NRG \#4. Lithology is described in text. Digital density data are from L.E. Thompson, Science Applications International Corporation (written commun., 1995). 
Pyroxene phenocrysts are altered to lime green pseudomorphs from 191.1 to $205.7 \mathrm{~m}$ in borehole G-2; they are dark green and unaltered elsewhere. Biotite phenocrysts, which are fresh to partially oxidized in most of the deposit, are strongly oxidized and bronze colored in this same interval.

The Pah Canyon Tuff is nonwelded and variably altered in boreholes NRG \#4, NRG \#2B, a\#1, a\#5, and a\#7. Nonwelded Pah Canyon Tuff changes downward from vitric to zeolitically altered in borehole NRG \#4. The effects of alteration are apparent beginning at about $136.2 \mathrm{~m}$ and continue beneath the base of the formation. High-angle fractures crosscut the core from about 136.5 to about $137.0 \mathrm{~m}$; high-angle fractures with slickensides are noted in the underlying interval at $144.6 \mathrm{~m}$ (fig. $20 \mathrm{~B}$, see next section).

Alteration destroys the texture of the rock matrix and included pumice clasts in borehole NRG \#4.

Above $136.9 \mathrm{~m}$, the rock matrix is composed of granular, vitric ash that encloses sparse glass shards. From 136.9 to $137.8 \mathrm{~m}$, alteration gradually destroys the character of the matrix ash and, eventually, the integrity of the glass shards. Matrix texture is obliterated below $137.8 \mathrm{~m}$ and millimeter-sized spots of manganese oxide are common within the matrix. Rock density increases significantly from 137.2 to $137.8 \mathrm{~m}$, coincident with alteration of the rock matrix (fig. 20B). Pumice clasts are vitric and very light gray to pinkish gray above $137.9 \mathrm{~m}$, but altered and shades of orangepink or pinkish gray below. Alteration does not obviously affect phenocrysts and lithic clasts in borehole NRG \#4.

The Pah Canyon Tuff is altered throughout its cored interval in borehole NRG \#2B. Matrix color varies downward from pinkish gray to pale orange-pink to very pale orange. Remnant shard textures are variably, but generally poorly, preserved, and the rock has a "chalky" texture. Pumice clasts are difficult to discern because their colors are similar to that of the rock matrix but can be identified by the presence or absence of crystal clots. Lithic clasts and phenocrysts show effects of alteration: moderate reddish-brown, glassy lithic clasts are replaced by altered clasts of similar color, and biotite crystals locally are oxidized and appear bronze.

\section{Pre-Pah Canyon Tuff Bedded Tuffs (Tpbt2) and Non- to Partially and Moderately Welded Subzones of the Topopah Spring Tuff Crystal-Rich Vitric Zone (Tptrv3; Tptrv2)}

The PTn interval from the base of the Pah Canyon Tuff and the top of the crystal-rich vitrophyre of the Topopah Spring Tuff includes the pre-Pah Canyon Tuff bedded tuffs (Tpbt2) and the non- to partially welded (Tptrv3) and moderately welded subzones (Tptrv2) of the crystal-rich vitric zone of the Topopah Spring Tuff (Buesch, Spengler, and others, 1996) (fig. 2). This interval, which is divided into four informal stratigraphic units, contains two marker horizons (designated ash layers 1 and 2) and a (possibly) reworked zone that can be correlated between boreholes and field exposures. The three stratigraphically lowest units are pumiceous fallouts that are distinguished by color; the stratigraphically highest unit is the reworked zone.

Buesch, Spengler, and others (1996) noted that the top of the Topopah Spring Tuff is not defined explicitly and tentatively designated ash layer 1 as the contact between the non- to partially welded subzone of the Topopah Spring Tuff crystal-rich zone (Tptrv3) and the overlying pre-Pah Canyon Tuff bedded tuffs (Tpbt2). This places the upper contact of the Topopah Spring Tuff within a sequence of macroscopically similar pumice-fall deposits. The informal unit designations defined herein will be used in favor of Buesch, Spengler, and others' nomenclature until the ambiguous formation contact can be definitively located.

Twelve cored boreholes drilled since 1991 contain comparatively complete stratigraphic sections of this PTn interval. Partial sections were recovered in boreholes NRG \#4 and UZ-N55, where it is presumably thinned by faulting; the interval was poorly recovered in borehole SD-7. The interval is vitric to variably altered in all post-1991 cored boreholes except NRG \#4, where it is pervasively altered. This interval also occurs in eight older cored boreholes in which it is vitric to variably altered. A partial section was recovered in borehole a\#1, where it is thinned, presumably by faulting.

These stratigraphic units were examined in outcrops along Solitario Canyon cliff. Although the interval is only partially exposed in many locations, interval and unit thicknesses were measured in 10 stratigraphic sections (fig. 1; appendix 2).

Composite descriptions of the four units are presented below in descending stratigraphic order. 
Generalized Unit and Contact Descriptions

\section{Unit D}

Unit D is a matrix-supported, possibly reworked deposit that varies from pale yellowish brown to light brown (fig. 21A). The unit appears pale brown where locally altered. Typically, unit $D$ has a matrix of fine, vitric (?) ash; however, locally it is a mix of subrounded, sand-sized crystals and lithic clasts. Glass shards are absent. Pumice clasts commonly compose from 15 to 40 percent of the rock and typically are smaller than $20 \mathrm{~mm}$. Pumice clasts that are vitric, shades of light gray (grayish yellow where altered), microvesicular, and biotite-bearing compose from 70 to 90 percent of the total pumice. Less common moderate orange-pink clasts (typically this coloration occurs as a rind enclosing a lighter interior) are slightly altered; they appear light brown where strongly altered. These clasts are more abundant where the substrate is argillically altered, and they tend to become less abundant stratigraphically upward. Phenocrysts of feldspar and subordinate biotite compose from 10 to 20 percent of unit $\mathrm{D}$; pyroxene is rare to absent. Lithic clasts vary in abundance, but typically form 10 to 20 percent of the unit. Clasts, mostly smaller than $15 \mathrm{~mm}$, include grayish-black, feldspar-bearing glass and devitrified volcanic rock in shades of pale red to pale brown.

Unit D is a massive bed that generally lacks depositional features but that exhibits crude bedding in some exposures (fig. 21 A). A notable exception occurs at measured section PTn\#5 (fig. 1), where the interval from the base of Tpp to the top of Tptrvl is unusually thin. Here, the basal $35 \mathrm{~cm}$ of exposed unit $D$ is a cross-laminated, coarse sand, and the upper $20 \mathrm{~cm}$ is a coarse, pebbly sand with faint crossbedding (fig. 21B). A coarse, moderately sorted, immature, tuffaceous sandstone composes the lower part of unit $D$ in borehole $\mathrm{G}-2$. Preserved within unit $\mathrm{D}$ in four boreholes (NRG-6, UZ-N31, a\#1, and G-2) is a thin (about $10 \mathrm{~cm}$ ), clast-supported deposit of light-gray pumice. This deposit, which occurs approximately $60 \mathrm{~cm}$ below the upper contact of unit $\mathrm{D}$, has upper and lower contacts that are gradational over less than $6 \mathrm{~cm}$, suggestive of reworking. Unit D varies from 0.7 to $2.6 \mathrm{~m}$ thick in the Yucca Mountain region.

The upper contact of unit D is depositional, sharp, and locally undulatory. In most locales, the unit is overlain by light-gray to white or grayish-orangepink to pale yellowish-brown, nonwelded, pumiceous, pyroclastic-flow material of the Pah Canyon Tuff.
In southern locations where the Pah Canyon Tuff is absent, unit $\mathrm{D}$ is overlain by the basal pumice-fall deposit (unit A) of the pre-Yucca Mountain Tuff bedded tuffs, which is composed of light-gray, nonwelded, vitric pumice clasts.

\section{Unit C}

Unit $\mathrm{C}$ is a variably altered, clast-supported, pumice-fall deposit that contains an ash-bed marker horizon designated "ash layer 2." The deposit may appear matrix supported where pumice-clast margins are indistinct. The unit is moderately sorted; it is notably uniform in sorting and grain size except in the upper $15 \mathrm{~cm}$ of the deposit, which is a sequence of several well-sorted, poorly indurated fallouts, and locally below ash layer 2 , where grain size and sorting decrease slightly. This unit typically is very pale orange to white, but locally has the light-brown coloration of unit B, and it may occur in shades of moderate red where argillically altered near the upper contact.

Matrix ash generally occurs in shades of very pale orange to white. Pumice clasts, which compose 65 to 85 percent of the rock, are shades of very pale orange to white where vitric and unaltered, but may be white, grayish yellow, or light brown where altered. Hydrothermal (?) alteration locally occurs along clast margins or within the matrix, especially in the upper 1 to $2 \mathrm{~m}$ of the deposit, imparting a moderate reddishbrown stain. Pumice clasts, which contain crystals of feldspar, minor biotite and iron-titanium oxides, and rare pyroxene, generally have diameters of 10 to $30 \mathrm{~mm}$. Phenocrysts of feldspar, subordinate biotite and minor iron-titanium oxides, and pyroxene compose from 5 to 10 percent of the unit. Lithic clasts typically compose from 3 to 7 percent of the rock. Clast types include grayish-black, biotite- and feldspar-bearing glass; devitrified volcanic rock in shades of moderate red to light red and pale red to light gray; glassy, biotite- and feldspar-bearing tuff in shades of moderate yellowish brown to light red; grayish-orange-pink, feldspar- and biotite-bearing, hydrated glass; and lightgray, finely crystalline (cognate?) subvolcanic rock Clasts of devitrified volcanic rock tend to be more abundant below ash layer 2, although clast types are generally similar throughout. Unit $\mathrm{C}$ ranges from 1.9 to $8.0 \mathrm{~m}$ thick in the Yucca Mountain region. 

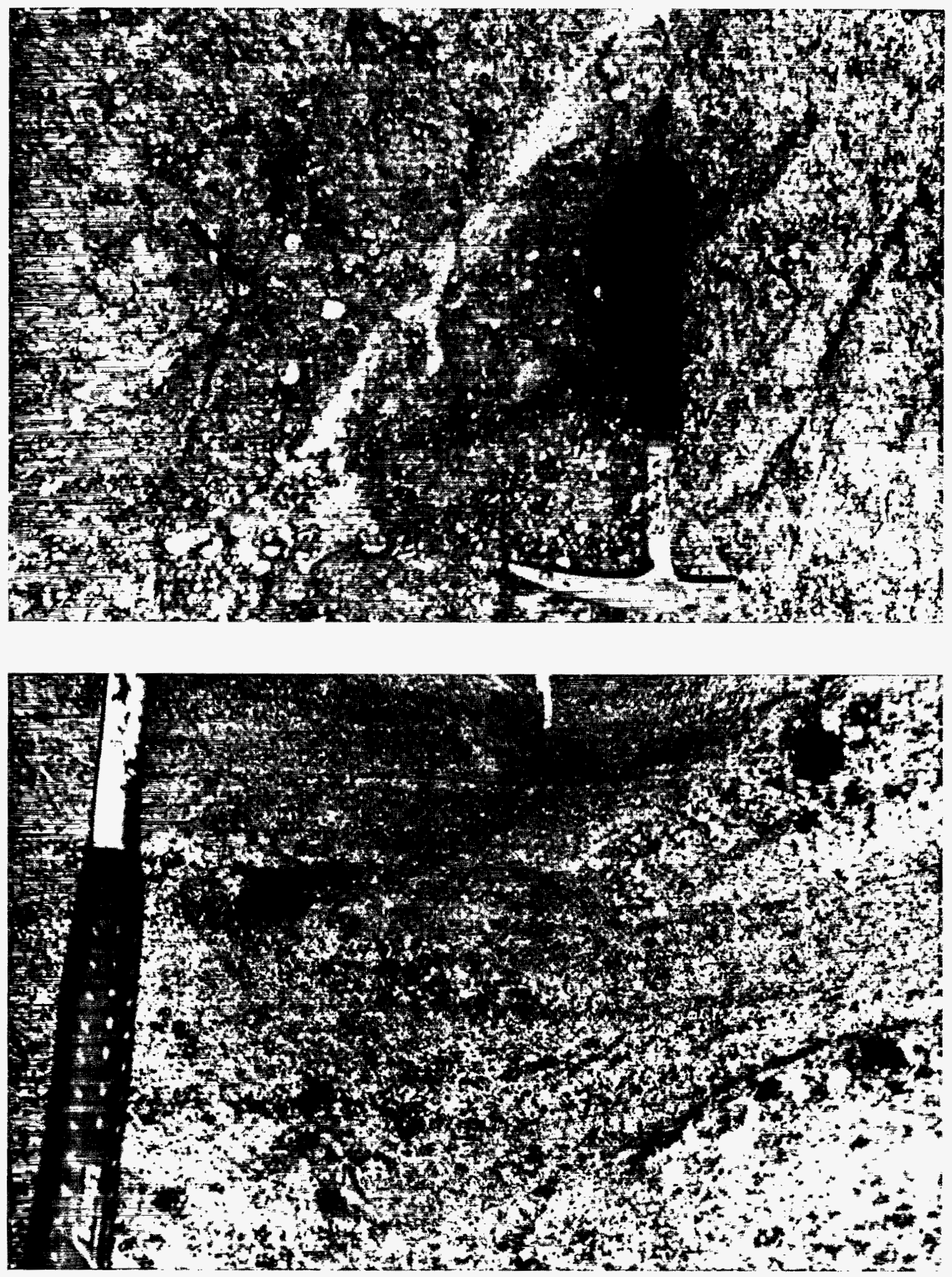

Figure 21. Photographs of pre-Pah Canyon Tuff bedded tuffs (Tpbt2). (A) Photograph of massive unit D at measured section PTn\#8 (Solitario Canyon cliff; fig. 1). (B) Laminated, pebbly sandstone in unit D exposed at measured section PTn\#5 (Solitario Canyon cliff; fig. 1). (C) Ash layer 1 preserved in core from borehole SD-9 at 77.8-meter depth. (D) Moderately welded, deformed pumice-fall deposit of unit A (Tptrv2) exposed along Solitario Canyon cliff, north of measured section PTn\#8 (fig. 1).

48 Stratigraphic Relations and Hydrologic Properties of the Paintbrush Tuff Nonwelded (PTn) Hydrologic Unit, Yucca Mountain, Nevada 

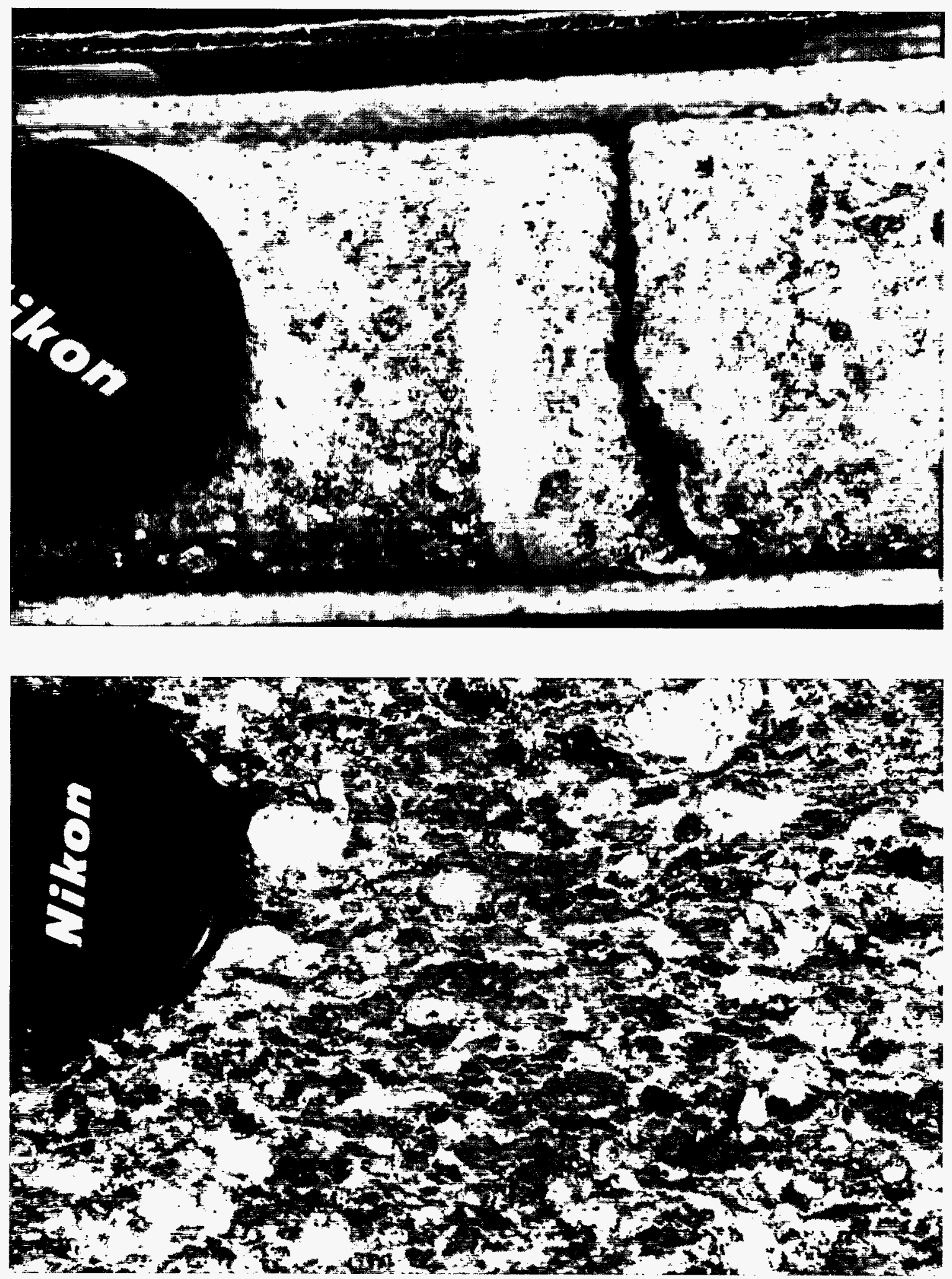

Figure 21. Photographs of pre-Pah Canyon Tuff bedded tuffs (Tpbt2). (A) Photograph of massive unit D at measured section PTn\#8 (Solitario Canyon cliff; fig. 1). (B) Laminated, pebbly sandstone in unit D exposed at measured section PTn\#5 (Solitario Canyon cliff; fig. 1). (C) Ash layer 1 preserved in core from borehole SD-9 at 77.8-meter depth. (D) Moderately welded, deformed pumice-fall deposit of unit A (Tptrv2) exposed along Solitario Canyon cliff, north of measured section PTn\#8 (fig. 1)--Continued. 
Unit $\mathrm{C}$ is a massive deposit that locally exhibits crude layering in the upper few meters of weathered surfaces. Other depositional features observed in only a few boreholes include a 10 - to 25 -mm-thick, light-gray to white ash layer (boreholes NRG \#4 and $\mathrm{NRG}-7 / 7 \mathrm{~A}$ ) and a 12-cm-thick, light-gray to white pumice horizon (borehole SD-12).

Ash layer 2 is composed of a basal, grayishpink to grayish-orange-pink ash, typically 12 to $20 \mathrm{~mm}$ thick, that underlies approximately $5 \mathrm{~mm}$ of clastsupported, lithic-rich fallout. The lithic-rich fall is composed of about 20 percent vitric pumice clasts, 10 to 20 percent crystals, and 60 to 70 percent lithic clasts. Pumice clasts are white to very pale orange and typically from 1 to $4 \mathrm{~mm}$ in diameter. Phenocrysts include feldspar, minor fresh to partially oxidized biotite, and rare pyroxene. Lithic clasts, typically from 1 to $4 \mathrm{~mm}$ diameter, include moderate red devitrified volcanic rock, light-brown, feldspar-bearing glass, and grayishblack glass.

The contact between units $\mathrm{C}$ and $\mathrm{D}$ is depositional and sharp. The character of unit $\mathrm{C}$ immediately below the contact varies depending on the presence or absence of argillic alteration (see below).

\section{Unit B}

Unit B is an altered, clast-supported, pumice-fall deposit that contains an ash-bed marker horizon designated "ash layer 1" (fig. $21 \mathrm{C}$ ). The unit is moderately sorted and has a variable grain-size and lithic content, especially below ash layer 1 , where the ratio of devitrified to glassy lithic clasts increases abruptly. Unit B is predominantly light brown with scattered light-gray pumice clasts. Indistinct pumice-clast margins, which create the appearance of matrix support, are a characteristic feature of this unit.

Unit B contains little to no matrix. Pumice clasts, which typically compose 80 percent of the unit, have a frothy texture, are nonwelded and vitric to altered. Altered clasts, which form most of the pumice population, are light brown and 10 to $35 \mathrm{~mm}$ in diameter. Vitric to slightly altered clasts compose 10 to 15 percent of the pumice population; these clasts generally are light gray to white and from 10 to $20 \mathrm{~mm}$ in diameter. The unit contains phenocrysts of feldspar, subordinate biotite and pyroxene, and minor irontitanium oxides. Crystal content increases downward from 5 to 10 percent of the unit to 5 to 25 percent (gen- erally greater than 10 percent) of the unit at the point where the lithic assemblage is dominated by devitrified clasts. Lithic clasts generally compose from 7 to 10 percent of the unit, but locally may approach 15 to 25 percent. Clasts of feldspar- and biotite-bearing glass, common in the upper part of the unit but rare to absent in the lower part, are either grayish black or light brown. Clasts of pale to moderate red or grayish-red to medium light-gray devitrified volcanic rock are ubiquitous and compose most of the lithic assemblage in the lower part of the deposit. Clasts of colorless glass; pale-brown devitrified volcanic rock; white, sugary, hypabyssal (?) rock; dark yellowish-brown, feldsparand biotite-bearing cognate (?) inclusions; and moderate pink, feldspar- and biotite-bearing tuff are a minor to rare component of the lithic assemblage. The subangular lithic clasts commonly have diameters of 5 to $10 \mathrm{~mm}$.

Unit $B$ is massive and ungraded in exposures along Solitario Canyon. A 30- to 60-cm-thick sequence of lithic-rich layers, commonly from 1 to $2 \mathrm{~mm}$ thick, defines crude stratification below ash layer 1 in some boreholes. This lithic-rich interval is locally overlain by a zone of coarse pumice clasts. Unit B ranges from 0.8 to $2.4 \mathrm{~m}$ thick in the Yucca Mountain region.

Ash layer 1 is composed of a basal, light-red to moderate orange-pink ash overlain by approximately $2 \mathrm{~cm}$ of well-sorted fallout (fig. $21 \mathrm{C}$ ). The clastsupported fallout is composed of white, vitric pumice clasts, crystals of feldspar, biotite, and pyroxene, and lithic clasts of grayish-red, pale red, or medium lightgray devitrified volcanic rock and subordinate black or brown glass. Pumice and lithic clasts vary from 1 to $4 \mathrm{~mm}$ in size. In borehole $\mathrm{G}-2$, ash layer 1 consists of two $1-\mathrm{cm}$-thick beds separated by about $3 \mathrm{~cm}$ of coarser, clast-supported fallout.

The contact between units $C$ and $B$ is gradational, typically over less than $30 \mathrm{~cm}$ but locally to $1 \mathrm{~m}$, and appears to mark an alteration boundary. The contact is marked by a color change from very pale orange above to light brown below.

\section{Unit A}

Unit A is a variably welded, moderately sorted, clast-supported, pumiceous fallout. A downward decrease in the content of phenocrysts and lithic clasts suggests that the unit may be compositionally zoned 
(see also Broxton and others, 1993). Progressive elongation (flattening) of pumice.clasts and loss of intergranular porosity accompanies an increased degree of welding downward.

Unit A generally lacks matrix material. Large pore spaces separate poorly sorted clasts in the upper part of the unit. Intergranular porosity decreases downward so that most porosity is eliminated in the lowest $15 \mathrm{~cm}$ of the deposit. Pumice clasts are vitric and medium light gray and moderate brown. They are nondeformed at the top of unit A, but become increasingly elongate downward (fig. 21D). Brown pumice clasts predominate light-gray clasts in the upper 50 to $100 \mathrm{~cm}$ of the deposit, but are subordinate to light-gray clasts in the middle and lower parts of the unit. At the top of the deposit, brown pumice clasts have phenocrysts of feldspar, minor biotite, and pyroxene, whereas light-gray clasts have sparse phenocrysts of feldspar. At lower stratigraphic levels, both types of pumice have only feldspar phenocrysts. Pumice clasts tend to coarsen upward from 7 to $12 \mathrm{~mm}$ near the base of the unit to 10 to $20 \mathrm{~mm}$ near the top. Phenocrysts decrease downward from 10 to 15 percent near the top of the deposit (predominantly feldspar with subordinate biotite, minor pyroxene, and lesser iron-titanium oxides) to 3 to 5 percent near the base of the unit (predominantly feldspar with minor biotite). Pyroxene is present only in the upper $0.5 \mathrm{~m}$ (approximately), where crystal content varies to 20 to 25 percent in some horizons. Lithic clasts decrease downward from 10 to 15 percent (locally 20 to 25 percent) near the top of unit $A$ to 5 to 7 percent (locally less) near the base of the unit. Lithic clasts are mostly devitrified, feldspar- and biotitebearing volcanic rocks in shades of medium light gray, grayish red, and moderate to pale red. Clasts of colorless glass are very rare; black and brown glassy lithics are minor to absent. Opal (?) locally forms a thin coating on fragments within the upper part of the deposit that imparts a pale red color to pumice, lithic clasts, and crystals. In exposures along Solitario Canyon (for example, measured section PTn\#6), unit A locally is strongly altered and occurs in shades of dusky red to medium red.

Unit A, which varies from massive to crudely stratified in exposures along Solitario Canyon, generally lacks sedimentary structures. The unit ranges from 1.6 to $2.8 \mathrm{~m}$ thick in the Yucca Mountain region; the moderately welded portion of unit A forms the basal 0 to $1.8 \mathrm{~m}$ of the unit.
The contact between units $\mathrm{A}$ and $\mathrm{B}$ is gradational, typically over less than $50 \mathrm{~cm}$, and is distinguished by less than 10 percent light-gray pumice clasts above the contact and greater than 10 percent pumice clasts below the contact. The contact between the non- to partially welded and moderately welded subunits is defined by the visible flattening of pumice clasts and greater induration of the rock (the rock breaks across pumice clasts rather than along grain boundaries) below the contact.

Unit A overlies either densely or moderately welded pyroclastic-flow material. In both cases, the contact between fall and flow deposits is sharp (fig. 22). Most commonly, unit A overlies the crystal-rich vitrophyre subzone (Tptrv1) or crystal-rich nonlithophysal zone (Tptrn) of the Topopah Spring Tuff. In other locales, unit A overlies moderately welded, vaporphase altered pyroclastic-flow material that, in turn, lies atop densely welded Topopah Spring Tuff. In these cases, unit A is nonwelded or only slightly welded at the fall-flow contact.

\section{Unit Distribution, Thickness, and Correlation}

The stratigraphic interval from the base of the Pah Canyon Tuff to the top of the pyroclastic-flow deposits of the Topopah Spring Tuff comprises a sequence of pumice-fall deposits overlain by a zone of possibly reworked material. Increases in welding and alteration toward the base of the fall deposits, presumably caused by heat and fluids released from the underlying pyroclastic-flow deposits, suggest that they were deposited shortly after the Topopah Spring pyroclastic flows. Although the source of the fall material is unknown, the inferred temporal association with the ash-flow tuff implies a source within the Claim Canyon caldera similar to that of the Topopah Spring Tuff (Byers and others, 1976). A Claim Canyon caldera source is consistent with the coarse, poorly sorted character of the fall material. The source of unit $D$ also is unknown. The comparatively high ratio of biotite to pyroxene visually estimated in samples of unit $D$ is consistent with petrographic analyses of pre-Pah Canyon Tuff lavas extruded near the margin of the Claim Canyon caldera (Byers and others, 1976). Unit D may be composed of pyroclastic or epiclastic material associated with these lavas. 


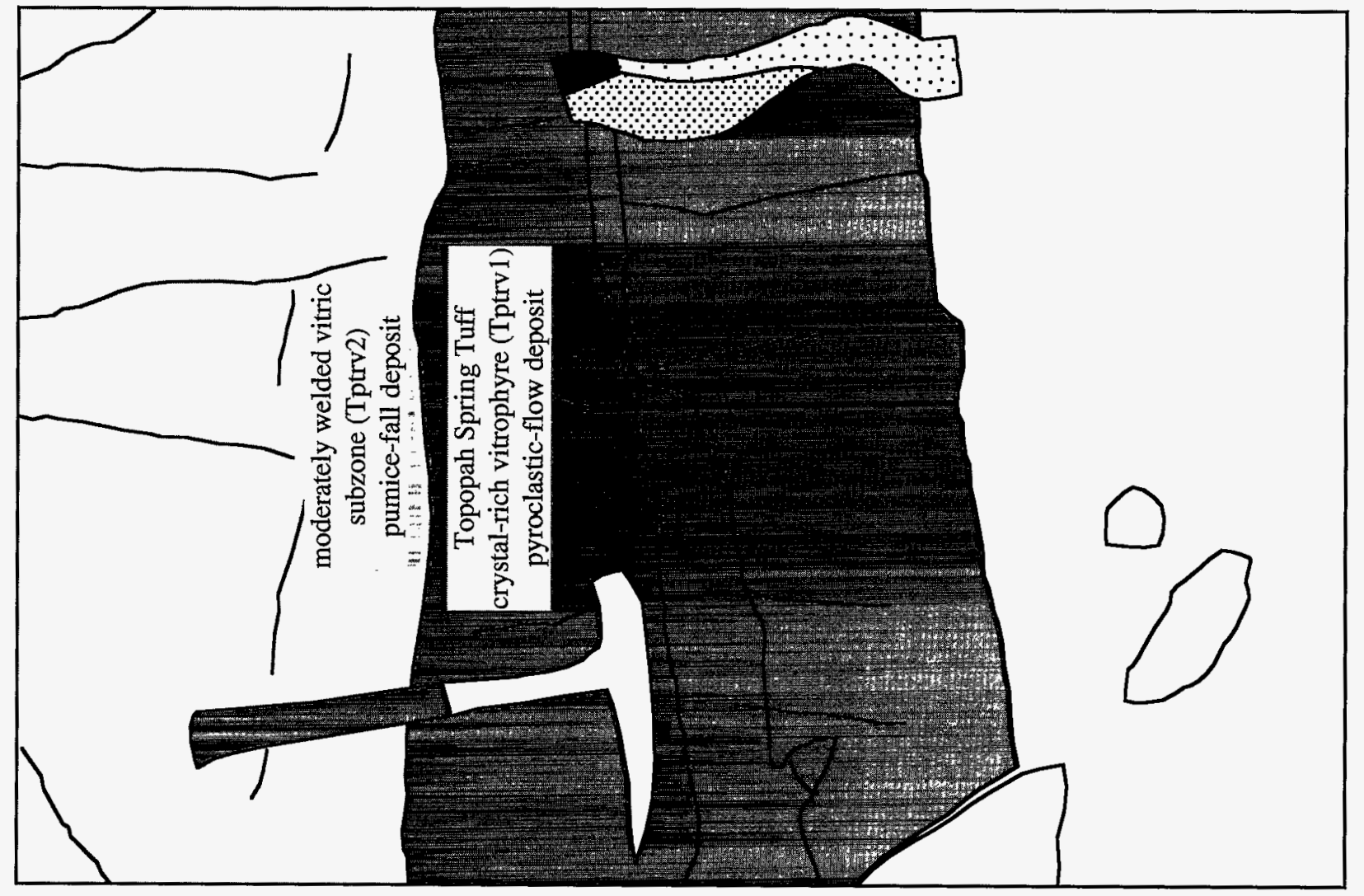

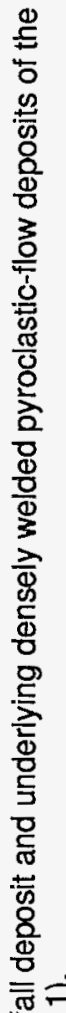

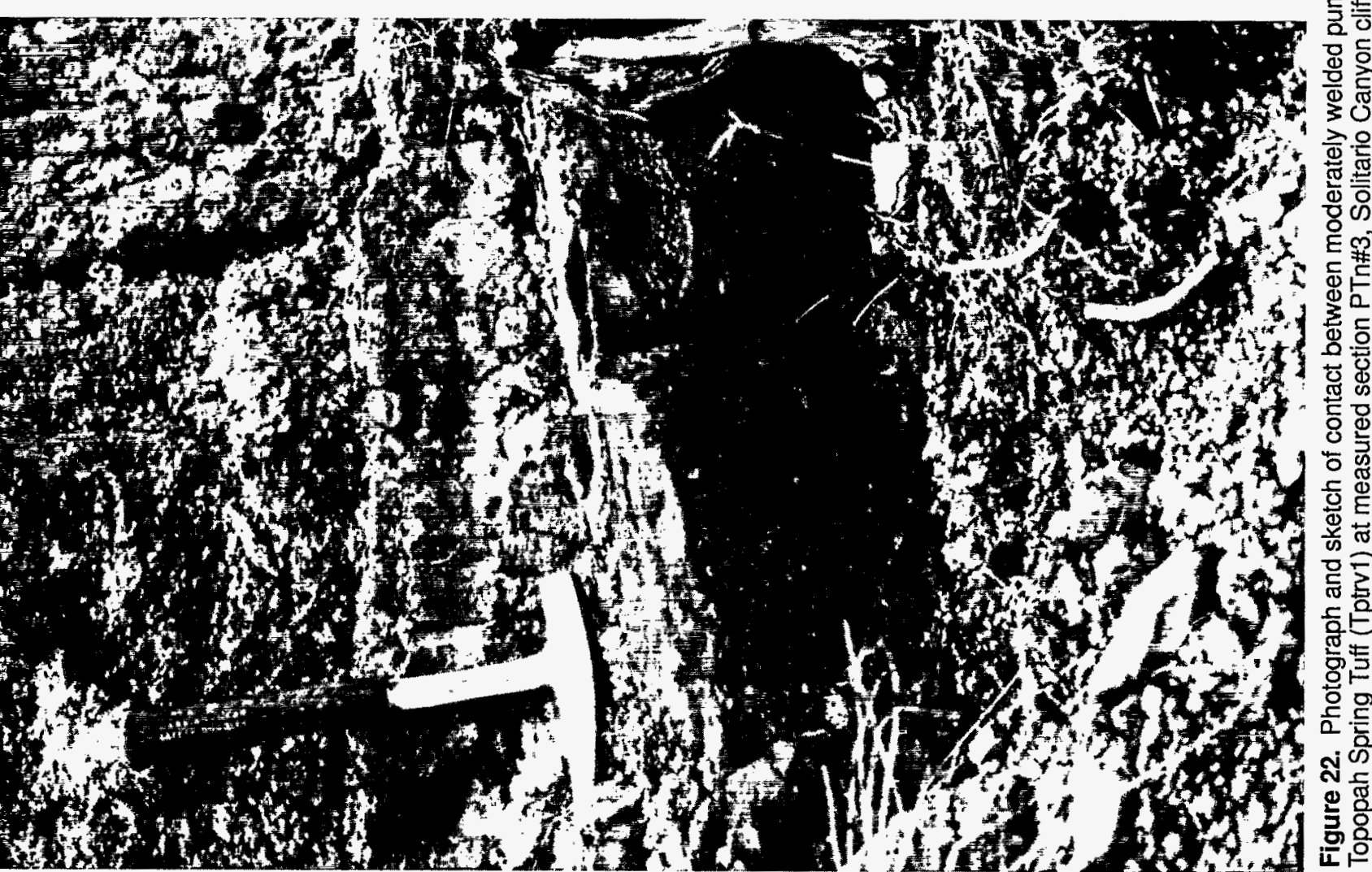

52 Stratigraphic Relations and Hydrologic Properties of the Paintbrush Tuff Nonwelded (PTn) Hydrologic Unit, Yucca Mountain, Nevada 
Figure 23 shows the apparent thickness of the interval (all units) from the base of the Pah Canyon Tuff to the top of the pyroclastic-flow deposits of the Topopah Spring Tuff. The thicknesses of the composite interval, aggregate pumice-fall deposits (units $A$ through $C$ ), and unit $D$ are remarkably consistent across the study area (also see the isochore map of this interval in Buesch, Nelson, and others, in press). The interval is thinner than expected in boreholes a\#1, NRG \#4, and UZ-N55, but slickensides occur on fracture surfaces recovered in core from a\#1 and NRG \#4, suggesting structural thinning within this interval. The only apparent thickness deviation occurs at measured section PTn\#5, where unit D is a coarse, immature, cross-laminated sandstone, and the underlying fall deposits are unusually thin.

The interval from the base of the Pah Canyon Tuff to the top of the pyroclastic-flow deposits of the Topopah Spring Tuff contains two stratigraphic marker horizons (ash layers 1 and 2) and a possibly reworked zone (unit D) that can be correlated through boreholes and exposures (figs. 5 and 6). The contacts between the three pumice-fall units (units A to C) cannot be correlated with confidence because they are gradational and are thought to define alteration zones within the fall material.

\section{Features of Welding, Secondary Crystallization, and Alteration}

Unit A grades upward from moderately welded to nonwelded as determined from changes in macroscopic porosity and pumice-clast deformation. In most boreholes and exposures, the transition from moderately welded material to non- to partially welded material occurs in the basal meter of the unit, but it locally extends to $2 \mathrm{~m}$ above the contact. The fallout is significantly deformed (perhaps densely welded) in the few centimeters immediately above the crystal-rich vitrophyre of the Topopah Spring Tuff. Unit A is significantly less welded where it overlies moderately welded, vapor-phase altered pyroclasticflow material; in such cases, it commonly is nonwelded throughout.

The deposits in this interval of the PTn unit are generally unaffected by secondary crystallization. Exceptions are noted in scattered exposures along the eastern side of Solitario Canyon, where pumice clasts are corroded and replaced by vapor-phase minerals in the lower few meters of unit A (measured sections PTn\#6 and \#8; fig. 1).

The PTn interval from the base of the Pah Canyon Tuff to the top of the crystal-rich vitrophyre of the Topopah Spring Tuff contains two intervals of alteration. Argillic alteration in the upper zone, which occurs in the top few centimeters to meter of unit $\mathrm{C}$, has an intensity that varies from weak to strong. Where present, altered unit $\mathrm{C}$ has variable, but distinctive, colors that include moderate red to pink, moderate to grayish orange-pink, and white. This alteration zone, informally referred to as the "red clay layer," was characterized qualitatively in cored boreholes (appendix 1). This argillic alteration is notably abrupt in its distribution; for example, the red clay layer is strongly developed in borehole UZ-N32 but is weakly developed in borehole UZ-N31 that is located only $23 \mathrm{~m}$ away. The variability of the red clay layer suggests that it may represent fumarolic or shallow hydrothermal alteration related to cooling of the underlying pyroclastic-flow deposits of the Topopah Spring Tuff (refer to Sheridan, 1970). The lower alteration zone occurs within unit $B$ and imparts the distinctive light-brown coloration to the unit. The character of this diffuse alteration is unknown; however, the color and macroscopic texture of the rock suggests that it formed through partial oxidation and argillization of vitric pumice clasts. Exposures along the east side of Solitario Canyon locally contain abrupt and irregular discontinuities in the color change that defines the contact between units $B$ and $C$ and in the degree of alteration of unit $\mathrm{A}$. These observations indicate that the alteration processes that accompanied cooling of the underlying pyroclastic-flow deposits are complex.

Silicified horizons occur locally in exposures of units A and B along the eastern side of Solitario Canyon (measured sections PTn\#6, \#8, and \#11; fig. 1). These zones are typically associated with comparatively intense alteration of the enclosing rocks that is manifested by obliterated pumice-clast margins, oxidized biotite phenocrysts, and reddish matrix color. 


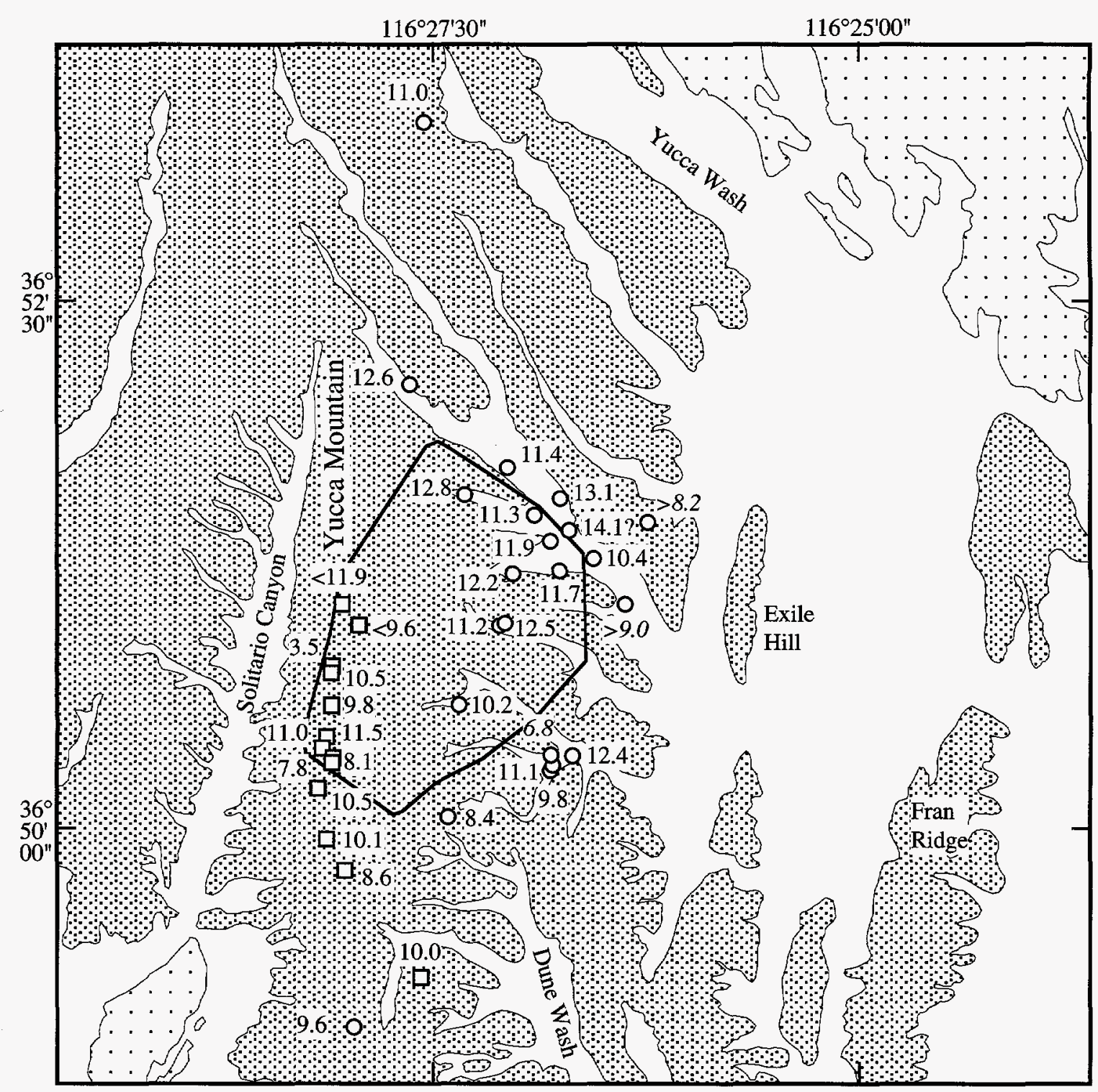

\section{EXPLANATION}
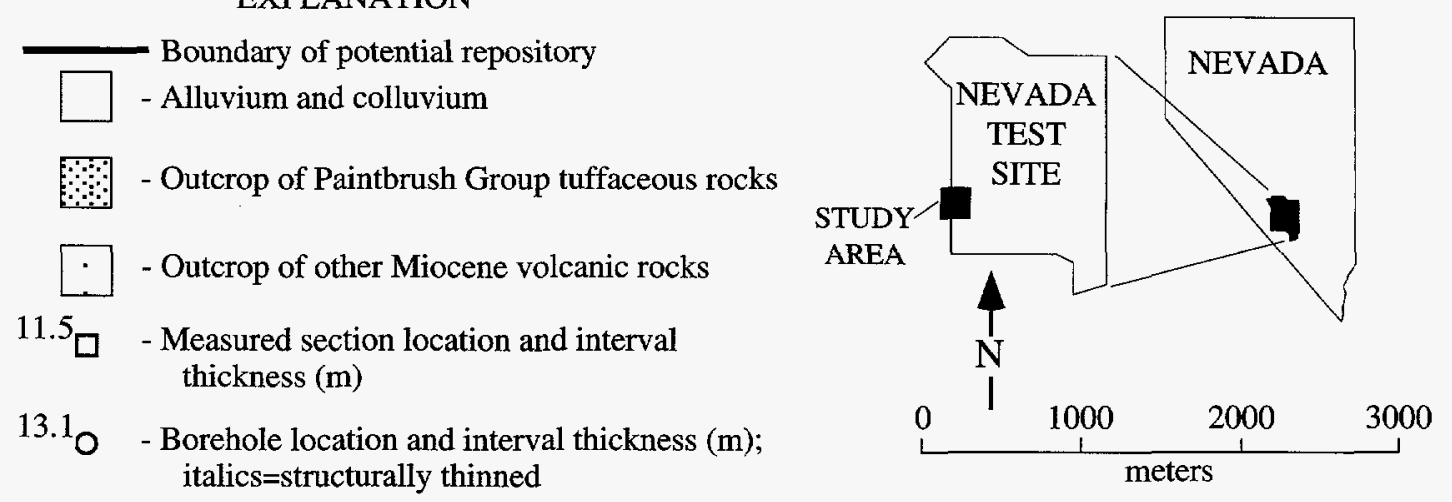

Figure 23. The apparent thickness of interval from the base of the Pah Canyon Tuff to the top of the welded pyroclastic-flow deposit of the Topopah Spring Tuff determined in cored boreholes and measured sections. Probable structural thinning is indicated by fractures with slickensided surfaces. Borehole and section locations are shown in figure 1. 


\section{HYDROLOGIC PROPERTIES OF THE PTn UNITS}

Appendix 4 lists the hydrologic properties determined for core samples collected from the PTn unit in boreholes drilled since 1991. In the following discussions, these data are supplemented, as necessary, with previously published analyses of outcrop samples (Istok and others, 1994; Flint and others, 1996; Rautman and others, 1995). Measured properties include bulk density, porosity, particle density, and percent saturation; published data additionally report measured and estimated saturated hydraulic conductivity. Results are reported for borehole samples processed at relative humidity $(\mathrm{RH})$ and at higher temperature $\left(105^{\circ} \mathrm{C}\right)$. Relative humidity determinations give a better approximation to the naturally occurring rock density and porosity because hydrous minerals (clay and zeolite) are not destroyed during analysis. Similarly, differences between the two sets of measurements give a first approximation of the influence of hydrous minerals on the hydrologic properties of a sample. Unless otherwise noted, all measurements shown on illustrations or discussed in the text were determined at relative humidity.

\section{Crystal-Poor Tiva Canyon Tuff (Tpcp)}

The base of the Tiva Canyon Tuff (Tpc) contains the first significant change in hydrologic properties below the present topographic surface of Yucca Mountain. The downward decrease in welding near the base of the pyroclastic-flow deposits is manifested by increasing porosity and decreasing bulk density. In contrast, the downward transition from devitrified to vitric tuff creates an abrupt decrease in particle density.

\section{General Hydrologic Properties}

\section{Crystal-Poor Lower Nonlithophysal Zone, Columnar Subzone (Tpcplnc) and Crystal-Poor Vitric Zone, Moderately Welded Subzone (Tpcpv2)}

The porosity and bulk density of borehole samples collected from the lower part of the Tiva Canyon Tuff are shown on figures 24 and 25 . In these figures, plot A shows the porosity and bulk density of samples collected in a 3-m interval above the contact between densely and moderately welded rock in the columnar subzone of the crystal-poor lower nonlithophysal zone (Tpcplnc). Figures 24B and 25B plot samples col- lected from the columnar subzone where it is moderately welded (contact depths are given in appendix 3, property data are given in appendix 4). Across the dense to moderate welding contact, mean porosity increases from 12.5 to 22.8 percent (fig. 24) and average bulk density decreases from 2.16 to $1.88 \mathrm{~g} / \mathrm{cm}^{3}$ (fig. 25). This contact is gradational; therefore, porosity and bulk density values for densely welded samples immediately above the contact differ from those higher in the section. Flint and others (1996) report average porosity of 6 to 9 percent and average bulk density of 2.25 to $2.34 \mathrm{~g} / \mathrm{cm}^{3}$ for samples collected from densely welded Tiva Canyon Tuff above the interval used here.

The average porosity and bulk density of the moderately welded columnar subzone are similar to the mean porosity ( 23.5 percent) and bulk density $\left(1.76 \mathrm{~g} / \mathrm{cm}^{3}\right)$ of the moderately welded vitric subzone (Tpcpv2, figs. 24C and 25C). The similarity in mean property values in these units allows them to be grouped during hydrologic modeling. In the hydrologic models discussed below, the moderately welded units are represented by a single model layer (SB3) that was assigned an average porosity of 20 percent (table 2).

The porosity and bulk density of moderately welded columnar and vitric samples (figs. 24 and 25, appendix 4) generally compare favorably with analyses of samples collected from outcrop (Istok and others, 1994; Rautman and others, 1995). Istok and others (1994) and Rautman and others (1995) divided the base of the Tiva Canyon Tuff into two units - an "upper ash-flow subunit" that is nonwelded at its base and densely welded at its top, and a "lower ash-flow subunit" that is nonwelded throughout. The "upper ash-flow subunit" is generally equivalent to the moderately welded rocks of the columnar and vitric subzones. Mean porosity and bulk density reported for samples collected from the "upper ash-flow subunit" are 19.5 percent and $1.89 \mathrm{~g} / \mathrm{cm}^{3}$, respectively (Istok and others, 1994; Rautman and others, 1995).

Although porosity and bulk density of moderately welded vitric and devitrified samples are similar, particle density changes abruptly across the contact (fig. 26). The difference in particle density values reflects the transformation of glass to crystalline material. Hydrologic model layer SB3 (table 2) is given a particle density of $2.42 \mathrm{~g} / \mathrm{cm}^{3}$, a value intermediate to those determined for devitrified $\left(2.5 \mathrm{~g} / \mathrm{cm}^{3}\right)$ and vitric $\left(2.3\right.$ and $\left.2.4 \mathrm{~g} / \mathrm{cm}^{3}\right)$ samples. 

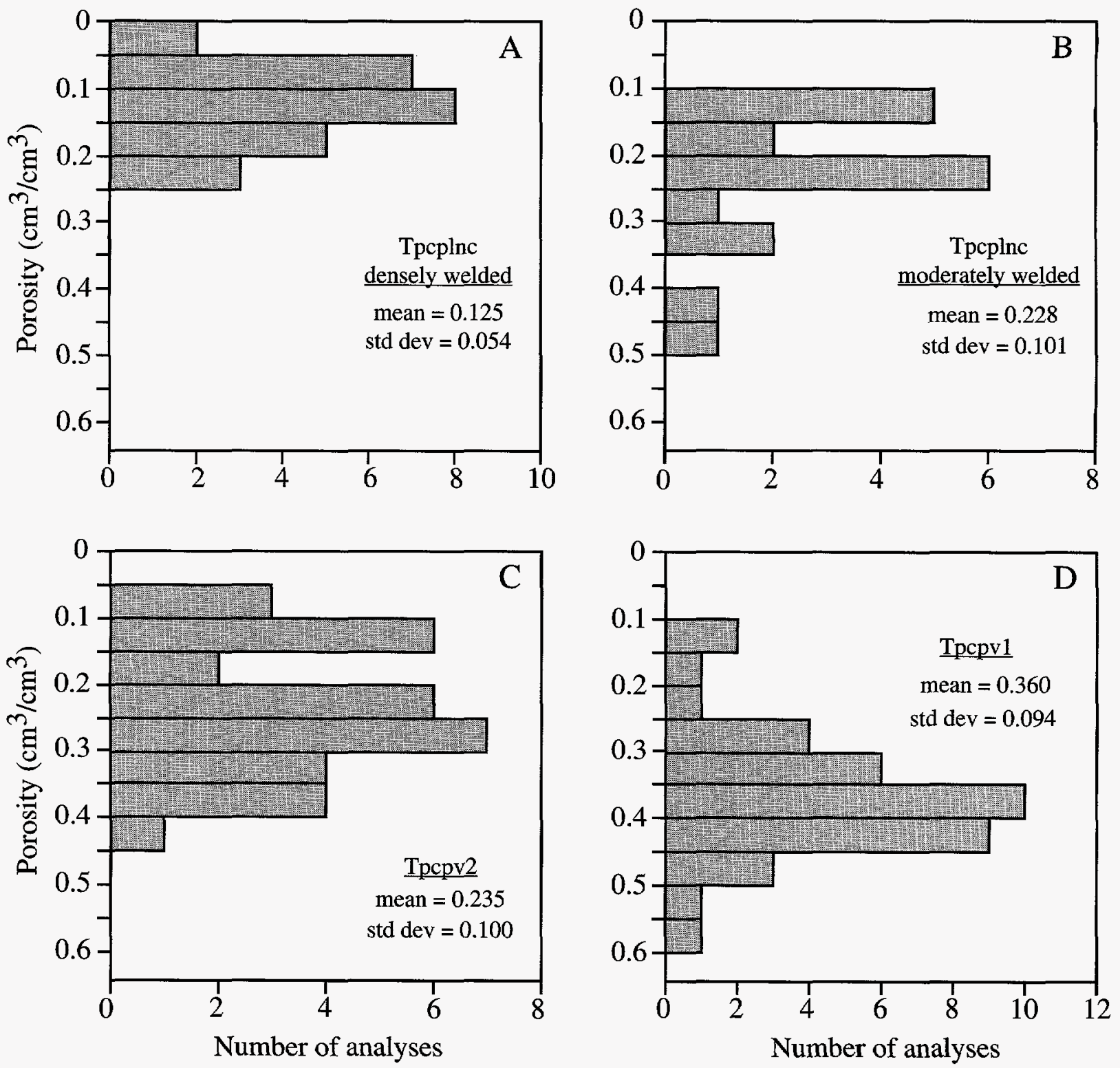

Figure 24. Porosity histograms for units in the lower Tiva Canyon Tuff. Porosity was determined at relative humidity (appendix 4).

\section{Crystal-Poor Vitric Zone, Non- to Partially Welded Subzone (Tpcpv1)}

The mean porosity and bulk density of samples collected from the non- to partially welded crystalpoor vitric subzone (Tpcpv1) are 36 percent and

$1.44 \mathrm{~g} / \mathrm{cm}^{3}$, respectively (figs. $24 \mathrm{D}$ and $25 \mathrm{D}$ ). These values are significantly different from the overlying moderately welded vitric subzone, but are similar to those of the underlying nonwelded pre-Tiva Canyon Tuff bedded tuffs (see discussion below). In the hydrologic models discussed below, the non- to partially welded vitric material is represented by model layer SB1, which was assigned a porosity of 40 percent (table 2 ). The porosity and bulk density values of non- to partially welded samples (figs. 24D and 25D; appendix 4) are generally equivalent to values determined for samples collected from outcrop (Istok and others, 1994; Rautman and others, 1995). The average porosity and bulk density reported for the nonwelded "lower ash-flow subunit" are 40 percent and $1.38 \mathrm{~g} / \mathrm{cm}^{3}$, respectively (Istok and others, 1994; Rautman and others, 1995). 

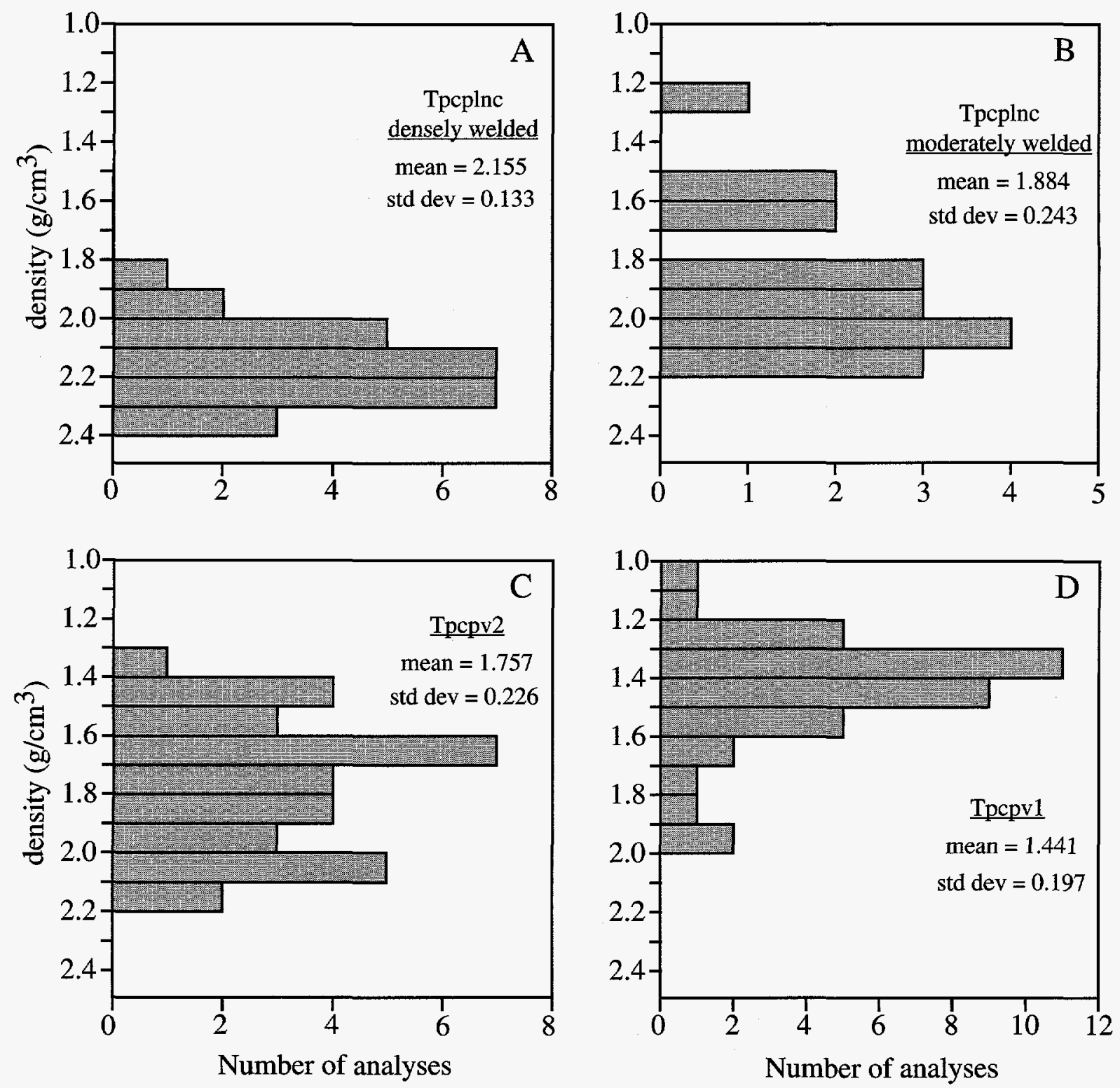

Figure 25. Bulk density histograms for units in the lower Tiva Canyon Tuff. Bulk density was determined at relative humidity (appendix 4).

\section{Stratigraphic Controls on Hydrologic Properties}

Porosity, bulk density, and particle density data for the lower part of the Tiva Canyon Tuff show predictable downward changes that reflect the decrease in welding (Istok and others, 1994; Rautman and others, 1995). However, the degree of saturation does not follow a predictable trend in this interval. In particular, an abrupt increase in saturation (values typically approach 100 percent) occurs in the upper part of the moderately welded vitric subzone and in lower part of moderately welded columnar subzone (fig. 27). This increased saturation has been observed in all boreholes examined in the study area (appendix 4).
The zone of high saturation in the moderately welded rocks correlates with a zone in which the difference in porosity determined at relative humidity and at high temperature is greater than in the surrounding strata (fig. 27). This difference is attributed to the presence of abundant hydrous minerals such as clays (for example, Bush and Jenkins, 1970) and generally occurs at the same stratigraphic position as the zone of argillic alteration observed in core. Presumably, argillic alteration reduces permeability and inhibits the downward flow of water, producing elevated levels of saturation. 


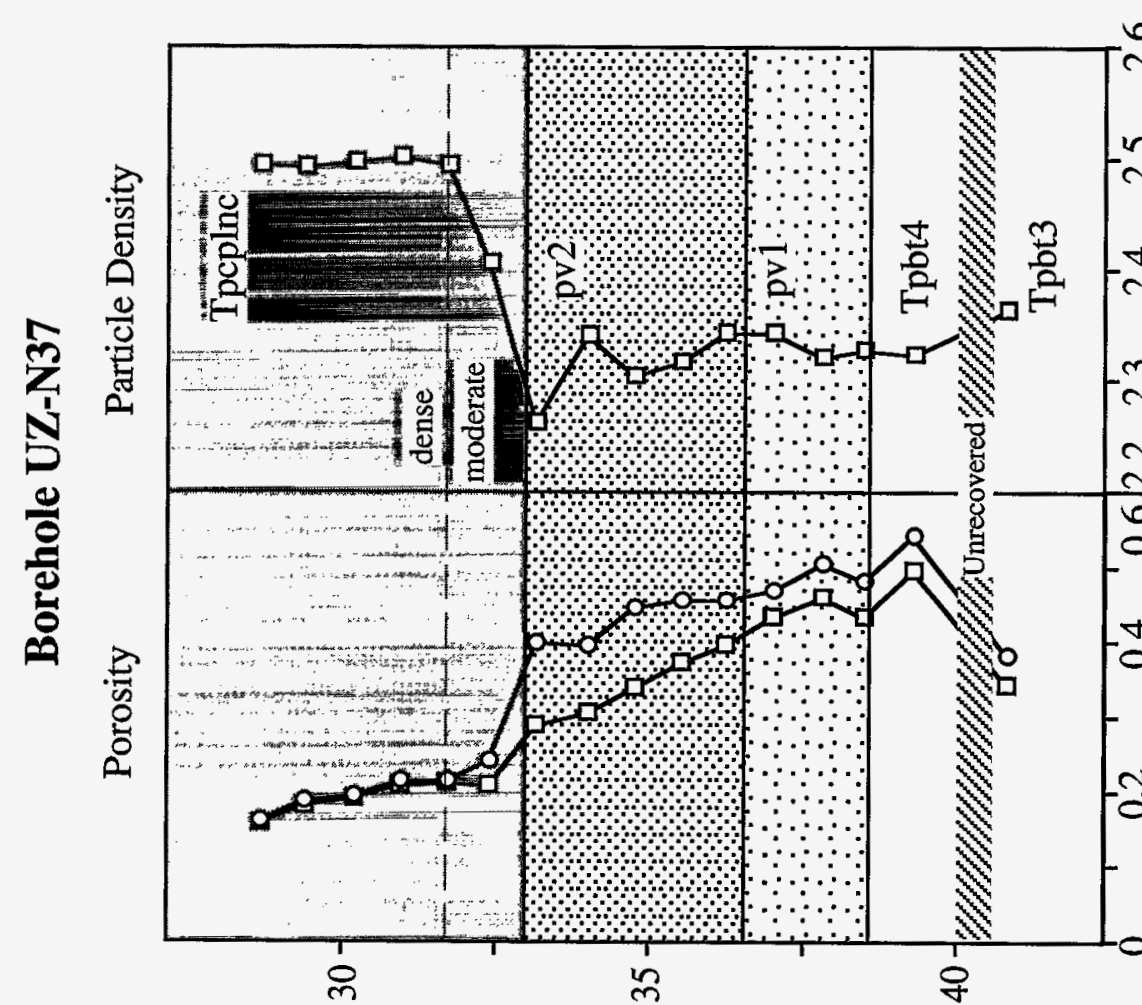

(ui) प1dəव

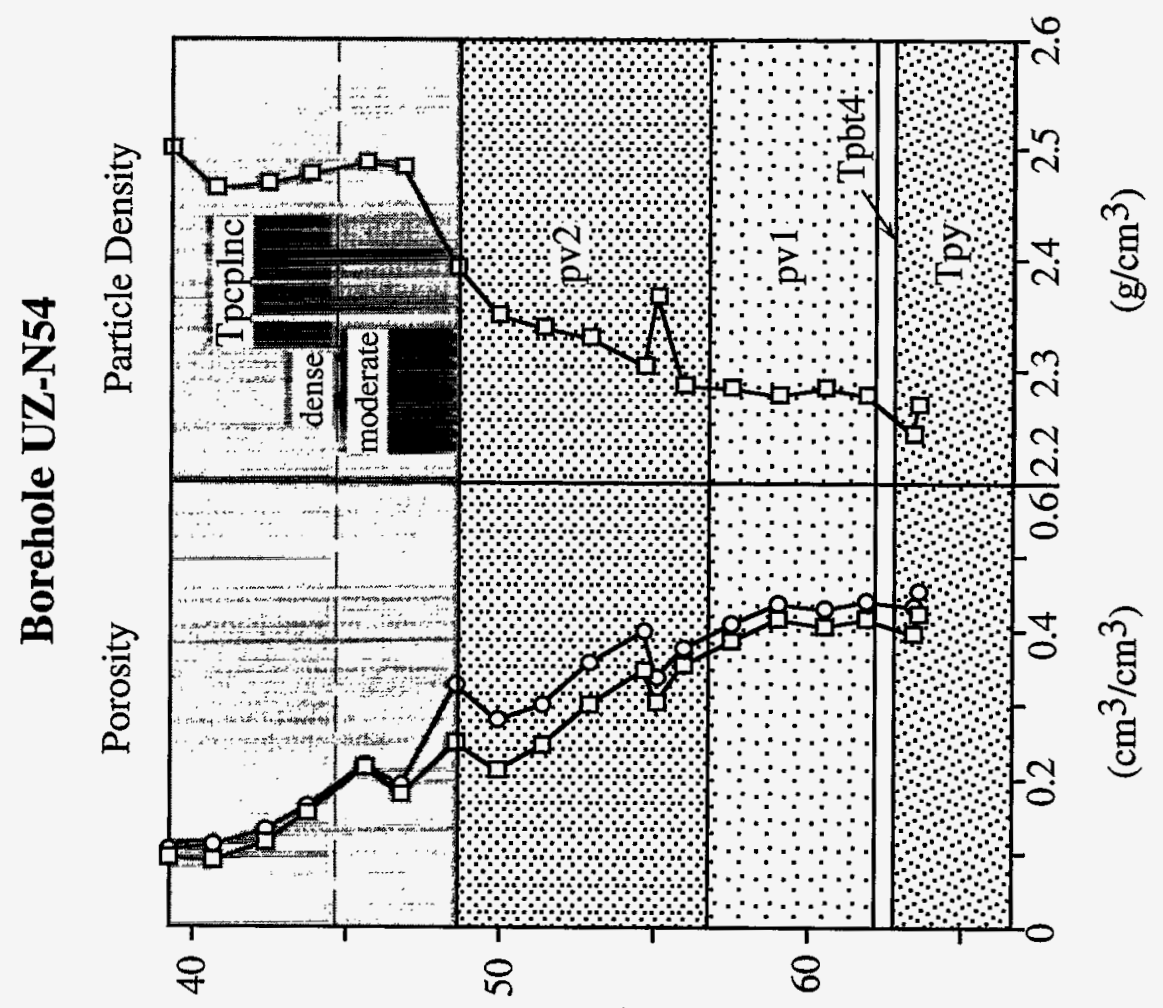

(๘I) प1 dəव

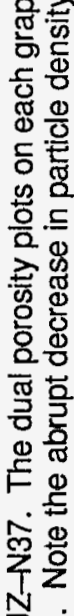

둥

范实

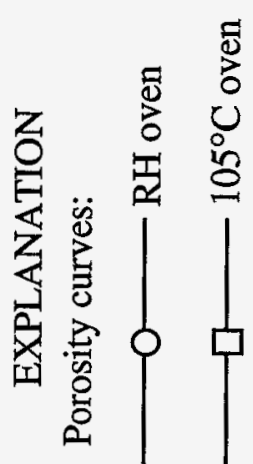

응.은

今分紊

象

잉.

$8 \%$

든ㅎㅇㅇ

砉

동든

옹옹

芯壱

蛋

늘유

\$

흐홍

몽을

产要昰

视完

층

$\Phi$

을 동

范要

은

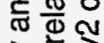

謨

은

8.

을혀응

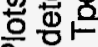

욤

过

한흔 恶 


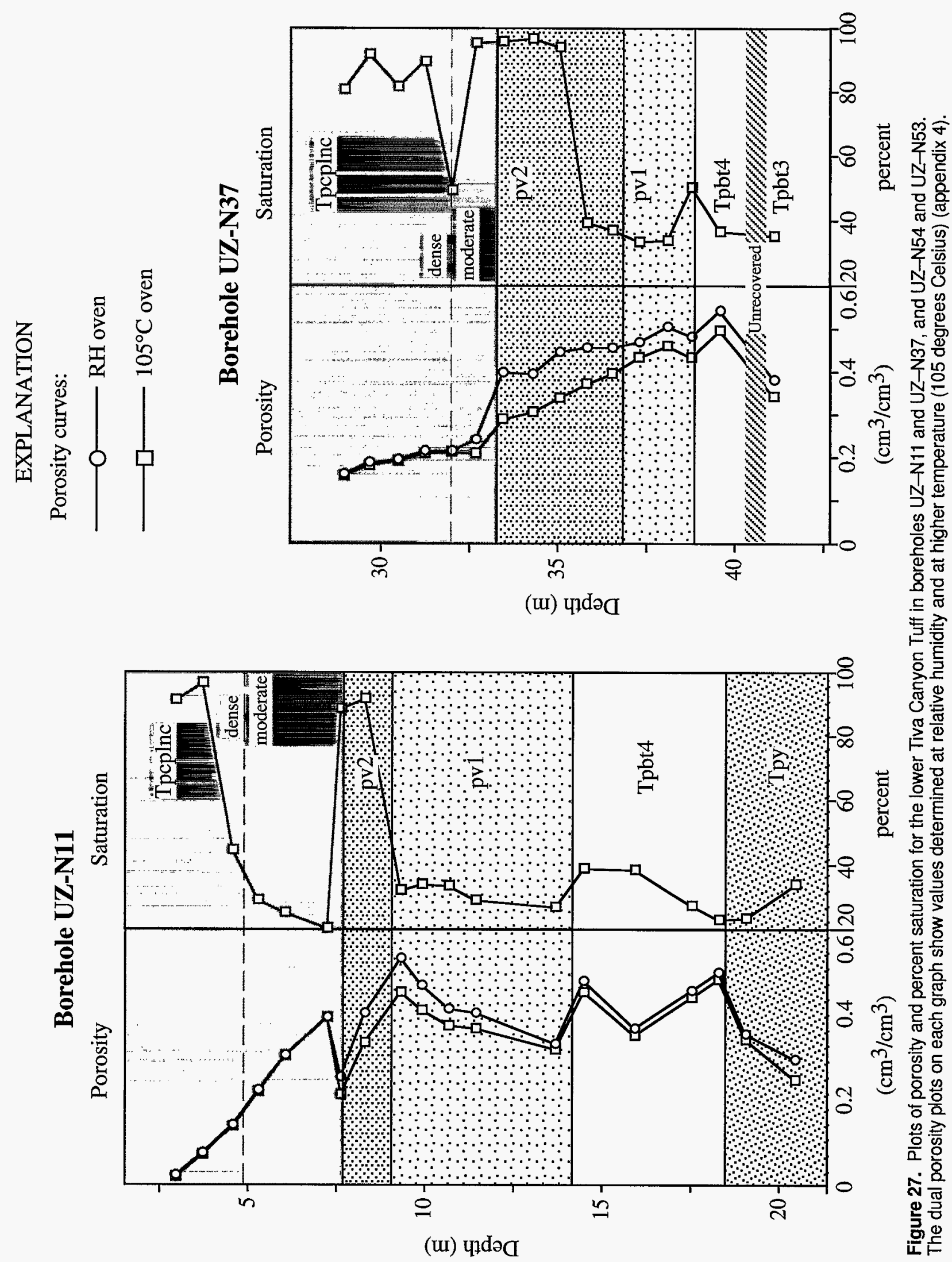




\section{Borehole UZ-N53}
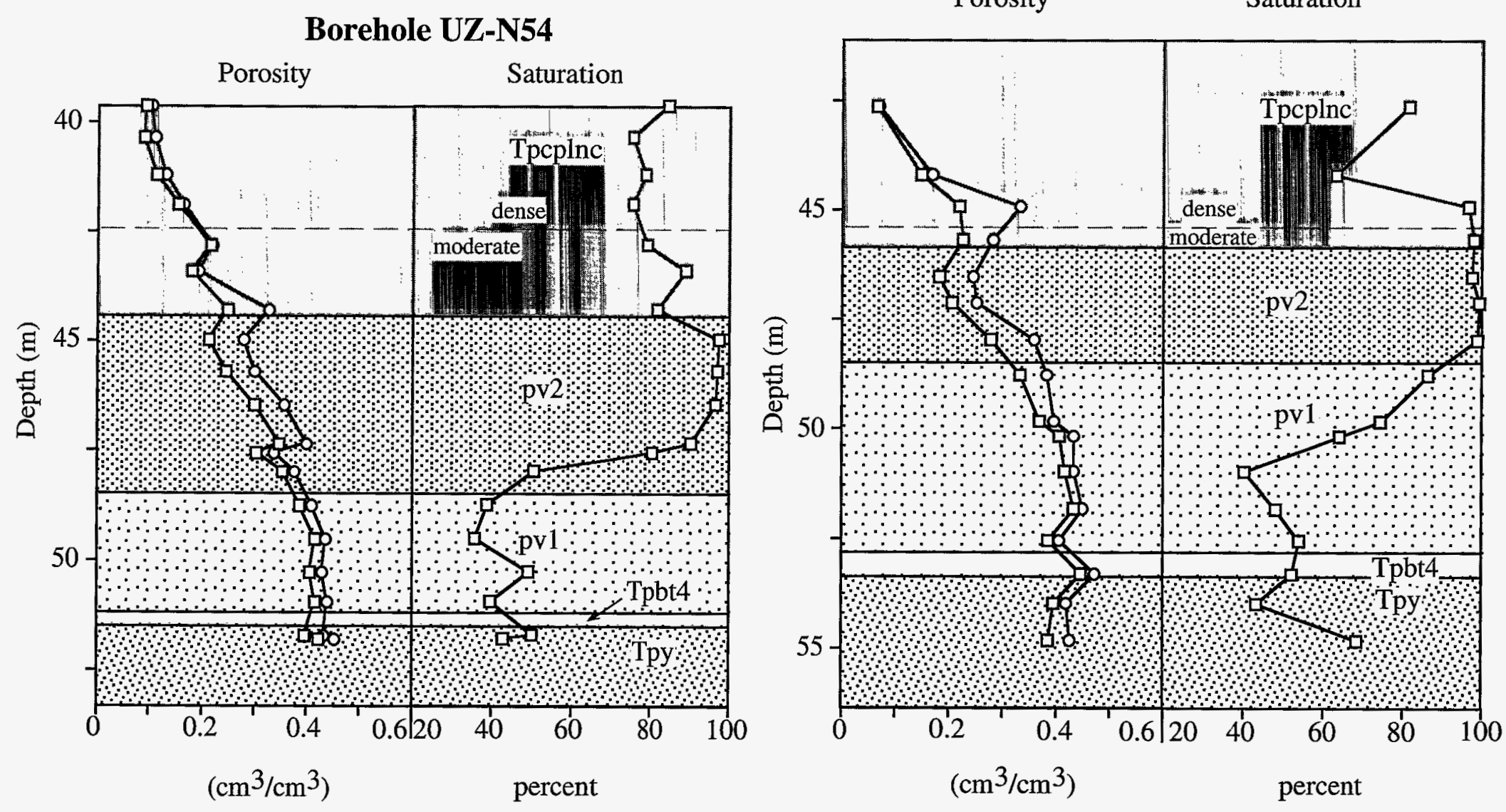

\section{EXPLANATION}

Porosity curves:

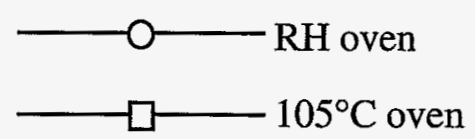

Figure 27. Plots of porosity and percent saturation for the lower Tiva Canyon Tuff in boreholes UZ-N11 and UZ-N37, and UZ-N54 and UZ-N53. The dual porosity plots on each graph show values determined at relative humidity and at higher temperature (105 degrees Celsius) (appendix 4)-Continued. 
The zone of argillization also appears to affect the saturated hydraulic conductivity of these samples. Figure 28 shows porosity and saturated hydraulic conductivity plotted relative to depth for the entire PTn unit in borehole UZ \#16 and for outcrops located along the east side of Solitario Canyon (Flint and others, 1996). Samples from the moderately welded vitric and columnar subzones have saturated hydraulic conductivities of approximately $10^{-8}$ to $10^{-11} \mathrm{~m} / \mathrm{sec}$ (fig. 28; Flint and others, 1996; L.E. Flint, unpub. data, 1995). These values are an order of magnitude or more lower than those of the underlying nonwelded vitric tuff, and they are several orders of magnitude lower than the most conductive strata of the PTn unit (fig. 28).

\section{Pre-Tiva Canyon Tuff Bedded Tuffs (Tpbt4)}

Unit A of the pre-Tiva Canyon Tuff bedded tuffs is thin and laterally discontinuous (appendix 3); therefore, lithologic units A and B are grouped in the following discussion. Hydrologic properties were determined for samples collected from eight boreholes drilled since 1991 (appendix 4).

\section{General Hydrologic Properties}

The porosity and bulk density of pre-Tiva Canyon Tuff bedded tuff samples are plotted in figure 29 . These data are relatively consistent, with the exception of four samples collected from borehole UZ-N31 that are more dense and less porous than other samples (fig. 29). Borehole UZ-N31 is located in the bottom of Split Wash, and the Tpbt4 samples from this borehole have comparatively high levels of saturation and a relatively large difference in porosity values determined at relative humidity and at higher temperature (appendix 4). This suggests that the UZ-N31 samples may be argillically altered and could have lower porosity and higher bulk density as a result.

The average porosity and bulk density of the pre-Tiva Canyon Tuff bedded tuff samples is 39.5 percent and $1.39 \mathrm{~g} / \mathrm{cm}^{3}$, respectively (fig. 29). If the four anomalous samples from borehole UZ-N31 are ignored, the average porosity of Tpbt 4 increases to 47.2 percent and the average bulk density decreases to $1.20 \mathrm{~g} / \mathrm{cm}^{3}$. In the hydrologic models discussed below, the pre-Tiva Canyon Tuff bedded tuffs are represented by model layer BT4, which was assigned a porosity of 0.44 percent (table 2 ).
The porosity and bulk density of borehole samples of the pre-Tiva Canyon Tuff bedded tuffs (fig. 29) are slightly different than for samples collected from outcrop (Istok and others, 1994; Rautman and others, 1995). Istok and others (1994) and Rautman and others (1995) report an average porosity of 52.0 percent and an average bulk density of $1.13 \mathrm{~g} / \mathrm{cm}^{3}$ for the "basal pumice bed subunit," which is equivalent to unit B of Tpbt4.

\section{Yucca Mountain Tuff (Tpy)}

Hydrologic properties were measured for samples collected from nine boreholes drilled since 1991 that contain whole or partial intervals of the Yucca Mountain Tuff (appendix 4). These boreholes capture complete sections of nonwelded and non- to partially welded, vitric Yucca Mountain Tuff and partial sections of Yucca Mountain Tuff that vary from nonwelded and vitric to welded and devitrified. Although the cored intervals traverse both the upper and lower vitric-devitrified transitions, hydrologic-property data for complete stratigraphic sequences through welded Yucca Mountain Tuff are not available from borehole samples. However, hydrologic properties were reported for surface samples collected through the sequence of welded Yucca Mountain Tuff south of Yucca Wash near Prow Pass (Flint and others, 1996).

\section{General Hydrologic Properties}

Compiled hydrologic properties for the Yucca Mountain Tuff recovered in boreholes are shown in figure 30. Histograms of Yucca Mountain Tuff analyses illustrate that the bulk density of vitric samples typically varies from 1.2 to $1.6 \mathrm{~g} / \mathrm{cm}^{3}$ and that pore space commonly composes 25 to 45 percent of the tuff. Samples of devitrified Yucca Mountain Tuff, recovered from the interior, more densely welded portion of the sheet, have significantly higher density ( 1.7 to $2.2 \mathrm{~g} / \mathrm{cm}^{3)}$ and lower porosity (less than 30 percent). Samples of welded and devitrified Yucca Mountain Tuff from the Yucca Wash traverse are similar and attain maximum densities of $2.34 \mathrm{~g} / \mathrm{cm}^{3}$ and minimum porosities of 5 to 6 percent (Flint and others, 1996). As expected, the vitric and devitrified samples have distinctly different particle densities (fig. 31). 


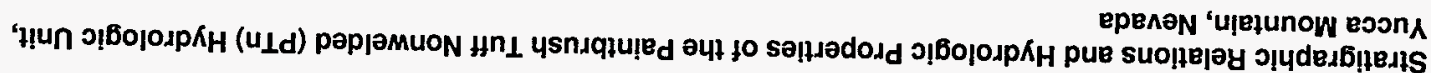

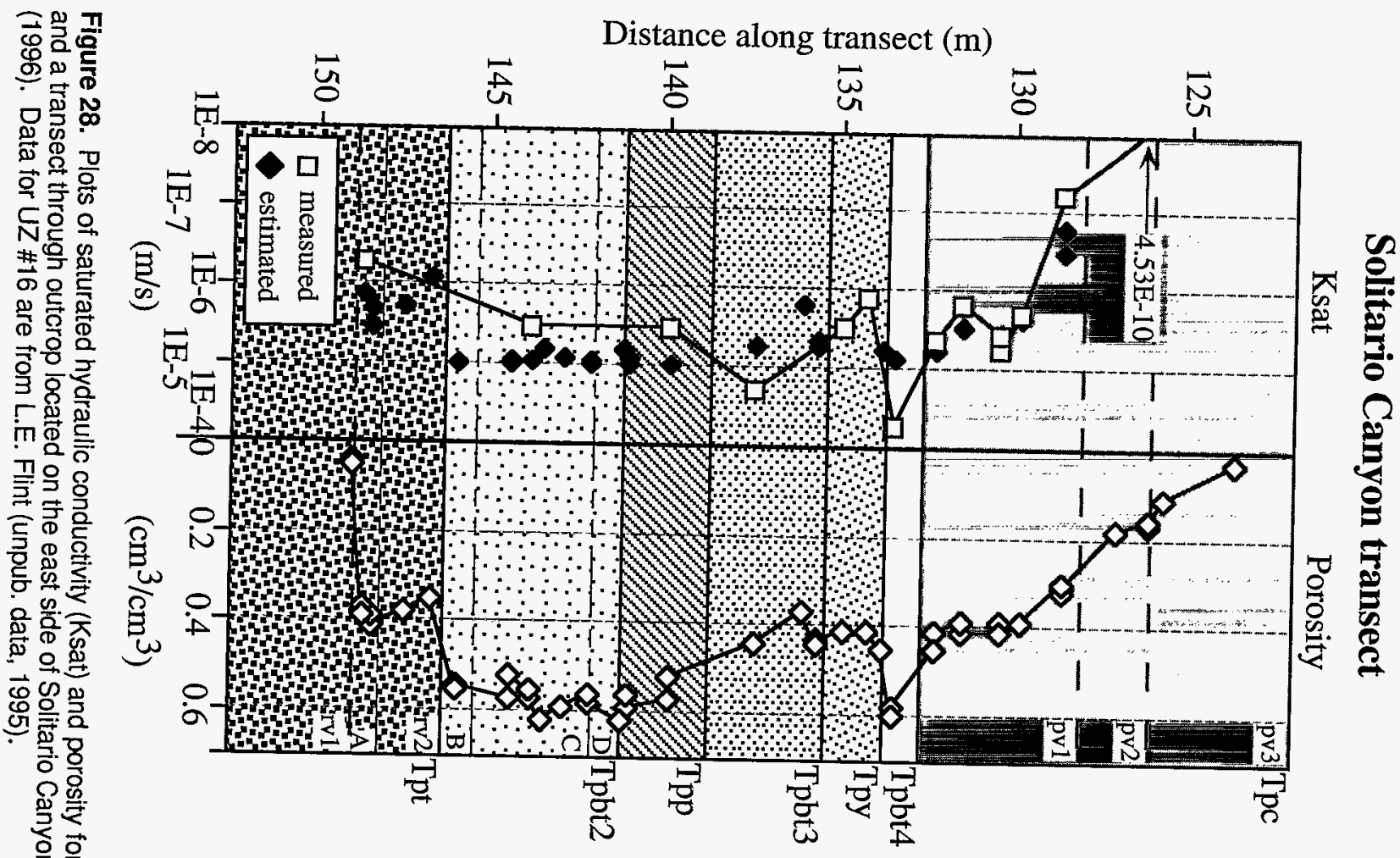

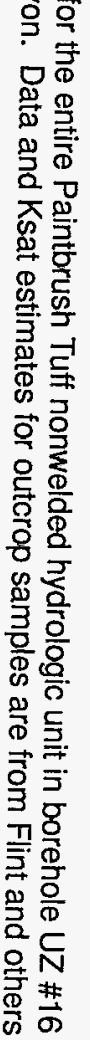

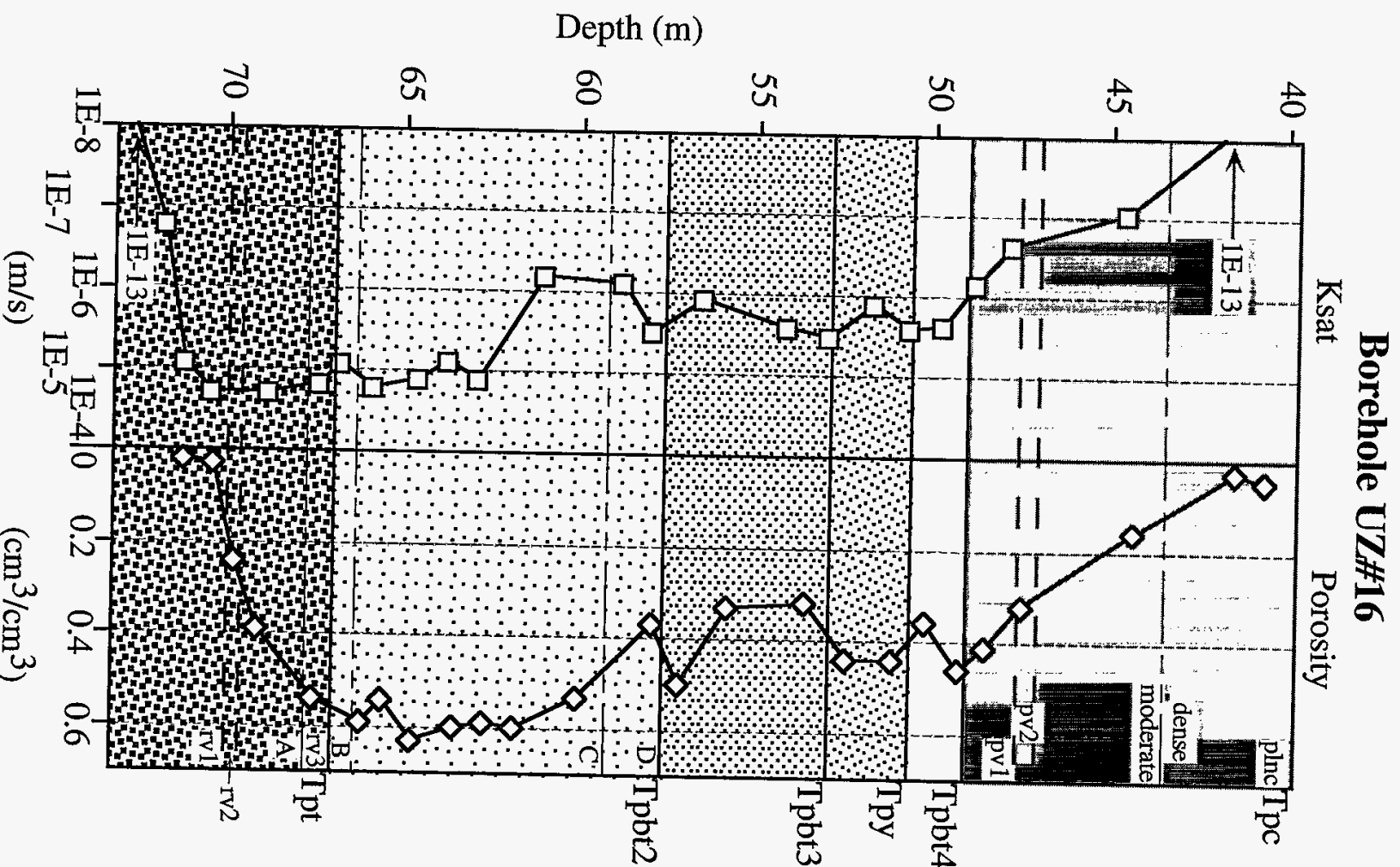



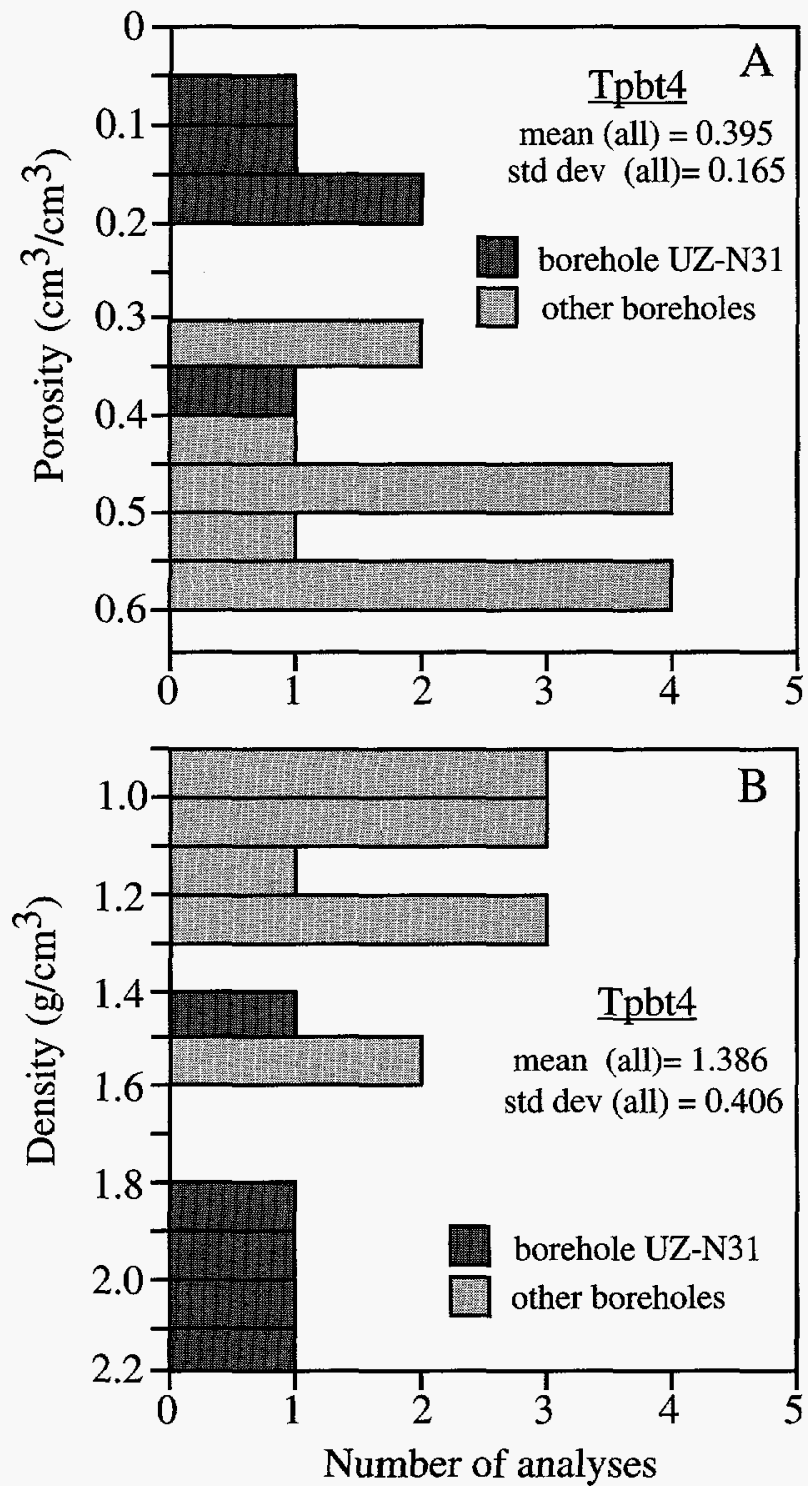

Figure 29. Porosity (A) and bulk density (B) histograms for the pre-Tiva Canyon Tuff bedded tuffs (Tpbt4).

Porosity and bulk density determined at relative humidity (appendix 4).

\section{Stratigraphic Controls on Hydrologic Properties}

The welding, crystallization, and alteration history of the Yucca Mountain Tuff produces locally significant vertical variations in hydrologic properties. Figures 32 and 33 illustrate that differences in measured hydrologic properties can be related to the macroscopic lithologic variations outlined in the section on welding and crystallization features. Figure 32 plots bulk density and porosity relative to depth beneath the top of the Yucca Mountain Tuff. The upper contact locally is disturbed by post-depositional processes; however, samples of undisturbed material from the upper 1 to $2 \mathrm{~m}$ of the deposit have bulk densities of 1.25 to $1.28 \mathrm{~g} / \mathrm{cm}^{3}$ and porosities of 40 to 44 percent (fig. 32; appendix 4). These values contrast slightly with samples from the lower 1 to $2 \mathrm{~m}$, where bulk densities are typically 1.40 to $1.42 \mathrm{~g} / \mathrm{cm}^{3}$ and porosity varies from 28 to 36 percent. Figure 32 also illustrates that the tuff has restricted ranges of density and porosity at the point where subspherical bubble-wall shards begin to deform to ellipsoidal shapes ( 1.37 to $1.40 \mathrm{~g} / \mathrm{cm}^{3}$ and 36 to 38 percent, respectively; see also appendix 4 , borehole UZ-N11). The change from deformed to nondeformed bubble-wall shards observed in the lower part of the deposit in two boreholes corresponds to bulk densities of 1.42 to $1.45 \mathrm{~g} / \mathrm{cm}^{3}$ and porosities of 30 to 34 percent (figs. 32 and 33).

A sharp change in the density and porosity of the Yucca Mountain Tuff occurs below the vitricdevitrified contact and within the silicified zone of borehole UZ-N33 (fig. 32); a similar, but less impressive, feature is observed in borehole UZ-N11. This abrupt change in hydrologic properties is not present where the entire deposit is vitric and less welded (borehole SD-9). As shown in figure 34, the percent saturation doubles directly above the silicified interval in borehole UZ-N33 despite a porosity decrease of only 25 percent. This sharp increase suggests that matrix silicification, formed perhaps during the welding process, can produce important hydrologic effects. Significantly, boreholes UZ-N33 and SD-9, in which the Yucca Mountain Tuff has greatly different hydrologic properties, are separated by only $570 \mathrm{~m}$ (fig. 1), indicating that the southward change in hydrologic character is abrupt.

The presence of alteration within the Yucca Mountain Tuff can be indirectly detected by contrasting porosity determined at relative humidity with porosity determined at high temperature. Argillic alteration is macroscopically prominent for 1 to $2 \mathrm{~m}$ immediately below devitrified-vitric boundary in borehole UZ-14 (see the section on welding, crystallization, and alteration of the Yucca Mountain Tuff). As shown on figure 35, this interval coincides with an abrupt departure in measured porosities, within which porosity measured at high temperature is up to 73 percent greater than porosity determined at relative humidity. This interval also has extremely high saturation, locally in excess of 100 percent, that may reflect water bound in hydrous minerals. In contrast, unaltered, vitric parts of the Yucca Mountain Tuff do not show a great difference in measured porosities (fig. 34). 

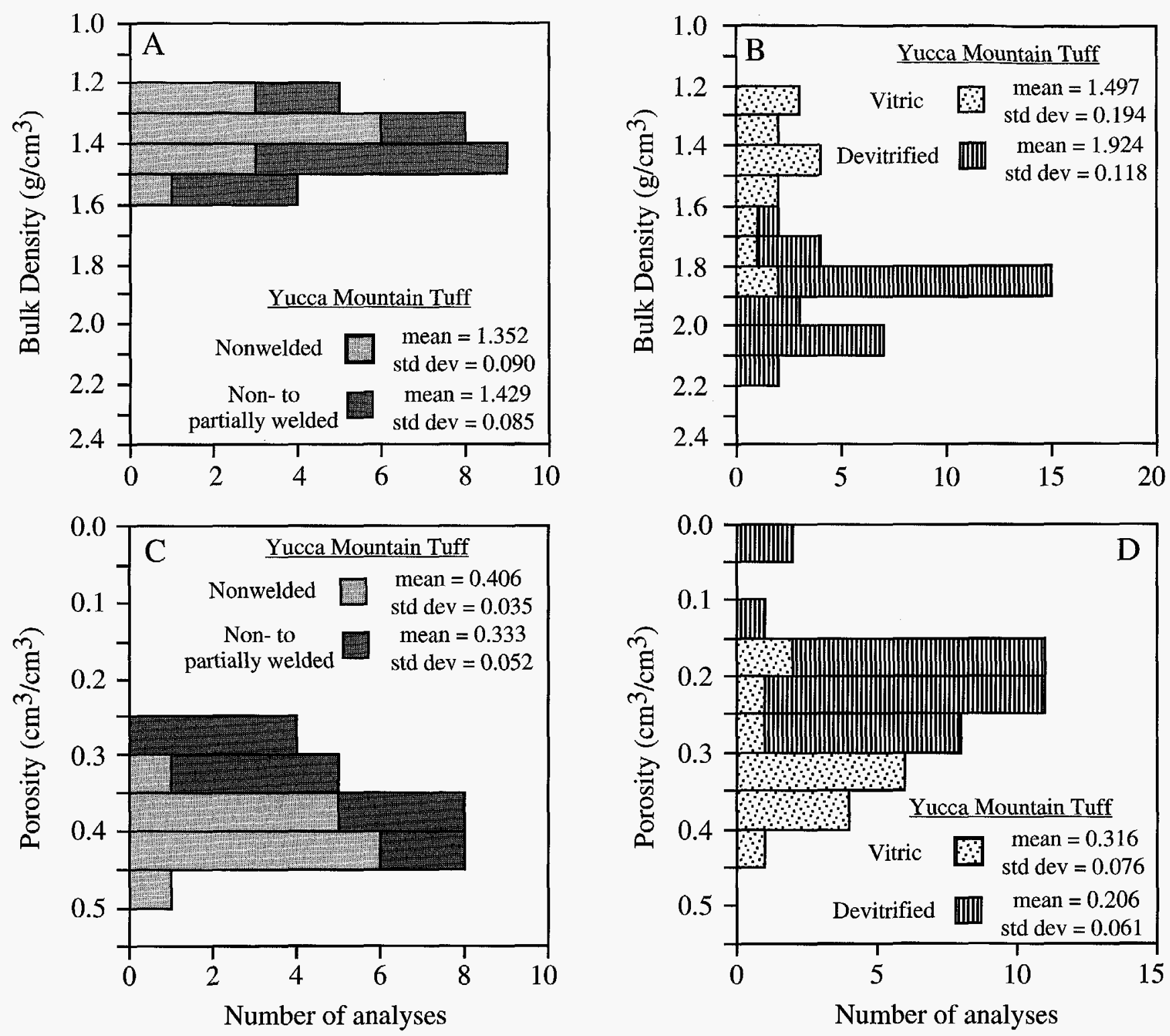

Figure 30. Histograms of hydrologic properties of the Yucca Mountain Tuff (Tpy) determined from borehole samples. A and C plot samples from vitric intervals: nonwelded includes data from boreholes UZ-N53, UZ-N54, UZ-N55, and UZ \#16; nonto partially welded include data from borehole SD-9. B and $D$ plot samples from intervals that vary from vitric to devitrified and include data from boreholes UZ-N11, UZ-N33, UZ-N34, and UZ-14. Density and porosity determined from relative humidity oven determinations; data are listed in appendix 4 


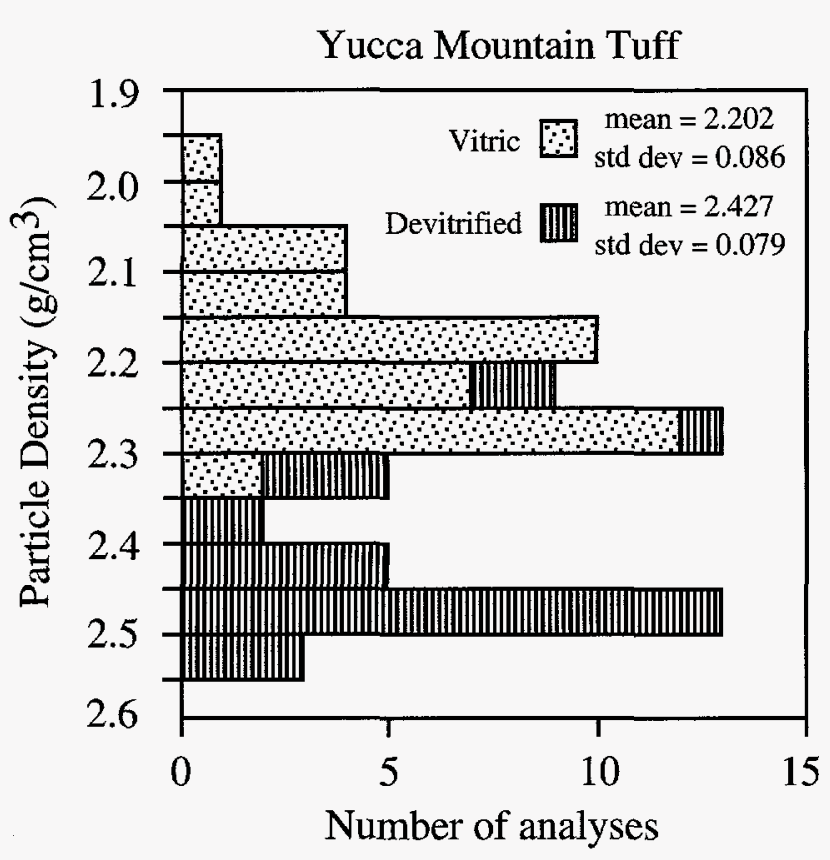

Figure 31. Histograms of particle density for the Yucca Mountain Tuff (Tpy). Bulk density determined at relative humidity (appendix 4).

Hydrologic properties of Yucca Mountain Tuff samples collected from exposures near Prow Pass are plotted in figure 36 . Density and porosity variations illustrate the welding profile. Note that the degree of welding increases gradually downward and that a thick zone of uniform welding overlies a thin basal zone in which welding decreases abruptly. Perturbations of the density and porosity profiles similar to those noted in borehole UZ-N33 are apparently absent, suggesting that the silicified zone previously discussed may not be regionally extensive. The percentage change in measured porosity (high temperature relative to determinations of relative humidity) increases slightly in the lower $10 \mathrm{~m}$ of the deposit, which, by analogy to borehole UZ-14, may reflect minor argillic or zeolitic alteration. Measured saturated hydraulic conductivity varies over four orders of magnitude and is estimated to have extremely low values $\left(10^{-11} \mathrm{~m} / \mathrm{s}\right)$ in the densely welded interior of the deposit (Flint and others, 1996).

The available data demonstrate that the hydrologic properties of Yucca Mountain tuff samples vary widely and are related to lithologic variations within the deposit. However, the present data are insufficient to establish the character, location, or hydrologic significance of the abrupt transition from welded, devitrified tuff to non- to partially welded, vitric tuff.

\section{Pre-Yucca Mountain Tuff Bedded Tuffs (Tpbt3)}

Units within the pre-Yucca Mountain Tuff bedded tuffs, with the exception of unit $E$, are typically thin (appendix 3) and are nonwelded pumice-fall deposits that should have similar hydrologic properties. Therefore, for the purposes of this discussion, the entire Tpbt3 is treated as one unit. Hydrologic properties were measured for samples of the pre-Yucca Mountain Tuff bedded tuffs collected from nine boreholes drilled since 1991 (appendix 4).

\section{General Hydrologic Properties}

Porosity and bulk density data of pre-Yucca Mountain Tuff bedded tuff samples are shown in figure 37 . These plots show that the hydrologic properties are fairly consistent throughout Tpbt3. These samples have average porosity of nearly 39 percent and average bulk density of $1.42 \mathrm{~g} / \mathrm{cm}^{3}$ (fig. 37). In the hydrologic models discussed below, the pre-Yucca Mountain Tuff bedded tuffs are represented by model layer BT3, which was assigned a porosity of 38 percent (table 2).

A sample from unit $\mathrm{E}$ in borehole $\mathrm{UZ}-14$ has a porosity of 41.8 percent and a bulk density of $1.33 \mathrm{~g} / \mathrm{cm}^{3}$, values that are similar to other samples in Tpbt3 (appendix 4). This suggests that the hydrologic properties of the pre-Yucca Mountain Tuff bedded tuffs will be approximately the same in the northern part of Yucca Mountain where unit E and Tpbt 3 reach their greatest thickness.

\section{Pah Canyon Tuff (Tpp)}

Hydrologic properties were measured in six boreholes that contain intervals of the Pah Canyon Tuff (appendix 4). These boreholes capture complete sections of nonwelded, vitric Pah Canyon Tuff. Hydrologic-property measurements from borehole samples are not available for intervals in which the Pah Canyon Tuff varies downward from vitric to altered (borehole NRG \#4) or from vitric, nonwelded to devitrified, welded (borehole G-2). However, hydrologic properties were reported for surface samples collected through a sequence of welded Pah Canyon Tuff south of Yucca Wash near Prow Pass (Flint and others, 1996). 


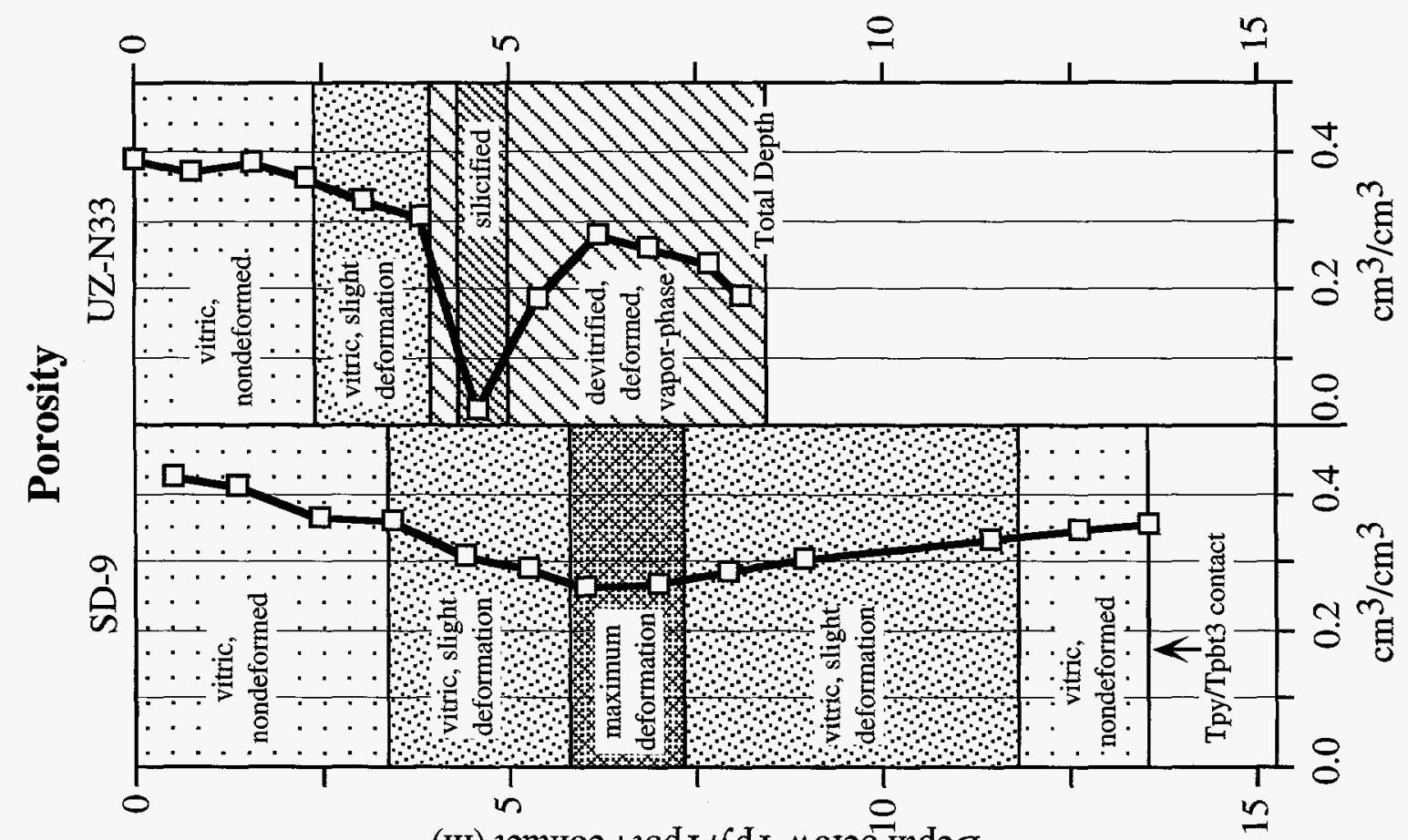

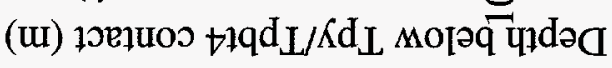

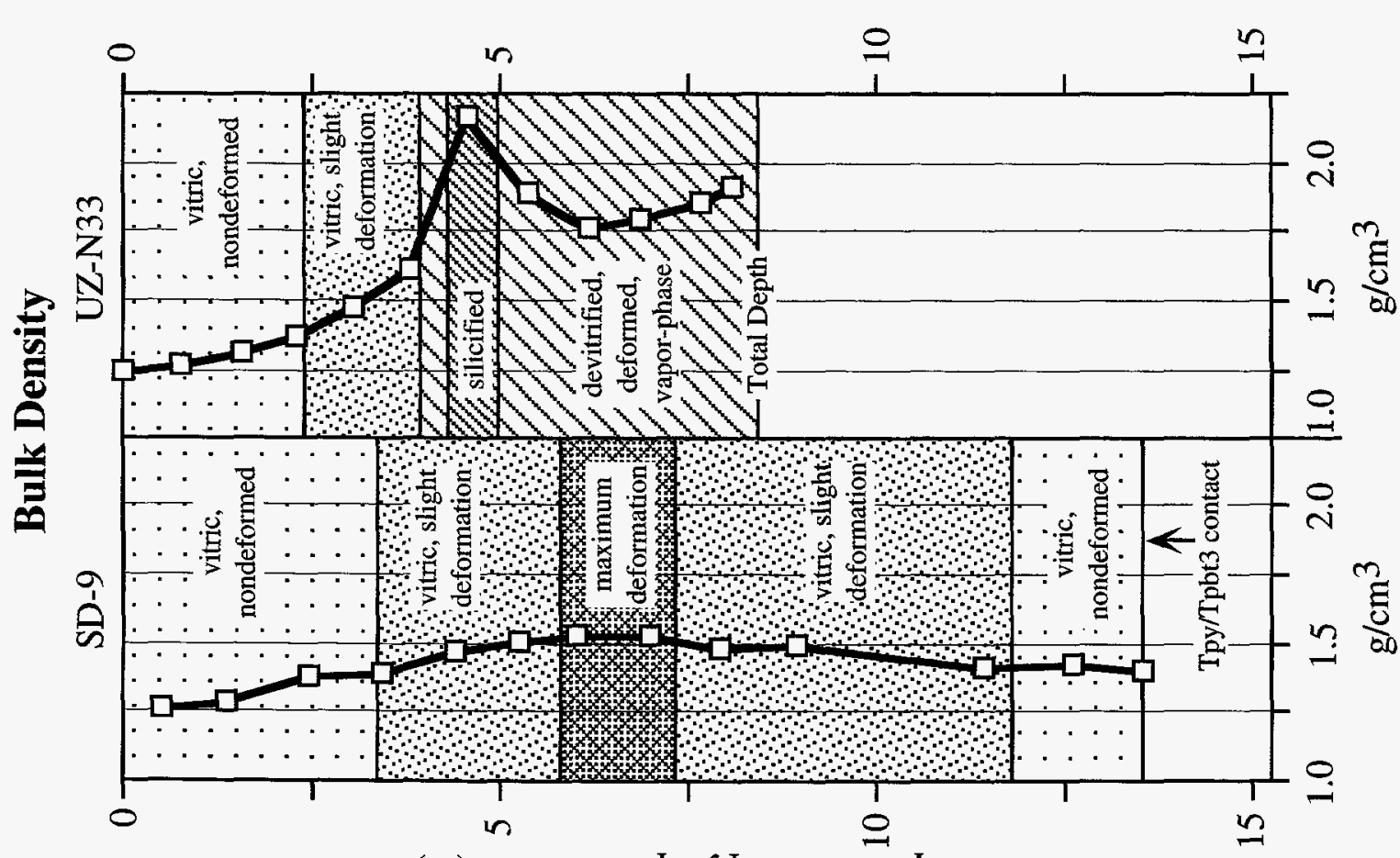

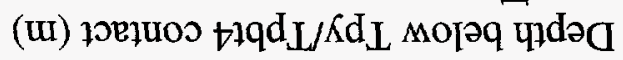

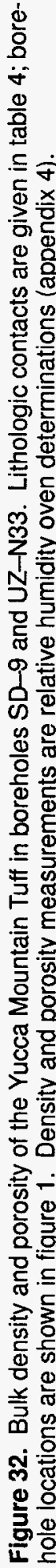

66 Stratigraphic Relations and Hydrologic Properties of the Paintbrush Tuft Nonwelded (PTn) Hydrologic Unit, Yucca Mountain, Nevada 


\section{Borehole UZ-14}

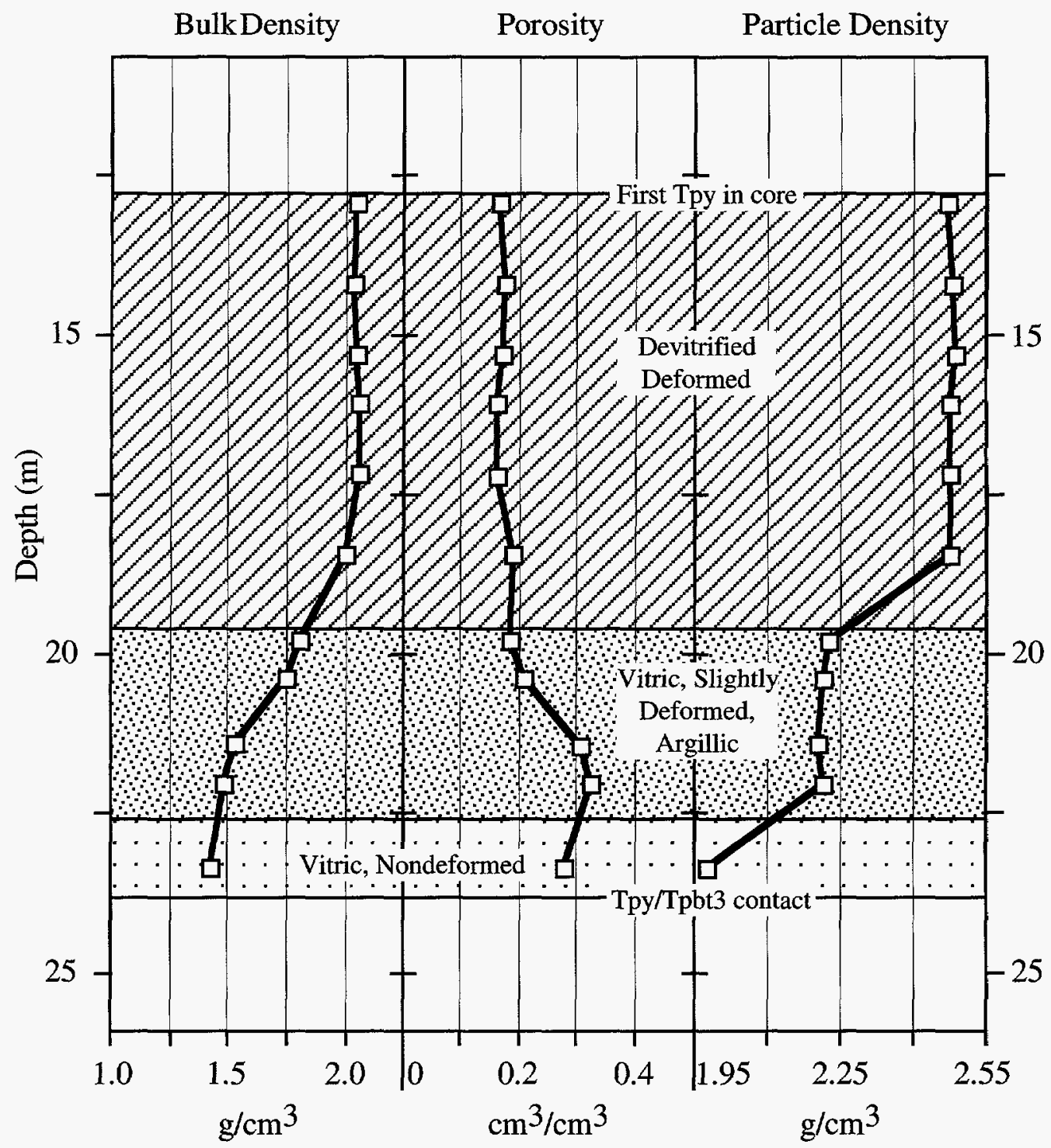

Figure 33. Bulk density, porosity, and particle density of the Yucca Mountain Tuff (Tpy) in borehole UZ-14. Lithologic contacts are given in table 4; borehole location is shown in figure 1. Hydrologic-property measurements are relative humidity oven determinations (appendix 4). Note the decrease in bulk density and increase in porosity toward the base of the unit and the abrupt decrease in particle density at the devitrified-vitric boundary.

\section{General Hydrologic Properties}

Compiled hydrologic properties for the Pah Canyon Tuff recovered in boreholes and collected from outcrops are shown in figure 38 . Histograms of Pah Canyon Tuff property measurements illustrate that the bulk densities of borehole samples typically vary from 1.0 to $1.3 \mathrm{~g} / \mathrm{cm}^{3}$ and that pore space commonly forms 40 to 60 percent of the tuff. Samples of welded and devitrified Pah Canyon Tuff from the Yucca Wash traverse have significantly higher density $\left(1.6\right.$ to $\left.2.2 \mathrm{~g} / \mathrm{cm}^{3}\right)$ and lower porosity (less than 30 percent). As expected, the welded and nonwelded Pah Canyon Tuff samples have distinctly different particle densities (fig. 38). 


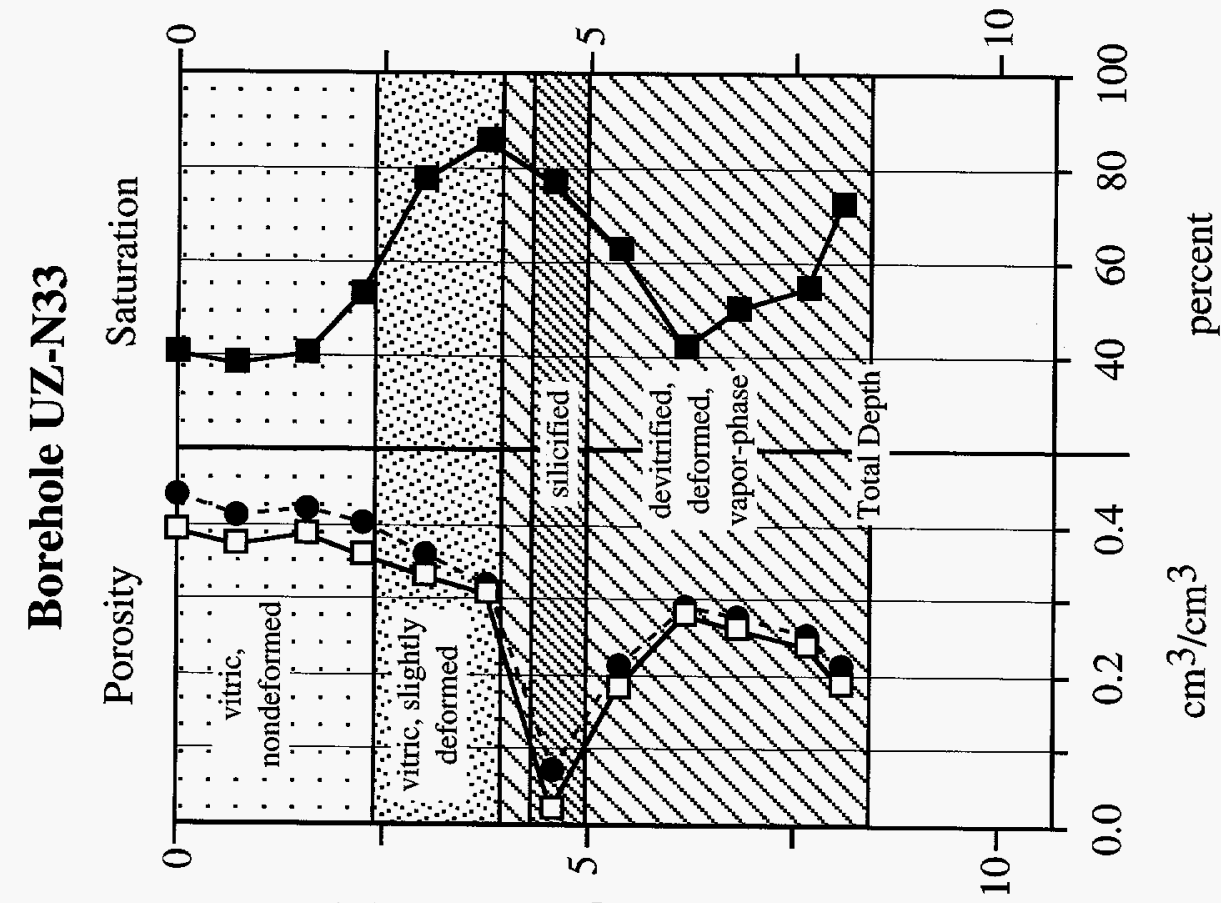

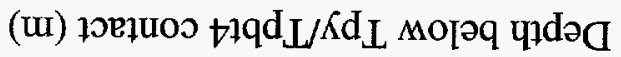

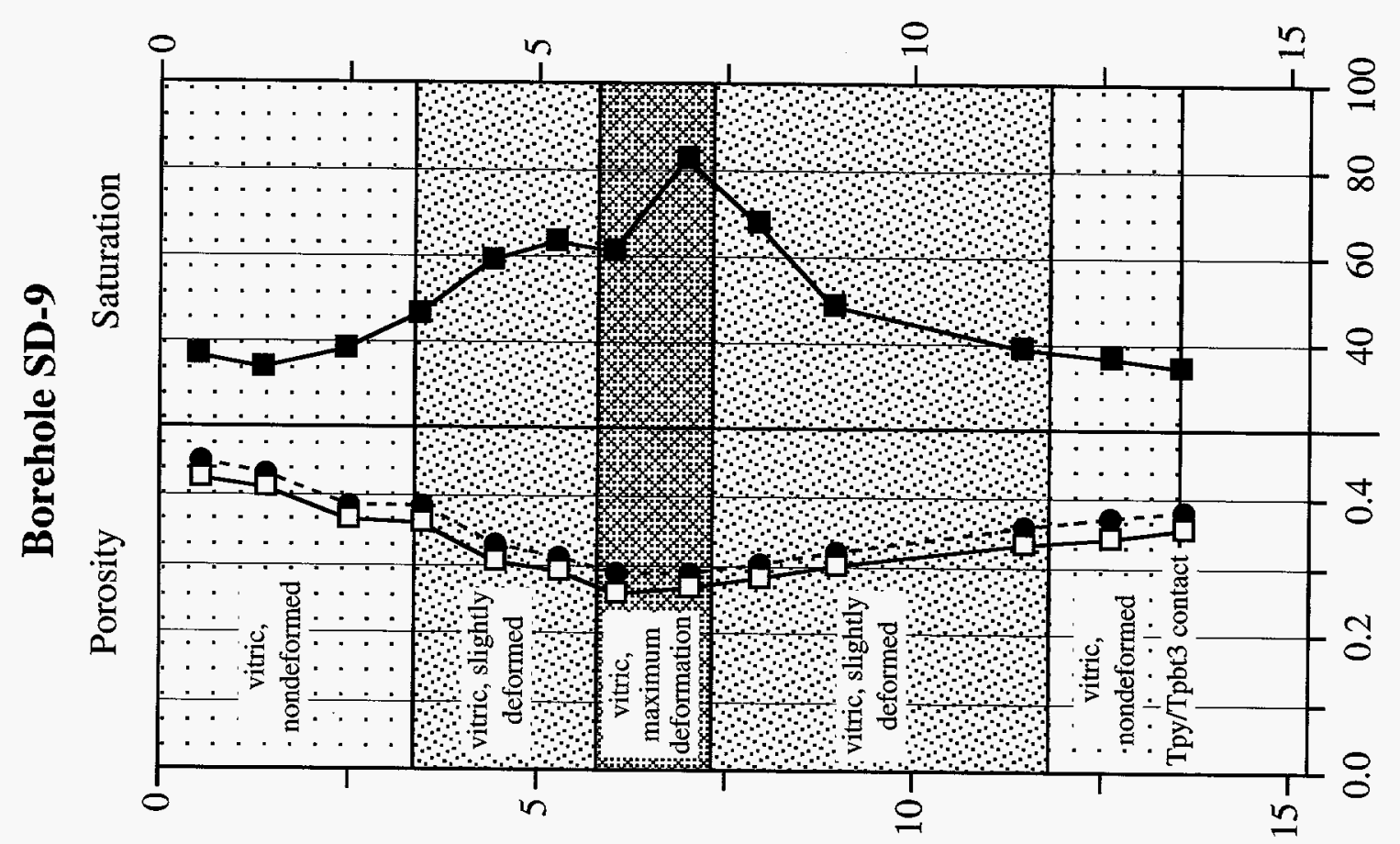

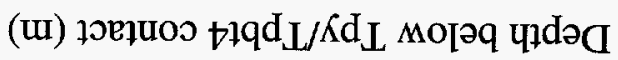

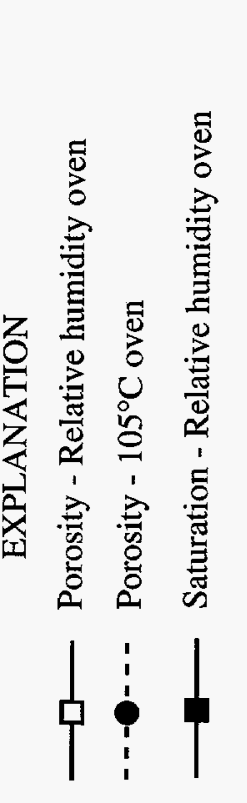

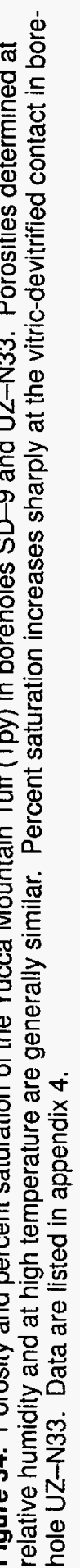




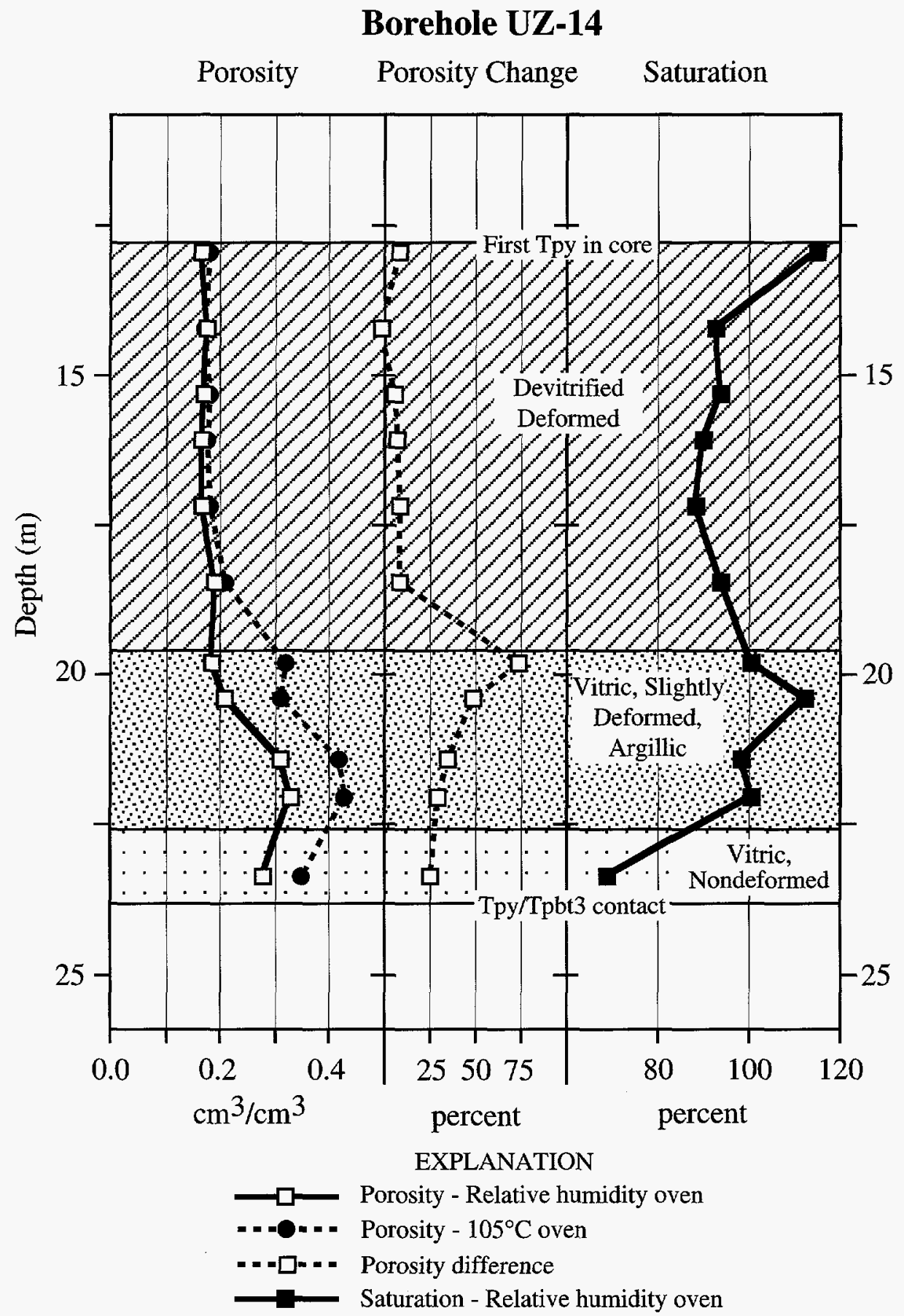

Figure 35. Porosity and saturation of the Yucca Mountain Tuff in borehole UZ-14. Porosities determined at relative humidity and at high temperature are generally similar in the devitrified portion of the deposit, but differ markedly where argillic alteration is macroscopically prominent. Porosity change plots the percent increase in porosity determined at high temperature (appendix 4). 


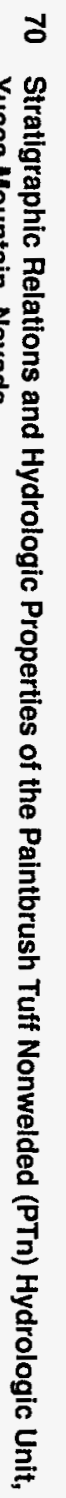

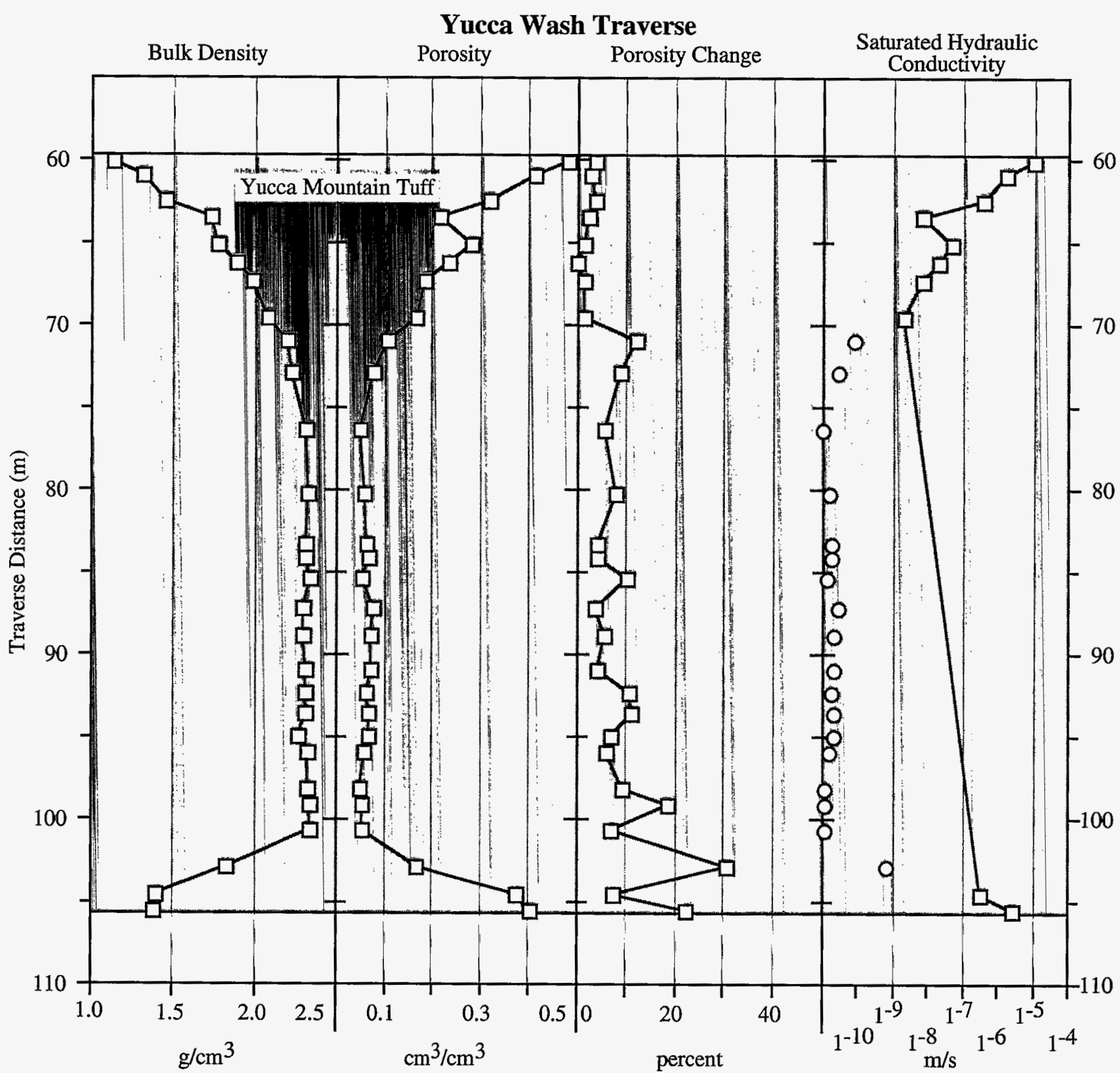

Figure 36. Hydrologic properties of the Yucca Mountain Tuff in a stratigraphic section near Prow Pass, plotted relative to traverse distance (stratigraphic thickness) (Flint and others, 1996). Saturated hydraulic conductivity: open squares are measured values; open circles are estimates. Compare with figures 32 and 33 . All properties determined at relative humidity. 

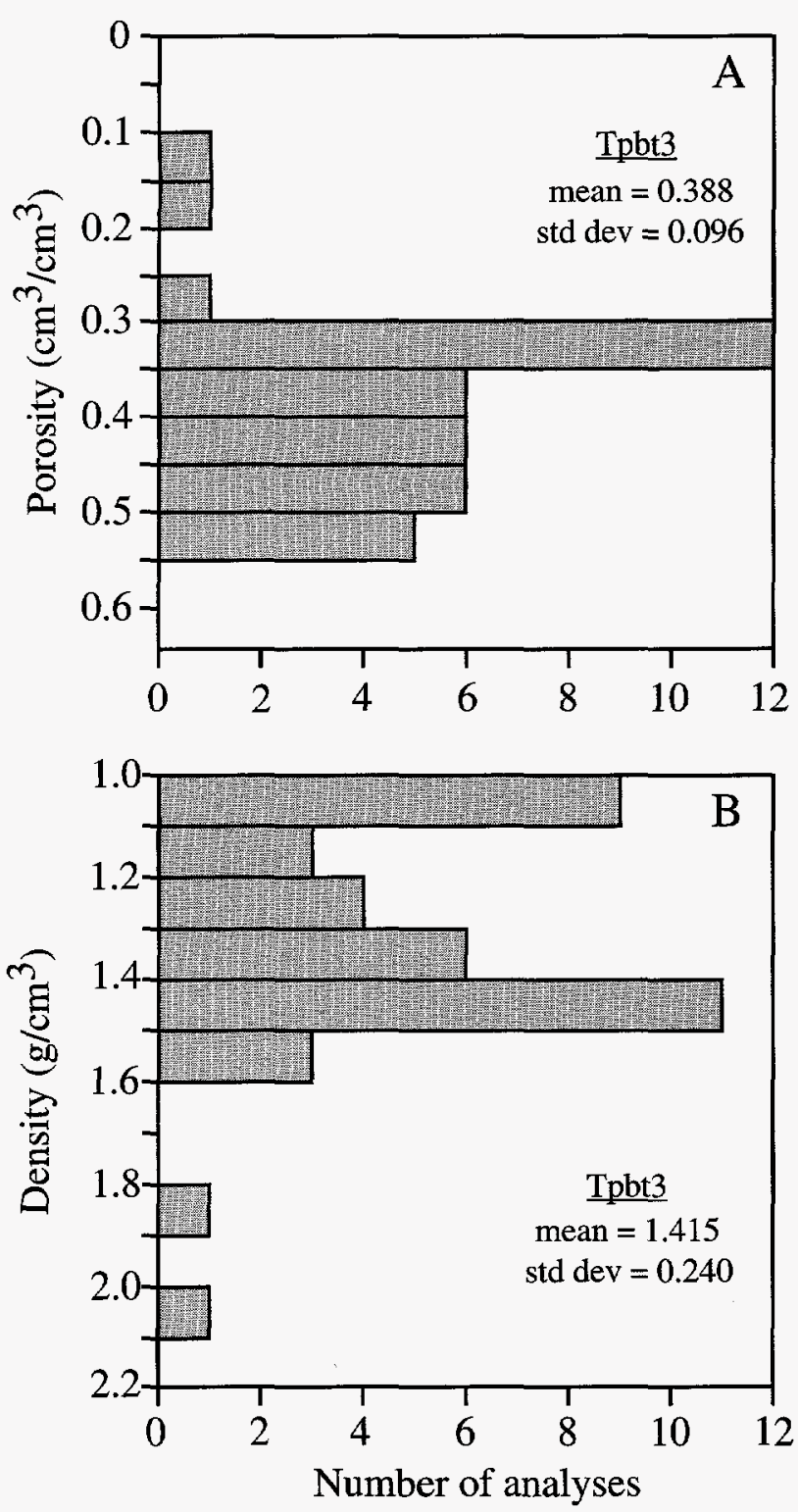

Figure 37. Porosity and bulk density histograms for the pre-Yucca Mountain Tuff bedded tuffs (Tpbt3). Porosity and bulk density determined at relative humidity (appendix 4).

\section{Stratigraphic Controls on Hydrologic Properties}

The welding, crystallization, and alteration history of the Pah Canyon Tuff produces significant, but poorly characterized, variations in hydrologic properties. Figure 39 shows vertical variations in density, porosity, and percent porosity change in boreholes UZ-14 and SD-9. In both examples, physical properties are consistent through the stratigraphic section and do not vary with changes in pumice-clast type (see the section on stratigraphic relations). Note that (with one data point excepted) porosity determined at high temperature is only slightly greater than that determined at relative humidity (generally less than 10 to 12 percent), suggesting that argillic or zeolitic alteration of vitric Pah Canyon Tuff is minimal to absent in the study area.

The Pah Canyon Tuff is welded and devitrified in borehole $\mathrm{G}-2$, for which hydrologic-property data are lacking. However, hydrologic properties were measured for a suite of samples collected from a section of welded Pah Canyon Tuff exposed along Yucca Wash near Prow Pass (Flint and others, 1996). The density and porosity variations, which illustrate the welding profile (fig. 40), depict a formation that is less intensely and less uniformly welded than the Yucca Mountain Tuff (compare fig. 36). The percent porosity change plotted on figure 40 varies significantly in the lower third of the traverse, with values that exceed 40 percent. This feature is consistent with an increase in secondary hydrous minerals noted by Broxton and others (1993) for a section of Pah Canyon Tuff sampled approximately $700 \mathrm{~m}$ northwest of borehole G-2. These workers found that clinoptilolite and mordenite compose approximately 75 weight percent of the lower Pah Canyon Tuff. The presence of secondary minerals may explain the unusual trend displayed by saturated hydraulic conductivity, which decreases with depth despite an increase in porosity in the lower part of the deposit.

The available data demonstrate that the Pah Canyon Tuff varies significantly in its hydrologic properties. The deposit, as observed in core from borehole $\mathrm{G}-2$, shares many lithologic attributes with welded intervals of the Yucca Mountain Tuff, including a silicified zone near the upper vitric-devitrified contact. Unfortunately, the present data are insufficient to either establish the character, location, and hydrologic significance of the welded to nonwelded transition or to evaluate the hydrologic and geologic significance of the zone of secondary mineralization discussed above.

\section{Pre-Pah Canyon Tuff Bedded Tuffs (Tpbt2) and Non- to Partially and Moderately Welded Subzones of the Topopah Spring Tuff Crystal-Rich Vitric Zone (Tptrv3, Tptrv2)}

Hydrologic properties were measured in 10 boreholes that contain whole or partial sections of the interval from the base of the Pah Canyon Tuff to the top of the Topopah Spring Tuff crystal-rich vitrophyre (appendix 4). These boreholes contain 

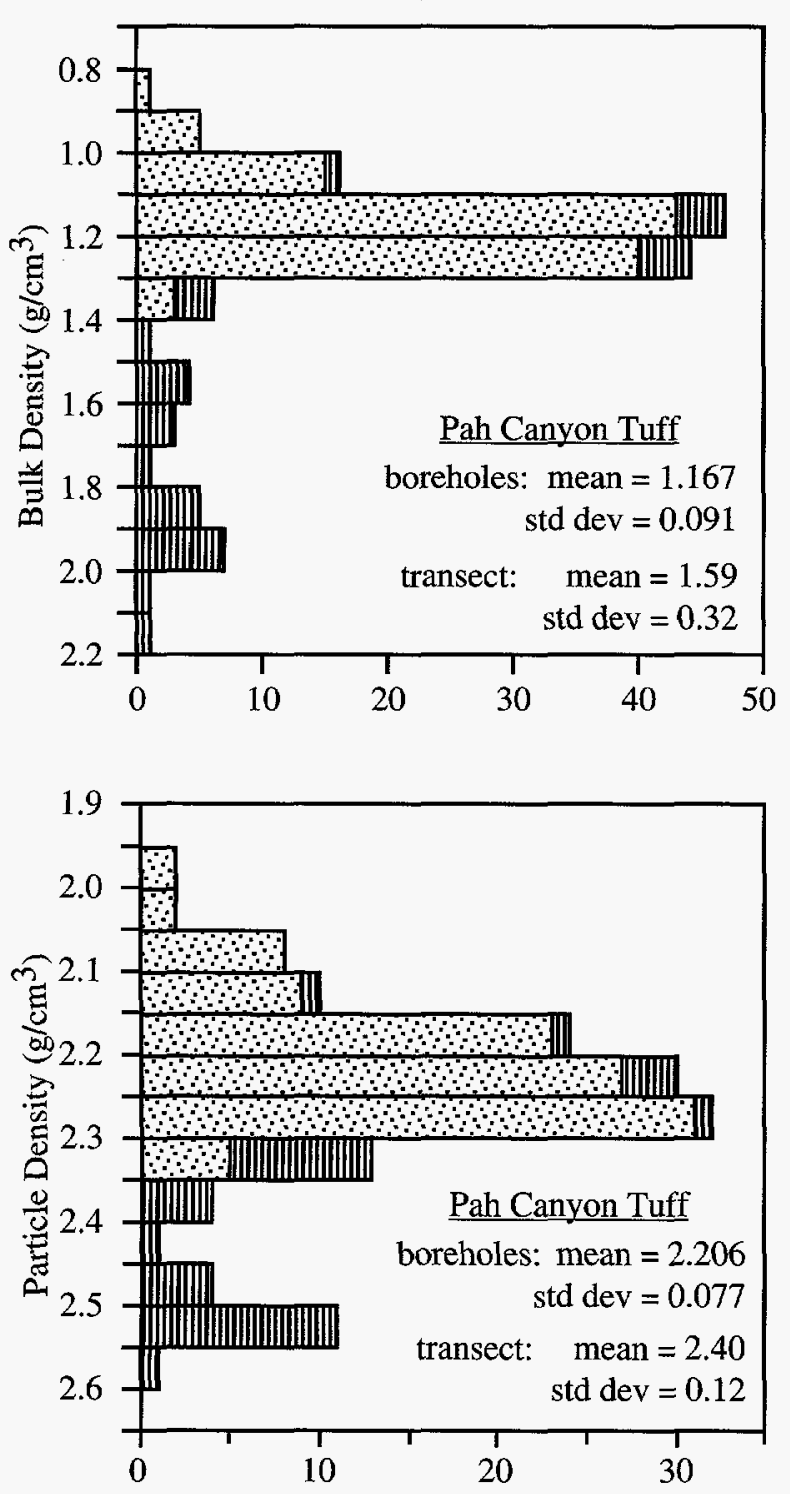

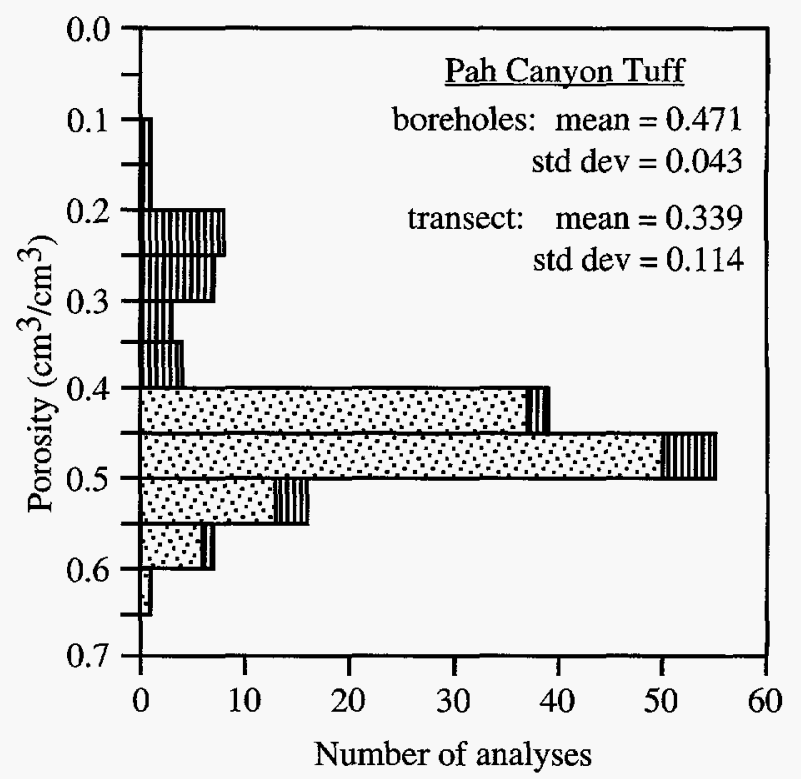

\section{EXPLANATION}

Borehole samples

IIIII Yucca Wash traverse samples

(Flint and others, 1996)

Number of analyses

Figure 38. Histograms of hydrologic properties of the Pah Canyon Tuff determined from borehole and outcrop samples. All properties determined at relative humidity. Borehole data are listed in appendix 4; traverse data are from Flint and others (1996).

stratigraphic sections of vitric to variably altered tuff that is predominantly nonwelded. Hydrologic properties were reported for surface samples collected through the interval south of Yucca Wash near Prow Pass and along the eastern side of Solitario Canyon (Flint and others, 1996).

\section{General Hydrologic Properties}

Compiled hydrologic properties for the interval from the base of the Pah Canyon Tuff to the top of the Topopah Spring Tuff crystal-rich vitrophyre are plotted in figures 41 and 42 . Histograms of these analyses illustrate that unit $\mathrm{D}$, which possibly is reworked, has slightly higher bulk density and lower porosity than the underlying pumice-fall deposits of units $\mathrm{C}$ and $\mathrm{B}$ $\left(1.4 \mathrm{~g} / \mathrm{cm}^{3}\right.$ compared to $1.1 \mathrm{~g} / \mathrm{cm}^{3}$ and 39 percent compared to approximately 50 percent, respectively). Note that samples collected from the argillically altered top of unit $C$ have higher density and lower porosity than vitric samples of unit $\mathrm{C}$. The bulk density and porosity of the non- to partially welded to moderately welded pumice-fall deposits of unit $A$ vary from values similar to those of units $B$ and $C$ to values consistent with an increased degree of welding. 


\section{Pah Canyon Tuff}

\section{Borehole UZ-14}

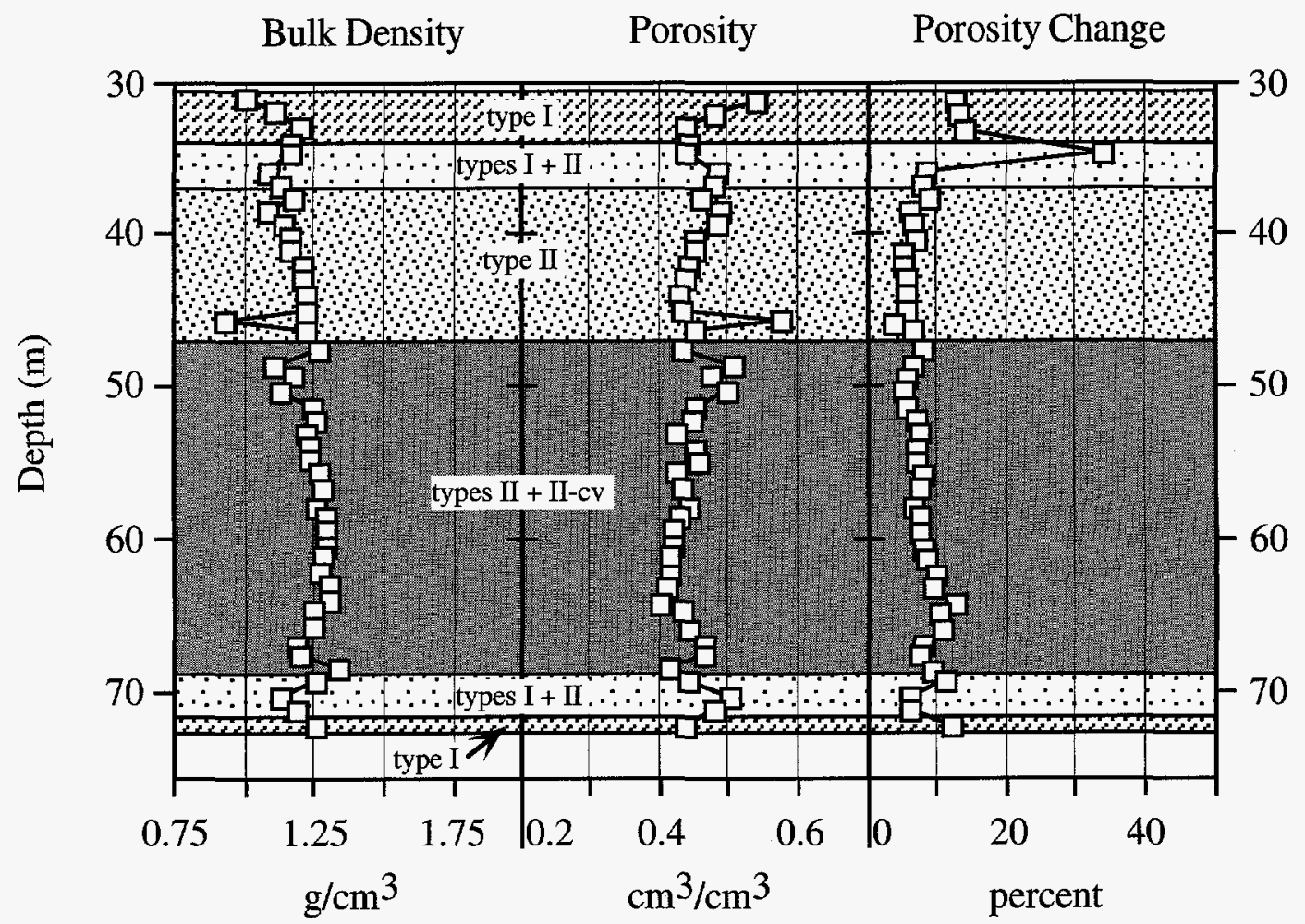

\section{Borehole SD-9}

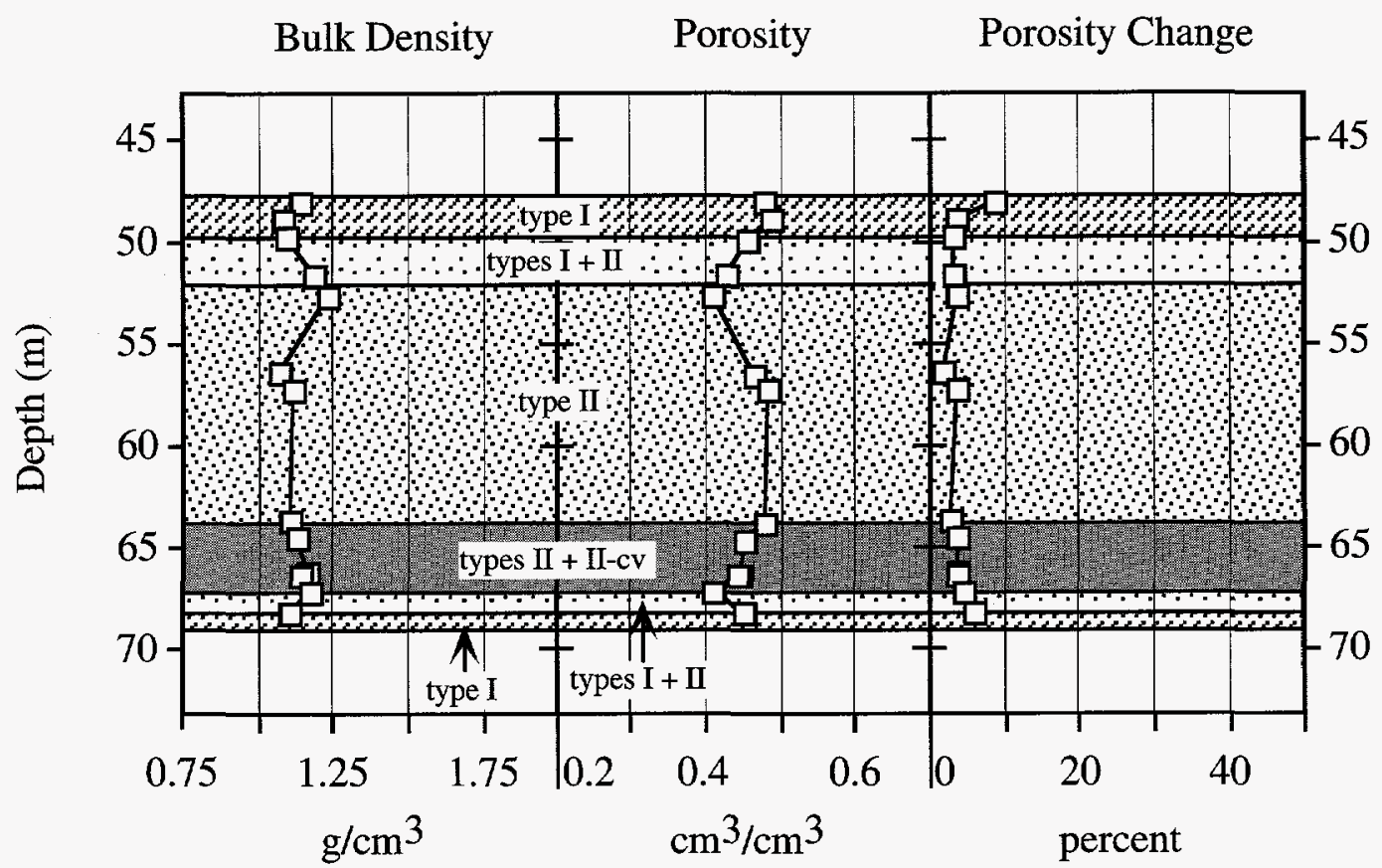

Figure 39. Bulk density and porosity of the Pah Canyon Tuff in boreholes SD-9 and UZ-14. Properties measured at relative humidity (appendix 4). Contacts showing changes in pumice-clast types are from table 5 . Porosity change plots the percent increase in porosity determined at high temperature (appendix 4). 


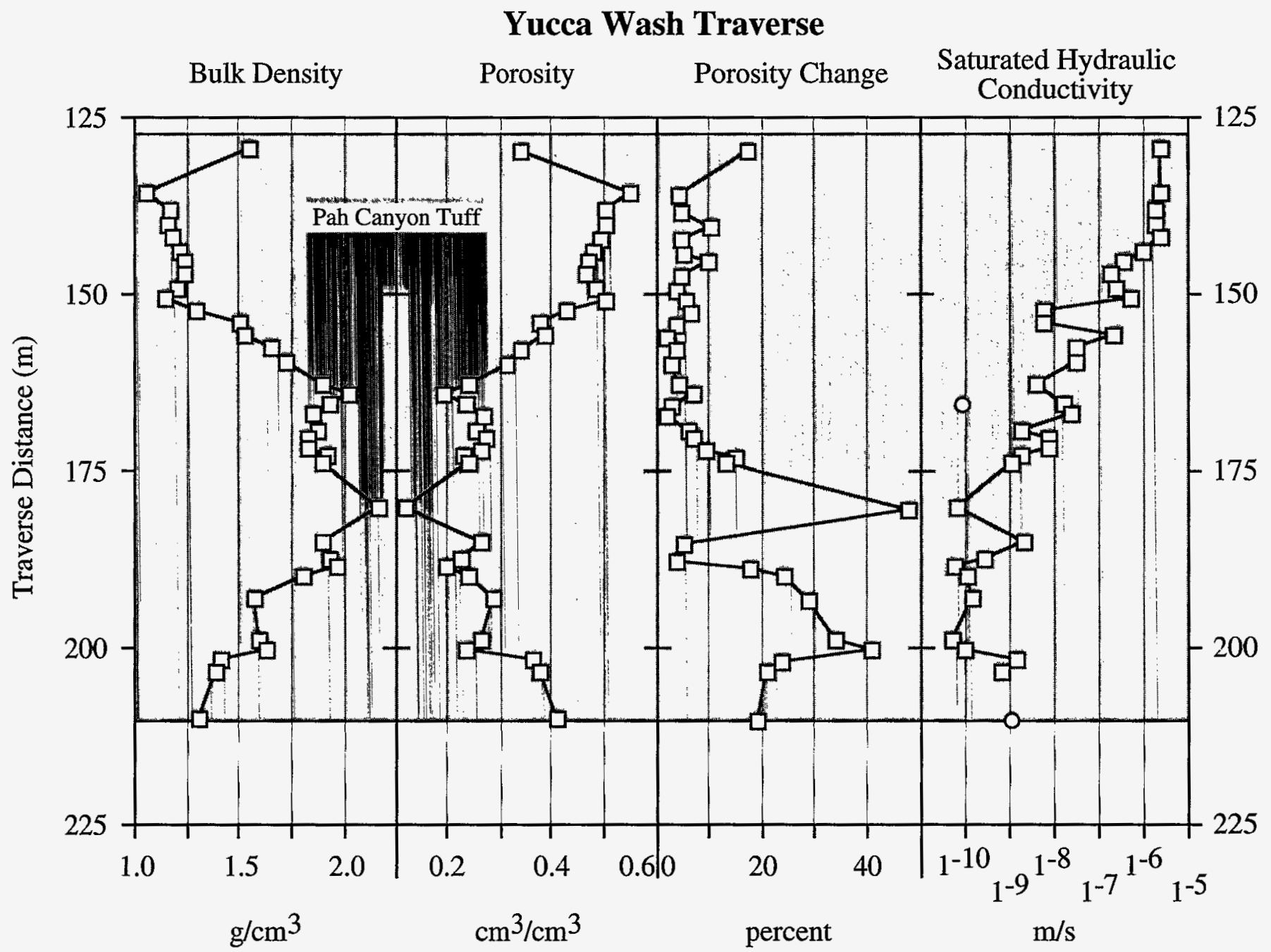

Figure 40. Hydrologic properties of the Pah Canyon Tuff in a stratigraphic section near Prow Pass, plotted relative to traverse distance (stratigraphic thickness) (Flint and others, 1996). Saturated hydraulic conductivity: open squares are measured values; open circles are estimates. Note increase in porosity change in lower part of deposit and downward decrease in saturated hydraulic conductivity despite increasing porosity in the lower part of the deposit. Compare with figure 39. All properties determined at relative humidity. 

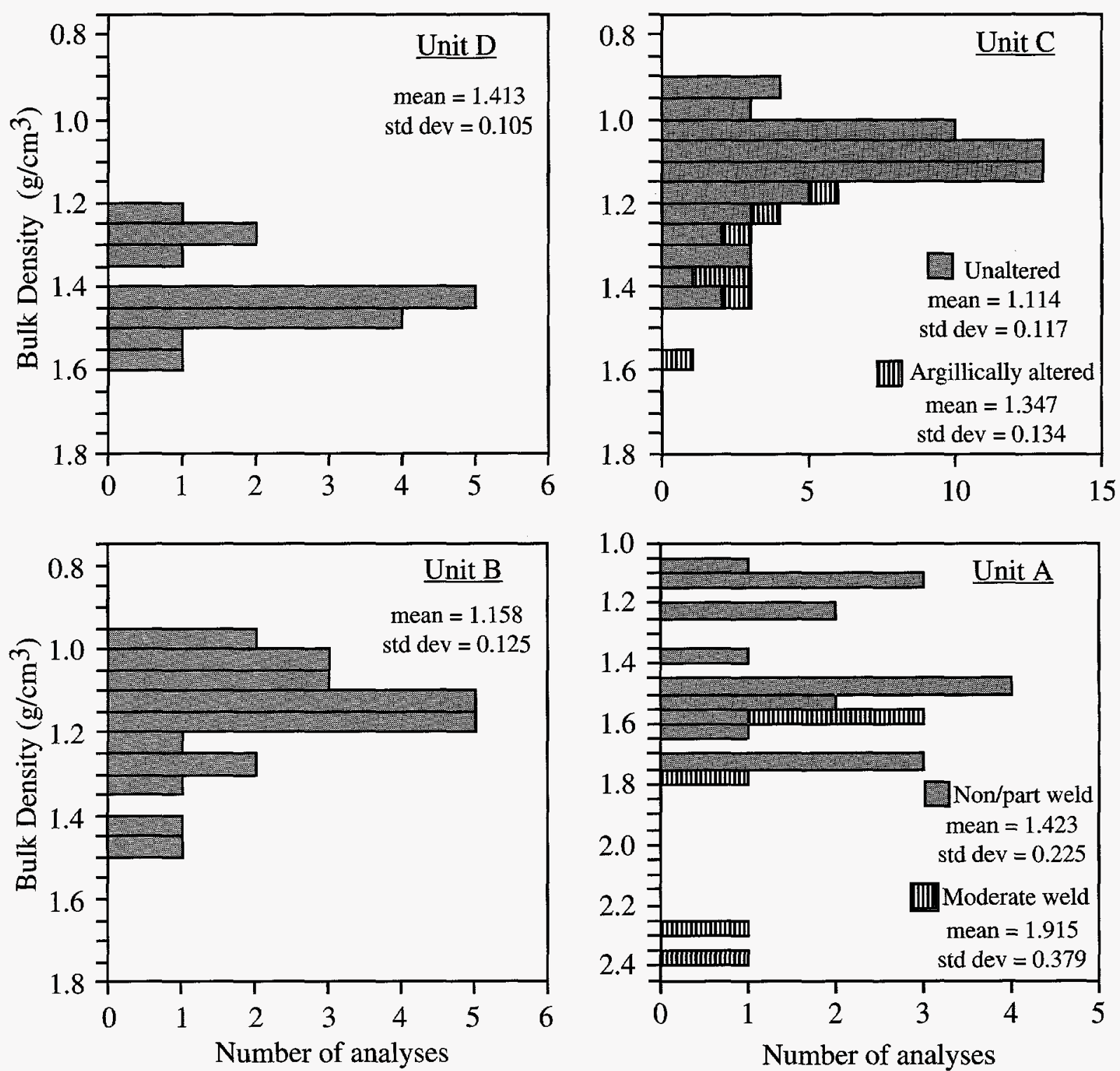

Figure 41. Histograms of bulk density for the interval from the base of the Pah Canyon Tuff to the top of the Topopah Spring Tuff crystal-rich vitrophyre. Data are relative humidity oven determinations for borehole samples listed in appendix 4.

\section{Stratigraphic Controls on Hydrologic Properties}

The depositional, welding, and alteration histories of the interval from the base of the Pah Canyon Tuff to the top of the Topopah Spring Tuff crystal-rich vitrophyre produces slight vertical variations in hydrologic properties. Figures 43,44 , and 45 illustrate subtle vertical variations in hydrologic properties that are observed in boreholes UZ-N32, SD-9, and UZ-N54. In these figures, a slight change in porosity and bulk density occurs at or near the unit D-unit $C$ lithologic contact. Note also that, with the exception of the upper 1 to $2 \mathrm{~m}$ of unit $\mathrm{C}$ in borehole UZ-N32, the hydrologic properties of units $\mathrm{C}$ and $\mathrm{B}$ are remarkably invariant with depth. The marked deviation in properties observed at the top of unit $\mathrm{C}$ in borehole UZ-N32 coincides with an interval of intense argillic alteration and illustrates the effect of argillization on the hydrologic properties of this pumice-fall deposit (fig. 43).

The increase in welding observed in the basal 1 to $2 \mathrm{~m}$ of unit $\mathrm{A}$ in boreholes UZ-N32 and SD-9 (figs. 40 and 44 ) creates an abrupt, but gradational, change to hydrologic properties consistent with dense welding. In these examples, unit A lies atop the crystal-rich vitrophyre of the Topopah Spring Tuff. 

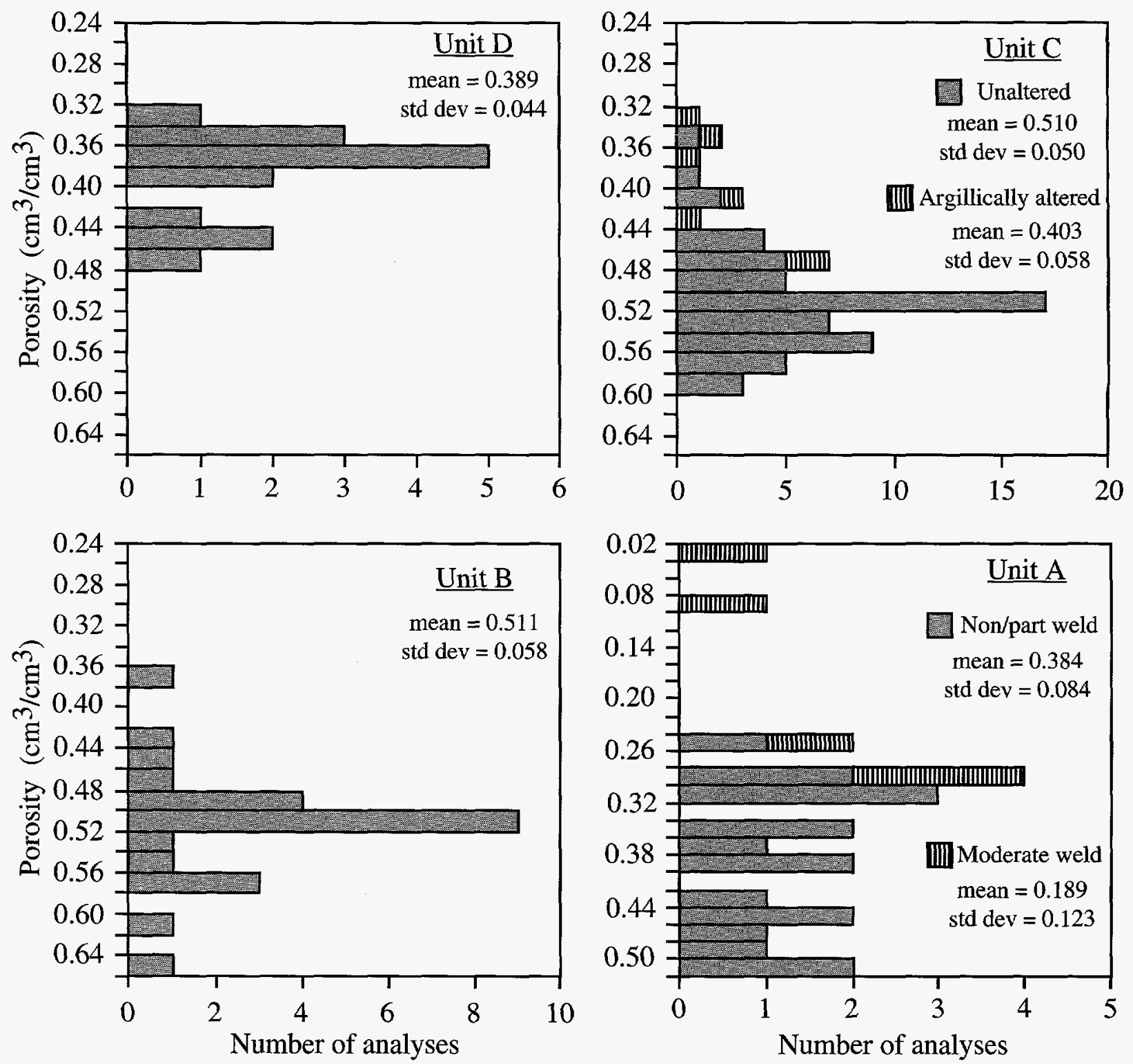

Figure 42. Histograms of porosity for the interval from the base of the Pah Canyon Tuff to the top of the Topopah Spring Tuff crystal-rich vitrophyre. Data are relative humidity oven determinations for borehole samples listed in appendix 4.

The situation is more complex in borehole UZ-N54, where unit A overlies moderately welded, devitrified, and vapor-phase altered pyroclastic-flow material (fig. 45). In this case, unit $A$ is nonwelded to partially welded throughout and the abrupt change to hydrologic properties consistent with dense welding occurs within pyroclastic-flow material. The fall-flow contact in borehole UZ-N54 coincides with a slight change in particle densities from values generally below $2.5 \mathrm{~g} / \mathrm{cm}^{3}$ above the contact to values generally above $2.5 \mathrm{~g} / \mathrm{cm}^{3}$ below the contact (appendix 4).
Saturated hydraulic conductivity was measured or estimated for outcrop and borehole samples collected from the interval between the base of the Pah Canyon Tuff and the top of the Topopah Spring Tuff crystal-rich vitrophyre (Flint and others, 1996; L.E. Flint, unpub. data, 1995). These data are plotted on figure 28 , which illustrates that hydraulic conductivity in this interval is comparatively high and varies by slightly more than one order of magnitude $(6.6 \mathrm{E}-7$ to $1.7 \mathrm{E}-5 \mathrm{~m} / \mathrm{s}$ ). 







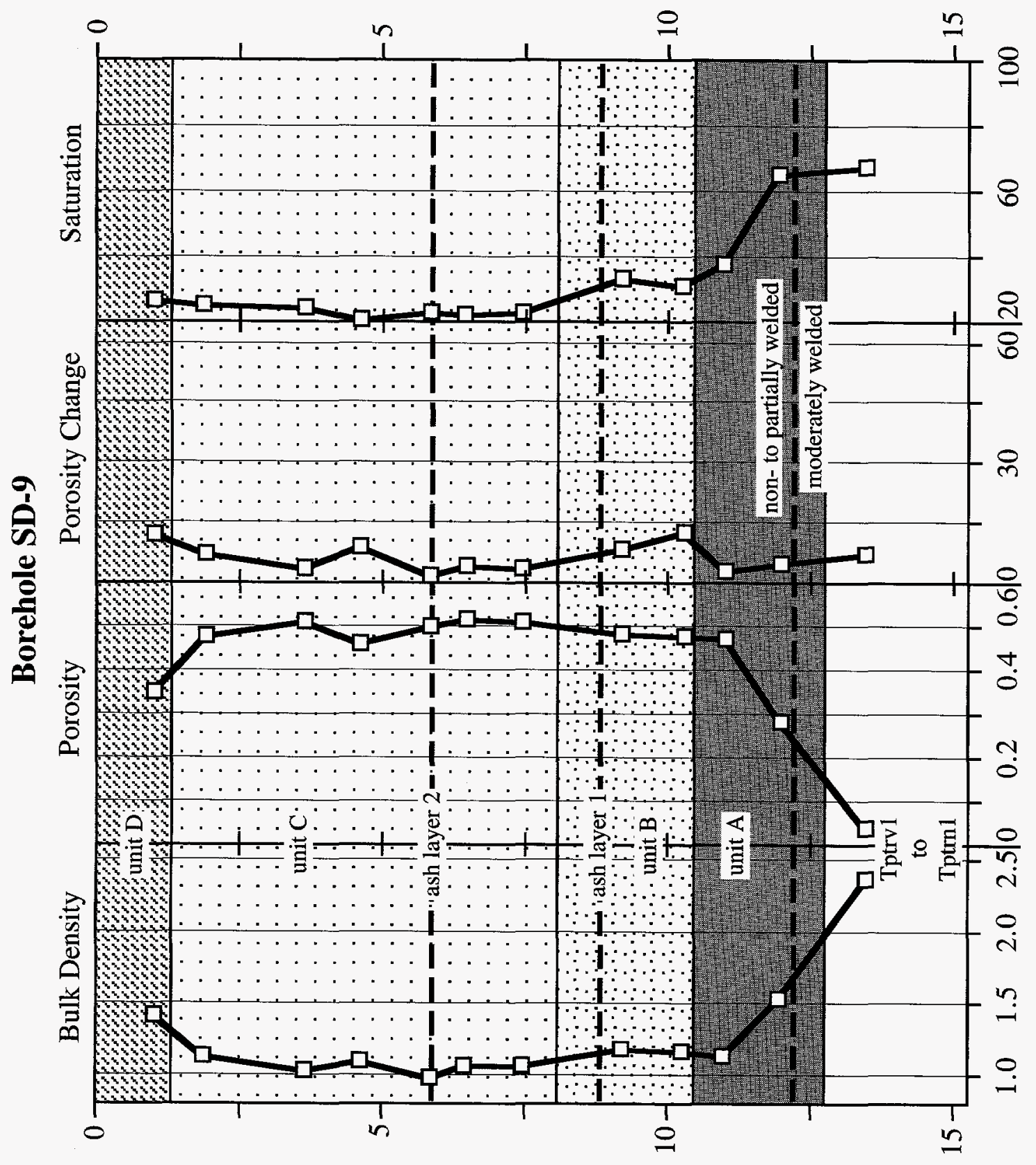

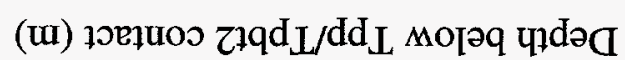

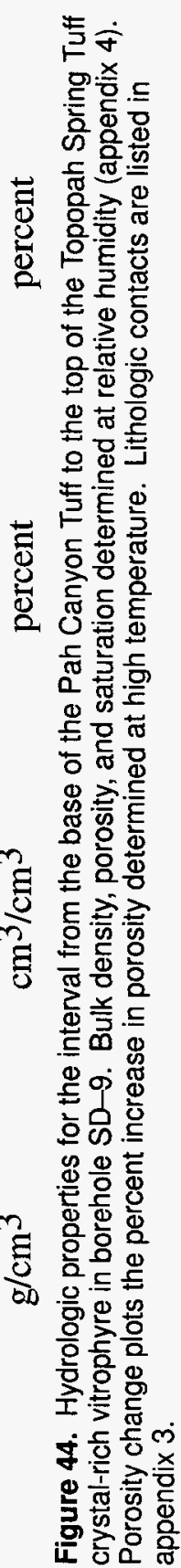

78 Stratigraphic Relations and Hydrologic Properties of the Paintbrush Tuff Nonwelded (PTn) Hydrologic Unit, Yucca Mountain, Nevada 


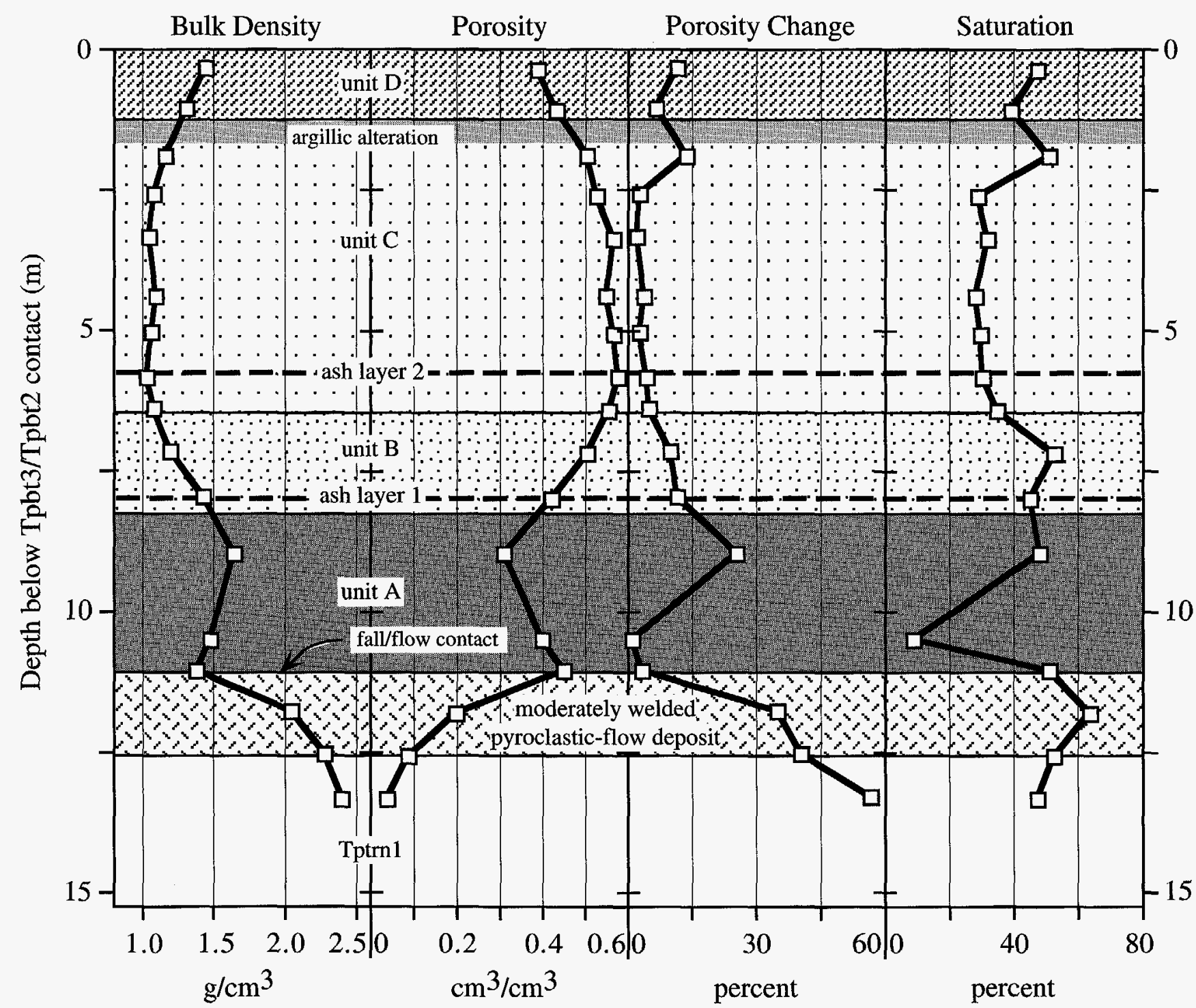

Figure 45. Hydrologic properties for the interval from the base of the Pah Canyon Tuff to the top of the Topopah Spring Tuff crystal-rich vitrophyre in borehole UZ-N54. Bulk density, porosity, and saturation determined at relative humidity (appendix 4). Porosity change plots the percent increase in porosity determined at high temperature. Lithologic contacts are listed in appendix 3. 


\section{REGIONAL HYDROLOGIC-PROPERTY VARIATIONS}

Bulk density and porosity profiles illustrate the general character of the PTn unit. Figure 46 shows three profiles constructed from borehole data. The northern section merges profiles from boreholes UZ-N33 and UZ-14 in order to produce a complete composite section.

Several features observed on the profiles in figure 46 are representative of the regional character of the PTn unit. In general, the PTn strata have low density and high porosity when compared to the enclosing densely welded Tiva Canyon and Topopah Spring Tuffs. However, the upper and lower contacts of the PTn unit are decidedly different. At the upper contact, the change from densely welded to nonwelded material grades over a vertical distance of 7 to $15 \mathrm{~m}$. In contrast, the variation in welding at the lower contact is abrupt and typically occurs over a vertical distance of less than $3 \mathrm{~m}$. These differences in welding produce asymmetric profiles of saturated hydraulic conductivity at the upper and lower contacts (fig. 28, borehole UZ \#16).

The thick pumice-fall deposits that overlie the Topopah Spring Tuff (units Tptrv3 and Tpbt2) are the most porous units in the section, with values that typically fall between 50 and 60 percent. Figure 28 shows that these deposits have the highest measured saturated hydraulic conductivity in the PTn section. The nonwelded Pah Canyon Tuff plotted in figure 46 also is highly porous, with values that fall typically between 40 and 50 percent. The Pah Canyon Tuff and post-Topopah Spring Tuff pumice-fall deposits are separated by a thin interval of significantly less porous material that comprises the (possibly) reworked material of unit $D$ and the argillically altered top of unit $C$ of the pre-Pah Canyon Tuff bedded tuffs. The consistent porosity and density of the Pah Canyon Tuff and the post-Topopah Spring Tuff pumice-fall deposits contrasts with the variable character of the other bedded tuffs in the PTn section (Tpbt3 and Tpbt4). The composite UZ-N33/UZ-14 profile (fig. 46) shows a marked change in the character of the PTn unit where the section includes welded Yucca Mountain Tuff.
In this section, the Yucca Mountain Tuff has less than 20-percent porosity and deviates significantly from the remaining PTn units.

The Yucca Mountain Tuff is the only PTn unit with hydrologic properties that are documented to vary laterally. The significant variation in the properties of the Yucca Mountain Tuff mirror the welding and secondary crystallization history of the tuff sheet. The Pah Canyon Tuff exhibits a similar zonation in macroscopic welding and secondary crystallization and, presumably, has properties that vary laterally in a similar manner.

\section{RESULTS OF PRELIMINARY HYDROLOGIC FLOW MODELS}

Two-dimensional flow was numerically modeled along two cross sections constructed between boreholes. The cross sections were chosen in areas of significantly different PTn thickness and lithology. The southern cross section was located near the southeastern margin of the potential repository site. In this cross section, the PTn unit has a total thickness of $23 \mathrm{~m}$, including a thin section of nonwelded Yucca Mountain Tuff, and is overlain by a thick section of densely welded Tiva Canyon Tuff (fig. 47 and table 2). The northern cross section was located near the northern margin of the potential repository site. This cross section has a total PTn unit thickness of $77 \mathrm{~m}$, including welded Yucca Mountain Tuff and a thick section of nonwelded Pah Canyon Tuff, and is overlain by a comparatively thin section of densely welded Tiva Canyon Tuff (fig. 48 and table 2).

The preliminary model simulations show that the numerical representation of the PTn units influences the direction of water movement. Lateral flow in the southern cross section (fig. 47) is established within the densely welded Tiva Canyon Tuff and in the nonwelded pre-Pah Canyon Tuff bedded tuffs. Lateral flow in the northern cross section (fig. 48) is established within the densely welded Tiva Canyon Tuff, within the nonwelded Pah Canyon Tuff, and the lower nonwelded zone of the Yucca Mountain Tuff at high infiltration. 

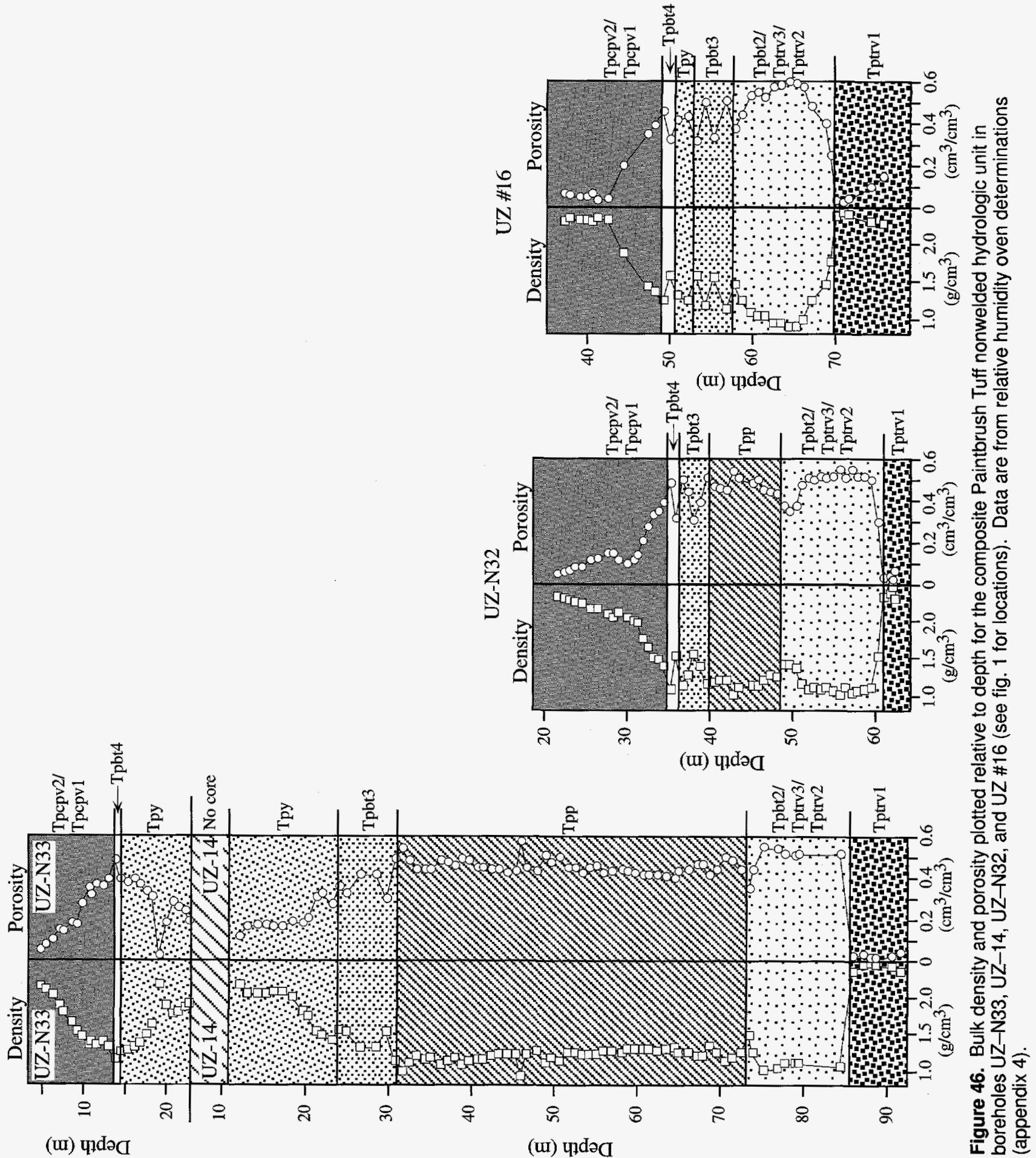

(uI) प1dəव

(a) प1dəC

(ui) प1dəव

需

돈

产

․ㅠ 

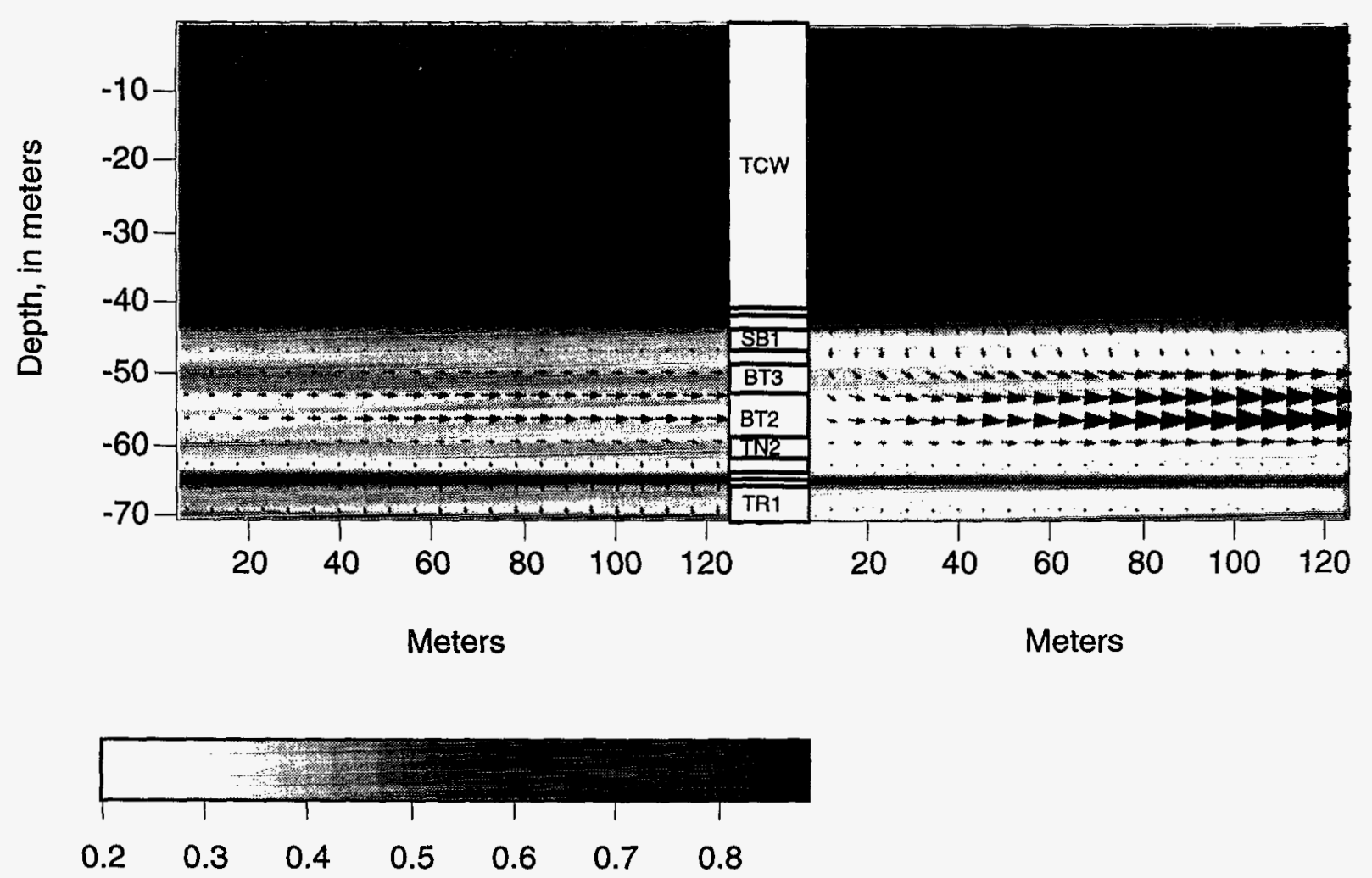

\section{Saturation}

Figure 47. Results of two-dimensional flow models between boreholes UZ-N53 and UZ\#16 (fig. 1) representing the lithology and physical properties of the Tiva Canyon Tuff, Paintbrush Tuff nonwelded units, and upper Topopah Spring Tuff. Infiltration was set at 0.1 millimeter per year in the model shown on left and at 1.0 millimeter per year in the model shown on the right. Models were computed using the TOUGH finite-difference code (Pruess, 1987) with parameters listed in table 2. Arrows represent relative flux direction and magnitude. Gray scale depicts saturation.

Within these model simulations, unit thickness appears to have a large influence on lateral water transmission (figs. 47 and 48). Lateral flow within the densely welded Tiva Canyon Tuff (model unit TCW) may be a function of the increased conductivity used to simulate the contribution of fracture permeability and to initiate flow in the model (see table 2 and section on study methods). In addition, it is likely that the gradual transition in properties of the base of the Tiva Canyon Tuff is misrepresented as an abrupt change in the properties. Nevertheless, the model results suggest that, at low fluxes, lateral flow is preferentially established where the densely welded Tiva Canyon Tuff is thick. Moreover, figure 48 illustrates that thick sections of nonwelded Pah Canyon Tuff (model unit PCl) divert water laterally despite having a lower permeability than the underlying bedded tuffs (table 2 ).
Figures 47 and 48 show that high saturations characterize the densely welded Tiva Canyon Tuff and the Topopah Spring Tuff crystal-rich vitrophyre, which have extremely low porosity and storage capacity. In contrast, the PTn units have saturations that are lower by a factor of only 2 , but porosities that are typically greater by a factor of 5 (table 2 ). As shown on figures 47 and 48, saturation of the PTn unit is not influenced by the total thickness of PTn material, despite a significant change in storage capacity between the two locations. Moreover, saturation is virtually unaffected by infiltration rate. In contrast with the densely welded Tiva Canyon Tuff, the PTn units in these simulations so readily divert water laterally downgradient that increases in saturation do not occur over any of the scenarios investigated. If, however, the 


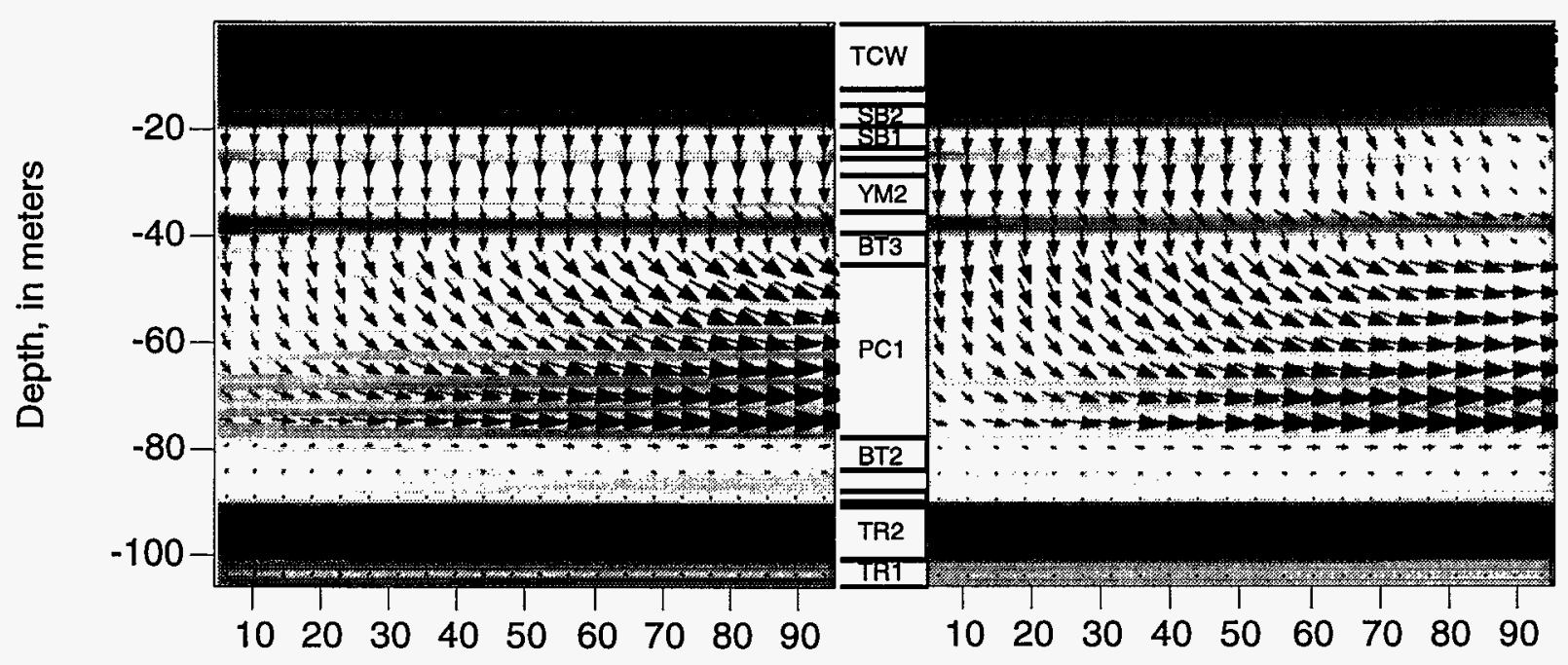

Meters

Meters

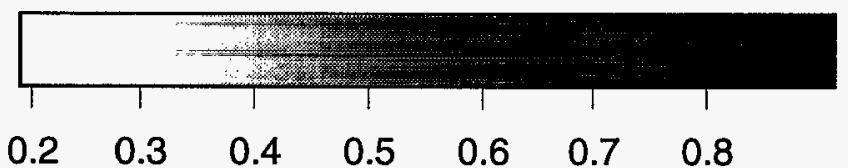

\section{Saturation}

Figure 48. Results of two-dimensional flow models between boreholes UZ-14 and SD-9 (fig. 1) representing the lithology and physical properties of the Tiva Canyon Tuff, Paintbrush Tuff nonwelded units, and upper Topopah Spring Tuff. Infiltration was set at 0.1 millimeter per year in the model shown on left and at 1.0 millimeter per year in the model shown on the right. Models were computed using the TOUGH finite-difference code (Pruess, 1987) with parameters listed in table 2. Arrows represent relative flux direction and magnitude. Gray scale depicts saturation.

numerical representation of the unit boundaries is oversimplified to a point that, in reality, lateral diversion does not occur, then the storage capacity of the thicker PTn can obviously accommodate large volumes of infiltrated water.

Two potentially significant model results require further analysis. Figure 47 shows that high surface flux produces a greater downward percolation through the densely welded Tiva Canyon Tuff than low surface flux. This leads to increased saturation at the top of the underlying moderately welded, crystal-poor vitric zone. High saturation most likely is produced by the lower fracture density assumed for the moderately welded zone in these models. Figures 47 and 48 illustrate that intervals underlying zones of lateral flow within the PTn unit (beneath model unit BT2 in fig. 47 and beneath model unit $\mathrm{PC} 1$ in fig. 48 ) have notably low saturation and flux. Although this simply may be an artifact of model properties, it could indicate that saturations needed to initiate fracture flow are not achieved at the top of the Topopah Spring Tuff crystalrich vitrophyre.

These preliminary results illustrate the importance of coupling lithologic and hydrologic studies. In addition, they emphasize that future model simulations should divide the PTn unit into several hydrologic subunits that include a gradual rather than abrupt transition through the low-permeability base of the Tiva Canyon Tuff (lithologic units Tpcpv2 and pv1), moderately welded Yucca Mountain Tuff (areally restricted to the northern part of the study area), thick sections of nonwelded Pah Canyon Tuff (also areally restricted to the northern part of the study area), and nonwelded, bedded tuff layers (lithologic units Tpbt4, Tpbt3, Tpbt2, 
and Tpp and Tpy where thin). The hydrologic effects of the thick nonwelded pyroclastic-flow deposits of unit Tpbt3E and of welded Pah Canyon Tuff, both of which occur in the northern part of the study area, were not evaluated in this study. These model simulations demonstrate that lateral variations in unit thickness and continuity clearly play a large role in fostering lateral diversion of water through and above the PTn unit, if no lateral heterogeneities are considered in the linearity of the unit boundaries.

\section{AREAS FOR CONTINUED STUDY}

The stratigraphic framework outlined herein forms the basis for future numerical flow and transport models of the hydrologically significant PTn unit. This report illuminates several areas in which continued studies of the PTn unit would help to constrain important model parameters. As discussed above, significant variations in hydrologic properties are related to variations in welding, secondary crystallization, and alteration of the PTn deposits. Future studies need to address the location and character of the important and poorly constrained transitions between welded, devitrified tuff and nonwelded, vitric tuff that occur within the Pah Canyon and Yucca Mountain Formations. Both formations are exposed in the northern Yucca Mountain region and are potential areas of surface infiltration. Additional studies to characterize the types, abundances, and formation of alteration products (clays and zeolites) could lead to a better understanding of porosity and permeability variations and permit a first-order investigation of fluid flow through the deposits and along fractures. Finally, studies that relate lithostratigraphy to borehole geophysical logs would extend our understanding of the PTn unit to boreholes that were not cored.

\section{CONCLUSIONS}

Observations of the Paintbrush Tuff nonwelded (PTn) hydrologic unit in core from boreholes and measured sections at Yucca Mountain, Nevada, were used to define a sequence of lithostratigraphic units and to characterize vertical and lateral variations in welding, secondary crystallization, alteration, and depositional history. Many of the units are regionally extensive and can be observed from the Yucca Wash area in the north to borehole GU-3 in the south. Several PTn units have depositional features consistent with limited reworking of primary pyroclastic material and alteration that suggests the development of incipient paleosols. Marker horizons identified within the sequence were used to correlate PTn strata throughout the Yucca Mountain region. These correlations show that the PTn unit thins substantially southward and that changes in thickness are due primarily to thinning of the pyroclastic-flow deposits of the Yucca Mountain Tuff, Pah Canyon Tuff, and an unnamed pyroclasticflow deposit correlated to the eruptions of the Black Glass Canyon rhyolite by Broxton and others (1993). Importantly, the lithostratigraphic units and correlations defined herein permit straightforward correlation of the hydrologic properties of PTn units throughout the Yucca Mountain region.

Plots of PTn hydrologic properties as a function of depth show a vertical asymmetry at the upper and lower contacts that is created by differences in the nature of the welding process. These plots also show that post-Topopah Spring Tuff pumice-fall deposits and nonwelded Pah Canyon Tuff are the most porous deposits within the PTn unit. Although most PTn strata have hydrologic properties that do not exhibit significant lateral variability, the Yucca Mountain Tuff and, by analogy, the Pah Canyon Tuff, have abrupt changes in properties that can be related to their welding and secondary crystallization history.

The results of preliminary hydrologic flow model simulations show that the PTn units, as numerically represented, control the lateral flow of water in the Paintbrush Group. These results also suggest that unit thickness within the PTn has a strong influence on lateral diversion and that the ability of the PTn units to transmit water laterally may preclude high levels of saturation within them. Moreover, the preliminary results indicate that future models should divide the PTn unit into several hydrologic subunits and illustrate the importance of coupling lithologic and hydrologic studies. Continued studies of the PTn unit would help to constrain important model parameters that are a function of (1) the abrupt welding transitions in the base of the Tiva Canyon Tuff and in the Yucca Mountain and Pah Canyon Tuffs, and (2) the types and abundances of alteration minerals. While the promotion of lateral diversion required more detailed layering than typically used, it is noted that numerical simplification continues to neglect gradual property transit and heterogeneities in linear contacts, thus overestimating lateral diversion in the PTn. 


\section{REFERENCES CITED}

Brookfield, M.E., 1984, Eolian sands, in Walker, R.G., ed., Facies models: Geological Association of Canada, Geoscience Canada, reprint series 1, p. 91-104.

Broxton, D.E., Chipera, S.J., Byers, F.M., Jr., and Rautman, C.A., 1993, Geologic evaluation of six nonwelded tuff sites in the vicinity of Yucca Mountain, Nevada for a surface-based test facility for the Yucca Mountain Project: Los Alamos National Laboratory Report LA-12542-MS, 75 p.

Buesch, D.C., Nelson, J.E., Dickerson, R.P., Drake, R.M., Spengler, R.W., Geslin, J.K., Moyer, T.C., and San Juan, C.A., in press, Distribution of lithostratigraphic units within the central block of Yucca Mountain, Nevada - A three-dimensional computerbased model, version YMP.R2.0: U.S. Geological Survey Open-File Report 95-124.

Buesch, D.C., Spengler, R.W., Moyer, T.C., and Geslin, J. K., 1996, Proposed stratigraphic nomenclature and macroscopic identification of lithostratigraphic units of the Paintbrush Group exposed at Yucca Mountain, Nevada: U.S. Geological Survey Open-File Report 94-469, 46 p.

Bush, D.C., and Jenkins, R.E., 1970, Proper hydration of clays for rock property determinations: Journal of Petroleum Technology, July, p. 800-804.

Byers, F.M., Jr., Carr, W.J., Orkild, P.P., Quinlivan, W.D., and Sargent, K.A., 1976, Volcanic suites and related cauldrons of Timber Mountain-Oasis Valley caldera complex, southern Nevada: U.S. Geological Survey Professional Paper 919, 70 p.

Caporuscio, F., Vaniman, D., Bish, D., Broxton, D., Arney, B., Heiken, G., Byers, F., Gooley, R., and Semarge, E., 1982, Petrologic studies of drill cores USW-G-2 and UE25b-1H, Yucca Mountain, Nevada: Los Alamos National Laboratory Report, LA-9255-MS, 111 p.

Cas, R.A.F., and Wright, J.V., 1987, Volcanic successions: London, Allen \& Unwin, $528 \mathrm{p}$.

Christiansen, R.L., and Lipman, P.W., 1965, Geologic map of the Topopah Spring NW Quadrangle, Nye County, Nevada: U.S. Geological Survey Map GQ-444, scale $1: 24,000,1$ sheet.

Christiansen, R.L., Lipman, P.W., Carr, W.J., Byers, F.M., Jr., and Orkild, P.P., 1977, Timber Mountain-Oasis Valley caldera complex of southern Nevada: Geological Society of America Bulletin, v. 88, p. 943-959.

Diehl, S.F., and Chornack, M.P., 1990, Stratigraphic correlation and petrography of the bedded tuffs, Yucca Mountain, Nye County, Nevada: U.S. Geological Survey Open-File Report 89-3, $152 \mathrm{p}$.
Flint, A.L., and Flint, L.E., 1990, Preliminary permeability and water-retention data for nonwelded and bedded tuff samples, Yucca Mountain area, Nye County, Nevada: U.S. Geological Survey Open-File Report 90-569, $57 \mathrm{p}$.

Flint, L.E., Flint, A.L., Rautman, C.A., and Istok, J.D., 1996, Physical and hydrologic properties of rock outcrop samples at Yucca Mountain, Nevada: U.S. Geological Survey Open-File Report 95-280, 54 p.

Fridrich, C.J., Orkild, P.P., Murray, Michele, Prince, J.R., Christiansen, R.L., Lipman, P.W., Carr, W.J., Quinlivan, W.D., and Scott, R.B., in press, Preliminary geologic map of the east of Beatty Mountain 7.5 minute quadrangle, Nye County, Nevada: U.S. Geological Survey Open-File Report 94-530.

Geological Society of America, 1991, Rock-color chart: Boulder, Colo., Geological Society of America.

Geslin, J.K., and Moyer, T.C., 1995, Summary of lithologic logging of new and existing boreholes, Yucca Mountain, Nevada, March 1994 to June 1994: U.S. Geological Survey Open-File Report 94-451, 16 p.

Geslin, J.K., Moyer, T.C., and Buesch, D.C., 1995, Summary of lithologic logging of new and existing boreholes at Yucca Mountain, Nevada, August 1993 to February 1994: U.S. Geological Survey Open-File Report $94-342,39 \mathrm{p}$.

Istok, J.D., Rautman, C.A., Flint, L.E., and Flint, A.L., 1994, Spatial variability in hydrologic properties of a volcanic tuff: Ground Water, v. 32, no. 5, p. 751-760.

Kollmorgen Instruments Corporation, 1992, Munsell soil color charts: New York, Kollmorgen Instruments Corporation.

Kwicklis, E.M., Flint, A.L., and Healey, R.W., 1993, Estimation of unsaturated zone liquid water flow at boreholes UZ \#4, UZ \#5, UZ \#7 and UZ \#13, Yucca Mountain, Nevada, from saturation and water potential profiles: Proceedings of Focus '93, Site Characterization and Model Validation, Sept. 26-29, Las Vegas, American Nuclear Society, La Grange Park, Ill.

Kwicklis, E.M., Flint, A.L., and Healey, R.W., 1994, Simulation of flow in the unsaturated zone beneath Pagany Wash, Yucca Mountain: High Level Radioactive Waste Management, Proceedings of the Fifth International Conference, American Nuclear Society, La Grange Park, I1l., v. 4, p. 2341-2351.

Lipman, P.W., and Christiansen, R.L., 1964, Zonal features of an ash-flow sheet in the Piapi Canyon Formation, southern Nevada: U.S. Geological Survey Professional Paper 501-B, p. B74-B78.

Lipman, P.W., and McKay, E.J., 1965, Geologic map of the Topopah Spring Southwest Quadrangle, Nye County, Nevada: U.S. Geological Survey Geologic Quadrangle Map GQ-439, scale 1:24000, 1 sheet. 
Maldonado, F., and Koether, S.L., 1983, Stratigraphy, structure, and some petrographic features of Tertiary volcanic rocks at the USW G-2 drill hole, Yucca Mountain, Nye County, Nevada: U.S. Geological Survey OpenFile Report 83-732, 83 p.

McKee, E.D., 1979, Sedimentary structures in dunes, in McKee, E.D., ed., A study of global sand seas: U.S. Geological Survey Professional Paper 1052, p. 83-134.

Montazer, Parviz, and Wilson, W.E., 1984, Conceptual hydrologic model of flow in the unsaturated zone, Yucca Mountain, Nevada: U.S. Geological Survey Water Resources Investigation Report 84-4345, 55 p.

Moyer, T.C., Geslin, J.K., and Buesch, D.C., 1995, Summary of lithologic logging of new and existing boreholes, Yucca Mountain, Nevada, July 1994 to November 1994: U.S. Geological Survey Open-File Report 95-102, 22 p.

Nelson, P.H., Muller, D.C., Schimschal, U., and Kibler, J.E., 1991, Geophysical logs and core measurements from forty boreholes at Yucca Mountain, Nevada: U.S. Geological Survey Geophysical Investigations Map GP-1001, 64 p., 10 sheets, scale 1:200.

Ortiz, T.S., Williams, R.L., Nimick, F.B., Whittet, B.C., and South, D.L., 1985, A three-dimensional model of reference thermal/mechanical and hydrological stratigraphy at Yucca Mountain, southern Nevada: Sandia National Laboratories Report SAND84-1076, Albuquerque, N. Mex.

Peters, R.R., Klavetter, E.A., Hall, I.F., Blair, S.C., Hellar, P.R., and Gee, G.W., 1984, Fracture and matrix hydrologic characteristics of tuffaceous materials from Yucca Mountain, Nye County, Nevada: Sandia National Laboratories Report SAND84-1471.

Peters, R.R., Klavetter, E.A., George, J.R., and Gauthier, J.H., 1987, Measuring and modeling water imbibition into tuff, in Evans, D.D., and Nicholson, R.H., eds., Flow and transport through unsaturated fractured rock: Geophysical Monograph 42, American Geophysical Union, Washington, D.C., p. 99-106.

Pruess, K., 1987, TOUGH user's guide: Lawrence Berkeley Laboratory Report LBL-20700, Berkeley, Calif., 78 p.

Pruess, K., 1991, TOUGH2-A general-purpose numerical simulator for multiphase fluid and heat flow: Lawrence Berkeley Laboratory Report LBL-29400, Berkeley, Calif., 102 p.

Rautman, C.A., and Flint, A.L., 1992, Deterministic geologic processes and stochastic modeling: High Level Radioactive Waste Management, Proceedings of the Third International Conference, American Nuclear Society, La Grange Park, Ill., p. 1617-1624.
Rautman, C.A., Flint, L.E., and Flint, A.L., 1995, Physical and hydrologic properties of outcrop samples from a nonwelded to welded tuff transition, Yucca Mountain, Nevada: U.S. Geological Survey, Water-Resources Investigations Report 95-4061, $28 \mathrm{p}$.

Rautman, C.A., Istok, J.D., Flint, A.L., Flint, L.E., and Chornack, M.P., 1993, Influence of deterministic geologic trends on spatial variability of hydrologic properties in volcanic tuff: High-Level Radioactive Waste Management, Proceedings of the Fourth International Conference, American Nuclear Society, Las Vegas, Nev., p. 921-929.

Rosenbaum, J.G., 1993, Magnetic grain-size variations through an ash-flow sheet-Influence on magnetic properties and implications for cooling history: Journal of Geophysical Research, v. 98, no. B7, p. 11715-11727.

Rowley, P.D., Kuntz, M.A., and MacLeod, N.S., 1981, Pyroclastic-flow deposits, in Lipman, P.W., and Mullineaux, D.R., eds., The 1980 eruption of Mt. St. Helens, Washington: U.S. Geological Survey Professional Paper 1250, p. 489-512.

Sawyer, D.A., Fleck, R.J., Lanphere, M.A., Warren, R.G., Broxton, D.E., and Hudson, M.R., 1994, Episodic caldera volcanism in the Miocene southwestern Nevada volcanic field: Revised stratigraphic framework, ${ }^{40} \mathrm{Ar} /{ }^{39} \mathrm{Ar}$ geochronology, and implications for magmatism and extension: Geological Society of America Bulletin, v. 106, p. 1304-1318.

Scott, R.B., and Bonk, J., 1984, Preliminary geologic map of Yucca Mountain, Nye County, Nevada, with geologic sections: U.S. Geological Survey Open-File Report 84 494, scale 1:12,000, 3 sheets, 9 p.

Scott, R.B., and Castellanos, M., 1984, Stratigraphic and structural relations of volcanic rocks in drill holes USW GU-3 and USW G-3, Yucca Mountain, Nye County, Nevada: U.S. Geological Survey OpenFile Report 84 491, 121 p.

Sheridan, M.F., 1970, Fumarolic mounds and ridges of the Bishop Tuff, California: Geological Society of America Bulletin, v. 81, p. 851-868.

Spengler, R.W., and Chornack, M.P., 1984, Stratigraphic and structural characteristics of volcanic rocks in core hole USW G-4, Yucca Mountain, Nye County, Nevada, with a section on geophysical logs by D.C. Muller and J.E. Kibler: U.S. Geological Survey Open-File Report 84-789, $77 \mathrm{p}$.

Spengler, R.W., Muller, D.C., and Livermore, R.B., 1979, Preliminary report on the geology and geophysics of drill hole UE25a-1, Yucca Mountain, Nevada Test Site: U.S. Geological Survey Open-File Report 79-1244, $43 \mathrm{p}$.

Spengler, R.W., and Rosenbaum, J.G., 1980, Preliminary interpretations of geologic results obtained from boreholes UE25a-4, -5, -6, and -7 , Yucca Mountain, Nevada Test Site: U.S. Geological Survey Open-File Report 80-929, $33 \mathrm{p}$. 
APPENDIXES 


\section{Appendix 1-Supplemental Lithologic Data for the Paintbrush Tuff Nonwelded Stratigraphic Units at Yucca Mountain, Nevada}

\section{Tiva Canyon Tuff, crystal-poor lower nonlithophysal zone, columnar subzone (Tpcplnc) - Moderately welded interval}

Lithology: Moderately welded, devitrified pyroclastic-flow deposit.

Matrix: Grayish orange-pink, grayish orange, or pale red (5YR7/1, 10YR7/4, 10R6/2) with light-brown to orange-brown (5YR6/6, 5YR6/8) devitrified shards.

Pumice clasts: Light to moderate brown (5YR5/4, 5YR3/4) and devitrified, or locally black (N1) and vitric.

Lithic clasts: Medium light-gray, moderate brown, or light brownish-gray (N6, 5YR5/4, 5YR6/1) devitrified volcanic rock.

Miscellaneous observations: The lowest part of the unit locally contains pale yellowish-orange (10YR6/6) argillic (?) alteration (for example, in core from boreholes UZ-N11 and UZ-N32). A reference example of this unit can be found in core from boreholes SD-9, UZ-N31, and UZ-N32.

\section{Tiva Canyon Tuff, crystal-poor vitric zone, moderately welded subzone (Tpcpv2)}

Lithology: Moderately welded, vitric pyroclastic-flow deposit.

Matrix: Shades of grayish orange and light brown (7.5YR6/4, 10YR6/4, 10YR7/4, 5YR6/4) or rarely shades of gray (N5 to N7). Shards are dominantly black or grayish orange to light brown (N1, 5YR5/6, 10YR6/4).

Pumice clasts: Grayish pink or grayish orange-pink (5R7/2, 5R8/2, 5YR7/2) and altered (argillic?), rarely white or grayish black $(\mathrm{N} 9, \mathrm{~N} 2)$ and vitric.

Lithic clasts: Medium gray, very light-gray or grayish-red (N5, N8, 5R4/2) devitrified volcanic rock.

Miscellaneous observations: Pale yellowish-orange (10YR6/6) argillic (?) alteration is common (for example, in core from boreholes UZ-N31 and NRG-7/7A). A reference example of this unit can be found in core from boreholes NRG-6, NRG-7/7A, SD-9, SD-12, UZ-N11, UZ-N31, and UZ-N32.

\section{Tiva Canyon Tuff, crystal-poor vitric zone, non- to partially welded subzone (Tpcpv1)}

Lithology: Non- to partially welded, vitric pyroclastic-flow deposit.

Matrix: Colors typically grade downward from grayish orange-pink, grayish orange, dark yellowish orange, or gray $(5 \mathrm{YR} 7 / 2,10 \mathrm{YR} 7 / 4,10 \mathrm{YR} 6 / 6,7.5 \mathrm{YR} 6 / 1, \mathrm{~N} 5-\mathrm{N} 6)$ to very light gray or pinkish gray (N8, 10YR8/1). Shards are dominantly black or light brown (N1, 10YR6/4) and are rarely colorless.

Pumice clasts: Clasts are dominantly altered (argillic?) and moderate orange-pink or grayish orange-pink (10R7/4, 5YR7/2), with subordinate vitric pinkish-gray, pale-red, or very pale-orange (5YR8/1, 7.5YR $8 / 3$, $2.5 \mathrm{YR} 7 / 2,10 \mathrm{R} 8 / 2$ ) clasts.

Lithic clasts: Common medium gray or very light-gray (N5, N8) and rare pale yellowish-brown or grayish-red (10YR6/2, 5R6/2) devitrified volcanic rock.

Miscellaneous observations: The base of the formation is typically marked by a pumice-rich ground layer. Matrix, pumice clasts, and lithic clasts in the ground layer have different proportions but are the same colors as in the overlying pyroclastic-flow deposit. In core from borehole NRG-7/7A, shard bubbles appear to be filled with a milky white amorphous mineral (opal?). A reference example of this unit can be found in core from boreholes NRG-6, NRG-7/7A, SD-9, SD-12, UZ-N11, and UZ-N32, and measured section PTn\#3.

88 Stratigraphic Relations and Hydrologic Properties of the Paintbrush Tuff Nonwelded (PTn) Hydrologic Unit, Yucca Mountain, Nevada 


\section{Pre-Tiva Canyon Tuff bedded tuffs (Tpbt4) - Unit B}

Lithology: Well-sorted pumiceous deposit.

Matrix: Moderate reddish orange (10R6/6) in top 10 to $50 \mathrm{~cm}$ of unit, matrix is not macroscopically visible below.

Pumice clasts: White to grayish orange-pink or moderate orange-pink (N9, 10R8/2, 5YR8/4).

Lithic clasts: Pale-red, medium light-gray, and rarely grayish-orange (10R6/2, N6, 10YR7/4) devitrified volcanic rock, and very light-gray and dusky brown (N8, 5YR2/2) glass.

Miscellaneous observations: In core from borehole SD-12, some pumice clasts are grayish yellow to moderate yellow $(5 Y 8 / 4,5 Y 7 / 6)$ and appear to be altered. The incipient paleosol at the top of unit B is locally absent; for example, in core from borehole UZ-N11. A reference example of this unit can be found in core from boreholes UZ-N11, SD-12, and NRG-7/7A.

\section{Pre-Tiva Canyon Tuff bedded tuffs (Tpbt4) - Unit A}

Lithology: Brown, nonwelded pyroclastic-flow deposit.

Matrix: Moderate yellowish brown (10YR5/4) with abundant dark yellowish-orange to black (10YR6/6, N1) glass shards.

Pumice clasts: White (N9).

Lithic clasts: Medium light-gray to pale-red (N6, 5R6/2) devitrified lava, black (N1) obsidian, some with flow foliation, and very light-gray (N8) perlitic glass.

Miscellaneous observations: Proportions of matrix, pumice clasts, and lithic clasts vary laterally. For example, unit A in core from borehole UZ \#16 is matrix rich ( 80 to 90 percent), with 5 to 15 percent lithic clasts and 3 to 5 percent pumice clasts, while in core from borehole NRG 6 , it contains up to 25 percent lithic clasts and up to 20 percent pumice clasts. A reference example of this unit can be found in core from boreholes NRG -6 and UZ \#16.

\section{Yucca Mountain Tuff (Tpy)}

Lithology: Non- to densely welded, vitric to devitrified, pyroclastic-flow deposit.

Matrix: Thick, vitric sections of the Yucca Mountain Tuff (boreholes NRG-7/7A, SD-9) typically exhibit a downward change in whole-rock color from shades of grayish orange-pink (5YR6/1, 5YR7/1, 5YR6/2, $5 \mathrm{YR} 7 / 2,10 \mathrm{R} 7 / 1)$ to shades of very light gray $(\mathrm{N} 7, \mathrm{~N} 8,10 \mathrm{YR} 8 / 1)$ to shades of pale red $(10 \mathrm{R} 6 / 2)$ or pale yellowish brown $(7.5 \mathrm{YR} 6 / 2,10 \mathrm{YR} 6 / 1,10 \mathrm{YR} 7 / 1,10 \mathrm{YR} 6 / 2,10 \mathrm{YR} 7 / 2)$ to shades of light gray to very light gray (N7, N8, 10YR8/1). Where thinner (boreholes NRG \#2B, UZ \#16, UZ-N53, UZ-N54, and UZ-N55), the vitric tuff has less variability and is found in colors that include very light gray, pale yellowish brown, very pale orange (10YR8/2), white (N9), or grayish orange (10YR7/3, 10YR7/4). Where the tuff varies downward from vitric to devitrified (boreholes UZ-N11, UZ-N33, UZ-N34), rock colors change from shades of grayish orange-pink to shades of grayish brown (5YR4/1, 5YR5/1, 10YR4/1, 10YR5/1) to shades of pale yellowish brown or light brownish gray $(5 \mathrm{YR} 5 / 1)$. Where the tuff varies downward from devitrified to vitric (borehole UZ-14), rock color changes from shades of grayish orange-pink to shades of light brown (5YR6/3, 5YR6/4) to shades of pale yellowish brown to shades of light gray to very light gray.

Translucent, vitreous, granular ash (boreholes NRG-7/7A and SD-9) occurs in shades of pinkish gray $(5 \mathrm{YR} 8 / 1,5 \mathrm{YR} 8 / 2)$ to very light gray $(\mathrm{N} 8,10 \mathrm{YR} 8 / 1)$ or white (N9). Cloudy or opaque granular ash that may be incipiently devitrified or altered occurs in shades of grayish orange-pink (5YR7/2, 5YR8/2), grayish pink (5YR8/1), very pale orange (10YR8/2), or medium light gray (N6). Argillically altered matrix is dark yellowish orange (10YR8/6), grayish orange (10YR8/4), or pale yellowish brown (10YR6/1). 
Glass shards grade downward from colorless to shades of grayish orange-pink (5YR7/1), very pale orange (10YR8/2), or pale yellowish brown (10YR5/1, 10YR6/1, 10YR5/2, 10YR6/2) to shades of moderate yellowish brown (10YR5/4, 10YR4/4), dark yellowish brown (10YR4/2), dusky yellowish brown (10YR2/2), or grayish black (N2) to shades of grayish orange-pink, very pale orange, or pale yellowish brown, to colorless. Shard colors depend partly on the thickness of the shard wall and partly on the viewing angle; it is common for colorless shards to appear medium dark gray (N4) on edge. Devitrified shards typically are light brown (5YR6/4, 5YR6/6, 5YR7/8).

Pumice clasts: Vesicular or frothy, vitric clasts with spherical to elongate vesicles are grayish black to medium gray (N2 to N5), dark, moderate, or light yellowish brown (10YR4/2, 10YR 5/4, or 10YR6/2), very pale orange (10YR8/2), or colorless. Silky, finely fibrous clasts, likely devitrified or altered, occur in shades of grayish orange (10YR7/4), moderate pink to moderate orange-pink (5R7/4 to 10R7/4), grayish orange-pink (10R8/2), or light to very light gray (N7 to N8). Pumice clasts that contain coarse vapor-phase crystals appear brownish gray to light brownish gray (5YR4/1 to $5 \mathrm{YR} 6 / 1)$ to pale red (5R6/2). Argillically altered pumice clasts appear pinkish gray to grayish pink (5YR8/1 to $5 \mathrm{R} 8 / 2)$.

Lithic clasts: Clasts of devitrified volcanic rock occur in shades of pale red (5R5/1 to 5R6/2, 5R7/2), medium to light gray (N5 to N7), and pale brown (5YR5/2) to grayish orange-pink (5YR7/2).

Miscellaneous observations: The core from most boreholes preserves evidence for reworking of the upper Tpy: (1) Discontinuous sandy partings of a few millimeters thickness and composed of broken glass shards occur to $0.6 \mathrm{~m}$ below the upper Tpy contact in UZ-N11 and to $0.3 \mathrm{~m}$ below the contact in UZ-N33. (2) Matrix ash in UZ-N33 is cloudy from the upper contact to about $14.7 \mathrm{~m}$. (3) Red-stained lithic clasts occur in the upper few centimeters of Tpy in borehole UZ-N11. (4) A discontinuous layer of comparatively coarse (5 mm diameter), angular, lithic clasts occurs below a bedding break at $0.05 \mathrm{~m}$ below the contact in borehole UZ-N33.

(5) The rock matrix is darker in the upper $0.6 \mathrm{~m}$ of borehole UZ-N11 than below (10YR6/2 versus N8) and in the upper few centimeters of Tpy in borehole SD-9 (5YR8/2 versus 5YR8/1). The rock matrix is light brown (5YR6/3, 5YR7/4) in the upper meter of borehole a\#6 (versus 10YR8/2 below). (6) A rounded, cobble-shaped mass of Tpbt4A material $[70 \mathrm{~mm}$ long by $>57 \mathrm{~mm}$ (core width)] occurs at $52.5 \mathrm{~m}$ in borehole UZ \#16 (contact is at $50.6 \mathrm{~m}$ ). The "cobble" has a matrix color of 7.5YR6/4, contains a few percent of bubble-textured glass shards (10YR5/4 glass), 1 to 2 percent feldspar phenocrysts, and 15 percent lithic clasts (1 to $3 \mathrm{~mm}$ ) that include colorless globule-textured glass, devitrified volcanic rock (5R4/2,5R6/2, 5YR7/2), and obsidian (N2). This material may represent a burrow infilled by material from above.

The lower 20 to $30 \mathrm{~mm}$ of Tpy is a coarse, clast-supported, lag deposit. The lag contains 20 to 30 percent of frothy to coarsely vesicular, vitric pumice clasts (colorless, 10YR6/2, 10YR7/2, 10YR6/6) that are typically 10 to $20 \mathrm{~mm} ; 20$ to 40 percent of lithic clasts (devitrified volcanic rock in shades of N6 to N7, 5R4/2 to 5R6/2 to 5YR6/2 and colorless, globule-textured glass) that are typically smaller than $10 \mathrm{~mm}$; blocky, cuspate glass shards that vary from N2 to $10 \mathrm{YR} 5 / 4$ to $10 \mathrm{YR} 7 / 2$; and less than 5 percent crystals of feldspar. Laminated surge and ground layers occur in lowest $0.5 \mathrm{~m}$ of the formation in core from borehole $\mathrm{G}-2$.

Reference stratigraphic intervals of non- to partially welded, vitric Tpy can be found in core from boreholes SD-9 and NRG-7/7A; the upper vitric to devitrified transition is well preserved in core from boreholes UZ-N11 and UZ-N33; and the lower devitrified to vitric transition is well preserved in core from borehole UZ-14.

\section{Pre-Yucca Mountain Tuff bedded tuffs (Tpbt3) - Unit G}

Lithology: Light-brown, poorly sorted, clast-supported fallout (?) deposit.

Matrix: Light brown (5YR6/4).

Pumice clasts: White (N9).

90 Stratigraphic Relations and Hydrologic Properties of the Paintbrush Tuff Nonwelded (PTn) Hydrologic Unit, Yucca Mountain, Nevada 
Lithic clasts: Dominant colorless to very light-gray (N8) glass (some perlitic), subordinate pale-red (5R6/2) devitrified volcanic rock, and rare dusky brown to black $(5 \mathrm{YR} 2 / 2, \mathrm{~N} 1)$ glass.

Miscellaneous observations: A reference example of this unit can be found in core from boreholes UZ-14, SD-9, and UZ \#16, and measured sections PTn\#2, PTn\#8, and PTn\#10.

\section{Pre-Yucca Mountain Tuff bedded tuffs (Tpbt3) - Unit F}

Lithology: Light-gray to tan fallout deposit.

Matrix: Unit does not contain macroscopically visible matrix.

Pumice clasts: White, grayish pink, and grayish orange (N9, 5R8/2, 10YR7/4).

Lithic clasts: Dominant colorless to very light-gray (N8) glass (some perlitic), subordinate moderate light-gray, pale-red, moderate red, and light-brown (N6, 5R6/2, 5R5/4, 5YR6/4) devitrified volcanic rock, and very rare black (N1) glass.

Miscellaneous observations: A reference example of this unit can be found in core from boreholes UZ-14, $\mathrm{UZ} \# 16, \mathrm{NRG}-7 / 7 \mathrm{~A}$, and NRG-6.

\section{Pre-Yucca Mountain Tuff bedded tuffs (Tpbt3) - Unit E}

Lithology: Nonwelded pyroclastic-flow deposits and laterally equivalent ash-rich fallout deposit.

Matrix: In the pyroclastic-flow deposit: white to grayish orange-pink (N9, 10R8/2). In the fallout deposit: moderate orange-pink (5YR8/4).

Pumice clasts: In the pyroclastic-flow deposit: white (N9) and very rare moderate reddish orange (10R6/6). In the fallout deposit: moderate orange-pink to grayish orange-pink (5YR8/4, 10YR8/2).

Lithic clasts: In the pyroclastic-flow deposit: dominant very light-gray (N8) to colorless perlitic glass, subordinate pale yellowish-brown, pale-red, moderate brown, and medium light-gray (10YR6/2, 10R6/2, 5YR4/4, N6-N7) devitrified volcanic rock, and rare black (N1) glass. In the fallout deposit: dominant colorless to very light-gray (N8) perlitic glass, subordinate pale-red (5R6/2,10R6/2) devitrified volcanic rock, and black (N1) glass.

Miscellaneous observations: A reference example of the pyroclastic-flow deposits in this unit can be found in core from boreholes G-2 and UZ-14 and measured section PTn\#1; a reference example of the ash-rich fallout deposit in this unit can be found in core from borehole $\mathrm{NRG}-6$.

\section{Pre-Yucca Mountain Tuff bedded tuffs (Tpbt3) - Unit D}

Lithology: Light-gray, coarse, moderately sorted fallout deposit.

Matrix: Unit does not contain macroscopically visible matrix.

Pumice clasts: White, pale yellowish orange, and light brown (N9, 10YR8/6, 5YR6/4).

Lithic clasts: Dominantly moderate light-gray, pale brown, pale-red, and moderate reddish-brown (N6, 5YR5/2, $5 \mathrm{R} 6 / 2,10 \mathrm{R} 4 / 6)$ devitrified volcanic rock, subordinate colorless to very light-gray (N8) perlitic glass, rare black (N1) glass, and grayish-orange-pink (5YR7/2) porphyritic devitrified volcanic rock.

Miscellaneous observations: Lithic clasts are typically altered or "rusted," with dusky red to moderate reddishorange $(5 \mathrm{R} 3 / 4,10 \mathrm{R} 4 / 6)$ alteration. The alteration of lithic clasts appears to be confined to evenly spaced horizons along bedding planes. A reference example of this unit can be found in core from boreholes NRG-7/7A and UZ \#16. 


\section{Pre-Yucca Mountain Tuff bedded tuffs (Tpbt3) - Unit C}

Lithology: Tan, moderately sorted, pumiceous fallout deposit.

Matrix: Pale yellowish brown to dark yellowish orange (10YR6/2, 10YR6/6).

Pumice clasts: White (N9) with a light-brown (5YR6/4) coating.

Lithic clasts: Pale red, moderate red, pale-brown to moderate brown, and moderate light-gray (5R6/2, 5R5/4, 5YR5/2, 5YR4/4, N6) devitrified volcanic rock, colorless to very light-gray (N8) glass (some perlitic), and rare black (N1) glass.

Miscellaneous observations: A reference example of this unit can be found in core from boreholes UZ \#16, SD-12, and UZ-N37.

\section{Pre-Yucca Mountain Tuff bedded tuffs (Tpbt3) - Unit B}

Lithology: Poorly sorted, clast-supported to matrix-supported, weathered or reworked fallout deposit.

Matrix: Typically moderate reddish orange to grayish orange-pink (10R6/6, 5YR7/4), rarely light brown (5YR6/4).

Pumice clasts: White to grayish orange-pink (N9, 10R8/2).

Lithic clasts: Pale-red, moderate light-gray, and moderate red (5R6/2, N6, 5R5/4) devitrified volcanic rock, and subordinate colorless to very light-gray (N8) perlitic glass.

Miscellaneous observations: A reference example of this unit can be found in core from boreholes SD-12 and NRG-7/7A.

\section{Pre-Yucca Mountain Tuff bedded tuffs (Tpbt3) - Unit A}

Lithology: Gray, coarse-grained, pumiceous fallout deposit.

Matrix: Matrix is not macroscopically visible in this unit, except where the upper contact of the unit is gradational.

Pumice clasts: Very light gray to moderate orange-pink (N8, 5YR8/4); some pumice clasts have pale yellowishorange (10YR8/6) rims.

Lithic clasts: Pale-red, moderate light-gray, and grayish-red (5R6/2, N6, 10R4/2) devitrified volcanic rock, rare colorless to very light-gray (N8) perlitic glass, rare black and light-red (N1, 5R6/6) glass.

Miscellaneous observations: A reference example of this unit can be found in core from boreholes NRG-6 and NRG-7/7A.

\section{Pah Canyon Tuff (Tpp)}

Lithology: Non- to moderately welded, vitric to locally altered or devitrified, pyroclastic-flow deposit.

Matrix: The matrix colors of vitric tuff typically vary downward from shades of grayish pink to grayish orangepink $(5 R 7 / 2,5 Y R 7 / 2)$ to shades of moderate orange-pink or light brown $(10 \mathrm{R} 7 / 4,2.5 \mathrm{YR} 7 / 2,2.5 \mathrm{YR} 7 / 3$, 5 YR6/3, 5 YR7/4, 5YR8/3) to shades of yellowish brown to grayish orange (10YR7/1, 10YR7/3, 10YR6/1, $10 \mathrm{YR} 6 / 2)$ to shades of grayish pink, very pale orange, or white $(5 \mathrm{YR} 8 / 1,10 \mathrm{YR} 8 / 1, \mathrm{~N} 9)$. Glass shards are most commonly colorless, but may be pale to dark yellowish brown (10YR6/2 to 10YR3/1) or dark gray to grayish black (N3, N2). Altered shards are light brown (5YR6/6).

92 Stratigraphic Relations and Hydrologic Properties of the Paintbrush Tuff Nonwelded (PTn) Hydrologic Unit, Yucca Mountain, Nevada 
The matrix colors of altered tuff are variable and include shades of pinkish gray (5R8/2), pale orange-pink (7.5YR8/3), moderate orange-pink (10R8/4), very pale orange (10YR8/2), pale greenish yellow (5Y8/1), and grayish yellow (5Y7/4). Remnant shard textures are variably, but generally poorly, preserved, the rock has a "chalky" texture, and millimeter-sized spots of $\mathrm{MnO}_{\mathrm{x}}$ locally are common.

The matrix colors of devitrified tuff vary downward from shades of light brown (7.5YR6/4) to moderate brown (7.5YR4/4) to grayish orange-pink (5YR7/2, 5YR7/1, 5YR8/2, 5YR8/3).

Pumice clasts: Type I pumice clasts, where vitric, are typically light to very light gray (N7 to N8), but may grade to medium light gray (N6) or shades of very pale orange (10YR8/1, 10YR8/2) or grayish orange-pink (5YR8/2). Frothy, vitric type II pumice clasts vary from light pinkish brown (2.5YR6/3) to dark yellowish orange (10YR6/6); silky type II clasts are typically shades of yellowish orange (10YR7/6) to pale grayish orange (10YR8/4). Vitric type II-cv clasts have colors that vary from dark gray (N3) to dusky yellowish brown (10YR3/1) to pale yellowish brown (10YR6/1) to dark yellowish orange (10YR6/6).

Altered pumice clasts may appear grayish orange-pink (5YR7/2), pinkish gray (5YR8/1), moderate orangepink (5YR8/4, 10YR8/4), very pale orange (10YR8/2), or very light gray to white (N8 to N9).

Devitrified pumice clasts occur in shades of pale, moderate, or light brown (5YR5/2, 5 YR4/4, 5YR6/4), or grayish orange-pink (5YR7/2). Vapor-phase altered pumice clasts are pinkish gray to grayish pink (5YR8/1, $5 \mathrm{R} 8 / 2)$.

Lithic clasts: Clasts of devitrified volcanic rock occur in shades of grayish red to pale red (5R4/2 to 5R6/2, 5R6/1), medium to light gray (N5 to N7), or moderate to light brown (5YR4/4 to 5YR6/4). Clasts of glassy volcanic rock occur in shades of grayish black to medium dark gray (N2 to N4) or moderate reddish brown $(10 \mathrm{R} 4 / 6)$. Where the tuff is altered, moderate reddish-brown $(10 \mathrm{R} 4 / 6)$ glassy lithic clasts are replaced by altered clasts of similar color.

Miscellaneous observations: Mean pumice shape ratios for welded Pah Canyon Tuff in borehole G-2 are given in table A-1. The unit appears as a single, reversely graded bed in borehole SD-12. The lowest several feet of the formation are comparatively fine grained in borehole UZ-N32. The upper $0.3 \mathrm{~m}$ of the deposit in boreholes UZ-N31 and G-2 may be reworked. The formation grades downward from altered to vitric in boreholes a\#1 and a\#5 and from vitric to altered in borehole NRG \#4. The formation is altered throughout boreholes NRG \#2B and a\#7. Abundant, euhedral blocky crystals occur throughout the matrix in borehole G-2 from 188.4- to 196.9-m depth. High-angle to subvertical fractures are observed in boreholes NRG \#4 (136.8 to $137 \mathrm{~m}$ ) and G-2 (188.4 to $196.9 \mathrm{~m}$ ). A clast-supported, crystal-lithic-pumice-rich fall horizon occurs at $213.5 \mathrm{~m}$ (as measured upward from the core run marker at $215.2 \mathrm{~m}$ ) in borehole $\mathrm{G}-2$. Reference stratigraphic sections of nonwelded, vitric Pah Canyon Tuff can be found in core from boreholes UZ-14 and NRG-7/7A; for welded, devitrified Pah Canyon Tuff in core from borehole G-2, and for nonwelded, vitric to altered Pah Canyon Tuff in core from borehole NRG \#4.

\section{Pre-Pah Canyon Tuff bedded tuffs (Tpbt2), unit D}

Lithology: Matrix-supported, possibly reworked deposit.

Matrix: Pale yellowish brown (10YR7/2) that varies to light brown (5YR6/4); may be pale brown (5YR6/2) where locally altered.

Pumice clasts: Two types occur: (1) Light-gray to very light-gray (N7 to N8) clasts are vitric [grayish yellow (5Y8/4) where altered]. (2) Moderate orange-pink (10R7/4) clasts (typically this coloration occurs as a rind enclosing a lighter interior) are slightly altered; they are light brown (5YR5/6) where strongly altered. These pumice clasts are more abundant where the substrate is argillically altered, and they tend to become less abundant stratigraphically upward. 
Table A-1. Mean pumice shape ratios in the Pah Canyon Tuff-borehole USW G-2

\begin{tabular}{|c|c|c|c|}
\hline $\begin{array}{l}\text { Depth } \\
\text { range }\end{array}$ & $\begin{array}{c}\text { Average } \\
\text { ratio }\end{array}$ & $\begin{array}{l}\text { Standard } \\
\text { deviation }\end{array}$ & Number \\
\hline $153.5-153.9 \mathrm{~m}$ & 2.31 & 0.94 & 10 \\
\hline $155.1-155.3$ & 1.84 & 0.74 & 10 \\
\hline $156.7-156.8$ & 2.03 & 0.89 & 9 \\
\hline $158.3-158.6$ & 2.03 & 0.59 & 9 \\
\hline $159.8-160.0$ & 2.08 & 0.89 & 10 \\
\hline $161.5-161.8$ & 2.65 & 1.79 & 13 \\
\hline $163.1-163.4$ & 1.77 & 0.65 & 13 \\
\hline $164.6-164.8$ & 1.76 & 0.45 & 10 \\
\hline $167.0-167.3$ & 2.72 & 0.97 & 10 \\
\hline $169.2-169.5$ & 2.45 & 1.52 & 10 \\
\hline $170.7-171.0$ & 2.37 & 0.93 & 11 \\
\hline $172.5-172.8$ & 2.31 & 0.64 & 11 \\
\hline $174.0-174.3$ & 4.29 & 2.00 & 11 \\
\hline $175.6-175.9$ & 3.34 & 2.39 & 11 \\
\hline $176.8-177.1$ & 4.24 & 2.78 & 11 \\
\hline $178.3-178.6$ & 4.62 & 1.55 & 10 \\
\hline $179.9-180.2$ & 3.97 & 2.58 & 10 \\
\hline $181.7-182.0$ & 3.50 & 1.44 & 12 \\
\hline $183.1-183.3$ & 2.71 & 2.31 & 11 \\
\hline $184.4-184.6$ & 2.87 & 0.69 & 12 \\
\hline $186.0-186.2$ & 4.37 & 2.58 & 12 \\
\hline $187.4-187.7$ & 3.01 & 1.03 & 11 \\
\hline $189.0-189.3$ & 4.40 & 1.42 & 10 \\
\hline $190.5-190.8$ & 2.76 & 1.56 & 10 \\
\hline $192.0-192.3$ & 3.22 & 1.39 & 11 \\
\hline $193.5-193.8$ & 3.05 & 1.12 & 11 \\
\hline $195.1-195.4$ & 4.28 & 2.07 & 10 \\
\hline $196.3-196.5$ & 5.15 & 2.42 & 10 \\
\hline $198.1-198.4$ & 3.81 & 1.98 & 10 \\
\hline $199.6-199.9$ & 3.90 & 0.93 & 10 \\
\hline $201.2-201.5$ & 2.71 & 1.57 & 10 \\
\hline $202.7-203.0$ & 4.19 & 1.94 & 10 \\
\hline $204.1-204.3$ & 2.67 & 1.35 & 10 \\
\hline $205.4-205.7$ & 4.88 & 2.06 & 10 \\
\hline $207.0-207.3$ & 4.38 & 1.05 & 8 \\
\hline $208.6-208.9$ & 2.90 & 1.03 & 10 \\
\hline $210.3-210.6$ & 2.36 & 0.57 & 10 \\
\hline $211.9-212.1$ & 2.32 & 1.12 & 11 \\
\hline $213.3-213.5$ & 2.17 & 0.78 & 11 \\
\hline $214.9-215.2$ & 1.76 & 0.52 & 7 \\
\hline $216.6-216.7$ & 1.94 & 0.43 & 10 \\
\hline $218.4-218.7$ & 2.23 & 1.11 & 10 \\
\hline $220.1-200.4$ & 2.34 & 0.98 & 10 \\
\hline $222.4-222.7$ & 2.04 & 0.82 & 7 \\
\hline
\end{tabular}


Lithic clasts: Clasts include grayish-black (N2), feldspar-phyric glass and devitrified volcanic rock in shades of pale red to pale brown (10R6/2 to 5 YR6/2).

Miscellaneous observations: A thin (about $0.1 \mathrm{~m}$ ), clast-supported deposit of light-gray (N7 to N8) pumice is preserved within unit $D$ in boreholes NRG-6, UZ-N31, a\#1, and G-2. This deposit, which occurs approximately $0.5 \mathrm{~m}$ below the upper contact of unit $\mathrm{D}$, has upper and lower contacts that are gradational over less than $5 \mathrm{~cm}$, suggestive of reworking. In borehole $\mathrm{GU}-3$, unit $\mathrm{D}$ is thicker than normal, and the lower part is an immature, coarse, tuffaceous sandstone that is moderately sorted. The upper part of unit D is finer grained, more poorly sorted, and richer in biotite than the lower part of the deposit; the lower part of unit D contains minor pyroxene. Reference stratigraphic intervals for unit D can be found in boreholes UZ-N31, UZ \#16, SD-9, and UZ-N37.

\section{Pre-Pah Canyon Tuff bedded tuffs (Tpbt2), unit C}

Lithology: Variably altered, nonwelded, clast-supported, moderately sorted pumice-fall deposit.

Matrix: Matrix ash typically occurs in shades of very pale orange to white (10YR8/1, 10YR8/2 to N9), but locally may be grayish orange-pink to very pale orange ( 7.5 YR7/3 to $10 \mathrm{YR} 7 / 2)$. Hydrothermal (?) alteration may occur along clast margins or within the matrix, imparting a moderate reddish-brown (10R4/6) stain. Top of the unit locally is argillically altered with variable colors that include moderate red, moderate pink or moderate orange-pink, grayish pink or grayish orange-pink, and white (5R5/4, 5R7/4 to $10 \mathrm{R} 7 / 4,5 \mathrm{R} 8 / 2$ to $10 \mathrm{R} 8 / 2$, N9).

Pumice clasts: Shades of very pale orange to white (10YR8/1, 10YR8/2 to N9) where vitric and unaltered, but may be white, yellowish gray, grayish yellow, very pale orange, or light brown (N9, 2.5Y8/2, 5Y8/4, 10YR8/2, 5YR6/4 to 5YR6/6) where altered.

Lithic clasts: Clast types include grayish-black (N2), biotite- and feldspar-bearing glass [commonly with moderate yellowish-brown (5YR5/6) alteration]; devitrified volcanic rock in shades of moderate red to light red (5R5/4 to 5R6/6) and pale red to grayish pink or light gray (5R6/2 to 5R8/2 or N7); glassy, biotite- and feldspar-bearing tuff that is moderate yellowish brown (5YR5/6) when welded but moderate reddish orange to light red (10R6/6 to 5R6/6) when nonwelded; grayish-orange-pink (5YR7/1), feldspar- and biotite-bearing, hydrated glass; and light-gray (N7), finely crystalline (cognate?) subvolcanic rock. Clast types are generally similar throughout, although clasts of moderate red (5R5/4) volcanic rock may be more abundant below ash layer 2.

Miscellaneous observations: Crystals compose from 5 to 7 percent of the rock above ash layer 2 and from 7 to 10 percent below ash layer 2. Estimated biotite:pyroxene ratios are from 5:1 to 7:1 above ash layer 2 and from 5:1 to 10:1 below. Reference stratigraphic intervals for unit C can be found in boreholes UZ-N53, UZ-14, SD-9, and NRG-6.

\section{Pre-Pah Canyon Tuff bedded tuffs (Tpbt2), ash layer 2}

Lithology: Pinkish ash overlain by a thin, lithic-rich fallout.

Matrix: Basal ash is grayish pink to grayish orange-pink (5R7/2 to $5 \mathrm{YR} 7 / 2)$.

Pumice clasts: White to very pale orange (N9 to 10YR8/1).

Lithic clasts: Moderate red (5R5/4), devitrified volcanic rock, light-brown (5YR5/6), feldspar-phyric glass, and grayish-black (N2) glass.

Miscellaneous observations: Reference stratigraphic intervals can be found in core from boreholes UZ-14 and NRG-6. 
Pre-Pah Canyon Tuff bedded tuffs (Tpbt2), unit B [includes the upper part of the Topopah Spring Tuff crystal-rich vitric zone, non- to partially welded subzone (Tptrv3) as defined by Buesch, Spengler, and others, 1996]

Lithology: Altered, nonwelded, clast-supported, moderately sorted pumice-fall deposit.

Matrix: This unit contains little to no matrix.

Pumice clasts: Altered clasts are light brown (5YR5/6, 7.5YR5/8). Vitric to slightly altered clasts are very light gray to white (N8 to N9), locally grayish pink (5R8/2).

Lithic clasts: Clasts of feldspar- and biotite-bearing glass are either grayish black (N2) with light-brown (5YR5/6) alteration or light brown (5YR5/6); colorless glass appears aphyric. Clasts of devitrified volcanic rock are pale to moderate red (5R6/2 to 5R5/4), grayish red to medium light gray (10R5/1 to N6), or pale brown (5YR5/2). Other clasts include white (N9), sugary, hypabyssal (?) rock; dark yellowish-brown (10YR4/1), feldspar- and biotite-bearing cognate (?) inclusions; and moderate pink (5R7/4), feldspar- and biotite-bearing tuff.

Miscellaneous observations: Indistinct pumice-clast margins create the appearance of matrix support; the deposit contains very light-gray pumice clasts enclosed by light-brown material. An abrupt decrease in the amount of glassy lithic clasts occurs in the lower part of the deposit. Core from boreholes SD-9 and UZ-N37 can be used as reference stratigraphic intervals for unit $B$.

\section{Pre-Pah Canyon Tuff bedded tuffs (Tpbt2), ash layer 1 (top of the Topopah Spring Tuff as defined by Buesch, Spengler, and others, 1996)}

Lithology: Pinkish ash overlain by a thin, lithic-rich fallout.

Matrix: Basal ash is light red, moderate pink, or moderate orange-pink (5R6/6, 5R7/4, 10R7/4).

Pumice clasts: Vitric pumice clasts are white (N9).

Lithic clasts: Devitrified volcanic rock occurs in shades of grayish red, pale red, or medium light gray (5R4/2, 5R6/2, N6).

Miscellaneous observations: In borehole G-2, ash layer 1 consists of 2-cm-thick ash beds that are separated by about $3 \mathrm{~cm}$ of coarser, clast-supported fallout. Core from boreholes SD-9 and NRG-6 can be used as reference stratigraphic intervals for ash layer 1.

Pre-Pah Canyon Tuff bedded tuffs (Tpbt2), unit A lincludes the Topopah Spring Tuff crystal-rich vitric zone, non- to partially welded subzone (Tptrv3) and moderately welded subzone (Tptrv2) as defined by Buesch, Spengler, and others, 1996]

Lithology: Variably welded, clast-supported, moderately sorted pumiceous fallout.

Matrix: This unit contains little to no matrix ash.

Pumice clasts: Vitric clasts are medium light gray (N6) and moderate brown (5YR4/4).

Lithic clasts: Clasts of devitrified, feldspar-and biotite-bearing volcanic rocks occur in shades of medium light gray (N6), grayish red (10R5/1), and moderate to pale red (5R5/4 to 5R6/2). Clasts of colorless glass are very rare.

Miscellaneous observations: Large pore spaces separate clasts in the upper part of the unit. Intergranular porosity decreases downward so that most porosity is eliminated in the lowest $15 \mathrm{~cm}$ of the deposit where pumice clasts are deformed and define foliation. Unit A may be compositionally zoned as suggested by changes in phenocryst amount and type downward. Brown pumice clasts predominate light-gray clasts in the upper $50 \mathrm{~cm}$ to $1 \mathrm{~m}$ of the deposit, but are subordinate to light-gray clasts in the lower part of the unit. Brown pumice clasts have phenocrysts of feldspar, minor biotite, and pyroxene, whereas light-gray clasts have sparse phenocrysts of feldspar in the upper part of the deposit. At lower stratigraphic levels, both types of pumice have only feldspar phenocrysts. Opal (?) locally forms a very thin coating on fragments within the upper part of the deposit, which imparts a pale-red (10R6/1) color to pumice, lithic clasts, and crystals. Core from borehole UZ-N32 and NRG-6 can be used as reference stratigraphic intervals for unit A. 


\section{Appendix 2-Measured Stratigraphic Sections of the Paintbrush Tuff Nonwelded Hydrologic Unit at Yucca Mountain, Nevada}

\section{Measured stratigraphic section on Isolation Ridge (section PTn\#1)}

Location description: Section begins on the northern nose of the ridge, north of a near-vertical fault trending 340. Measurement began in the Pah Canyon Tuff, in a gully at the base of the ridge, and continued to the base of the Tiva Canyon Tuff. Measurement was then offset to the south along the basal Tiva Canyon Tuff contact, trending up the southwest side of the ridge.

Approximate starting location: N777540 E563660 (Nevada state coordinate system), elevation 4,445 ft. Approximate finishing location: N777450 E564714 (Nevada state coordinate system), elevation $4,750 \mathrm{ft}$.

Strike and dip of bedding: 38 (N38E), 6 on bedded tuff $3.1 \mathrm{~m}$ above the Pah Canyon Tuff. 37 (N37E), 7 on bedded tuff $4.6 \mathrm{~m}$ below Yucca Mountain Tuff. 20 (N20E), 9 on basal contact of the Tiva Canyon Tuff.

Line of section: 128 below the Tiva Canyon Tuff, with multiple small southwest offsets to stay on nose of ridge. 89 on the southwest side of the ridge above the basal Tiva Canyon Tuff contact. Average dip in the line of section is 7 .

Stratigraphic

Thickness

(meters)

Top of section

Tiva Canyon Tuff (Tpe)

Crustal-poor lower nonlithophysal zone (Tpcpln)

Columnar subzone (Tpcplnc)

8.0 Pyroclastic-flow deposit, light pinkish tan to brownish pink upward, moderately welded to densely welded upward. Pumice clasts are grayish red-brown, vapor-phase altered, and corroded (mostly $<30 \mathrm{~mm}$ ). Pumice textures are less visible upward. Some shard textures visible in lower $2.4 \mathrm{~m}$. Well-developed vertical cooling joints. Upper contact is irregular and gradational over $\sim 1 \mathrm{~m}$.

Crystal-poor vitric zone (Tpcpv)

Moderately welded subzone (Tpcpv2)

0.5 Pyroclastic-flow deposit, tan with black glass shards, moderately welded. Pumice clasts are light pink, argillically altered (average $<10 \mathrm{~mm}$, maximum $35 \mathrm{~mm}$ ). Rare lithic clasts $(<3 \mathrm{~mm})$.

Non- to partially welded subzone (Tpcpv1)

4.8 Pyroclastic-flow deposit, moderate gray to dark gray upward, nonwelded, degree of sintering increases upward, vitric. Normally graded pumice clasts (maximum $\sim 20 \mathrm{~mm}$ in the basal $40 \mathrm{~cm}$ ).

1.4 Pyroclastic-flow deposit, moderate gray, nonwelded, vitric. Pumice clasts are coarse and normally graded in basal $15 \mathrm{~cm}$. Pumice clasts are light pink and vapor-phase altered or light gray and vitric. Top is marked by a 5 -cm-thick flow parting with fine laminations and faint crossbedding.

0.05 Pumiceous fallout deposit, bed pinches, and swells. Ninety percent pumice clasts (average $<30 \mathrm{~mm}$ ). Ten percent maroon rhyolite lithic clasts (average $<20 \mathrm{~mm}$ ). 


\section{Pre-Tiva Canyon Tuff bedded tuff (Tpbt4)}

$0.4 \quad$ Unit B - Paleosol on pumiceous fallout deposit, dark red to pink. Base not exposed.

2.25 Covered interval.

\section{Yucca Mountain Tuff (Tpy)}

6.0 Pyroclastic-flow deposit, pinkish gray, moderately welded. Clear glass shards with vapor-phase mineralization. Top of unit is covered.

5.5 Pyroclastic-flow deposit, orange, densely welded.

2.0 Pyroclastic-flow deposit, medium to dark gray, partially to moderately welded. Deformed glass shards are black, vitric. Orange pumice clasts $(<10 \mathrm{~mm})$.

1.5 Pyroclastic-flow deposit, light gray, nonwelded. Dominantly glass shards.

\section{Pre-Yucca Mountain Tuff bedded tuff (Tpbt3)}

0.3 Covered interval.

0.7 Unit G - Fine-grained pumiceous fallout deposit. Two units (lower $=40 \mathrm{~cm}$, upper $=30 \mathrm{~cm}$ ). Seventy percent pumice clasts $(<5 \mathrm{~mm})$. Twenty percent lithic clasts include gray glass, red porphyritic devitrified volcanics, pink and gray banded rhyolite. Ten percent crystals include feldspar.

0.15 Unit F - Lithic- and pumice-rich fallout deposit with one or two interbedded fine ash layers. Fifty percent pumice clasts $(<15 \mathrm{~mm})$. Thirty percent lithic clasts include gray glass, red porphyritic devitrified volcanics, pink and gray banded rhyolite.

Unit E -

2.0 Pumiceous pyroclastic-flow deposit, grayish yellow, nonwelded. Top is irregular, locally fine grained, and pink (paleosol?). Pumice clasts are blocky in a coarse-grained matrix. Crude inverse grading defined by pumice clasts (up to $63 \times 49 \mathrm{~cm}$ near top). Five percent lithic clasts include gray glass, pink and gray banded rhyolite $(<15 \mathrm{~mm})$.

0.2 Pumiceous fallout deposit. Sixty five to 75 percent pumice clasts (mostly $<12 \mathrm{~mm}$, maximum $25 \mathrm{~mm}$ ). Fifteen and 20 percent lithic clasts are mostly gray glass $(<7 \mathrm{~mm})$. Ten to 15 percent crystals, including feldspar and rare biotite. Crude bedding.

1.2 Pumiceous pyroclastic-flow deposit, grayish yellow, nonwelded. Blocky pumice in a coarse-grained matrix (maximum $70 \times 30 \mathrm{~mm}$ ). Less than 1 percent lithic clasts include gray glass $(<15 \mathrm{~mm})$. Basal $2 \mathrm{~cm}$ is fine grained with crude bedding.

$0.4 \quad$ Pumiceous fallout deposit. Crude inverse grading. Pumice clasts contain 5 percent crystals (mostly $<15 \mathrm{~mm}$, rarely to $40 \mathrm{~mm}$ ). Five percent lithic clasts include gray glass, dark-red devitrified volcanics, pink and gray banded rhyolite (mostly $<3 \mathrm{~mm}$, rarely to $10 \mathrm{~mm}$ ).

0.2 Covered interval.

1.25 Pumiceous pyroclastic-flow deposit, grayish yellow, nonwelded. Blocky pumice (up to $40 \times 20 \mathrm{~mm}$ ) in a coarse-grained matrix. Less than 1 percent lithic clasts include gray glass $(<5 \mathrm{~mm})$.

21.75 Pyroclastic-flow deposit, buff, nonwelded to partially welded. Several flow units $(\sim 1 \mathrm{~m}$ thick $)$ in top, massive below. Twenty percent pumice clasts that contain 2 percent crystals $(<50 \mathrm{~mm})$. Five to 7 percent lithic clasts at base increasing to $15-20$ percent then decreasing to $2-3$ percent at top, pink and gray banded rhyolite, black poorly vesicular glass, reddish-brown porphyritic devitrified volcanics, pink welded tuff, and rare brown to yellow nonwelded tuff (mostly $<40 \mathrm{~mm}$ ).

7.5 Covered interval. 98 Stratigraphic Relations and Hydrologic Properties of the Paintbrush Tuff Nonwelded (PTn) Hydrologic Unit,
Yucca Mountain, Nevada 
3.6 Pyroclastic-flow deposit, light gray, nonwelded. Twenty percent pumice clasts (mostly $<30 \mathrm{~mm}$ ). Twenty-five percent lithic clasts at base to $<10$ percent at top, include pink and gray banded rhyolite, dark-red devitrified volcanics, greenish-gray glass, and rare pink granitic (mostly $<25 \mathrm{~mm}$ ).

0.75-0.8 Unit D - Lithic-rich fallout deposit, several massive to crudely normally graded beds. Seventy percent pumice clasts (mostly $<40 \mathrm{~mm}$ ); 35 percent lithic clasts include pink and gray banded rhyolite, dark-red devitrified volcanics, greenish-gray glass, and rare pink granitic (mostly $<30 \mathrm{~mm}$, rarely up to $80 \mathrm{~mm}$ ).

0.8-0.95 Unit C - Tuff (genesis unknown), gray, nonwelded. Contains a discontinuous lithic- and pumice-rich horizon $\sim 30 \mathrm{~cm}$ from top. Base is poorly stratified, top is massive. Eighty percent pumice clasts (mostly $<5 \mathrm{~mm})$. Ten percent lithic clasts include pink and gray banded rhyolite, dark-red devitrified volcanics, and rare gray glass (mostly $<5 \mathrm{~mm}$ ).

1.2 Unit B (?) - Pyroclastic-flow deposit, tan to gray, nonwelded. Crude normal grading. Twenty to 25 percent pumice clasts at base to $10-15$ percent at top (mostly $<20 \mathrm{~mm}$ ). Three percent lithic clasts include pink and gray banded rhyolite, dark-red devitrified volcanics, and rare gray glass.

$0.7 \quad$ Covered interval.

$0.4 \quad$ Unit A - Pumiceous fallout deposit. Sixty to 70 percent pumice clasts (mostly $<35 \mathrm{~mm}$, rarely up to $55 \mathrm{~mm}$ ). Twenty percent lithic clasts include pink and gray banded rhyolite, dark-red devitrified volcanics, and gray glass (mostly $<20 \mathrm{~mm}$, rarely up to $55 \mathrm{~mm}$ ).

\section{Pah Canyon Tuff (Tpp)}

0.9 Pyroclastic-flow deposit, orange-pink, nonwelded. Ten percent pumice clasts at base to 20 percent at top, light gray (mostly $<20 \mathrm{~mm}$, up to $11.5 \times 5 \mathrm{~cm}$ ). Less than 1 percent lithic clasts include darkgray to dark-red devitrified volcanics $(<10 \mathrm{~mm})$.

5.1 Pyroclastic-flow deposit, orange-pink, nonwelded. Seven to 10 percent pumice clasts, mostly light gray and rarely yellow with crystal clots (mostly $<60 \mathrm{~mm}$, up to $23 \times 20 \mathrm{~cm}$ ). One percent lithic clasts include dark-gray devitrified volcanics $(<10 \mathrm{~mm})$.

Pyroclastic-flow deposit, orange-pink, nonwelded. Twenty-five to 30 percent pumice clasts, yellow, contain clots of crystals (up to $40 \times 26 \mathrm{~cm}$ ). One to 2 percent lithic clasts include red devitrified volcanics $(<20 \mathrm{~mm})$. Three percent crystals.

\section{Base covered}

\section{Measured stratigraphic section on the eastern side Solitario Canyon (section PTn\#2)}

Location description: North of borehole USW UZ-N80 and south of borehole USW H-6 on east side of canyon. Approximate location of top of section: N758093 E557782 (Nevada state coordinate system), elevation $4,600 \mathrm{ft}$.

Strike and dip of bedding: 334 (N26W), 9 (NE) on base of Tpbt4 and 339, 10 on fallout deposit in Tpbt3.

Line of section: 64 , dip in line of section is 9 .

Stratigraphic

Thickness

(meters) 


\section{Top of section}

Tiva Canyon Tuff (Tpc)

Crustal-poor vitric zone (Tpcpv)

Non- to partially welded subzone (Tpcpv1)

\section{Pre-Tiva Canyon Tuff bedded tuff (Tpbt4)}

0.55 Unit B - Pumiceous fallout deposit, gray grading upward to a red paleosol. Pumice clasts (greater than 90 percent) are light gray, vitric, 1 to $2 \mathrm{~mm}$. Laminations visible near base of unit. Top of unit is mostly covered.

\section{Pre-Yucca Mountain Tuff bedded tuff (Tpbt3)}

1.19 Unit G - Tan, slightly reworked fallout deposit. Textural break $28 \mathrm{~cm}$ from top of unit (based on field relations approximately $500 \mathrm{~m}$ to the north, the material above break may represent reworked lateral equivalent of the Yucca Mountain Tuff). Fallout deposit below textural break is moderately sorted. Pumice clasts (80-85 percent) are white and light gray to orange-brown, most are 1 to $3 \mathrm{~mm}$, with numerous larger clasts (up to $25 \mathrm{~mm}$ ). Lithic clasts (10-15 percent) are mostly less than $3 \mathrm{~mm}$, rarely to $7 \mathrm{~mm}$, dominantly clear to light-gray glass with subordinate brown and gray devitrified volcanics. Crystals (1-2 percent?) are hard to distinguish from small glass lithic clasts. Above the textural break, the rock is finer grained and there is up to 10 percent brown matrix. Burrows, up to $8 \mathrm{~cm}$ in diameter, are present in the upper part of the unit.

$0.10 \quad$ Unit F - Fallout deposit. Pumice clasts (70-80 percent) are light gray, vitric, 2 to $5 \mathrm{~mm}$. Lithic clasts (20-30 percent) include dominant clear glass and subordinate gray to pale-red devitrified volcanics. Crystals (1-5 percent) include feldspar and oxidized biotite (feldspar is hard to distinguish from small glass lithic clasts).

0.52 Unit D - Fallout deposit. Pumice clasts (greater than 90 percent) are white to very light gray, vitric, 5 to $15 \mathrm{~mm}$. Lithic clasts (5-7 percent) include dominant devitrified volcanics, pinkish-gray, moderate red, pale-red, and subordinate gray perlitic glass. Crystals (2-3 percent) include feldspar.

0.54 Unit C - Tan, slightly reworked fallout deposit. Pumice clasts ( $80-90$ percent) are subrounded, white, vitric, mostly 1 to $3 \mathrm{~mm}$ with rare clasts to $20 \mathrm{~mm}$. Lithic clasts (2-5 percent) are dominantly gray and pale-red devitrified volcanics with subordinate clear glass. Crystals ( $1-2$ percent) include feldspar and rare oxidized biotite. Tan matrix ( $2-5$ percent) coating grains. Lower contact is irregular.

1.7 Unit B - Orange-brown, reworked, coarse fallout deposit. Pumice clasts (70-80 percent) are white to light gray, vitric to slightly altered, 5 to $20 \mathrm{~mm}$, and crystal rich. Orange matrix comprises 15 to 25 percent in base of unit and increases toward the top. Lithic clasts ( $3-5$ percent) are 2 to $5 \mathrm{~mm}$ and include light-brown and pale-red devitrified volcanics and rare clear glass. Crystals (2-3 percent) include feldspar and oxidized biotite.

0.40 Unit A - Gray, pumiceous, coarse fallout deposit. Pumice clasts (about 90 percent) are white to light gray, vitric to slightly altered, 2 to $15 \mathrm{~mm}$. Lithic clasts (2-3 percent) include gray and pale-red devitrified volcanics and rare gray perlitic glass, mostly less than $5 \mathrm{~mm}$. Crystals $(5-7$ percent) include feldspar, oxidized biotite, and rare clinopyroxene (?). 
Topopah Spring Tuff (Tpt) and Pre-Pah Canyon Tuff bedded tuff (Tpbt2)

Crystal-rich vitric zone (Tptrv) and bedded tuff(Tpbt2)

Non- to partially welded subzone (Tptrv3) and bedded tuff (Tpbt2) undifferentiated

8.4 Mostly covered. Non- to partially welded fallout deposit. Pumice clasts are vitric to altered. Change from gray to brown pumice clasts $1.2 \mathrm{~m}$ above the base of the unit.

Moderately welded subzone (Tptrv2)

1.6

Moderately welded fallout deposit. Pumice clasts (about 90 percent) are gray, 10 to $20 \mathrm{~mm}$, altered to vitric.

Densely welded subzone (Tptrv1)

Base of section

\section{Measured stratigraphic section on the eastern side of Solitario Canyon (section PTn\#3)}

Location description: West and south of borehole USW UZ-6s on the east side of Solitario Canyon.

Approximate location of top of section: $759,530 \mathrm{~N} 557,450 \mathrm{E}$ (Nevada state coordinate system), elevation $4,620 \mathrm{ft}$.

Strike and dip of bedding: $7^{\circ}$ (N7E), $9^{\circ} \mathrm{SE}$ on base of Tpbt 3 unit D; $15^{\circ}$ (N15E), $3^{\circ} \mathrm{SE}$ on base of Tpbt $4 ; 0^{\circ}$ (N10E), $8^{\circ} \mathrm{SE}$ on bedding break within Tpbt3 unit D.

Line of section: Top of Tptrv1 to ash layer 2 (within Tpbt2): $135^{\circ}$ (S45E), dip in line of section is $5^{\circ}$. Section is offset approximately $20 \mathrm{~m}$ southward along ash layer 2 . Top of ash layer 2 (Tpbt2) to top of Tpbt4: $100^{\circ}$ ( $\mathrm{S} 80 \mathrm{E}$ ), dip in line of section is $8^{\circ}$. Section is offset approximately $10 \mathrm{~m}$ northward along the base of the Tiva Canyon Tuff. Top of Tpbt4 to base of Tpcpv3: $100^{\circ}$ (S80E), dip in line of section is $8^{\circ}$.

\section{Stratigraphic}

Thickness

(meters)

Top of section

Tiva Canyon Tuff (Tpc)

Crustal-poor vitric zone (Tpcpv)

Densely welded subzone (Tpcpv3)

Moderately welded subzone (Tpcpv2)

1.6 Pyroclastic-flow deposit. Yellow to tan, with abundant, deformed glass shards. Pumice clasts (7 to 10 percent) are deformed, light gray to pinkish gray, and mostly from 2 to $10 \mathrm{~mm}$ (rare to $20 \mathrm{~mm}$ ).

Phenocrysts ( 1 to 2 percent) of feldspar. Lithic clasts ( 2 percent) of red, gray, and brown devitrified volcanic rock. Flow boundary marked by a $5-\mathrm{cm}$-thick layer with abundant crystals and glass shards and well-developed laminations occurs $1.2 \mathrm{~m}$ below upper contact.

$0.8 \quad$ Covered interval.

Non- to partially welded subzone (Tpcpv1)

3.6 Pyroclastic-flow deposit. Yellow to tan, with abundant, non- to slightly deformed glass shards. Pumice clasts ( 7 to 10 percent) are nondeformed, light gray (vitric) to pinkish gray (altered), and mostly from 2 to $10 \mathrm{~mm}$ (rare to $20 \mathrm{~mm}$ ). Phenocrysts (1 to 2 percent) of feldspar. Lithic clasts ( 2 percent) of red, gray, and brown devitrified volcanic rock. Base of unit marked by a 5-cm-thick pumiceous ground layer. 


\section{Pre-Tiva Canyon Tuff bedded tuffs (Tpbt4)}

0.9 Unit B - Pumiceous fallout deposit. Massive, clast-supported deposit of white, vitric pumice clasts that are typically $1-3 \mathrm{~mm}$ in size. Basal few centimeters of deposit are laminated. Grades upward into a red paleosol. Upper contact is sharp; lower contact locally is disturbed by burrowing.

\section{Yucca Mountain Tuff (Tpy)}

$0.8 \quad$ Nonwelded pyroclastic-flow deposit. Yellow to tan, massive, poorly sorted deposit with abundant amber to colorless bubble-textured glass shards, lithic clasts ( 1 to 2 percent) of devitrified volcanic rock smaller than $2 \mathrm{~mm}$, sparse pumice clasts, and phenocrysts (less than 1 percent) of feldspar. Upper $10 \mathrm{~cm}$ are reworked, tan to brown, with approximately 5 percent lithic clasts to $15-\mathrm{mm}$ diameter. Basal $5 \mathrm{~cm}$ is a prominent ground layer composed of centimeters-sized clasts of pumice ( 60 percent) and lithics ( 40 percent). The tuff thins rapidly to the south.

\section{Pre-Yucca Mountain Tuff bedded tuffs (Tpbt3)}

0.6 Unit G - Reworked (?) pumiceous deposit. Tan, poorly sorted, clast-supported deposit that is composed of 40 to 50 percent, gray to tan pumice clasts ( 1 to $30 \mathrm{~mm}$ in size); 40 to 50 percent lithic clasts ( 1 to $10 \mathrm{~mm}$ ), predominantly gray glass with subordinate gray to red devitrified volcanic rock; 2 to 3 percent crystals of feldspar; and less than 10 percent matrix. Upper contact is sharp.

0.3 Unit F - Slightly reworked fallout deposit. Tan, moderately sorted, laminated deposit of gray, vitric pumice ( 50 to 60 percent), typically 1 to $15 \mathrm{~mm}$ in size; lithic clasts ( 40 to 50 percent), mostly gray, glassy volcanic rock with subordinate devitrified volcanic rock; and 1 to 2 percent crystals of feldspar (?). Upper contact is diffuse; lower contact is sharp.

0.4 Unit D - Coarse, pumiceous fallout deposit. A clast-supported deposit of white to light-gray, vitric pumice ( 60 to 70 percent), typically from 3 to $15 \mathrm{~mm}$ in size; lithic clasts ( 25 to 35 percent) predominantly of gray, brown, and red devitrified volcanic rock with subordinate gray glass; and crystals ( 2 to 5 percent) of feldspar and rare oxidixed biotite. Lower contact is sharp.

0.5 Unit C - Reworked deposit. Massive, brown, poorly sorted deposit containing abundant (70 to 80 percent) pumice clasts of 1 to $3 \mathrm{~mm}$ size, lithic clasts (10 to 15 percent) of gray to red devitrified volcanic rock and minor gray, glassy lava, and 3 to 5 percent crystals of feldspar. Matrix comprises 10 percent. Lower contact is diffuse.

0.8 Unit B - Reworked fallout deposit. Massive, poorly sorted, reddish-brown deposit containing 40 to 50 percent gray pumice clasts (to $40 \mathrm{~mm}$ ), 5 to 10 percent crystals of feldspar, biotite, and hornblende, and 40 to 50 percent matrix. Lower contact is sharp.

0.3 Unit A - Coarse, pumiceous fallout deposit. A clast-supported deposit composed of approximately 90 percent white, vitric pumice clasts of 5 to $25 \mathrm{~mm}$ in size; 2 to 3 percent lithic clasts of gray devitrified volcanic rock and colorless glass, typically 2 to $4 \mathrm{~mm}$ in size; and 5 to 7 percent crystals of feldspar and oxidized biotite. The lower contact is irregular and disturbed by burrowing.

\section{Pre-Pah Canyon Tuff bedded Tuffs (Tpbt2)}

0.9 Unit D - Reworked (?) deposit. Massive, poorly sorted, light-brown deposit that contains pink and light-gray pumice clasts ( 30 to 40 percent) that are from 3 to $15 \mathrm{~mm}$ in size; lithic clasts (5 to 7 percent) that include gray to red devitrified volcanic rocks and light-gray to black, glassy volcanic rocks; and crystals ( 7 to 10 percent) of feldspar and biotite, with rare pyroxene. The matrix is vitric to slightly altered with a granular texture.

Covered interval.

Unit C - Coarse, pumiceous fallout deposit. Massive to crudely layered (in the upper half), moderately sorted, clast-supported, very pale-orange to light-gray deposit that contains light-gray, vitric pumice clasts ( 80 percent) that are from 15 to $30 \mathrm{~mm}$ in size; lithic clasts ( 10 percent) of gray to pink 
and dark grayish-red devitrified volcanic rock and black to brown, glassy volcanic rock that are from 10 to $20 \mathrm{~mm}$ in size; and crystals ( 7 to 10 percent) of feldspar, biotite, and minor pyroxene. The lower contact is not stratiform and varies by a few meters over a horizontal distance of a few tens of meters.

3.2 Unit B - Altered, pumiceous fallout deposit. Massive, moderately sorted, clast-supported (appears matrix supported on first glance), moderate orange-brown deposit that contains moderate brown, altered pumice clasts ( 70 percent) and light-gray, vitric pumice clasts ( 10 percent) that are from 15 to $30 \mathrm{~mm}$ in size; lithic clasts (10 percent) of gray to pink and dark grayish-red devitrified volcanic rock and black to brown, glassy volcanic rock that are from 10 to $20 \mathrm{~mm}$ in size; and crystals (10 to 12 percent) of feldspar, biotite, and minor pyroxene. Ash layer 2, which occurs $1.4 \mathrm{~m}$ below the upper contact, consists of $2 \mathrm{~cm}$ of pale orange-pink ash overlain by a lithic-rich horizon of brown, glassy volcanic fragments. This marker horizon is overlain by $10 \mathrm{~cm}$ of a light-gray pumice-fall deposit that contains crystals of feldspar, biotite, and pyroxene; and lithic clasts of devitrified and glassy volcanic rock. Ash layer 1 marks the base of the section.

\section{Topopah Spring Tuff (Tpt)}

\section{Crvstal-rich vitric zone (Tptrv) Non- to partially welded subzone (Tptrv3)}

1.0 Unit B - Altered, pumiceous fallout deposit. Massive, moderately sorted, clast-supported (appears matrix supported on a first glance), moderate orange-brown deposit that contains nondeformed, moderate brown, altered pumice clasts ( 70 percent) and light-gray, vitric pumice clasts ( 10 percent) that are from 15 to $30 \mathrm{~mm}$ in size; lithic clasts ( 5 to 15 percent) are mostly of gray to pink and dark grayish-red devitrified volcanic rock with rare clasts of black, glassy volcanic rock that are from 10 to $20 \mathrm{~mm}$ in size; and crystals ( 8 to 10 percent) of feldspar, biotite, and minor pyroxene. Ash layer 1 is a 2-cm-thick horizon of lithic-rich fallout that contains fragments of devitrified volcanic rock and rare glass. Lower contact is gradational over a few tens of centimeters and occurs where gray pumice clasts increase downward to more than 10 percent.

1.1 Unit A - Pumiceous fallout deposit. Massive to crudely stratified, moderately well-sorted, clastsupported deposit that contains moderate brown and medium to light-gray, nondeformed pumice clasts (smaller than $15 \mathrm{~mm}$ ); lithic clasts (15 percent) of pink to gray devitrified volcanic rock that are less than $5 \mathrm{~mm}$ in size; and crystals of feldspar, biotite, and rare pyroxene ( 5 to 7 percent) that decrease downward to 3 to 5 percent (feldspar and biotite). Lower contact is marked by the onset of pumice-clast deformation.

\section{Moderately welded subzone (Tptrv2)}

1.0 Pumiceous fallout deposit. Massive to crudely stratified, moderately well-sorted, clast-supported deposit that contains variably deformed, moderate brown and medium to light-gray pumice clasts (smaller than $15 \mathrm{~mm}$ ); lithic clasts (15 percent) of pink to gray devitrified volcanic rock that are less than $5 \mathrm{~mm}$ in size; and crystals of feldspar and rare biotite ( 2 to 4 percent). Porosity decreases markedly downward. Lower contact is abrupt.

Densely welded subzone (Tptrv1)

Vitrophyre. Brown, densely welded, glassy tuff with black to gray fiamme that grades downward to dense, reddish-brown glass.

\section{Base of Section}




\section{Measured stratigraphic section on the eastern side Solitario Canyon (section PTn\#4)}

Location description: East side of Solitario Canyon, just north of large northeast-trending fault. Section was measured in gully with excellent exposures.

Approximate location of top of section: N764900 E558150 (Nevada state coordinate system), elevation $4,500 \mathrm{ft}$.

Strike and dip of bedding: $0,6(\mathrm{E})$ on fallout deposit in Tpbt3.

Line of section: From top of Topopah Spring Tuff vitrophyre to base of exposures of Pah Canyon Tuff is 135, dip in line of section is 3; from base of exposures of the Pah Canyon Tuff to top of section is 95, dip in line of section is 6 .

Note: Outcrops were wet, and colors listed here are typically darker than those for dry outcrop.

Stratigraphic

Thickness

(meters)

Top of section

Tiva Canyon Tuff (Tpc)

Crystal-poor lower nonlithophysal zone (Tpcpln)

Columnar subzone (Tpcplnc)

Crustal-poor vitric zone (Tpcpv)

Densely welded subzone (Tpcpv3)

2.1 Densely welded pyroclastic-flow deposit, orange-pink. Matrix contains brown to black, strongly deformed shards defining a well-developed foliation. Matrix porosity is absent. Five to 10 percent black fiamme. Lithic clasts and crystals as below. Degree of devitrification increases upward. Upper contact is defined by complete devitrification of shards. Lower contact is poorly exposed.

$2.4 \quad$ Covered interval.

Moderately welded subzone (Tpcpv2)

2.0 Moderately welded pyroclastic-flow deposit, dark grayish yellow to orange-pink at top. Matrix contains black, vitric shards that are slightly to strongly deformed upward. Remnant porosity decreases upward. Pumice clasts (15-25 percent) are slightly to strongly deformed upward, pink grading upward to mixture of pink and black fiamme. Lithic clasts (1-2 percent) include pale-red to grayishred devitrified volcanic rock, up to $10 \mathrm{~mm}$. Crystals as below. Lower contact is poorly exposed.

Non- to partially welded subzone (Tpcpvl)

2.0 Basal $20 \mathrm{~cm}$ : Reverse-graded pumiceous deposit. Pumice clasts ( $30-40$ percent) are pinkish gray, vitric, 5 to $15 \mathrm{~mm}$ grading upward to 10 to $30 \mathrm{~mm}$ (up to $50 \mathrm{~mm}$ ). One percent lithic clasts and 1 to 2 percent crystals in a gray, vitric matrix.

Upper $1.8 \mathrm{~m}$ : Non- to partially welded pyroclastic-flow deposit. Matrix contains black, vitric, nonto slightly deformed shards. Pumice clasts (10-20 percent) are pinkish gray, vitric, 1 to $25 \mathrm{~mm}$, nonto slightly deformed. Lithic clasts (1-2 percent) include pale-red devitrified volcanic rock and very dark-gray glass, less than $5 \mathrm{~mm}$. Crystals (1-2 percent) include feldspar. 


\section{Pre-Tiva Canyon Tuff bedded tuff (Tpbt4)}

1.5 Unit B - Well-sorted, pumiceous fallout deposit; structureless, light gray to pinkish gray grading upward to orange-red. Middle of unit is poorly exposed. Pumice clasts ( $80-90$ percent) are white to very light gray to pink, vitric, 2 to $5 \mathrm{~mm}$. Lithic clasts (2 percent) include gray glass and pinkishgray to brown devitrified volcanic rock, 1 to $2 \mathrm{~mm}$. Crystals (2-4 percent) include feldspar, rare biotite, and rare hornblende (?). Lower contact is irregular and undulates by 10 to $20 \mathrm{~cm}$.

\section{Yucca Mountain Tuff (Tpy)}

5.3 Nonwelded pyroclastic-flow deposit, medium gray grading upward to pale red (color change occurs 3 to $4 \mathrm{~m}$ from base of unit). Unit is massive and structureless. Abundant, vitric, bubble-wall shards in matrix, non-deformed throughout unit. Pumice clasts (3-7 percent) are moderate orange-pink and devitrified (?) to medium gray and vitric, typically less than $15 \mathrm{~mm}$. Lithic clasts (1-2 percent) include dark reddish-gray devitrified volcanic rock, less than $2 \mathrm{~mm}$, rarely to $10 \mathrm{~mm}$. Crystals ( 1 percent) include feldspar. Base of unit is marked by 1 - to 2 -cm-thick, lithic-rich ground layer; 40 percent lithic clasts, pale red, 5 to $30 \mathrm{~mm} ; 40$ percent pumice clasts; 10 percent crystals. The ground layer is overlain by $1-$ to 2 -cm-thick laminated ash layer. Top of unit is medium red below upper contact.

\section{Pre-Yucca Mountain Tuff bedded tuff (Tpbt3)}

Unit G - Poorly sorted, slightly reworked (?) fallout deposit. Pinkish brown to reddish orange-brown at top of unit. Pumice clasts (60-70 percent) are white with orange rims, vitric, less than 1 to $30 \mathrm{~mm}$. Lithic clasts (30 percent) are dominantly gray glass with subordinate pinkish-gray and gray devitrified volcanic rock and rare obsidian, 2 to $5 \mathrm{~mm}$, with some clasts to $25 \mathrm{~mm}$. Crystals (less than 2 percent) include feldspar (hard to distinguish from small glass lithic clasts). A poorly developed paleosol marks the top of the unit; upper contact is planar.

Unit F - Moderately to poorly sorted fallout deposit. Pumice clasts ( $40-50$ percent) are white, vitric, 5 to $10 \mathrm{~mm}$, rarely to $25 \mathrm{~mm}$. Lithic clasts (40 percent) include dominant gray glass and subordinate devitrified volcanic rock, less than 5 to $10 \mathrm{~mm}$. Crystals ( $1-5$ percent?) include feldspar (hard to distinguish from small glass lithic clasts). Faint bedding. Upper contact is sharp to indistinct.

Unit E - Ash-rich, light grayish-yellow, fine-grained fallout deposit. Pumice clasts (10 percent) are white, vitric. Lithic clasts (60 percent) include dominant gray glass and subordinate devitrified volcanic rock, 1 to $3 \mathrm{~mm}$. Crystals (less than 2 percent) include feldspar.

Unit D - Well-sorted, normally graded (?), coarse fallout deposit. Beds 3 to $15 \mathrm{~cm}$ thick. Pumice clasts (60-70 percent) are white, vitric, 10 to $30 \mathrm{~mm}$. Lithic clasts (25-30 percent) include dominant devitrified volcanic rock, light-gray, grayish-red, moderate red, with rusty alteration, and subordinate gray perlitic glass and reddish-brown glass, 2 to $10 \mathrm{~mm}$. Crystals $(2-3$ percent) include feldspar. In the upper $10 \mathrm{~cm}$ of the unit, grain size is 1 to $8 \mathrm{~mm}$, and there is no rusty alteration of lithic clasts.

0.6 Unit C - Tan, well-sorted, slightly reworked (?), clast-supported fallout deposit. Pumice clasts (80-90 percent) are white, vitric, 1 to $3 \mathrm{~mm}$. Lithic clasts (2-5 percent) are dominantly brown and reddish-gray devitrified volcanic rock with subordinate gray glass. Crystals (2-3 percent) include feldspar and rare biotite. Upper contact is sharp and planar. There is a small north-trending fault, with approximately $20 \mathrm{~cm}$ of offset, that cuts this unit.

0.2 Unit B - Reddish-brown, poorly sorted, reworked (?), coarse fallout deposit. Pumice clasts (40-50 percent) are white with orange-brown rims, vitric, 1 to $10 \mathrm{~mm}$. Lithic clasts $(10-20$ percent $)$ are less than $2 \mathrm{~mm}$ and include dominant devitrified volcanic rock and rare gray glass. Crystals (2-5 percent) include feldspar. Upper contact is gradational over $5 \mathrm{~cm}$. 


\section{Pah Canyon Tuff (Tpp)}

2.0 As below, except pumice clasts are primarily light gray and vitric, and lithic-clast content drops to 1 to 2 percent.

3.5 Coarse, pumiceous pyroclastic-flow deposit. Reddish-brown matrix. Pumice clasts ( $30-40$ percent) are dominantly yellow and vitric with crystals of feldspar and oxidized biotite, and subordinate gray and vitric, 10 to $30 \mathrm{~mm}$, with blocks to $15 \mathrm{~cm}$. Lithic clasts (3-7 percent) include reddish-gray devitrified volcanic rock and minor black to reddish-brown glass, 5 to $30 \mathrm{~mm}$. Crystals (5-7 percent) include feldspar and oxidized biotite. Lowest meter is finer grained than above. Upper contact is poorly exposed, abrupt, and irregular (depositional).

2.2 Coarse, pumiceous pyroclastic-flow deposit. Grayish-brown matrix. Pumice clasts (40-50 percent) are light to medium gray and vitric, 20 to $50 \mathrm{~mm}$, with blocks to $20 \mathrm{~cm}$. Lithic clasts (1-3 percent) include black glass and dark reddish-gray devitrified volcanic rock, 5 to $10 \mathrm{~mm}$. Crystals (5-10 percent) include feldspar, oxidized biotite, and rare pyroxene.

\section{Pre-Pah Canyon Tuff bedded tuff (Tpbt2)}

$6.2 \quad$ Covered interval.

1.8 Pumiceous, poorly sorted fallout deposit. Pumice clasts (60-80 percent) are light gray and vitric or yellowish brown and altered, 10 to $30 \mathrm{~mm}$. Lithic clasts (7-10 percent) are reddish-gray and brown devitrified lava and black to brown glass, 5 to $15 \mathrm{~mm}$. Crystals (5-10 percent) include feldspar, oxidized biotite, and rare pyroxene. Unit is poorly exposed.

3.7 Covered interval.

\section{Topopah Spring Tuff (Tpt)}

Crystal-rich vitric zone (Tptrv)

Densely welded subzone (Tptrv1)

\section{Base of section}

\section{Measured stratigraphic section on the eastern side Solitario Canyon (section PTn\#5)}

Location description: Section PTn\#5 is located on the east side of Solitario Canyon, several hundred meters south of measured section PTn\#4. The section is in the same location as hydrologic properties traverse SB-22 (Flint and others, 1996). To document rapid lateral thickness variations of the units, additional thickness measurements were made in a gully approximately $30 \mathrm{~m}$ to the south of PTn\#5 and are listed here as section PTn\#5A.

Approximate location of base of section PTn\#5: N763100 E557900 (Nevada state coordinate system), elevation 4,500 ft. Approximate location of base of section PTn\#5A: N763000 E557900 (Nevada state coordinate system), elevation $4,500 \mathrm{ft}$.

Strike and dip of bedding: Average of 328, 8 (E) on top of Tpy, base of Tpy, and base of Tpp.

Line of section: For PTn\#5, line is 110, dip in line of section is approximately 3.5. For PTn\#5A, line is 55 , dip in line of section is approximately 6.

Note: Outcrops were wet, and colors listed here are typically darker than those for dry outcrop.

Stratigraphic

Thickness

(meters)

106 Stratigraphic Relations and Hydrologic Properties of the Paintbrush Tuff Nonweided (PTn) Hydrologic Unit, Yucca Mountain, Nevada 


\section{Top of section \\ Tiva Canyon Tuff (Tpc)}

Crystal-poor lower nonlithophysal zone (Tpcpln)

Columnar subzone (Tpcplnc)

Moderately to densely welded, devitrified pyroclastic-flow deposit.

Crvstal-poor vitric zone (Tpcpv)

Moderately welded subzone (Tpcpv2)

4.0 Moderately welded pyroclastic-flow deposit. Unit as below except for increased welding and the presence of black fiamme near top of unit. Porosity very low in upper part of unit.

Non- to partially welded subzone (TpcpvI)

2.6 Non- to partially welded pyroclastic-flow deposit. Matrix contains yellowish-brown to black, vitric, non- to slightly deformed bubble-wall shards. Pumice clasts (15-20 percent) are yellowish gray to pinkish gray, vitric, 3 to $30 \mathrm{~mm}$, non- to slightly deformed. Lithic clasts (5-7 percent) include reddish-gray devitrified volcanic rock, medium gray glass, and porphyritic obsidian, less than $5 \mathrm{~mm}$. Lower contact is not exposed.

\section{Pre-Tiva Canyon Tuff bedded tuff (Tpbt4)}

0.9 Covered interval.

0.4 Unit B - Well-sorted, pumiceous fallout deposit; structureless, light gray to pale red. Pumice clasts ( 90 percent) are vitric, 1 to $2 \mathrm{~mm}$. Lithic clasts (7-10 percent) include gray glass and grayish-red devitrified volcanic rock. Crystals (less than 2 percent) include feldspar.

\section{Yucca Mountain Tuff (Tpy)}

6.4 Lowest $5 \mathrm{~cm}$ : Lithic-rich ground layer containing: 30 to 40 percent pumice clasts, light gray to white, vitric, 2 to $20 \mathrm{~mm} ; 30$ to 40 percent lithic clasts, pale-red to grayish-red devitrified volcanic rock, less than $10 \mathrm{~mm}$, up to $45 \mathrm{~mm}$; less than 2 percent crystals including feldspar; and light-gray ash.

Above basal $5 \mathrm{~cm}$ : Nonwelded, light-gray, pyroclastic-flow deposit. Unit is massive and structureless. Abundant, vitric, clear bubble-wall shards in matrix. Pumice clasts ( 2 percent) are light gray to pinkish gray, vitric, 1 to $5 \mathrm{~mm}$, rarely to $30 \mathrm{~mm}$. Lithic clasts (1 percent) include pale-red and dark reddish-brown devitrified volcanic rock and medium gray glass, less than $3 \mathrm{~mm}$. Crystals (less than 1 percent) include feldspar. Approximately $2 \mathrm{~m}$ above the base of the unit, the color grades to yellowish brown, pumice-clast content increases to 3 to 5 percent (up to 25-mm diameter), and shards in matrix are brownish yellow and very slightly deformed (?). Approximately $5.5 \mathrm{~m}$ above the base of the unit, the color grades to pinkish brown, pumice-clast content increases to 5 percent, and shards in the matrix are nondeformed. Top of unit is medium red below upper contact. Lower contact is sharp.

\section{Pre-Yucca Mountain Tuff bedded tuff (Tpbt3)}

0.2 Unit G - Clast-supported, slightly reworked (?) fallout deposit. Pumice clasts (70-80 percent) are light gray to light tan, slightly rounded (?), vitric, typically 1 to $4 \mathrm{~mm}$. Lithic clasts (10-15 percent) are dominantly clear to gray glass with subordinate pale-red devitrified volcanic rock, 1 to $3 \mathrm{~mm}$. Crystals (2-3 percent?) include feldspar (hard to distinguish from small glass lithic clasts). Unit contains lowest plug holes from hydrologic properties traverse SB-22.

Covered interval. 
0.6 Unit A - Moderately sorted, gray, clast-supported, coarse fallout deposit. Pumice clasts (70-80 percent) are white to light gray, vitric. Lithic clasts (10-15 percent) include medium gray and brown devitrified volcanic rock and rare gray glass. Crystals (2-5 percent?) include feldspar and oxidized biotite.

\section{Pah Canyon Tuff (Tpp)}

2.1 Lenses and horizons with variable grain sizes suggest this is not a primary pyroclastic-flow deposit. Some horizons or lenses contain clast-supported material with pumice blocks of 20 to $160 \mathrm{~mm}$, and other horizons or lenses contain matrix-supported material with 20 to 40 percent pumice clasts. Pumice clasts are light gray and vitric. Pinkish-brown matrix. Lithic clasts (less than 2 percent) include pale-red devitrified volcanic rock, 1 to $2 \mathrm{~mm}$. Crystals (5-7 percent) include feldspar and biotite. Lower contact is very irregular.

\section{Pre-Pah Canyon Tuff bedded tuff (Tpbt2)}

0.5 Unit D - Bottom $35 \mathrm{~cm}$ of unit is laminated coarse sand with faint cross laminations (?). Top $20 \mathrm{~cm}$ of unit is very coarse, pebbly, sand with faint crossbedding. Pebble types are the same as lithic types in unit $\mathrm{C}$, with the addition of moderate brown porphyritic glass.

$0.7 \quad$ Covered interval.

0.4 Unit C - Poorly sorted, clast-supported, pumiceous fallout deposit, very pale orange. Pumice clasts ( 80 percent) are light gray, 5 to $20 \mathrm{~mm}$, rarely to $30 \mathrm{~mm}$. Lithic clasts ( $5-10$ percent) include dark grayish-red devitrified volcanic rock, very dark-gray porphyritic glass, pale orange-pink tuff, brownish-yellow vitric tuff, less than $10 \mathrm{~mm}$, rarely to $40 \mathrm{~mm}$. Crystals (5-7 percent?) include feldspar, oxidized biotite, rare pyroxene, and magnetite.

0.9 Unit B - Nonwelded, altered, poorly sorted fallout deposit, yellow orange-brown. Matrix is redbrown and altered. Pumice clasts (10-15 percent) are light gray, 10 to $20 \mathrm{~mm}$. Lithic clasts (10 percent) include reddish-gray to reddish-brown devitrified volcanic rock and pale orange-pink tuff with lithics and crystals of feldspar, 1 to $10 \mathrm{~mm}$, rarely to $30 \mathrm{~mm}$. Crystals (7-10 percent) include feldspar, oxidized biotite, and rare pyroxene.

$1.0 \quad$ Covered interval.

Topopah Spring Tuff (Tpt)

Crystal-rich vitric zone (Tptrv)

Densely welded subzone (Tptrv1)

Red-brown glass with black fiamme. Crystals (10-12 percent) include feldspar, biotite, and hornblende (?).

Base of section

\section{Section PTN\#5A - Unit thicknesses approximately $\mathbf{3 0}$ m south of section PTn\#5}

Stratigraphic

Thickness

(meters)

Top of section

Tiva Canyon Tuff (Tpc)

Crystal-poor lower nonlithophysal zone (Tpcpln)

Columnar subzone (Tpcplnc) 
Crystal-poor vitric zone (Tpcpv)

4.2 Moderately welded subzone (Tpcpv2)

2.3 Non-to partially welded subzone (Tpcpv1)

1.7 Covered interval.

$0.7 \quad$ Unit B

4.7 Yucca Mountain Tuff (Tpy)

$0.1 \quad$ Unit $\mathrm{G}$

$1.1 \quad$ Covered interval.

$0.3 \quad$ Unit D

1.9 Covered interval.

3.2 Pah Canyon Tuff (Tpp)

$0.05 \quad$ Unit D

0.95 Covered interval.

6.1 Unit C - Lower 2-cm-thick ash layer located at the basal contact of this unit.

$1.9 \quad$ Unit B

$0.3 \quad$ Covered interval.

$1.2 \quad$ Unit $\mathrm{A}$

Topopah Spring Tuff (Tpt)

Crystal-rich vitric zone (Tptrv)

Densely welded subzone (Tptrv1)

Base of section

\section{Measured stratigraphic section on the eastern side Solitario Canyon (section PTn\#6)}

Location description: East side of Solitario Canyon, section was measured in gully with excellent exposures.

The section is in the same location as hydrologic properties traverse SB-16 (Rautman and others, 1995).

Approximate location of middle of section: N761950 E557900 (Nevada state coordinate system), elevation $4,540 \mathrm{ft}$.

Strike and dip of bedding: 340,8 (E) on fallout deposit in Tpbt3.

Line of section: 94 , dip in line of section is 5.5 . 
Note: Some outcrops were wet, and colors listed here may be darker than those for dry outcrop.

Stratigraphic

Thickness

(meters)

Top of section

Tiva Canyon Tuff (Tpc)

Crystal-poor lower nonlithophysal zone (Tpcpln)

Columnar subzone (Tpcplnc)

Crustal-poor vitric zone (Tpcpv)

Moderately welded subzone (Tpcpv2)

3.7 Moderately welded pyroclastic-flow deposit, yellowish brown, welding increases upward and upper $50 \mathrm{~cm}$ is fairly dense. Matrix contains brown shards and pumice clasts slightly to strongly deformed upward. Pumice clasts (10-30 percent) are pink grading upward to mixture of pink and black fiamme, 5 to $25 \mathrm{~mm}$. Lithic clasts and crystals as below.

Non- to partially welded subzone (Tpcpv1)

3.0 Non- to partially welded pyroclastic-flow deposit. Yellowish-brown matrix contains black to yellowish-brown, vitric shards. Pumice clasts (20-30 percent) are pink and altered, and light gray to brown and vitric, 5 to $30 \mathrm{~mm}$, locally to $50 \mathrm{~mm}$, non- to slightly deformed. Lithic clasts (3-5 percent) include gray to red devitrified volcanic rock and very dark-gray glass, 1 to $10 \mathrm{~mm}$. Crystals (1-2 percent) include feldspar and very rare biotite.

\section{Pre-Tiva Canyon Tuff bedded tuff (Tpbt4)}

0.7 Unit B - Poorly exposed, pumiceous fallout deposit, top is red paleosol. Upper contact is very poorly exposed.

\section{Yucca Mountain Tuff (Tpy)}

1.0 Nonwelded pyroclastic-flow deposit, brownish yellow. Unit is massive and structureless. Abundant, yellow-brown to black, vitric, bubble-wall shards in matrix. Pumice clasts (less than 5 percent) are grayish pink. Lithic clasts (2-3 percent) include dark reddish-gray devitrified volcanic rock and dark-gray glass, less than 1 to $4 \mathrm{~mm}$. Crystals (less than 1 percent) include feldspar. Unit is poorly exposed. Top 10 to $20 \mathrm{~cm}$ of unit appears to be disturbed and reworked, and upper contact is very poorly exposed.

\section{Pre-Yucca Mountain Tuff bedded tuff (Tpbt3)}

0.35 Unit G - Poorly sorted, pinkish-gray to brown, slightly reworked (?) fallout deposit. Pumice clasts (50-60 percent) are light gray with brown rims, vitric, 1 to $5 \mathrm{~mm}$, rarely to $20 \mathrm{~mm}$. Lithic clasts (30-40 percent) are dominantly clear to gray glass with subordinate devitrified volcanic rock, 1 to $3 \mathrm{~mm}$ with some clasts to $8 \mathrm{~mm}$. Crystals (2-5 percent?) include feldspar (hard to distinguish from small glass lithic clasts). Upper contact is planar.

0.25 Unit F - Poorly sorted fallout deposit. Pumice clasts (60-70 percent) are light gray to pale yellow, vitric, 1 to $5 \mathrm{~mm}$, rarely to $12 \mathrm{~mm}$. Lithic clasts (30-35 percent) include dominant gray glass and subordinate devitrified volcanic rock, 1 to $3 \mathrm{~mm}$. Crystals (2-5 percent?) include feldspar (hard to distinguish from small glass lithic clasts). Faint bedding with some thin, fine ash beds. Upper contact is sharp to indistinct. Thickness varies laterally. 
Unit D - Bedded, moderately sorted, coarse fallout deposit. Pumice clasts ( $70-80$ percent) are light gray, vitric, 3 to $15 \mathrm{~mm}$, rarely to $30 \mathrm{~mm}$. Lithic clasts (25-30 percent) include dominant gray, brown, and red devitrified volcanic rock with rusty alteration, and subordinate gray perlitic glass, 2 to $10 \mathrm{~mm}$, rarely to $20 \mathrm{~mm}$. Crystals (1-2 percent) include feldspar and very rare biotite. Unit contains lowest plug holes from hydrologic properties traverse SB-16.

Unit C - Light-brown, moderately sorted, slightly reworked (?) fallout deposit. Pumice clasts (70-80 percent) are white, vitric, 1 to $3 \mathrm{~mm}$, rarely to $10 \mathrm{~mm}$. Lithic clasts (10-20 percent) are dominantly gray glass with subordinate brown and reddish-gray devitrified volcanic rock, rare very dark-gray glass. Crystals (5-7 percent) include feldspar and rare biotite. Upper contact is sharp and planar.

Unit B - Reddish-brown, poorly sorted, reworked (?), coarse fallout deposit. Pumice clasts (30-40 percent grading upward to $15-20$ percent) are light gray to pinkish gray with orange rims, vitric, 1 to $10 \mathrm{~mm}$. Lithic clasts (10-20 percent) are less than $2 \mathrm{~mm}$ and include dominant gray to brown devitrified volcanic rock and rare gray glass. Crystals (2-5 percent) include feldspar and biotite. Upper contact is gradational over $5 \mathrm{~cm}$.

0.5 Unit A - Clast-supported, light-gray, pumiceous fallout deposit. Pumice clasts ( $80-90$ percent) are white to light gray, vitric, 3 to $15 \mathrm{~mm}$. Lithic clasts (5-7 percent) include brown to gray devitrified volcanic rock and rare gray glass, 2 to $10 \mathrm{~mm}$. Crystals ( $3-5$ percent) include feldspar and oxidized biotite. The upper contact is gradational over 10 to $15 \mathrm{~cm}$.

\section{Pah Canyon Tuff (Tpp)}

0.8 Pyroclastic-flow deposit, pumice-clast supported at base of unit to matrix supported at top of unit. Pink, vitric matrix. Pumice clasts are light gray and vitric, with 40 - to $120-\mathrm{mm}$ blocks at base of unit. Lithic clasts (2-3 percent) types as below, 1 to $6 \mathrm{~mm}$. Crystals as below. Upper contact is sharp.

1.7 Pyroclastic-flow deposit. Grayish-pink, vitric to slightly altered matrix. Pumice clasts (20-30 percent) are light gray and vitric, 3 to $15 \mathrm{~mm}$ grading upward to 5 to $60 \mathrm{~cm}$. Lithic clasts (1-2 percent) include brown, pinkish-gray, and grayish-red devitrified volcanic rock, 1 to $5 \mathrm{~mm}$. Crystals (4-6 percent) include feldspar, biotite, and rare pyroxene. Upper contact is marked by an abrupt change in size of pumice clasts.

$0.3 \quad$ Covered interval.

1.2 Coarse, pumiceous, pyroclastic-flow deposit. Light pinkish-gray, vitric matrix. Pumice clasts (50 percent grading upward to 60-70 percent) are light gray, vitric, 10 to $40 \mathrm{~mm}$ with blocks to $120 \mathrm{~mm}$. Lithic clasts (less than 1 percent) include gray and reddish-gray devitrified volcanic rock, less than $5 \mathrm{~mm}$. Crystals ( $5-7$ percent) include feldspar and biotite.

0.5 Lenticular deposit of coarse, light-gray, vitric pumice blocks, 30 to $150 \mathrm{~mm}$, locally larger. Deposit is nonwelded, mostly clast supported. Pumice clasts have 3 to 5 percent crystals of feldspar and biotite. Unit has less than 1 percent lithic clasts. Upper contact is marked by an abrupt size change.

\section{Pre-Pah Canyon Tuff bedded tuff (Tpbt2)}

0.3 Unit D - Reddish-brown, matrix-supported deposit. Pumice clasts (15-20 percent) are light gray, vitric, 3 to $20 \mathrm{~mm}$. Lithic clasts ( $3-5$ percent) include pinkish-gray devitrified volcanic rock and very dark-gray porphyritic glass, 1 to $15 \mathrm{~mm}$. Crystals (10-12 percent) include feldspar, oxidized biotite, and pyroxene. Upper contact is sharp and undulatory.

$0.9 \quad$ Covered interval. 
$0.4 \quad$ Unit C - Poorly sorted, partially altered, pumiceous fallout deposit. Vitric pumice clasts (20-25 percent) are light gray, 5 to $15 \mathrm{~mm}$, rarely to $25 \mathrm{~mm}$. Altered pumice clasts (50 percent) are orange-brown, 10 to $25 \mathrm{~mm}$. Lithic clasts ( $3-5$ percent) include reddish-gray devitrified volcanic rock and very dark-gray porphyritic glass, 3 to $15 \mathrm{~mm}$. Crystals (2-3 percent) include feldspar and oxidized biotite.

2.9 Covered interval.

0.2 Unit B - Nonwelded, altered, poorly sorted fallout deposit. Vitric pumice clasts (15-25 percent) are light gray, 5 to $15 \mathrm{~mm}$. Altered pumice clasts $(60-70$ percent) are yellowish brown, 10 to $20 \mathrm{~mm}$. Lithic clasts (2-3 percent) include dark grayish-red devitrified volcanic rock, less than $3 \mathrm{~mm}$. Crystals (10 percent) include feldspar, oxidized biotite, and rare pyroxene.

$2.8 \quad$ Covered interval.

Topopah Spring Tuff (Tpt)

Crystal-rich vitric zone (Tptrv)

Moderately welded subzone (Tptrv2)

1.8 Moderately welded, clast-supported fallout deposit. Silicified zone from approximately $30 \mathrm{~cm}$ above base of unit to $20 \mathrm{~cm}$ below top of unit. Pumice clasts (70-80 percent) are flattened, vitric to devitrified with some vapor-phase mineralization, typically 10 to $15 \mathrm{~mm}$. Lithic clasts (3-5 percent) include pale-red and medium gray devitrified volcanic rock to $10 \mathrm{~mm}$. Crystals $(10-15$ percent $)$ include feldspar, biotite, and rare pyroxene. Vapor-phase alteration is more pronounced, and biotite is oxidized, above and below the silicified horizon.

$0.5 \quad$ Covered interval.

0.4 Light-gray pyroclastic-flow deposit, devitrified and altered. Pumice clasts (20-25 percent) are dark reddish gray, devitrified with coarse vapor-phase mineralization, to $35 \mathrm{~mm}$. Lithic clasts (3-5 percent) include reddish-gray devitrified volcanic rock, 1 to $10 \mathrm{~mm}$. Crystals (3-5 percent) include feldspar, biotite, magnetite (?).

0.3 Covered interval.

Densely welded subzone (Tptrv1)

Reddish-brown vitrophyre with black fiamme. Crystals (10-12 percent) include feldspar, oxidized biotite, and pyroxene.

\section{Base of section}

\section{Measured stratigraphic section on the eastern side of Solitario Canyon (section PTn\#8)}

Location description: East side of Solitario Canyon, the section was measured in a gully with good exposures. Section PTn\#8 is in the same location as hydrologic properties traverse SBC-1 (Rautman and others, 1995). To document rapid lateral thickness variations of the units, additional thickness measurements were made in a gully approximately $30 \mathrm{~m}$ to the north of PTn\#8 and are listed here as section PTn\#8A. PTn\#8A is in the same location as hydrologic properties traverse SB-2 (Rautman and others, 1995).

Approximate location of section PTn\#8: N760300 E557900 (Nevada state coordinate system), elevation 4,500 ft. Approximate location of section PTn\#8A: N760400 E557900 (Nevada state coordinate system), elevation $4,500 \mathrm{ft}$.

Strike and dip of bedding: $8^{\circ}, 5^{\circ} \mathrm{E}$ in Tpbt 3 unit D for PTn\#8 and $35^{\circ}, 6^{\circ} \mathrm{E}$ for PTn\#8A at base of Tpy.

Line of section: For PTn\#8, the line of section is $100^{\circ}$; dip in line of section is approximately $5^{\circ}$. The section is offset approximately $15 \mathrm{~m}$ to the south along Tpp-Tpbt 2 contact. For PTn\#8A, the line of section is $85^{\circ}$; dip in the line of section is approximately $3^{\circ}$.

112 Stratigraphic Relations and Hydrologic Properties of the Paintbrush Tuff Nonwelded (PTn) Hydrologic Unit, Yucca Mountain, Nevada 
Stratigraphic

Thickness

(meters)

\section{Top of section}

Tiva Canyon Tuff (Tpc)

\section{Crystal-poor vitric zone (Tpcpv)}

Censely welded subzone (Tpcpv3)

\section{Moderately welded subzone (Tpcpv2)}

3.1 Moderately welded pyroclastic-flow deposit. Unit is mostly covered. Orange-pink to tan matrix contains glass shards. Shards are amber to black and darken upwards. Pumice clasts, lithic clasts, and phenocrysts are similar to those described for subzone pvl. Black fiamme and strongly deformed shards in the uppermost $0.5 \mathrm{~m}$ of the unit indicate that the unit may be densely welded near the upper contact.

\section{Non- to partially welded subzone (Tpcpv1)}

3.3 Tan, non- to partially welded pyroclastic-flow deposit with possible flow break approximately $1 \mathrm{~m}$ below the top of the unit. Pumice clasts ( 20 to 25 percent) are altered, rarely vitric, mostly gray to grayish pink, and 5 to $20 \mathrm{~mm}$. Pumice clasts are slightly smaller ( 3 to $15 \mathrm{~mm}$ ) for $0.5 \mathrm{~m}$ above the flow break. Amber to black, bubble-wall glass shards are contained within a tan, ashy matrix. Lithic clasts ( 2 to 3 percent) are predominantly pale-red, gray, and brown devitrified rock, and rare black glass. Crystals of feldspar comprise 2 to 3 percent.

\section{Pre-Tiva Canyon Tuff bedded tuff (Tpbt4)}

$0.3 \quad$ Covered interval.

0.5 Unit B - Pumiceous, well-sorted fallout deposit. Deposit is massive with faint laminations in bottom 5 to $10 \mathrm{~cm}$. Pumice clasts ( 70 to 80 percent) are white to gray, vitric, and 2 to $5 \mathrm{~mm}$; some are pink and altered (argillic?). Pale-red to gray lithic clasts (20 to 25 percent) are mostly devitrified and 1 to $3 \mathrm{~mm}$. Crystals ( 2 to 5 percent) include feldspar.

\section{Yucca Mountain Tuff (Tpy)}

1.5 Pyroclastic-flow deposit grades upward from light gray to light yellowish brown with abundant, colorless, bubble-wall glass shards. The lower contact is sharp with slight undulations at the top of unit bt $3 \mathrm{G}$; the upper contact is sharp. Crystals of feldspar compose less than 1 percent. Brown to gray lithic clasts (less than 1 percent) are devitrified and smaller than $10 \mathrm{~mm}$. Pumice clasts (10 to 15 percent) are vitric, light gray, smaller than $15 \mathrm{~mm}$, and difficult to distinguish with a hand lens.

The basal 2 to $4 \mathrm{~cm}$ of the unit is a ground layer that contains angular, 5 to $15 \mathrm{~mm}$, reddish-gray devitrified lithic clasts ( 15 to 20 percent). Pumice clasts ( 15 to 20 percent) are light gray and smaller than $20 \mathrm{~mm}$. The interval pinches and swells slightly across the exposure.

The upper $30 \mathrm{~cm}$ of Tpy is brownish with 7 to 12 percent pumice clasts, up to $40 \mathrm{~mm}$. Vitric, bubblewall shards are present in the matrix. This interval contains 5 to 20 percent white pumice clasts ( 1 to $2 \mathrm{~mm}$ ), derived from overlying units, that are dispersed through the matrix or concentrated in angular chunks and pods. Lithic clasts in this interval include angular, dark-gray or brownish to colorless glass (the latter are poorly vesicular), and pink to grayish red and devitrified. Round pods (5- to 7-cm diameter) of brownish Tpy that contain Tpbt 4 pumice occur down to about $30 \mathrm{~cm}$ above the Tpy base and may represent burrows. 


\section{Pre-Yucca Mountain Tuff bedded tuff (Tpbt3)}

0.55 Unit $\mathrm{G}$ - Tan, poorly sorted fallout deposit (reworked?) with tan matrix. Slightly rounded pumice clasts ( 70 to 80 percent) are vitric, tan to gray, and 3 to $15 \mathrm{~mm}$, rarely to $50 \mathrm{~mm}$. Lithic clasts (10 to 20 percent) are dominantly gray glass with subordinate gray, brown, and pale-red devitrified volcanic rocks ( 1 to $10 \mathrm{~mm}$ ). Crystals of feldspar compose 2 to 3 (?) percent. The upper contact is sharp.

0.4 Unit F - Poorly sorted, light-tan to very light-gray fallout deposit with hints of thin bedding. Lightgray pumice clasts ( 80 to 90 percent) are vitric to slightly altered, and 2 to $20 \mathrm{~mm}$. Lithic clasts (10 to 15 percent) are dominantly gray glass with rare pale-red or gray devitrified clasts ( 2 to $10 \mathrm{~mm}$ ). Crystals of feldspar compose 2 to 3 (?) percent. Some horizons that contain 2- to 5-mm pumice clasts are moderately sorted. The upper contact is undulatory and sharp to gradational along strike.

0.25 Unit D - Moderately sorted, coarse, white to gray fallout deposit. Pumice clasts (80 to 90 percent) are white to very light gray, 10 to $30 \mathrm{~mm}$, and vitric. Gray to red devitrified lithic clasts (10 to 15 percent) contain a distinctive rusty alteration in some horizons; lithic clasts of gray glass ( 3 to $10 \mathrm{~mm}$ ) are rare. Crystals of feldspar compose 2 to 3 (?) percent. The unit is thinly bedded with a sharp upper contact.

0.6 Unit C - Poorly to moderately sorted, tan fallout deposit (reworked?). Pumice clasts (80 to 90 percent) are light gray, vitric, and typically finer grained than underlying and overlying beds, 1 to $5 \mathrm{~mm}$, but occur to $15 \mathrm{~mm}$. Lithic clasts ( 5 to 10 percent) are mostly gray, brown, and red devitrified volcanic rocks, rarely gray glass, and typically 3 to $10 \mathrm{~mm}$, but rarely to $30 \mathrm{~mm}$. Crystals of feldspar and oxidized biotite compose 2 to 3 (?) percent. A discontinuous, coarse, and pumiceous interval occurs about $5 \mathrm{~cm}$ below the top of the unit. The upper contact is sharp; the lower contact is gradational.

0.9 Unit B - Poorly sorted, orange-brown fallout deposit (reworked?). The unit is normally graded with 70 to 80 percent pumice clasts at its base, decreasing to 30 to 40 percent at its top. Pumice clasts are vitric, 2 to $20 \mathrm{~mm}$, and light gray with orange rims. Lithic clasts [5 to 10 (?) percent] are pale-red or gray devitrified volcanic rocks (smaller than $10 \mathrm{~mm}$ ), or rare gray glass. Crystals of feldspar compose 5 (?) percent. The amount of orange-brown matrix increases upward. The upper contact is gradational.

0.4 Unit A - Pumiceous, light-gray to grayish-pink fallout deposit. Matrix (10 to 15 percent) is orangepink. Gray to pinkish-gray pumice clasts (70 to 80 percent) are vitric to slightly altered, and 15 to $25 \mathrm{~mm}$. Lithic clasts ( 2 to 5 percent) are typically $5 \mathrm{~mm}$ and include pale-red devitrified volcanic rocks and gray glass. Crystals of feldspar and (rare) oxidized biotite compose 2 to 3 percent. The upper contact is gradational.

\section{Pah Canyon Tuff (Tpp)}

$00.8 \quad$ Pyroclastic-flow deposit. The lowest $20 \mathrm{~cm}$ contains coarse, clast-supported pumice blocks (up to $150 \mathrm{~mm}$ ) that overlie a locally preserved, laminated ash approximately $3 \mathrm{~cm}$ thick. Pumice clasts are vitric, frothy, and light gray with 3 to 5 percent crystals of feldspar and biotite. The unit grades upward into a pumiceous, brownish, matrix-supported deposit. Glass shards are not recognized in the matrix. Pumice clasts $(5$ to $50 \mathrm{~mm}$ ) are light gray, vitric, and frothy; clasts near the top of the formation have a brownish outer rind. Crystals of feldspar and oxidized biotite compose 5 (?) percent. Gray lithic clasts (less than 5 percent) are devitrified and smaller than $20 \mathrm{~mm}$. The upper contact is irregular. 


\section{Pre-Pah Canyon Tuff bedded tuff (Tpbt2)}

$0.45 \quad$ Unit D - Line of section is offset $15 \mathrm{~m}$ to south. Thickness of unit D increases to $1.15 \mathrm{~m}$ along offset.

Brown, poorly sorted, reworked (?) deposit contains microvesicular, light-gray pumice clasts (20 to 30 percent) which are vitric, nondeformed, and smaller than $20 \mathrm{~mm}$. Pink pumice clasts (10 to 15 percent) are smaller than $15 \mathrm{~mm}$. Crystals of feldspar and biotite compose 7 to 10 percent. Lithic clasts (10 to 15 percent) include altered, reddish clasts possibly derived from the substrate, gray and red devitrified clasts, and black porphyritic glass (smaller than $15 \mathrm{~mm}$ ). The upper and lower contacts are sharp.

3.65 Unit C - Light-gray, vitric, massive, nonwelded pumice-fall deposit. The unit is poorly sorted but clast supported. Nondeformed pumice clasts are light gray to white, smaller than $20 \mathrm{~mm}$, and vitric. Lithic clasts ( 5 percent) include reddish-gray to grayish-brown devitrified volcanic rocks, and black porphyritic glass (all are smaller than $20 \mathrm{~mm}$ ). Lithic-clast content increases to 10 to 15 percent with abundant glass in the top $1 \mathrm{~m}$. Crystals of feldspar with subordinate biotite and rare pyroxene compose 5 to 7 percent. Red, argillic alteration is well developed in upper $1 \mathrm{~m}$ of unit. The upper contact is sharp; the lower contact grades over approximately $30 \mathrm{~cm}$ based on color change.

1.2 Unit B - Altered, brownish, nonwelded pumice-fall deposit. The unit is poorly sorted. Ash layer 1, which occurs $25 \mathrm{~cm}$ above the base of the unit, is continuous over the length of the exposure. Ash layer 1 is a pink ash overlain by a thin layer of devitrified and glassy lithic clasts. The abundance of glassy lithic clasts within unit B increases sharply above the ash layer. Gray pumice clasts have distinct margins, whereas predominant brownish-yellow pumice clasts have indistinct margins. Lithic clasts (10 to 20 percent) include red and gray devitrified volcanic rocks, brown and black porphyritic glass, and rare red tuff. Lithic clasts typically are 3 to $20 \mathrm{~mm}$, but occur to $40 \mathrm{~mm}$. Crystals of feldspar with rare, oxidized biotite, and pyroxene compose 5 to 7 percent.

\section{Topopah Spring Tuff (Tpt)}

Crystal-rich vitric zone (Tptrv)

Non- to partially welded subzone (Tptrv3) [Tpbt2A]

1.2 Crudely layered, non- to partially welded, pumice-fall deposit. The unit is poorly sorted. Gray and brown, vitric pumice clasts (mostly smaller than $25 \mathrm{~mm}$, but to $120 \mathrm{~mm}$ ) are non- to partially deformed. The percentage of brown clasts increases upward. Lithic clasts (10 to 15 percent) are mostly red and gray devitrified volcanic rocks with rare, black porphyritic glass; clasts of red, altered tuff occur near the top of the unit. Crystals ( 5 to 10 percent) include predominant feldspar with rare oxidized biotite and rare pyroxene. Gray pumice clasts are altered to pink near top of unit. The upper contact grades over approximately $50 \mathrm{~cm}$.

\section{Moderately welded subzone (Tptrv2) [Tpbt2A]}

1.3 Moderately welded pumice-fall deposit. The unit is poorly sorted with vitric, gray to brown, deformed pumice clasts. Pumice clasts typically are smaller than $20 \mathrm{~mm}$ (long axis), but occur to $5 \times 40 \mathrm{~mm}$. Lithic clasts ( 5 to 10 percent) are red to gray devitrified volcanic rocks ( 3 to $30 \mathrm{~mm}$ ). Crystals (less than 5 percent) include feldspar and subordinate oxidized biotite. Pumice clasts in the top $50 \mathrm{~cm}$ of the unit are corroded and replaced by vapor-phase minerals; the matrix appears silicified. The upper contact (defined by welding) grades over approximately $50 \mathrm{~cm}$; lower contact sharp.

\section{Densely welded subzone (Tptrv1)}

Densely welded pyroclastic-flow deposit. The unit is a reddish-brown glass with black fiamme. Welded pumice blocks are brown to black, and highly elongate with long axes to $200 \mathrm{~mm}$. Crystals of feldspar, rare biotite, and rare pyroxene compose 12 to 15 percent. Upper contact is sharp.

\section{Base of section}




\section{Section PTN\#8A - Unit thicknesses approximately $\mathbf{3 0}$ meters north of Section PTn\#8}

Stratigraphic

Thickness

(meters)

Top of section

Tiva Canyon Tuff (Tpe)

Crustal-poor vitric zone (Tpcpv)

3.7 Moderately welded subzone (Tpcpv2)

$2.4 \quad$ Non-to partially welded subzone (Tpcpv1)

Pre-Tiva Canyon Tuff bedded tuff (Tpbt4)

$0.9 \quad$ Unit B

1.5 Yucca Mountain Tuff (Tpy)

Pre-Yucca Mountain Tuff bedded tuff (Tpbt3)

$0.35 \quad$ Unit $\mathrm{G}$

0.3 Unit $F$

$0.35 \quad$ Unit D

$0.3 \quad$ Unit C

$0.6 \quad$ Unit B - Unit is partially covered.

0.2 Covered interval.

0.7 Pah Canyon Tuff (Tpp)

Pre-Pah Canyon Tuff bedded tuff (Tpbt2) - Ash layers 1 and 2 were not found.

$0.2 \quad$ Unit $\mathrm{D}$

$4.8 \quad$ Unit $\mathrm{C}$

$1.5 \quad$ Unit B

Unit A - See below

Topopah Spring Tuff (Tpt)

Crystal-rich vitric zone (Tptrv)

$0.2 \quad$ Non- to partially welded subzone (Tptrv3) [Tpbt2A]

$0.35 \quad$ Covered Interval

$0.35 \quad$ Moderately welded subzone (Tptrv2) [Tpbt2A]

0.7 Covered Interval

Densely welded subzone (Tptrvl)

Base of section

116 Stratigraphic Relations and Hydrologic Properties of the Paintbrush Tuff Nonwelded (PTn) Hydrologic Unit, Yucca Mountain, Nevada 


\section{Measured stratigraphic section on the eastern side of Solitario Canyon (section PTn\#9)}

Location description: East side of Solitario Canyon, section was measured in gully with good exposures. The section is in the same location as hydrologic properties traverse SB-6 (Rautman and others, 1995).

Approximate location of top of section: N760700 E557600 (Nevada state coordinate system), elevation $4,500 \mathrm{ft}$.

Strike and dip of bedding: $29^{\circ}, 6^{\circ}(\mathrm{E})$ on laminations in the base of Tpbt4 unit B.

Line of section: $112^{\circ}$, dip in line of section is approximately $5.5^{\circ}$.

Note: The unit descriptions listed below are abbreviated. Full unit descriptions can be found in measured sections PTn\#1-PTn\#6.

Stratigraphic

Thickness

(meters)

Top of section

Tiva Canyon Tuff (Tpc)

Crystal-poor vitric zone (Tpcpv)

Densely welded subzone (Tpcpv3)

Approximately $80-\mathrm{cm}$-thick, densely welded pyroclastic-flow deposit with preserved vitroclastic texture.

Moderately welded subzone (Tpcpv2)

3.0 Tan to orange, moderately welded pyroclastic-flow deposit. Unit becomes densely welded at upper contact. Upper contact is gradational.

Non- to partially welded subzone (Tpcpv1)

3.1 Tan, non- to partially welded pyroclastic-flow deposit. Scattered, very large (up to $7 \times 16 \mathrm{~cm}$ ) pumice clasts near base of unit. Upper contact is gradational.

\section{Pre-Tiva Canyon Tuff bedded tuff (Tpbt4)}

1.7 Unit B - Pumiceous fallout deposit, light gray to pinkish gray at top. Pumice clasts are 1 to $3 \mathrm{~mm}$. Bottom 5 to $10 \mathrm{~cm}$ of unit contains horizontal laminations that may represent a pyroclastic-surge deposit. A $50-\mathrm{cm}$-thick interval in the middle of unit contains faint horizontal to cross (?) laminations. Upper contact is sharp.

\section{Yucca Mountain Tuff (Tpy)}

0.8 Basal ground layer overlain by approximately $30 \mathrm{~cm}$ of light-tan, non-welded pyroclastic-flow deposit. The upper part of the unit is tan-brown, appears disturbed, and contains burrow (?) structures. The upper part of the unit also contains scattered large (few centimeters) lithic clasts, some of poorly vesiculated glass. Upper contact is sharp.

\section{Pre-Yucca Mountain Tuff bedded tuff (Tpbt3)}

0.6 Unit G - Poorly sorted, tan, pumiceous, reworked (?) fallout deposit. Upper contact is sharp.

0.25 Unit F - Fine to coarse, poorly to moderately sorted, pumiceous fallout deposit. Unit contains distinctive lithic clasts of gray glass. Upper contact is sharp and undulatory.

0.4 Unit D - Coarse, pumiceous, moderately to well-sorted fallout deposit with distinctive lithic clasts of devitrified volcanic rock that locally show rusty alteration. Upper contact is sharp. 
0.45 Unit C - Tan, moderately to poorly sorted, reworked (?) fallout deposit. Pumice clasts are 1 to $5 \mathrm{~mm}$. Upper contact is sharp.

0.95 Unit B - Normally graded, poorly sorted, orange-brown, reworked (?) fallout deposit. Pumice clasts decrease in abundance upward and are 1 to $15 \mathrm{~mm}$. Unit is cut by several small faults with approximately $10 \mathrm{~cm}$ of displacement. Upper contact is gradational over approximately $5 \mathrm{~cm}$.

0.75 Unit A - Moderately to well-sorted, pumiceous fallout deposit, white to orange-brown at top. Upper contact is poorly exposed.

\section{Pah Canyon Tuff (Tpp)}

1.1 Pyroclastic-flow deposit. Unit is matrix supported with scattered large pumice clasts. Light-gray pumice clasts, many with reddish-brown rinds, compose 25 to 35 percent of the unit and have diameters to $13 \mathrm{~cm}$. Matrix is sandy; glass shards are not observed. Lithic clasts ( 2 to 3 percent) include red and gray devitrified volcanic rocks smaller than $15 \mathrm{~mm}$. Crystals ( 7 to 10 percent) include feldspar and biotite. Lithic-clast and crystal content increases in the basal $10 \mathrm{~cm}$ of unit (to 10 to 15 percent each). The upper contact is sharp and irregular.

\section{Pre-Pah Canyon Tuff bedded tuff (Tpbt2)}

5.1 Unit C - Light-gray, massive, clast-supported fallout deposit with vitric pumice clasts. Lithic clasts include abundant black, gray, and brown glassy clasts and red, pink, and gray devitrified volcanic rock. The unit is poorly sorted. Ash layer $2,2 \mathrm{~cm}$ thick with pink ash and glassy lithic clasts, is poorly exposed and located approximately $1.1 \mathrm{~m}$ above base of unit. Poorly developed red alteration is present in the upper meter of unit. Upper contact is sharp.

1.9 Unit B - Nonwelded, clast-supported fallout deposit. Silicified or vapor-phase (?) corroded zone, $15 \mathrm{~cm}$ thick, located approximately $0.85 \mathrm{~m}$ above base of unit. Pumice clasts are brown, some light gray, and altered (?). Corroded pumice clasts have microscopic vapor-phase crystals. Lithic clasts are predominantly reddish gray and devitrified; hypabyssal (?) clast found approximately $10 \mathrm{~cm}$ above basal contact. Crystals include feldspar, bronze (altered) biotite, and rare pyroxene. This unit is poorly sorted. Upper contact is gradational over approximately $30 \mathrm{~cm}$.

\section{Topopah Spring Tuff (Tpt)}

Crystal-rich vitric zone (Tptrv)

Non- to partially welded subzone (Tptrv3)

1.8 Unit A - Nonwelded fallout deposit. Porous, non- to slightly deformed, vitric pumice clasts, dominantly gray with lesser brown. The unit is moderately to poorly sorted. Upper contact is gradational over approximately $20 \mathrm{~cm}$.

\section{Moderately welded subzone (Tptrv2)}

$0.4 \quad$ Covered interval.

0.1 Moderately welded, gray fallout deposit with deformed, vitric pumice clasts, minor porosity.

0.6 Covered interval.

Densely welded subzone (Tptrvl)

Brownish-red, crystal-rich vitrophyre.

\section{Base of section}

118 Stratigraphic Relations and Hydrologic Properties of the Paintbrush Tuff Nonwelded (PTn) Hydrologic Unit, Yucca Mountain, Nevada 


\section{Measured stratigraphic section on the eastern side of Abandoned Wash (section PTn\#10)}

Location description: East side of Abandoned Wash across from the first prominent east-trending wash, south of the neutron borehole complex, the section was measured on an outcrop with good exposures.

Approximate location of section: N754150 E560500 (Nevada state coordinate system), elevation 4,340 ft at top of section.

Strike and dip of bedding: $344^{\circ}, 7^{\circ}(\mathrm{E})$ on parting in Tpbt 3 unit D.

Line of section: Lower part of section: $95^{\circ}$, dip in line of section is approximately $5.5^{\circ}$. Upper part of section: $85^{\circ}$, dip in line of section is approximately $6^{\circ}$.

Note: The section was measured from the top of Tptrv1 to the Tpbt2-Tpbt 3 contact, then offset approximately $20 \mathrm{~m}$ southward along this contact. The Tpbt $2 \mathrm{C}-\mathrm{bt} 2 \mathrm{D}$ contact is covered at the northern location, but was excavated at the southern location. The thickness of Tpbt2 unit D was measured down from the Tpbt2-Tpbt 3 contact at the southern location and its thickness computed into the section. The section was also offset a few meters northward along the Tpbt3 unit B-unit $\mathrm{C}$ contact; the line of section did not change at this offset.

The unit descriptions listed below are abbreviated. Full unit descriptions can be found in measured sections PTn\#1-PTn\#6.

Stratigraphic

Thickness

(meters)

Top of section

Tiva Canyon Tuff (Tpc)

Crystal-poor lower nonlithophysal zone (Tpcpln)

Columnar subzone (Tpcplnc)

Crystal-poor vitric zone (Tpcpv)

Moderately welded subzone (Tpcpv2)

$1.8 \quad$ Moderately welded pyroclastic-flow deposit. Brownish-orange, vitric matrix contains abundant deformed amber glass shards. The unit is poorly exposed but appears moderately welded at the upper contact where the rock becomes devitrified. Upper contact is poorly exposed.

$2.3 \quad$ Covered interval.

Non- to partially welded subzone (Tpcpv1)

2.95 Non- to partially welded pyroclastic-flow deposit. Brownish-orange-yellow, vitric matrix contains abundant, nondeformed, amber glass shards. Pumice clasts (10 to 15 percent) are vitric and smaller than $15 \mathrm{~mm}$. Lithic clasts ( 3 to 5 percent) include gray to red devitrified volcanic rock (smaller than $5 \mathrm{~mm}$ ), gray glass (rare) and brown, moderately welded, vitric tuff (to $25 \mathrm{~mm}$ ). Basal $10 \mathrm{~cm}$ is a well-developed, coarse ground layer. Upper contact is covered.

\section{Pre-Tiva Canyon Tuff bedded tuff (Tpbt4)}

0.5 Unit B - Pumice-fall deposit. Well-sorted, white to light-gray pumice with a pink (paleosol) at top. Massive with faint laminations in the lowest $5 \mathrm{~cm}$ of unit. Upper contact is sharp.

\section{Pre-Yucca Mountain Tuff bedded tuff (Tpbt3)}

0.4 Unit G - Reworked (?) fall deposit. Poorly sorted, brown, clast-supported deposit. Upper $15 \mathrm{~cm}$ is very disturbed with lenticular structures and burrows (?) filled with pumice from the overlying unit. Upper contact is sharp to disturbed and gradational. 
0.25 Unit F - Pumice- and lithic-fall deposit. Tan to gray, poorly to moderately sorted, thinly bedded to laminated deposit. Unit is composed of vitric pumice and distinctive lithic clasts of gray glass. Upper contact grades over 10 to $15 \mathrm{~cm}$.

0.55 Unit D - Pumice- and lithic-fall deposit. Moderately sorted, thinly bedded deposit. Light-gray, vitric pumice clasts ( 70 to 80 percent) are typically 3 to $10 \mathrm{~mm}$. Distinctive lithic clasts of gray to red devitrified volcanic rock locally have rusty alteration. Upper contact is sharp.

0.35 Unit C - Possibly reworked fall deposit. Moderately sorted deposit that grades upward from brownish gray to brown and that contains pumice clasts of 1 to $3 \mathrm{~mm}$. Middle of unit has a discontinuous, 5 - $\mathrm{cm}$-thick pumice- and lithic-rich layer with pumice clasts to $20 \mathrm{~mm}$. Top of unit appears weathered or reworked; upper contact is sharp.

\section{SECTION IS OFFSET APPROXIMATELY 5 METERS NORTHWARD}

0.85 Unit B - Reworked (?) fall deposit. Normally graded, poorly sorted, orange-brown deposit is poorly exposed except in the upper $30 \mathrm{~cm}$. Light-gray, vitric to altered pumice clasts decrease in abundance upward and are 3 to $15 \mathrm{~mm}$. Top of unit has round burrow (?) structures filled with material from the overlying unit. Upper contact is gradational over approximately $10 \mathrm{~cm}$ and appears locally disturbed.

0.45 Unit A - Nonwelded pumice-fall deposit. White to light-gray, vitric to slightly altered pumice clasts ( 90 percent), typically 5 to $15 \mathrm{~mm}$. Crystals ( 5 to 10 percent) of feldspar and bronze biotite. Upper contact grades over approximately $20 \mathrm{~cm}$.

\section{SECTION IS OFFSET APPROXIMATELY 20 METERS SOUTHWARD}

\section{Pre-Pah Canyon Tuff bedded tuff (Tpbt2)}

0.85 Unit D - Reworked (?) deposit. Pinkish-brown, matrix-supported, poorly sorted deposit with a fine sandy matrix. Unit contains light-gray to pinkish-gray pumice clasts with orange weathering rind (15 to 25 percent; 1 to $10 \mathrm{~mm}$ ), lithic clasts ( 3 to 5 percent) of gray and brown devitrified volcanic rock, and crystals of feldspar, oxidized biotite, and possible pyroxene ( 7 to 10 percent). Unit is poorly exposed; upper contact is sharp.

5.35 Unit C - Nonwelded pumice-fall deposit. Light gray to buff, massive to crudely layered in upper $3 \mathrm{~m}$, clast-supported deposit. Nondeformed, vitric pumice clasts are light gray, typically 5 to $20 \mathrm{~mm}$ (up to $50 \mathrm{~mm}$ ). Lithic clasts (5 to 10 percent) of black porphyritic glass and red and gray devitrified volcanic rock ( 3 to $10 \mathrm{~mm}$ ); crystals ( 7 to 10 percent) of feldspar, biotite, and rare pyroxene. The unit is poorly sorted. Weakly developed red alteration is present in the poorly exposed upper meter of unit. Upper contact was excavated from hillside.

1.7 Unit B - Nonwelded pumice-fall deposit. Poorly sorted, moderate brown deposit with clasts of moderate brown and light-gray, vitric to altered (?), nondeformed pumice ( 5 to $25 \mathrm{~mm}$ ). Lithic clasts ( 5 to 10 percent) of red to gray devitrified volcanic rock typically smaller than $7 \mathrm{~mm}$. Crystals of feldspar, biotite, and rare pyroxene ( 5 to 7 percent). Upper contact is gradational over approximately $30 \mathrm{~cm}$. Ash layer 1 occurs at the upper contact. It is a $1-\mathrm{cm}$-thick layer of reddish ash overlain by a millimeter-thick layer of devitrified lithic clasts. Layer eroded from along bedding parting; layer was excavated from hillside.

\section{Topopah Spring Tuff (Tpt)}

Crystal-rich vitric zone (Tptrv)

Non- to partially welded subzone (Tptrv3) 
Unit A - Non- to partially welded pumice-fall deposit. Clast-supported, pinkish-gray/brown, nondeformed, vitric pumice typically 5 to $15 \mathrm{~mm}$ (up to $40 \mathrm{~mm}$ ). Crystals of feldspar and subordinate biotite compose 2 to 4 percent; lithic clasts ( 5 to 10 percent) of gray and red devitrified volcanic rock. Unit becomes less welded upward and has abundant intragranular porosity. Upper contact is gradational over approximately $50 \mathrm{~cm}$.

\section{Moderately welded subzone (Tptrv2)}

$0.1 \quad$ Moderately welded pumice-fall deposit. Clast supported with deformed, vitric, pinkish-gray/brown pumice clasts typically 10 to $15 \mathrm{~mm}$. Crystals of feldspar compose 2 to 3 percent; lithic clasts of devitrified lava. Unit has minor porosity. Upper contact grades over approximately $20 \mathrm{~cm}$.

0.45 Covered interval.

0.0 Densely welded subzone (TptrvI)

Densely welded pyroclastic-flow deposit. Black to reddish-brown, crystal-rich vitrophyre with black to brownish-red fiamme. Grades upward into pinkish-gray glass with large (to $200 \mathrm{~mm}$ ), reddishbrown, crystal-rich fiamme. Upper contact not exposed.

\section{Base of section}

\section{Measured stratigraphic section on the eastern side of Solitario Canyon (section PTn\#11)}

Location description: Section was measured in gully on east side of Solitario Canyon with excellent exposures and interesting bedding geometries near the top of the PTn unit. The section is in the same location as hydrologic properties traverse SB-12 (Rautman and others, 1995).

Approximate location of section: N761100 E557700 (Nevada state coordinate system), elevation 4,560 ft at top of section.

Strike and dip of bedding: $4^{\circ}, 8^{\circ}(\mathrm{E})$ are average values taken from four measurements.

Line of section: $95^{\circ}$, dip in line of section is approximately $8^{\circ}$.

Note: Unit thicknesses from the base of the section to the top of Tpbt3 unit B were measured using a Jacob's staff. Units $T p b t 3$ unit $C$ to unit $G$ were measured with a meter tape at optimal locations on the outcrop. Tpy and Tpbt4 unit B were measured using a Jacob's staff at both the north and south end of the outcrop to document lateral variability. Unit thicknesses in Tpcpv were measured using a Jacob's staff.

Note: The unit descriptions listed below are abbreviated. Full unit descriptions can be found in measured sections PTn\#1-PTn\#6.

\section{Stratigraphic}

Thickness

(meters)

Tiva Canyon Tuff (Tpe)

Top of section

Crystal-poor lower nonlithophysal zone

Columnar subzone (Tpcplnc)

Crystal-poor vitric zone (Tpcpv)

Moderately welded subzone (Tpcpv2)

4.5 Yellow to orange-tan, moderately welded pyroclastic-flow deposit. Welding increases upward and unit is densely welded at the upper contact. Lithic and pumice clasts as below. 


\section{Non- to partially welded subzone (Tpcpv1)}

2.1 Yellow-brown, non- to partially welded pyroclastic-flow deposit. Matrix contains abundant amber glass shards. Basal $15-20 \mathrm{~cm}$ is a ground layer with 50-60 percent pumice clasts, up to $60 \mathrm{~mm}$. Above the ground layer, pumice clasts (15-30 percent) are gray to grayish pink and altered or grayish yellow and vitric, $2-15 \mathrm{~mm}$. Lithic clasts (2-3 percent) are dark reddish gray or brown and devitrified.

\section{Pre-Tiva Canyon Tuff bedded tuff (Tpbt4)}

0.75-1.75 Unit B - Light-gray pumiceous deposit. Pumice clasts (90-95 percent) are typically white to light gray, $1-3 \mathrm{~mm}$, and vitric. Basal $5-10 \mathrm{~cm}$ of the unit is laminated (surge deposit?). Laminae pinch and swell around blocks of Tpy. Coarser pumice clasts $(2-10 \mathrm{~mm})$ are found behind blocks of Tpy and may represent deposition in "eddies." Above the laminated horizon is $50-60 \mathrm{~cm}$ of massive fallout deposit. On the north side of the outcrop, where the unit is thinner, there are a few faint horizontal laminae in the middle of the fallout deposit, and the top of the unit is marked by a pink paleosol (?). On the south side of the outcrop, where the unit is thicker, the fallout deposit is overlain by approximately $75 \mathrm{~cm}$ of cross-laminated tuff (eolian deposit?); cross laminae are oriented $40^{\circ}, 35^{\circ}(\mathrm{E})$. Cross laminae appear to pinch and swell. Overlying the cross laminae is $20-40 \mathrm{~cm}$ of massive tuff with a pink paleosol (?). See figure 6 in text.

\section{Yucca Mountain Tuff (Tpy) and the post - Tpy interval}

1.25-0.2 This interval consists of the primary pyroclastic-flow deposit of Tpy, which pinches out on the north side of the outcrop, and a brown tuff above Tpy that is continuous across the outcrop. Tpy appears to be brecciated on the north side of the outcrop, with fill of the brown tuff around angular clasts of Tpy. On the south side of the outcrop, blocks of Tpy (up to $20 \times 70 \mathrm{~cm}$ ), eroded from the pyroclasticflow deposit, are contained in the brown tuff, at the contact between the brown tuff and overlying Tpbt4B, and within the base of Tpbt4 unit B. The brown tuff also truncates underlying units Tpbt3 unit $D, F$, and $G$. See figure 6 in text.

Tpy is a yellow-brown pyroclastic-flow deposit with abundant glass shards and minor amounts of pumice and lithic clasts. The post-Tpy brown tuff contains 5-20 percent pumice clasts that are light gray or tan, some with brown rims, 1-20 mm. Lithic clasts in the brown tuff (10-25 percent) include gray to red devitrified volcanics, red altered tuff with bronze biotite, perlitic glass, debris from bt $3 \mathrm{G}$, tan-gray and pinkish-gray, poorly vesiculated glass, and colorless glass; $10-50 \mathrm{~mm}$.

\section{Pre-Yucca Mountain Tuff bedded tuff (Tpbt3)}

0.35 Unit G - Reworked (?), brown, poorly sorted fallout deposit. Pumice clasts (70-80 percent) are gray or pinkish gray, many with tan rims, $2-20 \mathrm{~mm}$. Upper contact is locally erosional.

0.3 Unit F - Gray to tan, poorly sorted fallout deposit with faint bedding. Lithic clasts (20-30 percent) include dominant distinctive gray glass. Pumice clasts (70-80 percent) are vitric, light gray, locally with tan rims. The upper contact grades over approximately $10 \mathrm{~cm}$ and is locally erosional.

$0.4 \quad$ Unit D - Light-gray, moderately to poorly sorted fallout deposit. Unit is thinly bedded. Lithic clasts (15-20 percent) are dominantly dark-red, gray, and brown devitrified volcanic clasts, less than $10 \mathrm{~mm}$; locally, clasts have distinctive rust-colored alteration. Upper contact is sharp and locally erosional.

0.45 Unit C - Reworked (?), tan, pumiceous, moderately sorted fallout deposit. Pumice clasts (80-90 percent) are light gray and vitric, $1-3 \mathrm{~mm}$, up to $15 \mathrm{~mm}$. Upper contact is sharp.

0.5 Unit B - Reworked (?), orange-brown, poorly sorted fallout deposit. Unit is poorly exposed. Pumice clasts (25-30 percent) are light gray with orange-brown rims and are vitric. Lithic clasts (3-5 percent) are typically devitrified, dark red or gray, and less than $5 \mathrm{~mm}$. Upper contact is gradational over $10-15 \mathrm{~cm}$.

1.2 Covered interval. 


\section{Pah Canyon Tuff (Tpp)}

1.35 Light-gray pyroclastic-flow deposit, massive with crude reverse grading (?). Matrix is light gray, granular, and vitric (?). Pumice clasts at the base are $5-30 \mathrm{~mm}$ and light gray with rare crystals.

Pumice clasts at the top of the unit are 5-200 mm, many greater than $50 \mathrm{~mm}$, with crystal "clots" of feldspar and biotite. Crystals (7-10 percent) include feldspar and rare oxidized biotite. Lithic clasts (2-3 percent) are red, devitrified, and less than $5 \mathrm{~mm}$. Upper contact is not exposed.

\section{Pre-Pah Canyon Tuff bedded tuff (Tpbt2)}

0.55 Unit D - Poorly sorted, matrix-supported tuff with an orange-brown, granular, vitric (?) matrix. Pumice clasts (20-30 percent) are light gray, $3-30 \mathrm{~mm}$, and vitric. Lithic clasts (2-4 percent) are dominantly gray and devitrified, with rare black glass, $3-7 \mathrm{~mm}$. Crystals $(5-7$ percent) include feldspar, lesser biotite, and rare pyroxene.

1.25 Unit C - Poorly sorted, altered, clast-supported fallout deposit. Pumice clasts are brownish yellow, 5-50 $\mathrm{mm}$, and subangular. Lithic clasts (5-10 percent) include abundant black porphyritic glass, 5-60 $\mathrm{mm}$, and smaller (5-20 mm) pink and white devitrified volcanics. Pinkish stains and alteration occur along clast boundaries. Crystals (5-7 percent) include predominantly feldspar and lesser oxidized biotite. The upper meter of the unit is coarse with crude bedding; though reddish, it does not appear to contain clays. Upper contact is sharp and relatively flat .

1.6 Covered interval.

$0.3 \quad$ Unit $\mathrm{C}$ - See description above

1.2 Unit B (?) - Orange-brown fallout deposit. Abundant light-gray pumice clasts. Lithic clasts (2-4 percent) are dominantly gray to red and devitrified, rare black glass, less than $15 \mathrm{~mm}$. Crystals (7-10 percent) include feldspar, lesser oxidized biotite, and rare pyroxene. Upper contact is indistinct.

$1.5 \quad$ Covered interval.

\section{Topopah Spring Tuff (Tpt)}

Crystal-rich vitric zone (Tptrv)

Non- to partially welded subzone (Tptrv3) and bt2-Unit B

2.7 Unit B - Poorly exposed, moderate red to orange-brown, intensely altered fallout deposit. Alteration locally obliterates pumice-clast textures. Crystals ( $5-10$ percent) include unaltered feldspar and pyroxene, and oxy-biotite. Local silicified horizons weather into ledges about $30 \mathrm{~cm}$ thick. Reddishbrown, "cherty" float may indicate an ash layer.

\section{Moderately welded subzone (Tptrv2) and bt2-Unit A}

$1.1 \quad$ Covered interval.

0.2 Unit A - Clast-supported fallout deposit. Vitric pumice clasts are slightly deformed, less than $15 \mathrm{~mm}$, and predominantly gray and brown. Lithic clasts (2-4 percent) are all less than $5 \mathrm{~mm}$, red, gray, or pink and devitrified, with rare black or brown glass. Crystals (1-2 percent) include feldspar. Intragranular porosity is present.

$1.0 \quad$ Covered interval.

\section{Densely welded subzone (TptrvI)}

Black to reddish-brown, densely welded vitrophyre. Black and brown fiamme (12-15 percent) are up to $40 \mathrm{~mm}$. Crystals include dominant feldspar and rare oxidized biotite and pyroxene. Top of unit is covered.

\section{Base of section}


Appendix 3-Depth to Lithostratigraphic Contacts in Boreholes at Yucca Mountain, Nevada

124 Stratigraphic Relations and Hydrologic Properties of the Paintbrush Tuff Nonwelded (PTn) Hydrologic Unit, Yucca Mountain, Nevada 
Depths to lithostratigraphic contacts in the Paintbrush Tuff nonwelded hydrologic unit at Yucca Mountain, Nevada

[Depth values in meters were converted from original measurements in feet]

\begin{tabular}{|c|c|c|c|c|c|c|c|}
\hline & \multicolumn{7}{|c|}{ Borehole designation } \\
\hline & $\begin{array}{c}\text { USW } \\
\text { UZ-N11 }\end{array}$ & $\begin{array}{l}\text { USW } \\
G-2\end{array}$ & $\begin{array}{c}\text { USW } \\
\text { UZ-14 }\end{array}$ & $\begin{array}{c}\text { USW } \\
\text { NRG-7/7A }\end{array}$ & $\begin{array}{l}\text { USW } \\
\text { SD-9 }\end{array}$ & $\begin{array}{c}\text { UE-25 } \\
\text { a\#4 }\end{array}$ & $\begin{array}{c}\text { USW } \\
\text { UZ-N37 }\end{array}$ \\
\hline \multicolumn{8}{|l|}{ Tiva Canyon Tuff (Tpc) } \\
\hline \multicolumn{8}{|l|}{ Tpcplnc } \\
\hline densely welded & $4.9 \pm 0.3$ & $\mathrm{NC}$ & $* *$ & $20.1 \pm 0.3$ & $\mathrm{NC}$ & $\mathrm{NC}$ & $32.0 \pm 0.6$ \\
\hline moderately welded & $7.7 \pm 0.2$ & $\mathrm{NC}$ & $* *$ & $21.4 \pm 0.3$ & 17.4 & $<36.9$ & 33.3 \\
\hline Tpcpv2 & 9.1 & NC & $* *$ & $24.1 \pm 0.2$ & $18.6 \pm 0.3$ & 41.1 & $36.9 \pm 0.2$ \\
\hline Tpcpv1 & 14.1 & $\mathrm{NC}$ & $* *$ & $31.3 \mathrm{v}$ & 28.2 & 45.9 & 38.9 \\
\hline \multicolumn{8}{|l|}{ Tpbt4 } \\
\hline unit B & 18.5 & $\mathrm{NC}$ & $* *$ & $32.4 \mathrm{v}$ & $29.2 \mathrm{v}$ & 46.5 & $39.6 \pm 0.05$ \\
\hline unit $\mathrm{A}$ & $\mathrm{NP}$ & $\mathrm{NC}$ & $* *$ & $\mathrm{NP}$ & NP & $47.0 \pm 0.2$ & $>40.4$ \\
\hline Tpy & total depth & 103.9 & 23.8 & $48.2 \pm 0.6$ & 42.9 & 54.6 & NR \\
\hline \multicolumn{8}{|l|}{ Tpbt3 } \\
\hline unit $\mathrm{G}$ & & 104.5 & 25.0 & 48.9 & 43.6 & NR & NR \\
\hline unit $F$ & & 104.7 & 25.7 & 49.6 & $>43.8$ & NR & NR \\
\hline unit $\mathrm{E}$ & & 148.7 & 27.7 & 49.65 & NRada & NR & NR \\
\hline unit D & & $148.8 \pm 0.05$ & 28.2 & $50.5 \mathrm{v}$ & NR & NR & NR \\
\hline unit $C$ & & 150.0 & 29.0 & 51.1 & 46.1 & NR & $41.9 \pm 0.5$ \\
\hline unit B & & $\mathrm{NP}$ & 30.4 & $52.6 \pm 0.1$ & $47.3 \mathrm{v}$ & NR & $>44.0$ \\
\hline unit $A$ & & 150.6 & 31.1 & $53.7 v$ & 47.7 & 58.2 & NR \\
\hline Tpp & & 222.7 & $73.3 \mathrm{v}$ & $78.9 v$ & $69.1 \pm 0.2$ & 83.4 & 66.9 \\
\hline \multicolumn{8}{|l|}{ Tpbt2 } \\
\hline unit D & & 224.0 & 74.3 & 80.2 & 70.4 & $84,7 ?$ & 68.5 \\
\hline unit $C$ & & 230.0 & $80.7 v$ & $82.1 ?$ & $77.1 \mathrm{v}$ & $90.2 \pm 0.1$ & 73.4 \\
\hline ash layer \#2 & & 227.3 & 78.8 & $?$ & $74.9 v$ & $88.8 \pm 0.1$ & $71.8 \pm 0.05$ \\
\hline unit B & & $231.3 \pm 0.1$ & $83.4 a$ & $88.1 \pm 0.1$ & 79.5 & $94.5 ?$ & $75.5 \pm 0.1$ \\
\hline ash layer \#1 & & 230.2 & NR & $86.7 v$ & 77.9 & 92.0 & 74.6 \\
\hline \multicolumn{8}{|l|}{ Topopah Spring Tuff (Tpt) } \\
\hline unit $\mathrm{A} \rrbracket$ & & 233.8 & $85.9 v$ & $90.3 v$ & 81.8 & 96.6 & 78.2 \\
\hline non/partially welded (Tptrv3) & & 232.2 & NR & $89.2 \pm 0.1$ & 81.3 & NR & 76.4 \\
\hline moderately welded (Tptrv2) & & 233.8 & $85.9 \mathrm{v}$ & $90.3 v$ & 81.8 & 96.6 & 78.2 \\
\hline
\end{tabular}




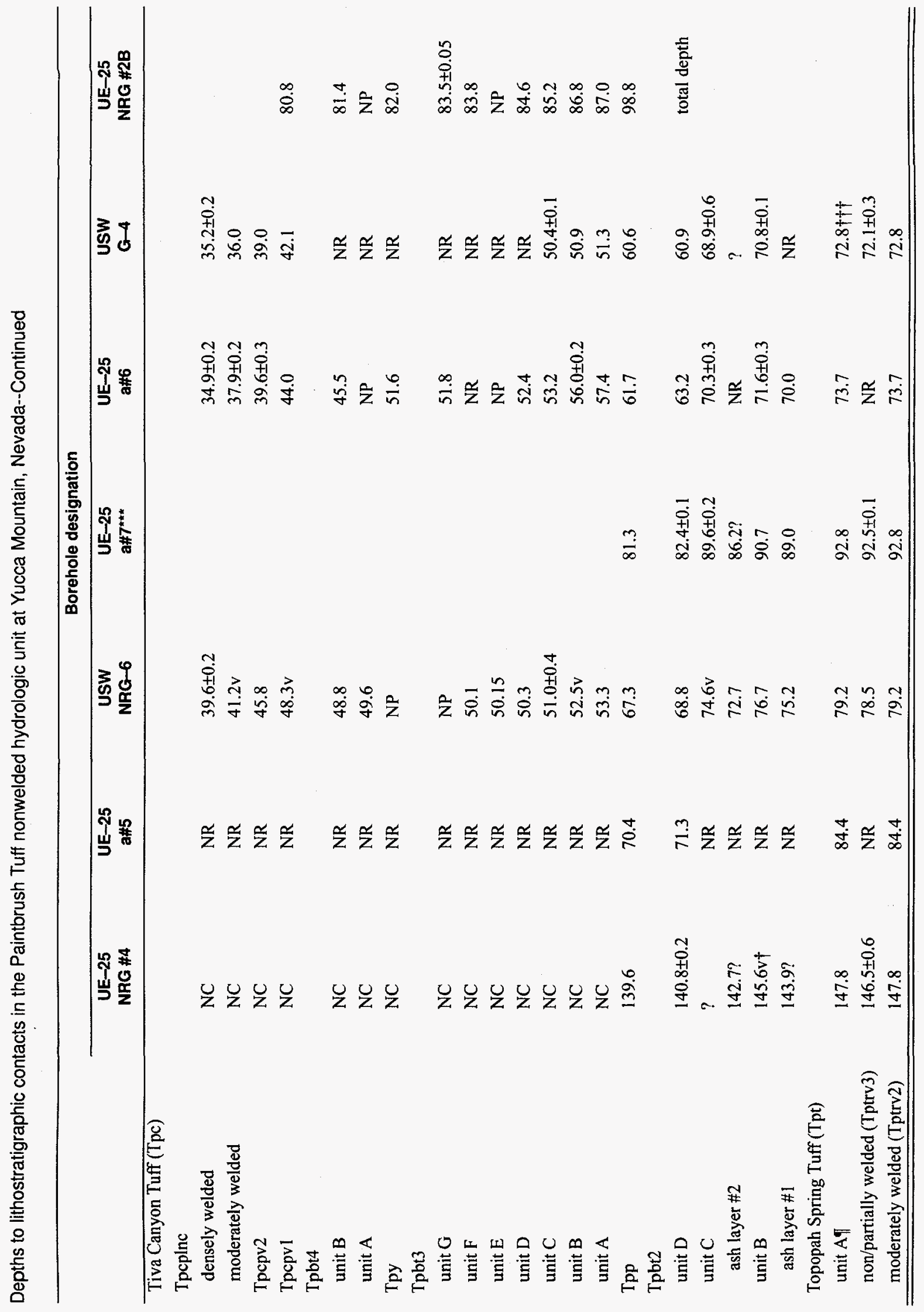

126 Stratigraphic Relations and Hydrologic Properties of the Paintbrush Tuff Nonwelded (PTn) Hydrologic Unit, Yucca Mountain, Nevada 
Depths to lithostratigraphic contacts in the Paintbrush Tuff nonwelded hydrologic unit at Yucca Mountain, Nevada--Continued

\begin{tabular}{|c|c|c|c|c|c|c|c|}
\hline & \multicolumn{7}{|c|}{ Borehole designation } \\
\hline & $\begin{array}{c}\text { UE-25 } \\
\text { a\#1 }\end{array}$ & $\begin{array}{c}\text { USW } \\
\text { UZ-N32 }\end{array}$ & $\begin{array}{c}\text { USW } \\
\text { UZ-N31 }\end{array}$ & $\begin{array}{c}\text { USW } \\
\text { SD-12 }\end{array}$ & $\begin{array}{c}\text { USW } \\
\text { UZ-7a }\end{array}$ & $\begin{array}{l}\text { UE-25 } \\
\text { UZ \#16 }\end{array}$ & $\begin{array}{c}\text { USW } \\
\text { UZ-N55 }\end{array}$ \\
\hline \multicolumn{8}{|l|}{ Tiva Canyon Tuff (Tpc) } \\
\hline \multicolumn{8}{|l|}{ Tpcplnc } \\
\hline densely welded & $59.4 \pm 0.3$ & $27.1 \pm 0.2$ & $24.1 \pm 0.3$ & $71.6 \pm 0.3$ & $50.0 \pm 0.3$ & $43.4 \pm 0.4$ & $f$ \\
\hline moderately welded & 60.4 & 29.3 & 26.7 & $72.8 \pm 0.3$ & 52.1 & $47.0 \pm 0.1$ & $f$ \\
\hline Tpcpv2 & $62.5 \pm 0.2$ & 32.8 & 31.3 & 78.0 & $56.4 \pm 0.3$ & $47.5 \pm 0.1$ & $f$ \\
\hline Tpcpv1 & 66.3 & 34.5 & 32.5 & $80.4 \mathrm{v}$ & $60.4 \pm 0.05$ & 49.0 & $f$ \\
\hline \multicolumn{8}{|l|}{ Tpbt4 } \\
\hline unit $B$ & $f$ & 35.3 & 33.4 & $81.2 \pm 0.2$ & $61.0 \mathrm{v}$ & 49.6 & $f$ \\
\hline unit $A$ & $f$ & 36.0 & 34.0 & 81.8 & $62.1 \mathrm{v}$ & 50.6 & $f$ \\
\hline Tpy & $f$ & NP & NP & NP & & 52.8 & $f$ \\
\hline \multicolumn{8}{|l|}{ Tpbt3 } \\
\hline unit $G$ & $f$ & NP & $\mathrm{NP}$ & NP & $62.3 v$ & 53.6 & $f$ \\
\hline unit $F$ & $f$ & 36.2 & $>34.4$ & 82.6 & 62.5 & 54.0 & $f$ \\
\hline unit E & $f$ & NP & NR & NP & 62.55 & 54.1 & $f$ \\
\hline unit D & $f$ & 37.0 & NR & 82.9 & $63.2 \mathrm{v}$ & 54.9 & $f$ \\
\hline unit $C$ & $f$ & 37.6 & $35.3 \pm 0.05$ & 83.4 & $63.9 v$ & $55.5 \pm 0.1$ & $f$ \\
\hline unit $B$ & $f$ & 39.2 & 36.1 & 84.3 & $65.3 \pm 0.1$ & 56.8 & $f$ \\
\hline unit A & 66.6 & $39.6 \pm 0.05$ & 36.5 & $84.8 \mathrm{v}$ & 65.5 & 57.5 & $67.5 \mathrm{v}$ \\
\hline Tpp & $74.9 \pm 0.1$ & 48.3 & 44.0 & $88.8 \mathrm{v}$ & 66.6 & NP & \\
\hline \multicolumn{8}{|l|}{ Tpbt2 } \\
\hline unit $D$ & $75.7^{\circ}$ & 49.2 & 45.2 & $89.7 v$ & 67.8 & $59.2 \mathrm{v}$ & $68.7 \mathrm{v}$ \\
\hline unit $\mathrm{C}$ & $81.0 \pm 0.1+\dagger$ & $55.6 \pm 0.3$ & $51.1 \pm 0.2$ & $95.1 ? \mathrm{v}$ & $70.3 \pm 0.1$ & $66.3 v$ & $70.9 \mathrm{v}$ \\
\hline ash layer $\# 2$ & 78.5 & 53.8 & 48.9 & $?$ & 71.9 & 64.100 & 69.1 \\
\hline unit B & $82.3 \pm 0.1$ & $58.7 \pm 0.05$ & 53.1 & $97.2 \mathrm{v}$ & 74.1 & $67.7 v$ & $72.5 v$ \\
\hline ash layer \#1 & $81.3 \pm 0.1$ & 56.7 & 51.3 & 95.7 & $74.1 \mathrm{v}$ & $66.9 ? v$ & $71.1 \mathrm{v}$ \\
\hline \multicolumn{8}{|l|}{ Topopah Spring Tuff(Tpt) } \\
\hline Unit AI & 84.0 & 60.8 & 55.2 & $99.0 \mathrm{v}$ & $75.1 \pm 0.3$ & $69.9 v$ & $74.4 \mathrm{v}$ \\
\hline non/partially welded (Tptrv3) & $83.2 \pm 0.2$ & 60.4 & $54.8 \pm 0.05$ & 98.0 & $75.1 \pm 0.3$ & 69.5 & $73.5 ?$ \\
\hline moderately welded (Tptrv2) & 84.0 & 60.8 & 55.2 & $99.0 \mathrm{v}$ & $75.8 \pm 0.2 \dagger+\dagger$ & $69.9 v$ & $74.4 v$ \\
\hline
\end{tabular}

$\overrightarrow{\mathbb{N}}$ 
Depths to lithostratigraphic contacts in the Paintbrush Tuff nonwelded hydrologic unit at Yucca Mountain, Nevada--Continued

\begin{tabular}{|c|c|c|c|c|c|c|}
\hline & \multicolumn{6}{|c|}{ Borehole designation } \\
\hline & $\underset{\text { USW-N54 }}{\text { USW }}$ & $\begin{array}{c}\text { USW } \\
\text { UZ-N53 }\end{array}$ & $\begin{array}{l}\text { USW } \\
\text { SD-7 }\end{array}$ & $\begin{array}{l}\text { USW } \\
\text { GU-3 }\end{array}$ & $\begin{array}{c}\text { USW } \\
\text { UZ-N33 }\end{array}$ & $\begin{array}{c}\text { USW } \\
\text { UZ-N34 }\end{array}$ \\
\hline \multicolumn{7}{|l|}{ Tiva Canyon Tuff (Tpc) } \\
\hline \multicolumn{7}{|l|}{ Tpcplnc } \\
\hline densely welded & $42.4 \pm 0.2$ & $45.4 \pm 0.2$ & $92.0 \pm 0.3$ & $106.1 d$ & $\ddagger$ & ++ \\
\hline moderately welded & 44.3 & 45.9 & 92.8 & NP & + & + \\
\hline Tpcpv2 & 48.4 & $48.5 \pm 0.3$ & $95.0 \pm 0.1$ & $112.3 \pm 0.2$ & 6.9 & ++ \\
\hline Tpepvl & 51.1 & 52.8 & 99.3 & 114.1 & 13.5 & +4 \\
\hline \multicolumn{7}{|l|}{ Tpbt4 } \\
\hline unit B & NP & 53.3 & $100.8 \mathrm{v}$ & $115.2 \pm 0.2$ & 14.4 & ++ \\
\hline unit $A$ & 51.4 & 53.4 & NP & NP & NP & +4 \\
\hline Tpy & 53.5 & 55.0 & & NP & total depth & total depth \\
\hline \multicolumn{7}{|l|}{ Tpbt3 } \\
\hline unit $G$ & $>54.0$ & $>55.5$ & $101.5 \mathrm{v}$ & 116.1 & & \\
\hline unit $E$ & NR & NR & NP & NP & & \\
\hline unit $D$ & 55.3 & NR & 102.0 & 116.3 & & \\
\hline unit $\mathrm{C}$ & 55.8 & 57.1 & $102.5 \pm 0.45$ & 116.6 & & \\
\hline unit $B$ & 57.7 & $58.9 \pm 0.1$ & $>104.2$ & 118.3 & & \\
\hline unit $A$ & 58.3 & 59.6 & NR & 119.4 & & \\
\hline Tpp & NP & NP & NR & NP & & \\
\hline \multicolumn{7}{|l|}{ Tpbt2 } \\
\hline unit D & 59.6 & $61.0 \pm 0.05$ & NR & 119.4 & & \\
\hline unit $\mathrm{C}$ & $64.8 \pm 0.05$ & 66.0 & NR & $?$ & & \\
\hline ash layer \#2 & 64.1 & 65.2 & NR & $124.4 ? h$ & & \\
\hline unit $B$ & $66.6 \pm 0.2$ & $67.8 \pm 0.3$ & NR & $?$ & & \\
\hline ash layer \#l & 66.3 & 67.3 & NR & $127.3 ?$ & & \\
\hline \multicolumn{7}{|l|}{ Topopah Spring Tuff (Tpt) } \\
\hline unit $\mathrm{A} \rrbracket$ & $69.3 \pm 0.05$ & 69.4 & $115.3 \pm 1.8$ & 129.5 & & \\
\hline non/partially welded (Tptrv3) & $69.4 \pm 0.05$ & 69.4 & $115.3 \pm 1.8$ & 129.5 & & \\
\hline
\end{tabular}


Notes:

$\mathrm{NC}=$ Core not collected from this interval.

$\mathrm{NP}=$ Unit is not present.

$\mathrm{NR}=$ Unit is contained in a core interval that was removed, unrecovered, or is rubble

$? \quad=$ Contact is questionable or could not be determined.

$=$ Contact identified on videotape of core taken prior to sample removal.

1 = The base of unit $\mathrm{A}(\mathrm{Tpbt} 2)$ is the contact between pumiceous fallout and underlying pyroclastic-flow material. Where the base of unit $\mathrm{A}$ is not at the same depth as the base of the moderately welded subzone (Tptrv2), a thin interval of moderately welded pyroclastic-flow material separates the base of the fallout from the top of the densely welded Topopah Spring Tuff (either vitrophyre [Tptrv1] or devitrified tuff [Tptrn]).

** $=\mathrm{UZ}-14$ was spudded in Tpy

*** $=$ a\#7: Depths are not corrected for borehole inclination of $26^{\circ}$ from vertical.

$+\quad=$ NRG \#4: Fractures with slickensides noted at $144.6 \mathrm{~m}$

$\dagger=$ a\#1: Fractures with slickensides noted at 76.2 to $76.8 \mathrm{~m}$

t+ $=$ Tptrv2 overlies Tptrn; Tptrv1 is not present

$a=U Z-14$ : Unrecovered interval of $1.7 \mathrm{~m}$ moved from top of core run (83.1) to bottom of run (84.2)

$\mathrm{do}=\mathrm{UZ} \# 16$ : Unrecovered interval of $0.2 \mathrm{~m}$ placed at 63.9 to 64.1 . This contact could be $0.2 \mathrm{~m}$ higher (63.9).

coo $=$ SD-9: Unrecovered interval moved from 43.9 to $46.1 \mathrm{~m}$, bottom of the core run, to 43.8 to $45.9 \mathrm{~m}$, top of the run.

$f=$ Units appear to be structurally thinned or omitted.

$=$ GU-3: Alteration 122.2 to $124.8 \mathrm{~m}$.

= GU-3: Tpcpv3 is present from 104.7 to $106.1 \mathrm{~m}$. Where Tpcpv3 is present the moderately welded to densely welded contact equals the pv3 to pv2 contact.

$=$ UZ-N33: Not cored above $4.0 \mathrm{~m}$; first core recovered from Tpcpv2.

$\sharp=\mathrm{UZ}-\mathrm{N} 34$ : Alluvium/colluvium to $15.3 \mathrm{~m}$; first core recovered from Tpy. 
Appendix 4-Hydrologic-Property Data for Borehole Samples at Yucca Mountain, Nevada 
Hydrologic-Property Measurements of UZ-N11 Core Samples at Yucca Mountain, Nevada

[RH, relative humidity; ${ }^{\circ} \mathrm{C}$, degree Celsius; $\mathrm{m}$, meter; $\mathrm{g} / \mathrm{cm}^{3}$, gram per cubic centimeter; $\mathrm{cm}^{3} / \mathrm{cm}^{3}$, cubic centimeter per cubic centimeter]

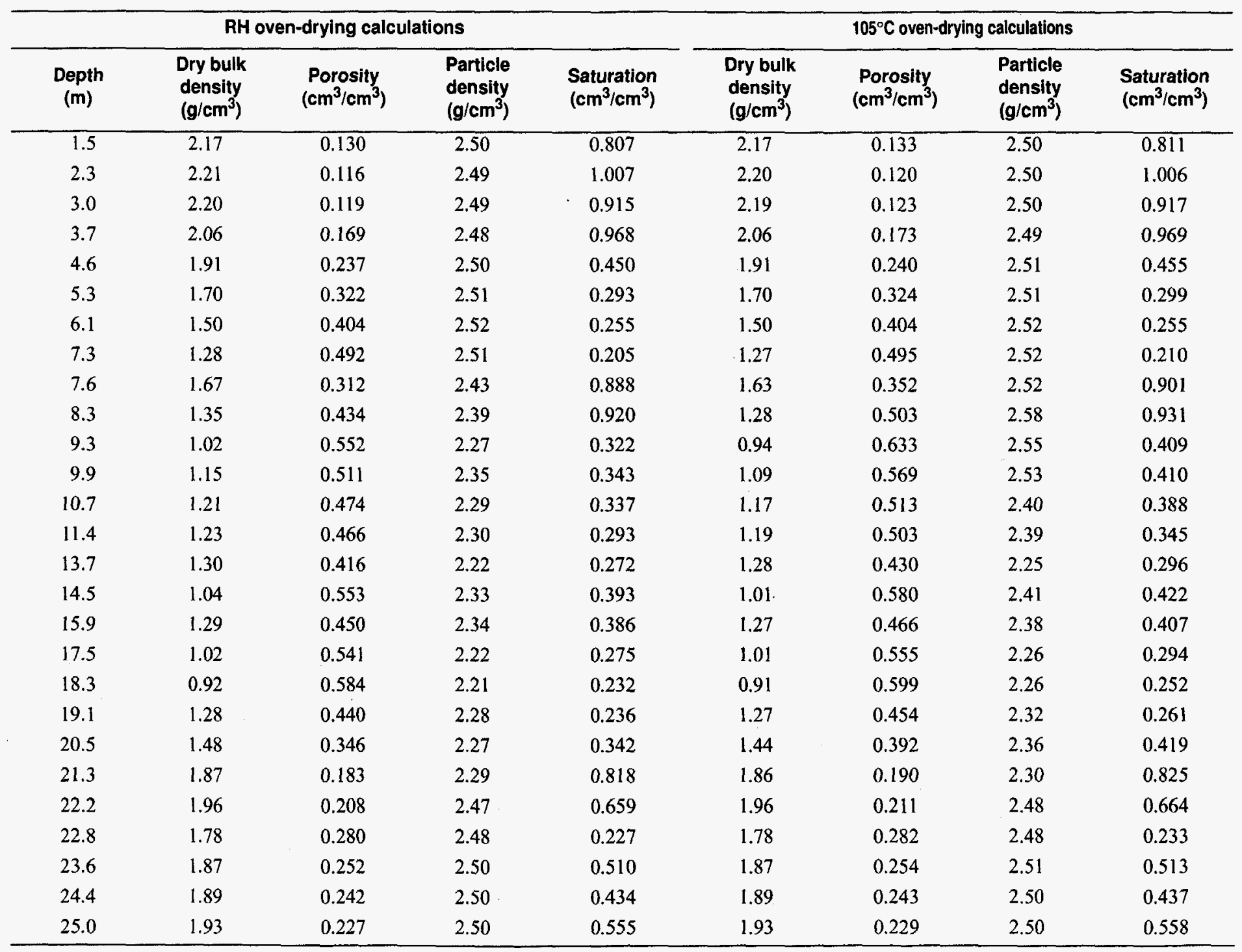


Hydrologic-Property Measurements of UZ-N31 Core Samples at Yucca Mountain, Nevada

[RH, relative humidity; ${ }^{\circ} \mathrm{C}$, degree Celsius; $\mathrm{m}$, meter; $\mathrm{g} / \mathrm{cm}^{3}$, gram per cubic centimeter; $\mathrm{cm}^{3} / \mathrm{cm}^{3}$, cubic centimeter per cubic centimeter]

\begin{tabular}{|c|c|c|c|c|c|c|c|c|}
\hline \multicolumn{5}{|c|}{ RH oven-drying calculations } & \multicolumn{4}{|c|}{$105^{\circ} \mathrm{C}$ oven-drying calculations } \\
\hline $\begin{array}{c}\text { Depth } \\
\text { (m) }\end{array}$ & $\begin{array}{l}\text { Dry bulk } \\
\text { density } \\
\left(\mathrm{g} / \mathrm{cm}^{3}\right)\end{array}$ & $\begin{array}{l}\text { Porosity } \\
\left(\mathrm{cm}^{3} / \mathrm{cm}^{3}\right)\end{array}$ & $\begin{array}{l}\text { Particle } \\
\text { density } \\
\left(\mathrm{g} / \mathrm{cm}^{3}\right)\end{array}$ & $\begin{array}{l}\text { Saturation } \\
\left(\mathrm{cm}^{3} / \mathrm{cm}^{3}\right)\end{array}$ & $\begin{array}{l}\text { Dry bulk } \\
\text { density } \\
\left(\mathrm{g} / \mathrm{cm}^{3}\right)\end{array}$ & $\begin{array}{l}\text { Porosity } \\
\left(\mathrm{cm}^{3} / \mathrm{cm}^{3}\right)\end{array}$ & $\begin{array}{l}\text { Particle } \\
\text { density } \\
\left(\mathbf{g} / \mathrm{cm}^{3}\right)\end{array}$ & $\begin{array}{l}\text { Saturation } \\
\left(\mathrm{cm}^{3} / \mathrm{cm}^{3}\right)\end{array}$ \\
\hline 20.9 & 2.25 & 0.082 & 2.46 & 0.820 & 2.23 & 0.105 & 2.49 & 0.859 \\
\hline 21.5 & 2.22 & 0.097 & 2.46 & 0.838 & 2.19 & 0.123 & 2.50 & 0.872 \\
\hline 22.2 & 2.23 & 0.092 & 2.45 & 0.912 & 2.20 & 0.120 & 2.50 & 0.933 \\
\hline 23.0 & 2.18 & 0.107 & 2.44 & 0.796 & 2.15 & 0.136 & 2.49 & 0.839 \\
\hline 24.0 & 2.12 & 0.138 & 2.45 & 0.977 & 2.09 & 0.165 & 2.50 & 0.980 \\
\hline 24.6 & 2.08 & 0.152 & 2.46 & 0.933 & 2.06 & 0.177 & 2.50 & 0.942 \\
\hline 25.5 & 1.99 & 0.221 & 2.56 & 0.886 & 1.97 & 0.243 & 2.60 & 0.896 \\
\hline 26.2 & 2.13 & 0.135 & 2.46 & 0.907 & 2.08 & 0.182 & 2.54 & 0.931 \\
\hline 26.9 & 2.12 & 0.082 & 2.31 & 0.988 & 2.01 & 0.189 & 2.48 & 0.995 \\
\hline 27.6 & 2.09 & 0.097 & 2.31 & 0.968 & 2.00 & 0.183 & 2.45 & 0.983 \\
\hline 28.4 & 2.04 & 0.115 & 2.31 & 0.991 & 1.96 & 0.191 & 2.43 & 0.995 \\
\hline 29.3 & 1.87 & 0.166 & 2.24 & 0.978 & 1.77 & 0.262 & 2.40 & 0.986 \\
\hline 30.0 & 1.77 & 0.202 & 2.21 & 0.989 & 1.67 & 0.303 & 2.39 & 0.993 \\
\hline 30.8 & 1.54 & 0.295 .3 & 2.18 & 0.974 & 1.42 & 0.411 & 2.41 & 0.982 \\
\hline 31.6 & 1.45 & 0.344 & 2.21 & 0.995 & 1.35 & 0.436 & 2.40 & 0.996 \\
\hline 31.9 & 1.51 & 0.298 & 2.16 & 1.000 & 1.40 & 0.417 & 2.40 & 1.000 \\
\hline 32.3 & 1.63 & 0.254 & 2.18 & 1.017 & 1.49 & 0.392 & 2.45 & 1.011 \\
\hline 32.5 & 1.94 & 0.167 & 2.33 & 0.966 & 1.81 & 0.297 & 2.58 & 0.981 \\
\hline 32.9 & 2.01 & 0.129 & 2.31 & 0.873 & 1.94 & 0.204 & 2.44 & 0.920 \\
\hline 33.2 & 1.87 & 0.197 & 2.33 & 0.722 & 1.80 & 0.269 & 2.46 & 0.796 \\
\hline 33.4 & 2.19 & 0.090 & 2.41 & 0.679 & 2.15 & 0.134 & 2.48 & 0.784 \\
\hline 33.9 & 1.47 & 0.358 & 2.28 & 0.526 & 1.40 & 0.419 & 2.42 & 0.595 \\
\hline 34.1 & 1.32 & 0.431 & 2.32 & 0.517 & 1.26 & 0.492 & 2.48 & 0.578 \\
\hline 34.4 & 1.99 & 0.169 & 2.40 & 0.583 & 1.95 & 0.213 & 2.48 & 0.670 \\
\hline 35.3 & 1.44 & 0.377 & 2.30 & 0.426 & 1.37 & 0.438 & 2.45 & 0.507 \\
\hline 36.2 & 1.20 & 0.481 & 2.31 & 0.383 & 1.14 & 0.536 & 2.46 & 0.446 \\
\hline
\end{tabular}


Hydrologic-Property Measurements of UZ-N31 Core Samples at Yucca Mountain, Nevada--Continued

\begin{tabular}{|c|c|c|c|c|c|c|c|c|}
\hline \multicolumn{5}{|c|}{ RH oven-drying calculations } & \multicolumn{4}{|c|}{$105^{\circ} \mathrm{C}$ oven-drying calculations } \\
\hline $\begin{array}{l}\text { Depth } \\
(\mathrm{m})\end{array}$ & $\begin{array}{l}\text { Dry bulk } \\
\text { density } \\
\left(\mathbf{g} / \mathrm{cm}^{3}\right)\end{array}$ & $\begin{array}{l}\text { Porosity } \\
\left(\mathrm{cm}^{3} / \mathrm{cm}^{3}\right)\end{array}$ & $\begin{array}{l}\text { Particle } \\
\text { density } \\
\left(\mathrm{g} / \mathrm{cm}^{3}\right)\end{array}$ & $\begin{array}{l}\text { Saturation } \\
\left(\mathrm{cm}^{3} / \mathrm{cm}^{3}\right)\end{array}$ & $\begin{array}{l}\text { Dry bulk } \\
\text { density } \\
\left(\mathrm{g} / \mathrm{cm}^{3}\right)\end{array}$ & $\begin{array}{c}\text { Porosity } \\
\left(\mathrm{cm}^{3} / \mathrm{cm}^{3}\right)\end{array}$ & $\begin{array}{l}\text { Particle } \\
\text { density } \\
\left(\mathrm{g} / \mathrm{cm}^{3}\right)\end{array}$ & $\begin{array}{l}\text { Saturation } \\
\left(\mathrm{cm}^{3} / \mathrm{cm}^{3}\right)\end{array}$ \\
\hline 36.8 & 1.19 & 0.473 & 2.25 & 0.423 & 1.15 & 0.510 & 2.35 & 0.465 \\
\hline 38.3 & 1.22 & 0.438 & 2.17 & 0.454 & 1.19 & 0.466 & 2.23 & 0.486 \\
\hline 39.4 & 1.00 & 0.562 & 2.29 & 0.306 & 0.98 & 0.584 & 2.36 & 0.332 \\
\hline 39.9 & 1.12 & 0.490 & 2.19 & 0.427 & 1.10 & 0.510 & 2.24 & 0.448 \\
\hline 40.6 & 1.09 & 0.494 & 2.15 & 0.434 & 1.07 & 0.510 & 2.19 & 0.452 \\
\hline 41.5 & 1.06 & 0.527 & 2.24 & 0.441 & 1.04 & 0.542 & 2.28 & 0.456 \\
\hline 42.2 & 1.19 & 0.452 & 2.17 & 0.459 & 1.17 & 0.469 & 2.21 & 0.479 \\
\hline 43.0 & 1.28 & 0.418 & 2.20 & 0.579 & 1.25 & 0.441 & 2.24 & 0.601 \\
\hline 43.7 & 1.28 & 0.421 & 2.21 & 0.640 & 1.24 & 0.454 & 2.28 & 0.666 \\
\hline 44.5 & 1.43 & 0.370 & 2.27 & 0.452 & 1.38 & 0.420 & 2.38 & 0.517 \\
\hline 45.2 & 1.36 & 0.406 & 2.29 & 0.495 & 1.30 & 0.467 & 2.43 & 0.562 \\
\hline 46.0 & 1.14 & 0.495 & 2.27 & 0.412 & 1.12 & 0.520 & 2.33 & 0.441 \\
\hline 46.7 & 1.14 & 0.495 & 2.26 & 0.464 & 1.11 & 0.520 & 2.32 & 0.490 \\
\hline 47.5 & 1.07 & 0.520 & 2.22 & 0.326 & 1.04 & 0.548 & 2.30 & 0.360 \\
\hline 48.3 & 1.17 & 0.486 & 2.27 & 0.400 & 1.14 & 0.517 & 2.36 & 0.437 \\
\hline 49.1 & 1.13 & 0.504 & 2.28 & 0.403 & 1.09 & 0.542 & 2.39 & 0.444 \\
\hline 49.8 & 0.99 & 0.563 & 2.27 & 0.331 & 0.97 & 0.588 & 2.35 & 0.359 \\
\hline 50.7 & 1.05 & 0.541 & 2.28 & 0.407 & 1.02 & 0.573 & 2.38 & 0.440 \\
\hline 51.3 & 1.13 & 0.515 & 2.33 & 0.290 & 1.11 & 0.541 & 2.41 & 0.324 \\
\hline 52.1 & 1.09 & 0.514 & 2.24 & 0.530 & 1.04 & 0.563 & 2.38 & 0.571 \\
\hline 52.8 & 1.11 & 0.509 & 2.26 & 0.595 & 1.07 & 0.553 & 2.38 & 0.628 \\
\hline 53.6 & 1.12 & 0.494 & 2.20 & 0.559 & 1.07 & 0.536 & 2.31 & 0.594 \\
\hline 54.3 & 1.23 & 0.441 & 2.21 & 0.625 & 1.21 & 0.462 & 2.25 & 0.641 \\
\hline 54.8 & 1.48 & 0.342 & 2.25 & 0.695 & 1.46 & 0.355 & 2.27 & 0.707 \\
\hline 55.7 & 2.34 & 0.046 & 2.45 & 1.029 & 2.33 & 0.054 & 2.46 & 1.025 \\
\hline 56.3 & 1.82 & 0.257 & 2.45 & 0.576 & 1.80 & 0.273 & 2.48 & 0.601 \\
\hline 56.9 & 2.47 & 0.019 & 2.52 & 0.332 & 2.46 & 0.029 & 2.53 & 0.565 \\
\hline
\end{tabular}


Hydrologic-Property Measurements of UZ-N32 Core Samples at Yucca Mountain, Nevada

$\left[R H\right.$, relative humidity; ${ }^{\circ} \mathrm{C}$, degree Celsius; $\mathrm{m}$, meter, $\mathrm{g} / \mathrm{cm}^{3}$, gram per cubic centimeter; $\mathrm{cm}^{3} / \mathrm{cm}^{3}$, cubic centimeter per cubic centimeter; ${ }^{* *}$, samples disaggregated during saturation, values are questionable]

\begin{tabular}{|c|c|c|c|c|c|c|c|c|c|}
\hline \multirow[b]{2}{*}{$\begin{array}{l}\text { Depth } \\
\text { (m) }\end{array}$} & \multicolumn{4}{|c|}{ RH oven-drying calculations } & \multicolumn{4}{|c|}{$105^{\circ} \mathrm{C}$ oven-drying calculations } & \\
\hline & $\begin{array}{l}\text { Dry bulk } \\
\text { density } \\
\left(\mathbf{g} / \mathrm{cm}^{3}\right)\end{array}$ & $\begin{array}{l}\text { Porosity } \\
\left(\mathrm{cm}^{3} / \mathrm{cm}^{3}\right)\end{array}$ & $\begin{array}{l}\text { Particle } \\
\text { density } \\
\left(\mathrm{g} / \mathrm{cm}^{3}\right)\end{array}$ & $\begin{array}{l}\text { Saturation } \\
\left(\mathrm{cm}^{3} / \mathrm{cm}^{3}\right)\end{array}$ & $\begin{array}{l}\text { Dry bulk } \\
\text { density } \\
\left(\mathrm{g} / \mathrm{cm}^{3}\right)\end{array}$ & $\begin{array}{l}\text { Porosity } \\
\left(\mathrm{cm}^{3} / \mathrm{cm}^{3}\right)\end{array}$ & $\begin{array}{l}\text { Particle } \\
\text { density } \\
\left(\mathrm{g} / \mathrm{cm}^{3}\right)\end{array}$ & $\begin{array}{l}\text { Saturation } \\
\left(\mathrm{cm}^{3} / \mathrm{cm}^{3}\right)\end{array}$ & \\
\hline 23.5 & 2.26 & 0.081 & 2.45 & 0.782 & 2.24 & 0.096 & 2.48 & 0.817 & \\
\hline 24.3 & 2.25 & 0.084 & 2.46 & 0.868 & 2.23 & 0.107 & 2.50 & 0.897 & \\
\hline 25.5 & 2.17 & 0.118 & 2.46 & 0.854 & 2.14 & 0.142 & 2.50 & 0.879 & \\
\hline 26.3 & 2.16 & 0.121 & 2.46 & 0.795 & 2.14 & 0.145 & 2.50 & 0.829 & \\
\hline 27.4 & 2.09 & 0.149 & 2.46 & 0.902 & 2.07 & 0.173 & 2.50 & 0.915 & \\
\hline 28.1 & 2.05 & 0.148 & 2.40 & 0.658 & 2.03 & 0.170 & 2.44 & 0.703 & \\
\hline 28.7 & 2.13 & 0.116 & 2.41 & 0.849 & 2.09 & 0.155 & 2.48 & 0.887 & \\
\hline 29.8 & 2.05 & 0.103 & 2.29 & 0.972 & 1.97 & 0.189 & 2.42 & 0.985 & \\
\hline 30.6 & 2.01 & 0.117 & 2.28 & 0.892 & 1.92 & 0.210 & 2.43 & 0.939 & \\
\hline 31.1 & 1.97 & 0.140 & 2.30 & 0.978 & 1.91 & 0.206 & 2.40 & 0.985 & \\
\hline 31.8 & 1.77 & 0.209 & 2.24 & 0.971 & 1.67 & 0.311 & 2.43 & 0.981 & \\
\hline 32.5 & 1.66 & 0.272 & 2.28 & 0.888 & 1.62 & 0.311 & 2.35 & 0.902 & \\
\hline 33.0 & 1.52 & 0.337 & 2.28 & 0.879 & 1.48 & 0.368 & 2.35 & 0.889 & \\
\hline 33.7 & 1.49 & 0.350 & 2.29 & 0.742 & 1.47 & 0.369 & 2.33 & 0.755 & \\
\hline 34.3 & 1.40 & 0.391 & 2.30 & 0.870 & 1.35 & 0.441 & 2.41 & 0.885 & $* *$ \\
\hline 35.0 & 1.08 & 0.483 & 2.08 & 0.668 & 0.89 & 0.669 & 2.69 & 0.760 & $* *$ \\
\hline 35.8 & 1.52 & 0.314 & 2.22 & 0.541 & 1.41 & 0.426 & 2.46 & 0.662 & $* *$ \\
\hline 36.7 & 1.13 & 0.500 & 2.26 & 0.543 & 1.05 & 0.578 & 2.49 & 0.604 & ** \\
\hline 37.3 & 1.28 & 0.438 & 2.28 & 0.568 & 1.20 & 0.520 & 2.50 & 0.636 & $* *$ \\
\hline 37.9 & 1.54 & 0.307 & 2.23 & 0.581 & 1.43 & 0.423 & 2.48 & 0.695 & ** \\
\hline 38.7 & 1.38 & 0.391 & 2.26 & 0.490 & 1.30 & 0.470 & 2.45 & 0.576 & $* *$ \\
\hline 39.6 & 1.14 & 0.506 & 2.31 & 0.374 & 1.09 & 0.558 & 2.47 & 0.432 & ** \\
\hline 40.4 & 1.19 & 0.469 & 2.23 & 0.418 & 1.15 & 0.508 & 2.33 & 0.462 & $* *$ \\
\hline 41.1 & 1.21 & 0.461 & 2.24 & 0.395 & 1.18 & 0.491 & 2.31 & 0.432 & $* *$ \\
\hline 41.9 & 1.21 & 0.450 & 2.20 & 0.438 & 1.19 & 0.475 & 2.26 & 0.467 & $* *$ \\
\hline 42.6 & 1.02 & 0.539 & 2.21 & 0.338 & 1.00 & 0.559 & 2.27 & 0.362 & ** \\
\hline
\end{tabular}


Hydrologic-Property Measurements of UZ-N32 Core Samples at Yucca Mountain, Nevada--Continued

\begin{tabular}{|c|c|c|c|c|c|c|c|c|c|}
\hline \multirow[b]{2}{*}{$\begin{array}{c}\text { Depth } \\
\text { (m) }\end{array}$} & \multicolumn{4}{|c|}{$\mathrm{RH}$ oven-drying calculations } & \multicolumn{4}{|c|}{$105^{\circ} \mathrm{C}$ oven-drying calculations } & \\
\hline & $\begin{array}{l}\text { Dry bulk } \\
\text { density } \\
\left(\mathbf{g} / \mathrm{cm}^{3}\right)\end{array}$ & $\begin{array}{l}\text { Porosity } \\
\left(\mathrm{cm}^{3} / \mathrm{cm}^{3}\right)\end{array}$ & $\begin{array}{l}\text { Particle } \\
\text { density } \\
\left(\mathrm{g} / \mathrm{cm}^{3}\right)\end{array}$ & $\begin{array}{l}\text { Saturation } \\
\left(\mathrm{cm}^{3} / \mathrm{cm}^{3}\right)\end{array}$ & $\begin{array}{l}\text { Dry bulk } \\
\text { density } \\
\left(\mathrm{g} / \mathrm{cm}^{3}\right)\end{array}$ & $\begin{array}{l}\text { Porosity } \\
\left(\mathrm{cm}^{3} / \mathrm{cm}^{3}\right)\end{array}$ & $\begin{array}{l}\text { Particle } \\
\text { density } \\
\left(\mathrm{g} / \mathrm{cm}^{3}\right)\end{array}$ & $\begin{array}{l}\text { Saturation } \\
\left(\mathrm{cm}^{3} / \mathrm{cm}^{3}\right)\end{array}$ & \\
\hline 43.4 & 1.10 & 0.510 & 2.25 & 0.355 & 1.08 & 0.533 & 2.31 & 0.381 & $* *$ \\
\hline 45.0 & 1.13 & 0.483 & 2.19 & 0.374 & 1.12 & 0.500 & 2.23 & 0.395 & $* *$ \\
\hline 45.8 & 1.12 & 0.498 & 2.23 & 0.365 & 1.11 & 0.513 & 2.27 & 0.384 & $* *$ \\
\hline 46.3 & 1.19 & 0.452 & 2.18 & 0.429 & 1.18 & 0.466 & 2.21 & 0.446 & $* *$ \\
\hline 47.3 & 1.28 & 0.440 & 2.28 & 0.448 & 1.26 & 0.456 & 2.32 & 0.467 & $* *$ \\
\hline 48.0 & 1.25 & 0.437 & 2.22 & 0.628 & 1.23 & 0.457 & 2.26 & 0.643 & $* *$ \\
\hline 48.8 & 1.42 & 0.372 & 2.27 & 0.478 & 1.38 & 0.411 & 2.35 & 0.527 & $* *$ \\
\hline 49.5 & 1.41 & 0.346 & 2.15 & 0.713 & 1.30 & 0.451 & 2.37 & 0.780 & $* *$ \\
\hline 50.3 & 1.38 & 0.374 & 2.20 & 0.512 & 1.26 & 0.491 & 2.47 & 0.628 & $* *$ \\
\hline 51.0 & 1.16 & 0.474 & 2.20 & 0.393 & 1.10 & 0.537 & 2.37 & 0.465 & $* *$ \\
\hline 51.8 & 1.10 & 0.506 & 2.22 & 0.285 & 1.06 & 0.537 & 2.30 & 0.327 & $* *$ \\
\hline 52.5 & 1.10 & 0.503 & 2.22 & 0.335 & 1.06 & 0.545 & 2.33 & 0.387 & $* *$ \\
\hline 53.3 & 1.08 & 0.514 & 2.22 & 0.420 & 1.02 & 0.570 & 2.38 & 0.478 & $* *$ \\
\hline 53.9 & 1.10 & 0.510 & 2.25 & 0.342 & 1.05 & 0.558 & 2.38 & 0.399 & $* *$ \\
\hline 54.8 & 1.06 & 0.520 & 2.22 & 0.353 & 1.01 & 0.573 & 2.37 & 0.413 & $* *$ \\
\hline 55.6 & 1.01 & 0.546 & 2.23 & 0.378 & 0.96 & 0.602 & 2.40 & 0.436 & $* *$ \\
\hline 56.2 & 1.10 & 0.505 & 2.23 & 0.435 & 1.04 & 0.573 & 2.43 & 0.501 & $* *$ \\
\hline 57.2 & 1.03 & 0.548 & 2.29 & 0.369 & 0.98 & 0.608 & 2.49 & 0.431 & $* *$ \\
\hline 57.9 & 1.06 & 0.520 & 2.22 & 0.435 & 0.98 & 0.599 & 2.45 & 0.509 & $* *$ \\
\hline 58.7 & 1.08 & 0.513 & 2.22 & 0.487 & 1.00 & 0.599 & 2.48 & 0.561 & $* *$ \\
\hline 59.4 & 1.12 & 0.500 & 2.24 & 0.453 & 1.07 & 0.547 & 2.37 & 0.500 & $* *$ \\
\hline 60.2 & 1.54 & 0.302 & 2.21 & 0.715 & 1.51 & 0.332 & 2.26 & 0.741 & \\
\hline 61.0 & 2.34 & 0.031 & 2.42 & 0.937 & 2.32 & 0.050 & 2.45 & 0.961 & \\
\hline 61.7 & 2.38 & 0.044 & 2.49 & 0.712 & 2.38 & 0.050 & 2.50 & 0.745 & \\
\hline 62.0 & 2.48 & 0.021 & 2.53 & 0.200 & 2.47 & 0.028 & 2.55 & 0.410 & \\
\hline 62.2 & 2.32 & 0.067 & 2.49 & 0.357 & 2.31 & 0.076 & 2.50 & 0.436 & \\
\hline
\end{tabular}


Hydrologic-Property Measurements of UZ-N33 Core Samples at Yucca Mountain, Nevada

[RH, relative humidity; ${ }^{\circ} \mathrm{C}$, degree Celsius; $\mathrm{m}$, meter; $\mathrm{g} / \mathrm{cm}^{3}$, gram per cubic centimeter; $\mathrm{cm}^{3} / \mathrm{cm}^{3}$, cubic centimeter per cubic centimeter]

\begin{tabular}{|c|c|c|c|c|c|c|c|c|}
\hline \multicolumn{5}{|c|}{ RH oven-drying calculations } & \multicolumn{4}{|c|}{$105^{\circ} \mathrm{C}$ oven-drying calculations } \\
\hline $\begin{array}{l}\text { Depth } \\
\text { (m) }\end{array}$ & $\begin{array}{l}\text { Dry bulk } \\
\text { density } \\
\left(\mathrm{g} / \mathrm{cm}^{3}\right)\end{array}$ & $\begin{array}{l}\text { Porosity } \\
\left(\mathrm{cm}^{3} / \mathrm{cm}^{3}\right)\end{array}$ & $\begin{array}{l}\text { Particle } \\
\text { density } \\
\left(\mathrm{g} / \mathrm{cm}^{3}\right)\end{array}$ & $\begin{array}{l}\text { Saturation } \\
\left(\mathrm{cm}^{3} / \mathrm{cm}^{3}\right)\end{array}$ & $\begin{array}{l}\text { Dry bulk } \\
\text { density } \\
\left(\mathrm{g} / \mathrm{cm}^{3}\right)\end{array}$ & $\begin{array}{l}\text { Porosity } \\
\left(\mathrm{cm}^{3} / \mathrm{cm}^{3}\right)\end{array}$ & $\begin{array}{l}\text { Particle } \\
\text { density } \\
\left(\mathrm{g} / \mathrm{cm}^{3}\right)\end{array}$ & $\begin{array}{l}\text { Saturation } \\
\left(\mathrm{cm}^{3} / \mathrm{cm}^{3}\right)\end{array}$ \\
\hline 4.0 & 2.15 & 0.041 & 2.24 & 0.828 & 2.04 & 0.143 & 2.39 & 0.951 \\
\hline 4.6 & 2.14 & 0.050 & 2.26 & 0.940 & 2.07 & 0.120 & 2.36 & 0.975 \\
\hline 5.3 & 2.10 & 0.079 & 2.28 & 0.967 & 2.03 & 0.150 & 2.39 & 0.983 \\
\hline 6.1 & 2.03 & 0.103 & 2.26 & 0.945 & 1.95 & 0.176 & 2.37 & 0.968 \\
\hline 6.9 & 1.89 & 0.146 & 2.21 & 0.927 & 1.78 & 0.256 & 2.40 & 0.959 \\
\hline 7.4 & 1.79 & 0.138 & 2.08 & 0.950 & 1.66 & 0.267 & 2.27 & 0.974 \\
\hline 8.4 & 1.64 & 0.185 & 2.01 & 0.944 & 1.53 & 0.296 & 2.17 & 0.965 \\
\hline 9.1 & 1.54 & 0.179 & 1.88 & 0.875 & 1.42 & 0.299 & 2.03 & 0.926 \\
\hline 9.7 & 1.45 & 0.277 & 2.01 & 0.711 & 1.33 & 0.399 & 2.21 & 0.799 \\
\hline 10.6 & 1.34 & 0.349 & 2.06 & 0.612 & 1.22 & 0.475 & 2.32 & 0.715 \\
\hline 10.7 & 1.40 & 0.316 & 2.05 & 0.639 & 1.27 & 0.443 & 2.29 & 0.742 \\
\hline 11.4 & 1.35 & 0.366 & 2.13 & 0.536 & 1.26 & 0.457 & 2.32 & 0.629 \\
\hline 12.2 & 1.40 & 0.356 & 2.18 & 0.613 & 1.32 & 0.439 & 2.35 & 0.686 \\
\hline 12.8 & 1.32 & 0.390 & 2.17 & 0.436 & 1.25 & 0.456 & 2.31 & 0.518 \\
\hline 13.7 & 1.14 & 0.480 & 2.20 & 0.579 & 1.02 & 0.600 & 2.56 & 0.663 \\
\hline 14.4 & 1.25 & 0.392 & 2.05 & 0.404 & 1.20 & 0.441 & 2.15 & 0.471 \\
\hline 15.2 & 1.27 & 0.374 & 2.04 & 0.389 & 1.23 & 0.414 & 2.11 & 0.448 \\
\hline 16.0 & 1.32 & 0.388 & 2.15 & 0.407 & 1.28 & 0.423 & 2.22 & 0.456 \\
\hline 16.7 & 1.37 & 0.363 & 2.15 & 0.531 & 1.33 & 0.404 & 2.23 & 0.579 \\
\hline 17.5 & 1.48 & 0.333 & 2.22 & 0.778 & 1.45 & 0.363 & 2.28 & 0.796 \\
\hline 18.2 & 1.61 & 0.308 & 2.33 & 0.858 & 1.60 & 0.319 & 2.35 & 0.863 \\
\hline 19.0 & 2.17 & 0.025 & 2.23 & 0.771 & 2.13 & 0.073 & 2.29 & 0.921 \\
\hline 19.8 & 1.90 & 0.187 & 2.33 & 0.630 & 1.87 & 0.211 & 2.37 & 0.673 \\
\hline 20.6 & 1.77 & 0.281 & 2.46 & 0.422 & 1.76 & 0.293 & 2.48 & 0.446 \\
\hline 21.3 & 1.80 & 0.262 & 2.44 & 0.501 & 1.78 & 0.276 & 2.46 & 0.527 \\
\hline 22.1 & 1.86 & 0.240 & 2.45 & 0.548 & 1.84 & 0.257 & 2.48 & 0.578 \\
\hline 22.5 & 1.92 & 0.192 & 2.37 & 0.729 & 1.90 & 0.213 & 2.41 & 0.756 \\
\hline
\end{tabular}


Hydrologic-Property Measurements of UZ-N34 Core Samples at Yucca Mountain, Nevada

[RH, relative humidity; ${ }^{\circ} \mathrm{C}$, degree Celsius; $\mathrm{m}$, meter; $\mathrm{g} / \mathrm{cm}^{3}$, gram per cubic centimeter; $\mathrm{cm}^{3} / \mathrm{cm}^{3}$, cubic centimeter per cubic centimeter]

\begin{tabular}{|c|c|c|c|c|c|c|c|c|}
\hline \multicolumn{5}{|c|}{ RH oven-drying calculations } & \multicolumn{4}{|c|}{$105^{\circ} \mathrm{C}$ oven-drying calculations } \\
\hline $\begin{array}{c}\text { Depth } \\
(m)\end{array}$ & $\begin{array}{l}\text { Dry bulk } \\
\text { density } \\
\left(\mathrm{g} / \mathrm{cm}^{3}\right)\end{array}$ & $\begin{array}{l}\text { Porosity } \\
\left(\mathrm{cm}^{3} / \mathrm{cm}^{3}\right)\end{array}$ & $\begin{array}{l}\text { Particle } \\
\text { density } \\
\left(\mathrm{g} / \mathrm{cm}^{3}\right)\end{array}$ & $\begin{array}{l}\text { Saturation } \\
\left(\mathrm{cm}^{3} / \mathrm{cm}^{3}\right)\end{array}$ & $\begin{array}{l}\text { Dry bulk } \\
\text { density } \\
\left(\mathrm{g} / \mathrm{cm}^{3}\right)\end{array}$ & $\begin{array}{c}\text { Porosity } \\
\left(\mathrm{cm}^{3} / \mathrm{cm}^{3}\right)\end{array}$ & $\begin{array}{l}\text { Particle } \\
\text { density } \\
\left(\mathrm{g} / \mathrm{cm}^{3}\right)\end{array}$ & $\begin{array}{l}\text { Saturation } \\
\left(\mathrm{cm}^{3} / \mathrm{cm}^{3}\right)\end{array}$ \\
\hline 15.4 & 1.38 & 0.358 & 2.15 & 0.507 & 1.28 & 0.462 & 2.38 & 0.618 \\
\hline 16.0 & 1.51 & 0.304 & 2.16 & 0.610 & 1.39 & 0.414 & 2.38 & 0.714 \\
\hline 16.9 & 1.68 & 0.257 & 2.26 & 0.720 & 1.63 & 0.301 & 2.34 & 0.761 \\
\hline 19.3 & 1.84 & 0.241 & 2.43 & 0.628 & 1.82 & 0.264 & 2.47 & 0.660 \\
\hline 19.9 & 1.81 & 0.259 & 2.45 & 0.450 & 1.80 & 0.275 & 2.48 & 0.482 \\
\hline 20.7 & 1.85 & 0.248 & 2.46 & 0.517 & 1.83 & 0.262 & 2.48 & 0.542 \\
\hline 21.5 & 1.84 & 0.255 & 2.47 & 0.633 & 1.83 & 0.265 & 2.50 & 0.647 \\
\hline 21.8 & 1.88 & 0.234 & 2.46 & 0.724 & 1.87 & 0.249 & 2.49 & 0.741 \\
\hline 25.2 & 1.90 & 0.201 & 2.38 & 0.958 & 1,89 & 0.211 & 2.39 & 0.960 \\
\hline
\end{tabular}

Hydrologic-Property Measurements of UZ-N37 Core Samples at Yucca Mountain, Nevada

$\left[\mathrm{RH}\right.$, relative humidity; ${ }^{\circ} \mathrm{C}$, degree Celsius; $\mathrm{m}$, meter; $\mathrm{g} / \mathrm{cm}^{3}$, gram per cubic centimeter; $\mathrm{cm}^{3} / \mathrm{cm}^{3}$, cubic centimeter per cubic centimeter; ${ }^{* *}$, samples disaggregated during saturation, values are questionable]

\begin{tabular}{|c|c|c|c|c|c|c|c|c|c|}
\hline \multirow{6}{*}{ 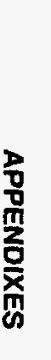 } & \multicolumn{5}{|c|}{ RH oven-drying calculations } & \multicolumn{4}{|c|}{$105^{\circ} \mathrm{C}$ oven-drying calculations } \\
\hline & $\begin{array}{l}\text { Depth } \\
\text { (m) }\end{array}$ & $\begin{array}{l}\text { Dry bulk } \\
\text { density } \\
\left(\mathrm{g} / \mathrm{cm}^{3}\right)\end{array}$ & $\begin{array}{l}\text { Porosity } \\
\left(\mathrm{cm}^{3} / \mathrm{cm}^{3}\right)\end{array}$ & $\begin{array}{l}\text { Particle } \\
\text { density } \\
\left(\mathrm{g} / \mathrm{cm}^{3}\right)\end{array}$ & $\begin{array}{l}\text { Saturation } \\
\left(\mathrm{cm}^{3} / \mathrm{cm}^{3}\right)\end{array}$ & $\begin{array}{l}\text { Dry bulk } \\
\text { density } \\
\left(\mathrm{g} / \mathrm{cm}^{3}\right)\end{array}$ & $\begin{array}{l}\text { Porosity } \\
\left(\mathrm{cm}^{3} / \mathrm{cm}^{3}\right)\end{array}$ & $\begin{array}{l}\text { Particle } \\
\text { density } \\
\left(\mathrm{g} / \mathrm{cm}^{3}\right)\end{array}$ & $\begin{array}{l}\text { Saturation } \\
\left(\mathrm{cm}^{3} / \mathrm{cm}^{3}\right)\end{array}$ \\
\hline & 29.0 & 2.10 & 0.159 & 2.50 & 0.809 & 2.09 & 0.164 & 2.50 & 0.814 \\
\hline & 29.7 & 2.04 & 0.183 & 2.49 & 0.919 & 2.03 & 0.189 & 2.50 & 0.922 \\
\hline & 30.5 & 2.01 & 0.194 & 2.50 & 0.818 & 2.01 & 0.198 & 2.51 & 0.822 \\
\hline & 31.3 & 1.97 & 0.211 & 2.50 & 0.898 & 1.97 & 0.216 & 2.51 & 0.900 \\
\hline & 32.0 & 1.96 & 0.214 & 2.50 & 0.500 & 1.96 & 0.218 & 2.50 & 0.510 \\
\hline
\end{tabular}


Hydrologic-Property Measurements of UZ-N37 Core Samples at Yucca Mountain, Nevada--Continued

\begin{tabular}{|c|c|c|c|c|c|c|c|c|c|}
\hline \multirow[b]{2}{*}{$\begin{array}{l}\text { Depth } \\
\text { (m) }\end{array}$} & \multicolumn{4}{|c|}{ RH oven-drying calculations } & \multicolumn{4}{|c|}{$105^{\circ} \mathrm{C}$ oven-drying calculations } & \\
\hline & $\begin{array}{l}\text { Dry bulk } \\
\text { density } \\
\left(\mathrm{g} / \mathrm{cm}^{3}\right)\end{array}$ & $\begin{array}{l}\text { Porosity } \\
\left(\mathrm{cm}^{3} / \mathrm{cm}^{3}\right)\end{array}$ & $\begin{array}{l}\text { Particle } \\
\text { density } \\
\left(\mathrm{g} / \mathrm{cm}^{3}\right)\end{array}$ & $\begin{array}{l}\text { Saturation } \\
\left(\mathrm{cm}^{3} / \mathrm{cm}^{3}\right)\end{array}$ & $\begin{array}{l}\text { Dry bulk } \\
\text { density } \\
\left(\mathrm{g} / \mathrm{cm}^{3}\right)\end{array}$ & $\begin{array}{l}\text { Porosity } \\
\left(\mathrm{cm}^{3} / \mathrm{cm}^{3}\right)\end{array}$ & $\begin{array}{l}\text { Particle } \\
\text { density } \\
\left(\mathrm{g} / \mathrm{cm}^{3}\right)\end{array}$ & $\begin{array}{l}\text { Saturation } \\
\left(\mathrm{cm}^{3} / \mathrm{cm}^{3}\right)\end{array}$ & \\
\hline 32.7 & 1.90 & 0.211 & 2.41 & 0.956 & 1.87 & 0.244 & 2.47 & 0.962 & \\
\hline 33.5 & 1.61 & 0.289 & 2.26 & 0.958 & 1.50 & 0.400 & 2.50 & 0.970 & \\
\hline 34.3 & 1.62 & 0.308 & 2.34 & 0.970 & 1.53 & 0.398 & 2.54 & 0.977 & \\
\hline 35.1 & 1.52 & 0.340 & 2.31 & 0.943 & 1.41 & 0.448 & 2.56 & 0.956 & \\
\hline 35.8 & 1.45 & 0.374 & 2.32 & 0.395 & 1.37 & 0.455 & 2.51 & 0.503 & \\
\hline 36.5 & 1.42 & 0.396 & 2.34 & 0.376 & 1.36 & 0.456 & 2.49 & 0.458 & \\
\hline 37.3 & 1.33 & 0.433 & 2.35 & 0.338 & 1.29 & 0.470 & 2.44 & 0.389 & \\
\hline 38.1 & 1.25 & 0.460 & 2.32 & 0.341 & 1.21 & 0.507 & 2.45 & 0.403 & \\
\hline 38.8 & 1.32 & 0.433 & 2.33 & 0.507 & 1.27 & 0.484 & 2.46 & 0.559 & \\
\hline 39.6 & 1.17 & 0.497 & 2.32 & 0.368 & 1.12 & 0.542 & 2.45 & 0.420 & ** \\
\hline 41.1 & 1.56 & 0.342 & 2.36 & 0.355 & 1.51 & 0.385 & 2.46 & 0.427 & $* *$ \\
\hline 45.3 & 1.21 & 0.485 & 2.35 & 0.228 & 1.18 & 0.517 & 2.44 & 0.277 & $* *$ \\
\hline 46.5 & 1.17 & 0.492 & 2.30 & 0.241 & 1.15 & 0.514 & 2.36 & 0.272 & $* *$ \\
\hline 47.6 & 1.25 & 0.467 & 2.35 & 0.193 & 1.22 & 0.497 & 2.43 & 0.241 & $* *$ \\
\hline 49.4 & 1.06 & 0.514 & 2.18 & 0.187 & 1.02 & 0.551 & 2.28 & 0.243 & $* *$ \\
\hline 50.6 & 1.16 & 0.492 & 2.30 & 0.208 & 1.14 & 0.513 & 2.35 & 0.239 & $* *$ \\
\hline 51.6 & 0.98 & 0.565 & 2.25 & 0.159 & 0.97 & 0.571 & 2.27 & 0.174 & $* *$ \\
\hline 51.6 & 0.98 & 0.565 & 2.25 & & 0.97 & 0.571 & 2.27 & & $* *$ \\
\hline 52.3 & 1.03 & 0.547 & 2.26 & & 0.99 & 0.579 & 2.36 & & $* *$ \\
\hline 52.6 & 1.05 & 0.535 & 2.27 & 0.190 & 1.05 & 0.539 & 2.28 & 0.202 & $* *$ \\
\hline 52.6 & 1.05 & 0.535 & 2.27 & & 1.05 & 0.539 & 2.28 & & $* *$ \\
\hline 53.9 & 0.88 & 0.613 & 2.29 & 0.344 & 0.88 & 0.623 & 2.32 & 0.352 & $* *$ \\
\hline 53.9 & 0.88 & 0.613 & 2.29 & & 0.88 & 0.623 & 2.32 & & $* *$ \\
\hline 54.2 & 1.11 & 0.512 & 2.27 & 0.196 & 1.09 & 0.528 & 2.31 & 0.195 & $* *$ \\
\hline 54.2 & 1.11 & 0.512 & 2.27 & & 1.09 & 0.528 & 2.31 & & $* *$ \\
\hline 54.8 & 1.15 & 0.498 & 2.29 & 0.176 & 1.14 & 0.507 & 2.31 & 0.186 & $* *$ \\
\hline 54.8 & 1.15 & 0.498 & 2.29 & & 1.14 & 0.507 & 2.31 & & $* *$ \\
\hline 55.5 & 1.05 & 0.555 & 2.35 & 0.182 & & & & & $* *$ \\
\hline 55.5 & 1.05 & 0.555 & 2.35 & & & & & & $* *$ \\
\hline 57.1 & 1.20 & 0.460 & 2.22 & 0.237 & 1.19 & 0.463 & 2.22 & 0.243 & $* *$ \\
\hline 57.9 & 1.14 & 0.505 & 2.31 & 0.221 & 1.14 & 0.510 & 2.32 & 0.230 & $* *$ \\
\hline
\end{tabular}


Hydrologic-Property Measurements of UZ-N37 Core Samples at Yucca Mountain, Nevada--Continued

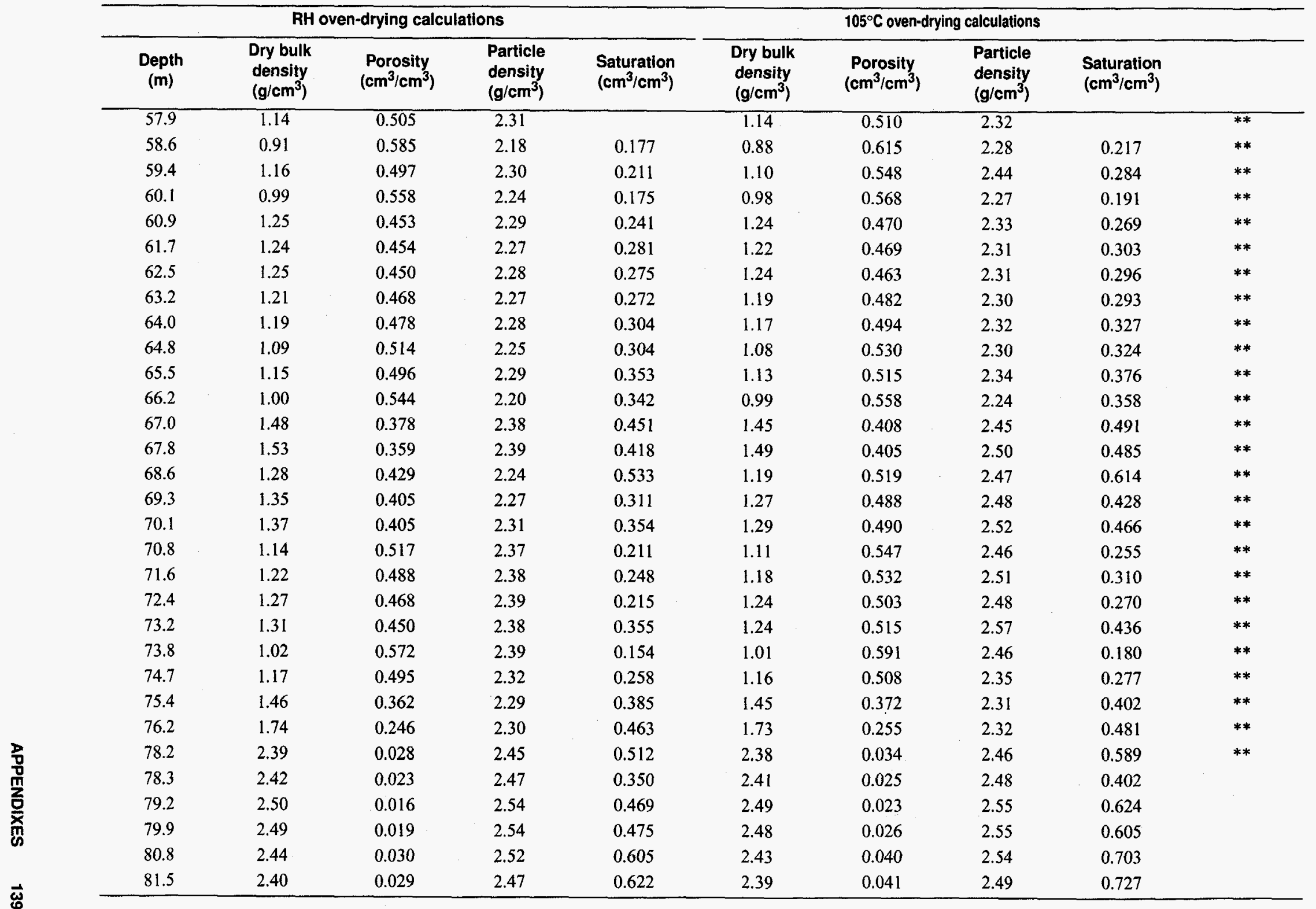


Hydrologic-Property Measurements of UZ-N53 Core Samples at Yucca Mountain, Nevada

[RH, relative humidity; ${ }^{\circ} \mathrm{C}$, degree Celsius; m, meter; $\mathrm{g} / \mathrm{cm}^{3}$, gram per cubic centimeter; $\mathrm{cm}^{3} / \mathrm{cm}^{3}$, cubic centimeter per cubic centimeter]

\begin{tabular}{|c|c|c|c|c|c|c|c|c|}
\hline \multicolumn{5}{|c|}{ RH oven-drying calculations } & \multicolumn{4}{|c|}{$105^{\circ} \mathrm{C}$ oven-drying calculations } \\
\hline $\begin{array}{c}\text { Depth } \\
(\mathrm{m})\end{array}$ & $\begin{array}{l}\text { Dry bulk } \\
\text { density } \\
\left(\mathbf{g} / \mathrm{cm}^{3}\right)\end{array}$ & $\begin{array}{l}\text { Porosity } \\
\left(\mathrm{cm}^{3} / \mathrm{cm}^{3}\right)\end{array}$ & $\begin{array}{l}\text { Particle } \\
\text { density } \\
\left(\mathrm{g} / \mathrm{cm}^{3}\right)\end{array}$ & $\begin{array}{l}\text { Saturation } \\
\left(\mathrm{cm}^{3} / \mathrm{cm}^{3}\right)\end{array}$ & $\begin{array}{l}\text { Dry bulk } \\
\text { density } \\
\left(\mathrm{g} / \mathrm{cm}^{3}\right)\end{array}$ & $\begin{array}{c}\text { Porosity } \\
\left(\mathrm{cm}^{3} / \mathrm{cm}^{3}\right)\end{array}$ & $\begin{array}{l}\text { Particle } \\
\text { density } \\
\left(\mathrm{g} / \mathrm{cm}^{3}\right)\end{array}$ & $\begin{array}{l}\text { Saturation } \\
\left(\mathrm{cm}^{3} / \mathrm{cm}^{3}\right)\end{array}$ \\
\hline 41.9 & 2.26 & 0.087 & 2.48 & 0.776 & 2.26 & 0.092 & 2.48 & 0.789 \\
\hline 42.7 & 2.28 & 0.066 & 2.45 & 0.818 & 2.28 & 0.069 & 2.45 & 0.826 \\
\hline 44.3 & 2.09 & 0.151 & 2.46 & 0.636 & 2.07 & 0.168 & 2.49 & 0.673 \\
\hline 45.0 & 1.81 & 0.219 & 2.32 & 0.969 & 1.70 & 0.335 & 2.55 & 0.980 \\
\hline 45.7 & 1.86 & 0.226 & 2.40 & 0.983 & 1.80 & 0.282 & 2.51 & 0.986 \\
\hline 46.6 & 1.92 & 0.182 & 2.35 & 0.980 & 1.85 & 0.248 & 2.46 & 0.985 \\
\hline 47.2 & 1.86 & 0.207 & 2.34 & 0.995 & 1.81 & 0.252 & 2.42 & 0.996 \\
\hline 48.0 & 1.63 & 0.280 & 2.27 & 0.993 & 1.55 & 0.360 & 2.43 & 0.995 \\
\hline 48.8 & 1.54 & 0.334 & 2.32 & 0.868 & 1.49 & 0.385 & 2.42 & 0.885 \\
\hline 49.9 & 1.46 & 0.369 & 2.31 & 0.748 & 1.43 & 0.397 & 2.37 & 0.766 \\
\hline 50.2 & 1.35 & 0.407 & 2.28 & 0.644 & 1.32 & 0.433 & 2.34 & 0.666 \\
\hline 51.0 & 1.31 & 0.415 & 2.23 & 0.406 & 1.29 & 0.433 & 2.27 & 0.430 \\
\hline 51.9 & 1.28 & 0.433 & 2.26 & 0.485 & 1.26 & 0.452 & 2.30 & 0.506 \\
\hline 52.6 & 1.39 & 0.386 & 2.25 & 0.544 & 1.36 & 0.407 & 2.30 & 0.568 \\
\hline 53.3 & 1.26 & 0.448 & 2.29 & 0.523 & 1.24 & 0.475 & 2.35 & 0.550 \\
\hline 54.0 & 1.32 & 0.397 & 2.18 & 0.436 & 1.29 & 0.421 & 2.23 & 0.467 \\
\hline 54.9 & 1.41 & 0.387 & 2.30 & 0.688 & 1.37 & 0.428 & 2.39 & 0.718 \\
\hline 55.5 & 1.53 & 0.344 & 2.34 & 0.423 & 1.51 & 0.368 & 2.39 & 0.460 \\
\hline 56.4 & 2.16 & 0.124 & 2.47 & 0.763 & 2.15 & 0.137 & 2.49 & 0.785 \\
\hline 57.2 & 1.55 & 0.344 & 2.37 & 0.499 & 1.51 & 0.382 & 2.45 & 0.549 \\
\hline 57.9 & 1.48 & 0.358 & 2.30 & 0.456 & 1.45 & 0.388 & 2.37 & 0.499 \\
\hline 58.5 & 1.45 & 0.376 & 2.32 & 0.429 & 1.42 & 0.400 & 2.37 & 0.464 \\
\hline 59.4 & 1.14 & 0.505 & 2.30 & 0.347 & 1.13 & 0.518 & 2.34 & 0.363 \\
\hline 60.1 & 1.44 & 0.380 & 2.32 & 0.393 & 1.41 & 0.405 & 2.37 & 0.431 \\
\hline 61.0 & 1.22 & 0.478 & 2.34 & 0.350 & 1.19 & 0.515 & 2.44 & 0.397 \\
\hline 61.7 & 1.20 & 0.465 & 2.24 & 0.389 & 1.15 & 0.513 & 2.36 & 0.446 \\
\hline 62.5 & 0.95 & 0.560 & 2.16 & 0.243 & 0.94 & 0.571 & 2.19 & 0.258 \\
\hline 63.3 & 1.11 & 0.509 & 2.27 & 0.261 & 1.07 & 0.549 & 2.38 & 0.314 \\
\hline
\end{tabular}


Hydrologic-Property Measurements of UZ-N53 Core Samples at Yucca Mountain, Nevada--Continued

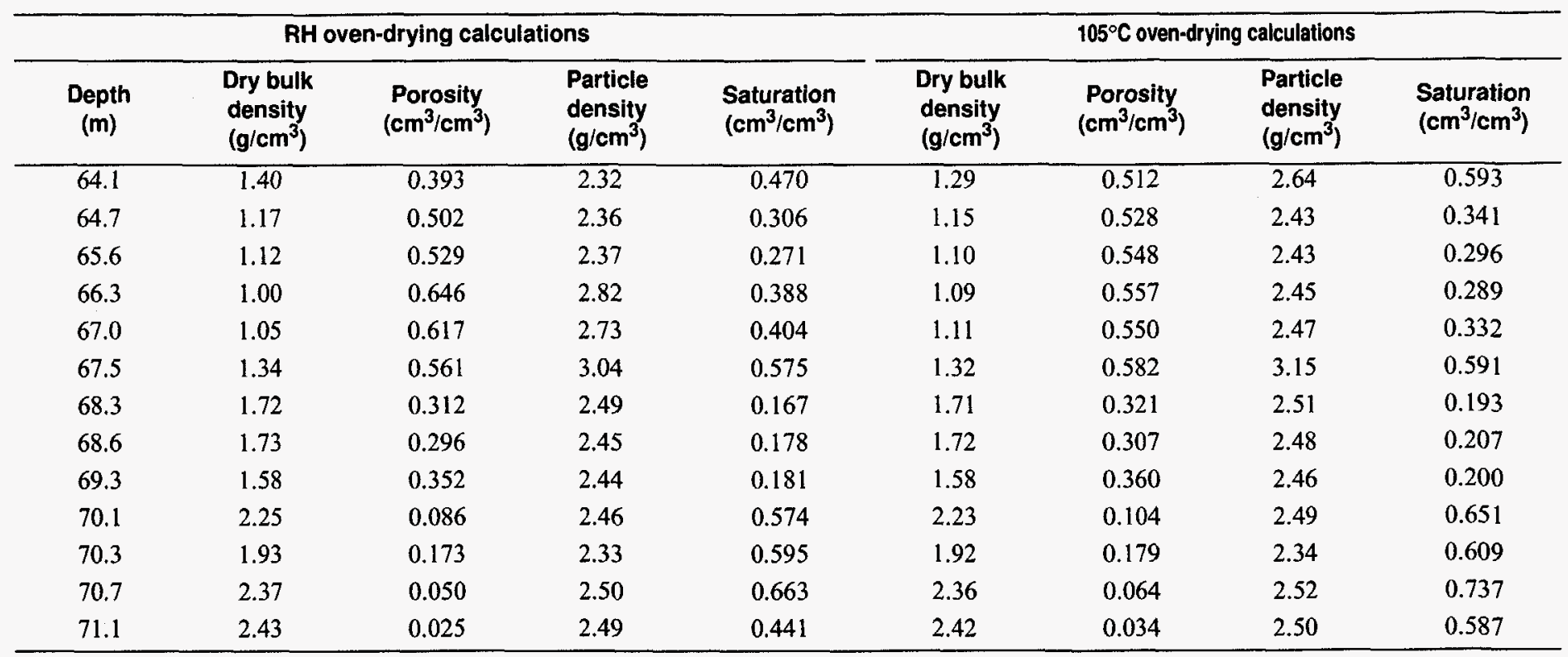

Hydrologic-Property Measurements of UZ-N54 Core Samples at Yucca Mountain, Nevada

$\left[\mathrm{RH}\right.$, relative humidity; ${ }^{\circ} \mathrm{C}$, degree Celsius; $\mathrm{m}$, meter; $\mathrm{g} / \mathrm{cm}^{3}$, gram per cubic centimeter; $\mathrm{cm}^{3} / \mathrm{cm}^{3}$, cubic centimeter per cubic centimeter]

\begin{tabular}{|c|c|c|c|c|c|c|c|c|}
\hline \multicolumn{5}{|c|}{ RH oven-drying calculations } & \multicolumn{4}{|c|}{$105^{\circ} \mathrm{C}$ oven-drying calculations } \\
\hline $\begin{array}{l}\text { Depth } \\
\text { (m) }\end{array}$ & $\begin{array}{l}\text { Dry bulk } \\
\text { density } \\
\left(\mathrm{g} / \mathrm{cm}^{3}\right)\end{array}$ & $\begin{array}{l}\text { Porosity } \\
\left(\mathrm{cm}^{3} / \mathrm{cm}^{3}\right)\end{array}$ & $\begin{array}{l}\text { Particle } \\
\text { density } \\
\left(\mathrm{g} / \mathrm{cm}^{3}\right)\end{array}$ & $\begin{array}{l}\text { Saturation } \\
\left(\mathrm{cm}^{3} / \mathrm{cm}^{3}\right)\end{array}$ & $\begin{array}{c}\text { Dry bulk } \\
\text { density } \\
\left(\mathrm{g} / \mathrm{cm}^{3}\right)\end{array}$ & $\begin{array}{l}\text { Porosity } \\
\left(\mathrm{cm}^{3} / \mathrm{cm}^{3}\right)\end{array}$ & $\begin{array}{l}\text { Particle } \\
\text { density } \\
\left(\mathrm{g} / \mathrm{cm}^{3}\right)\end{array}$ & $\begin{array}{l}\text { Saturation } \\
\left(\mathrm{cm}^{3} / \mathrm{cm}^{3}\right)\end{array}$ \\
\hline 38.8 & 2.31 & 0.062 & 2.47 & 0.745 & 2.30 & 0.072 & 2.48 & 0.780 \\
\hline 39.7 & 2.27 & 0.093 & 2.50 & 0.848 & 2.26 & 0.105 & 2.52 & 0.865 \\
\hline 40.4 & 2.24 & 0.089 & 2.46 & 0.754 & 2.22 & 0.108 & 2.49 & 0.797 \\
\hline 41.9 & 2.10 & 0.152 & 2.48 & 0.755 & 2.09 & 0.164 & 2.50 & 0.773 \\
\hline 42.8 & 1.95 & 0.215 & 2.49 & 0.797 & 1.95 & 0.220 & 2.50 & 0.801 \\
\hline 43.4 & 2.03 & 0.181 & 2.48 & 0.891 & 2.02 & 0.192 & 2.50 & 0.898 \\
\hline
\end{tabular}


Hydrologic-Property Measurements of UZ-N54 Core Samples at Yucca Mountain, Nevada--Continued

\begin{tabular}{|c|c|c|c|c|c|c|c|c|}
\hline \multicolumn{5}{|c|}{ RH oven-drying calculations } & \multicolumn{4}{|c|}{$105^{\circ} \mathrm{C}$ oven-drying calculations } \\
\hline $\begin{array}{l}\text { Depth } \\
(\mathrm{m})\end{array}$ & $\begin{array}{l}\text { Dry bulk } \\
\text { density } \\
\left(\mathrm{g} / \mathrm{cm}^{3}\right)\end{array}$ & $\begin{array}{l}\text { Porosity } \\
\left(\mathrm{cm}^{3} / \mathrm{cm}^{3}\right)\end{array}$ & $\begin{array}{l}\text { Particle } \\
\text { density } \\
\left(\mathrm{g} / \mathrm{cm}^{3}\right)\end{array}$ & $\begin{array}{l}\text { Saturation } \\
\left(\mathrm{cm}^{3} / \mathrm{cm}^{3}\right)\end{array}$ & $\begin{array}{l}\text { Dry bulk } \\
\text { density } \\
\left(\mathrm{g} / \mathrm{cm}^{3}\right)\end{array}$ & $\begin{array}{l}\text { Porosity } \\
\left(\mathrm{cm}^{3} / \mathrm{cm}^{3}\right)\end{array}$ & $\begin{array}{l}\text { Particle } \\
\text { density } \\
\left(\mathrm{g} / \mathrm{cm}^{3}\right)\end{array}$ & $\begin{array}{l}\text { Saturation } \\
\left(\mathrm{cm}^{3} / \mathrm{cm}^{3}\right)\end{array}$ \\
\hline 44.3 & 1.79 & 0.250 & 2.39 & 0.821 & 1.72 & 0.326 & 2.55 & 0.863 \\
\hline 45.0 & 1.85 & 0.214 & 2.35 & 0.979 & 1.78 & 0.279 & 2.47 & 0.984 \\
\hline 45.7 & 1.76 & 0.246 & 2.34 & 0.971 & 1.71 & 0.300 & 2.44 & 0.976 \\
\hline 46.5 & 1.63 & 0.299 & 2.33 & 0.969 & 1.57 & 0.358 & 2.45 & 0.974 \\
\hline 47.3 & 1.50 & 0.348 & 2.30 & 0.905 & 1.45 & 0.401 & 2.42 & 0.917 \\
\hline 47.5 & 1.65 & 0.303 & 2.37 & 0.808 & 1.62 & 0.337 & 2.44 & 0.827 \\
\hline 48.0 & 1.48 & 0.353 & 2.29 & 0.508 & 1.46 & 0.375 & 2.33 & 0.537 \\
\hline 48.7 & 1.40 & 0.386 & 2.28 & 0.390 & 1.38 & 0.409 & 2.33 & 0.424 \\
\hline 49.5 & 1.33 & 0.416 & 2.28 & 0.358 & 1.31 & 0.436 & 2.32 & 0.389 \\
\hline 50.3 & 1.35 & 0.408 & 2.28 & 0.493 & 1.33 & 0.431 & 2.34 & 0.520 \\
\hline 50.9 & 1.33 & 0.417 & 2.28 & 0.399 & 1.30 & 0.442 & 2.34 & 0.433 \\
\hline 51.7 & 1.36 & 0.395 & 2.24 & 0.502 & 1.32 & 0.435 & 2.33 & 0.547 \\
\hline 51.8 & 1.31 & 0.424 & 2.27 & 0.430 & 1.28 & 0.452 & 2.34 & 0.466 \\
\hline 52.5 & 1.27 & 0.446 & 2.29 & 0.343 & 1.24 & 0.472 & 2.35 & 0.379 \\
\hline 53.3 & 1.26 & 0.452 & 2.30 & 0.510 & 1.24 & 0.474 & 2.35 & 0.533 \\
\hline 54.9 & 1.26 & 0.469 & 2.37 & 0.456 & 1.24 & 0.490 & 2.42 & 0.479 \\
\hline 55.6 & 1.32 & 0.434 & 2.33 & 0.523 & 1.30 & 0.456 & 2.39 & 0.547 \\
\hline 56.4 & 1.55 & 0.340 & 2.34 & 0.531 & 1.49 & 0.401 & 2.48 & 0.603 \\
\hline 57.1 & 1.49 & 0.362 & 2.34 & 0.457 & 1.45 & 0.406 & 2.44 & 0.517 \\
\hline 57.9 & 1.11 & 0.528 & 2.36 & 0.435 & 1.08 & 0.556 & 2.44 & 0.463 \\
\hline 58.7 & 1.45 & 0.387 & 2.36 & 0.479 & 1.40 & 0.434 & 2.47 & 0.535 \\
\hline 59.4 & 1.31 & 0.433 & 2.31 & 0.395 & 1.28 & 0.463 & 2.38 & 0.434 \\
\hline 60.2 & 1.15 & 0.502 & 2.32 & 0.512 & 1.08 & 0.574 & 2.54 & 0.573 \\
\hline 60.9 & 1.07 & 0.528 & 2.28 & 0.289 & 1.06 & 0.545 & 2.32 & 0.311 \\
\hline 61.7 & 1.04 & 0.563 & 2.39 & 0.320 & 1.03 & 0.578 & 2.43 & 0.337 \\
\hline 62.7 & 1.09 & 0.550 & 2.42 & 0.284 & 1.07 & 0.571 & 2.49 & 0.312 \\
\hline 63.4 & 1.06 & 0.567 & 2.44 & 0.295 & 1.04 & 0.584 & 2.50 & 0.316 \\
\hline
\end{tabular}


Hydrologic-Property Measurements of UZ-N54 Core Samples at Yucca Mountain, Nevada--Continued

\begin{tabular}{|c|c|c|c|c|c|c|c|c|}
\hline \multicolumn{5}{|c|}{ RH oven-drying calculations } & \multicolumn{4}{|c|}{$105^{\circ} \mathrm{C}$ oven-drying calculations } \\
\hline $\begin{array}{l}\text { Depth } \\
(\mathrm{m})\end{array}$ & $\begin{array}{l}\text { Dry bulk } \\
\text { density } \\
\left(\mathbf{g} / \mathrm{cm}^{3}\right)\end{array}$ & $\begin{array}{l}\text { Porosity } \\
\left(\mathrm{cm}^{3} / \mathrm{cm}^{3}\right)\end{array}$ & $\begin{array}{l}\text { Particle } \\
\text { density } \\
\left(\mathrm{g} / \mathrm{cm}^{3}\right)\end{array}$ & $\begin{array}{l}\text { Saturation } \\
\left(\mathrm{cm}^{3} / \mathrm{cm}^{3}\right)\end{array}$ & $\begin{array}{l}\text { Dry bulk } \\
\text { density } \\
\left(\mathbf{g} / \mathrm{cm}^{3}\right)\end{array}$ & $\begin{array}{l}\text { Porosity } \\
\left(\mathrm{cm}^{3} / \mathrm{cm}^{3}\right)\end{array}$ & $\begin{array}{l}\text { Particle } \\
\text { density } \\
\left(\mathrm{g} / \mathrm{cm}^{3}\right)\end{array}$ & $\begin{array}{l}\text { Saturation } \\
\left(\mathrm{cm}^{3} / \mathrm{cm}^{3}\right)\end{array}$ \\
\hline$\overline{64.2}$ & 1.02 & 0.574 & 2.40 & 0.309 & 1.00 & 0.600 & 2.50 & 0.339 \\
\hline 64.7 & 1.07 & 0.553 & 2.41 & 0.353 & 1.05 & 0.581 & 2.50 & 0.384 \\
\hline 65.5 & 1.19 & 0.502 & 2.39 & 0.526 & 1.14 & 0.554 & 2.55 & 0.571 \\
\hline 66.3 & 1.43 & 0.423 & 2.48 & 0.456 & 1.38 & 0.472 & 2.62 & 0.513 \\
\hline 67.3 & 1.65 & 0.310 & 2.39 & 0.486 & 1.57 & 0.391 & 2.57 & 0.592 \\
\hline 68.8 & 1.47 & 0.399 & 2.45 & 0.090 & 1.47 & 0.405 & 2.47 & 0.104 \\
\hline 69.4 & 1.38 & 0.448 & 2.49 & 0.516 & 1.36 & 0.464 & 2.54 & 0.533 \\
\hline 70.1 & 2.05 & 0.200 & 2.57 & 0.642 & 1.98 & 0.271 & 2.72 & 0.735 \\
\hline 70.9 & 2.28 & 0.090 & 2.51 & 0.526 & 2.24 & 0.127 & 2.57 & 0.663 \\
\hline 71.6 & 2.39 & 0.035 & 2.48 & 0.474 & 2.37 & 0.055 & 2.51 & 0.665 \\
\hline 73.2 & 2.17 & 0.150 & 2.56 & 0.199 & 2.16 & 0.160 & 2.58 & 0.246 \\
\hline 73.9 & 2.25 & 0.121 & 2.56 & 0.296 & 2.24 & 0.131 & 2.58 & 0.351 \\
\hline 74.4 & 2.25 & 0.123 & 2.56 & 0.382 & 2.24 & 0.133 & 2.58 & 0.427 \\
\hline
\end{tabular}

Hydrologic-Property Measurements of UZ-N55 Core Samples at Yucca Mountain, Nevada

[RH, relative humidity; ${ }^{\circ} \mathrm{C}$, degree Celsius; $\mathrm{m}$, meter; $\mathrm{g} / \mathrm{cm}^{3}$, gram per cubic centimeter; $\mathrm{cm}^{3} / \mathrm{cm}^{3}$, cubic centimeter per cubic centimeter]

\begin{tabular}{|c|c|c|c|c|c|c|c|c|}
\hline \multicolumn{5}{|c|}{ RH oven-drying calculations } & \multicolumn{4}{|c|}{$105^{\circ} \mathrm{C}$ oven-drying calculations } \\
\hline $\begin{array}{c}\text { Depth } \\
(\mathrm{m})\end{array}$ & $\begin{array}{l}\text { Dry bulk } \\
\text { density } \\
\left(\mathrm{g} / \mathrm{cm}^{3}\right)\end{array}$ & $\begin{array}{l}\text { Porosity } \\
\left(\mathrm{cm}^{3} / \mathrm{cm}^{3}\right)\end{array}$ & $\begin{array}{l}\text { Particle } \\
\text { density } \\
\left(\mathrm{g} / \mathrm{cm}^{3}\right)\end{array}$ & $\begin{array}{l}\text { Saturation } \\
\left(\mathrm{cm}^{3} / \mathrm{cm}^{3}\right)\end{array}$ & $\begin{array}{l}\text { Dry bulk } \\
\text { density } \\
\left(\mathrm{g} / \mathrm{cm}^{3}\right)\end{array}$ & $\begin{array}{l}\text { Porosity } \\
\left(\mathrm{cm}^{3} / \mathrm{cm}^{3}\right)\end{array}$ & $\begin{array}{l}\text { Particle } \\
\text { density } \\
\left(\mathbf{g} / \mathrm{cm}^{3}\right)\end{array}$ & $\begin{array}{l}\text { Saturation } \\
\left(\mathrm{cm}^{3} / \mathrm{cm}^{3}\right)\end{array}$ \\
\hline 67.1 & 1.32 & 0.430 & 2.32 & 0.367 & 1.30 & 0.452 & 2.37 & 0.398 \\
\hline 67.8 & 1.46 & 0.377 & 2.35 & 0.344 & 1.44 & 0.402 & 2.40 & 0.385 \\
\hline 68.6 & 1.27 & 0.459 & 2.34 & 0.476 & 1.24 & 0.487 & 2.41 & 0.506 \\
\hline 69.3 & 1.28 & 0.464 & 2.38 & 0.383 & 1.24 & 0.501 & 2.48 & 0.428 \\
\hline 70.0 & 1.24 & 0.470 & 2.33 & 0.326 & 1.21 & 0.492 & 2.39 & 0.356 \\
\hline 70.9 & 1.32 & 0.440 & 2.35 & 0.393 & 1.29 & 0.466 & 2.42 & 0.427 \\
\hline
\end{tabular}


Hydrologic-Property Measurements of UZ-N55 Core Samples at Yucca Mountain, Nevada--Continued

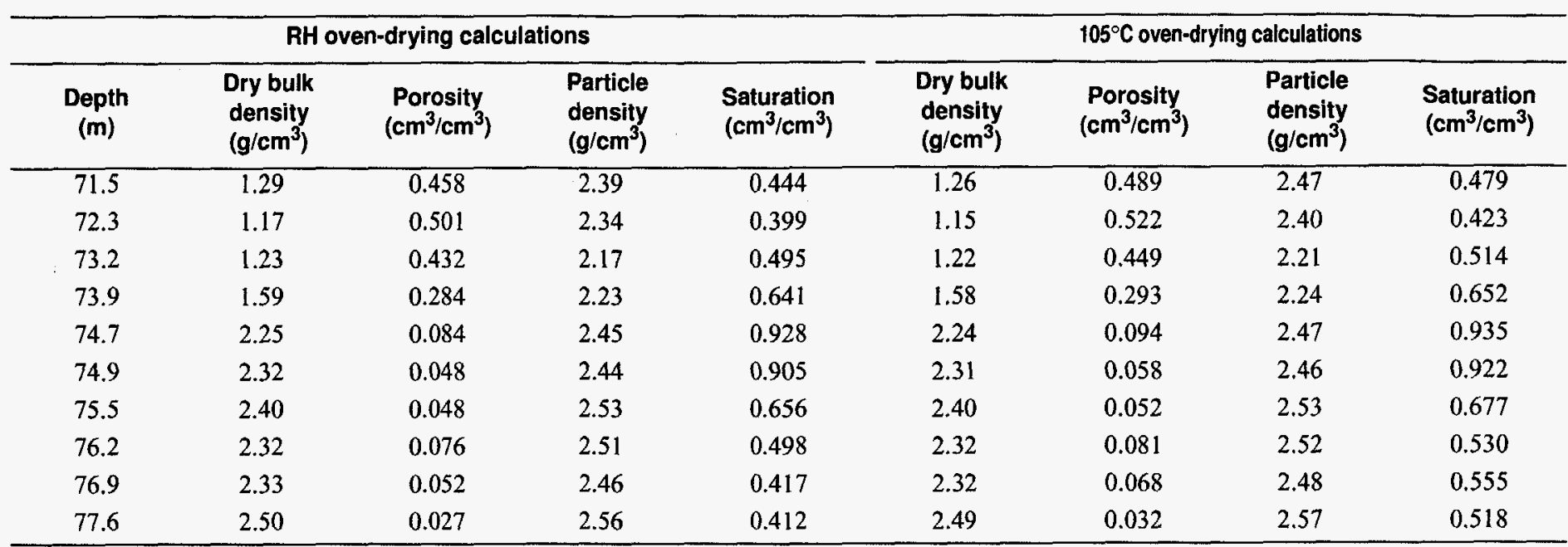

Hydrologic-Property Measurements of SD-9 Core Samples at Yucca Mountain, Nevada

[RH, relative humidity; ${ }^{\circ} \mathrm{C}$, degree Celsius; $\mathrm{m}$, meter; $\mathrm{g} / \mathrm{cm}^{3}$, gram per cubic centimeter; $\mathrm{cm}^{3} / \mathrm{cm}^{3}$, cubic centimeter per cubic centimeter]

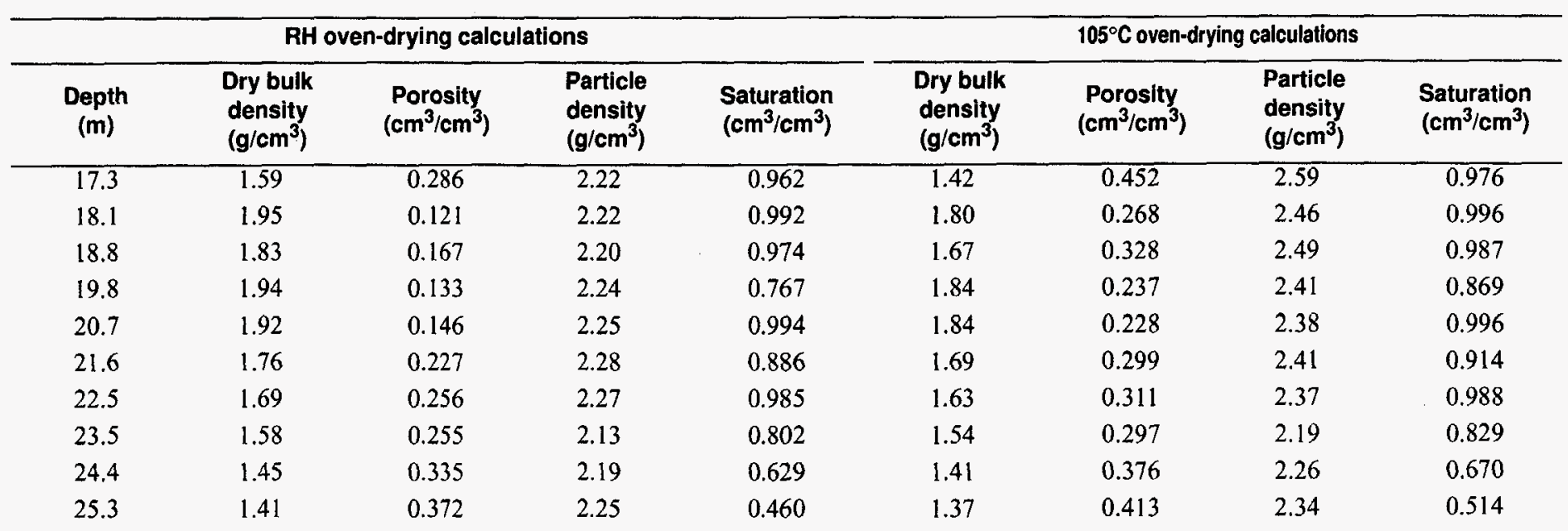


Hydrologic-Property Measurements of SD-9 Core Samples at Yucca Mountain, Nevada--Continued

\begin{tabular}{|c|c|c|c|c|c|c|c|c|}
\hline \multicolumn{5}{|c|}{ RH oven-drying calculations } & \multicolumn{4}{|c|}{$105^{\circ} \mathrm{C}$ oven-drying calculations } \\
\hline $\begin{array}{l}\text { Depth } \\
\text { (m) }\end{array}$ & $\begin{array}{l}\text { Dry bulk } \\
\text { density } \\
\left(\mathrm{g} / \mathrm{cm}^{3}\right)\end{array}$ & $\begin{array}{c}\text { Porosity } \\
\left(\mathrm{cm}^{3} / \mathrm{cm}^{3}\right)\end{array}$ & $\begin{array}{l}\text { Particle } \\
\text { density } \\
\left(\mathrm{g} / \mathrm{cm}^{3}\right)\end{array}$ & $\begin{array}{l}\text { Saturation } \\
\left(\mathrm{cm}^{3} / \mathrm{cm}^{3}\right)\end{array}$ & $\begin{array}{c}\text { Dry bulk } \\
\text { density } \\
\left(\mathrm{g} / \mathrm{cm}^{3}\right)\end{array}$ & $\begin{array}{l}\text { Porosity } \\
\left(\mathrm{cm}^{3} / \mathrm{cm}^{3}\right)\end{array}$ & $\begin{array}{l}\text { Particle } \\
\text { density } \\
\left(\mathrm{g} / \mathrm{cm}^{3}\right)\end{array}$ & $\begin{array}{l}\text { Saturation } \\
\left(\mathrm{cm}^{3} / \mathrm{cm}^{3}\right)\end{array}$ \\
\hline 26.3 & 1.41 & 0.362 & 2.21 & 0.495 & 1.37 & 0.398 & 2.28 & 0.540 \\
\hline 26.9 & 1.43 & 0.351 & 2.20 & 0.494 & 1.38 & 0.396 & 2.28 & 0.551 \\
\hline 28.9 & 0.97 & 0.569 & 2.24 & 0.566 & 0.92 & 0.619 & 2.40 & 0.601 \\
\hline 31.7 & 1.38 & 0.367 & 2.18 & 0.383 & 1.36 & 0.387 & 2.22 & 0.415 \\
\hline 32.7 & 1.40 & 0.363 & 2.19 & 0.465 & 1.37 & 0.387 & 2.24 & 0.497 \\
\hline 33.6 & 1.47 & 0.310 & 2.13 & 0.592 & 1.45 & 0.332 & 2.17 & 0.619 \\
\hline 34.5 & 1.51 & 0.292 & 2.13 & 0.638 & 1.49 & 0.311 & 2.16 & 0.660 \\
\hline 35.3 & 1.53 & 0.262 & 2.07 & 0.618 & 1.50 & 0.289 & 2.11 & 0.654 \\
\hline 40.7 & 1.42 & 0.335 & 2.13 & 0.395 & 1.39 & 0.357 & 2.17 & 0.432 \\
\hline 41.8 & 1.43 & 0.347 & 2.19 & 0.370 & 1.40 & 0.373 & 2.24 & 0.415 \\
\hline 42.8 & 1.40 & 0.357 & 2.18 & 0.345 & 1.37 & 0.384 & 2.23 & 0.390 \\
\hline 43.5 & 1.59 & 0.310 & 2.30 & 0.448 & 1.56 & 0.337 & 2.35 & 0.491 \\
\hline 46.4 & 1.54 & 0.308 & 2.23 & 0.409 & 1.50 & 0.353 & 2.32 & 0.484 \\
\hline 47.2 & 1.31 & 0.412 & 2.23 & 0.423 & 1.23 & 0.493 & 2.42 & 0.518 \\
\hline 48.1 & 1.14 & 0.477 & 2.19 & 0.350 & 1.10 & 0.518 & 2.29 & 0.401 \\
\hline 49.0 & 1.09 & 0.490 & 2.13 & 0.294 & 1.07 & 0.508 & 2.17 & 0.320 \\
\hline 49.9 & 1.09 & 0.456 & 2.01 & 0.281 & 1.08 & 0.470 & 2.04 & 0.302 \\
\hline 51.7 & 1.19 & 0.427 & 2.07 & 0.325 & 1.17 & 0.440 & 2.10 & 0.345 \\
\hline 52.7 & 1.23 & 0.411 & 2.09 & 0.318 & 1.22 & 0.426 & 2.12 & 0.342 \\
\hline 67.2 & 1.17 & 0.410 & 1.99 & 0.364 & 1.15 & 0.429 & 2.02 & 0.392 \\
\hline
\end{tabular}


Hydrologic-Property Measurements of SD-9 Core Samples at Yucca Mountain, Nevada--Continued

\begin{tabular}{|c|c|c|c|c|c|c|c|c|}
\hline \multicolumn{5}{|c|}{ RH oven-drying calculations } & \multicolumn{4}{|c|}{$105^{\circ} \mathrm{C}$ oven-drying calculations } \\
\hline $\begin{array}{c}\text { Depth } \\
\text { (m) }\end{array}$ & $\begin{array}{l}\text { Dry bulk } \\
\text { density } \\
\left(\mathrm{g} / \mathrm{cm}^{3}\right)\end{array}$ & $\begin{array}{c}\text { Porosity } \\
\left(\mathrm{cm}^{3} / \mathrm{cm}^{3}\right)\end{array}$ & $\begin{array}{l}\text { Particle } \\
\text { density } \\
\left(\mathrm{g} / \mathrm{cm}^{3}\right)\end{array}$ & $\begin{array}{l}\text { Saturation } \\
\left(\mathrm{cm}^{3} / \mathrm{cm}^{3}\right)\end{array}$ & $\begin{array}{l}\text { Dry bulk } \\
\text { density } \\
\left(\mathrm{g} / \mathrm{cm}^{3}\right)\end{array}$ & $\begin{array}{l}\text { Porosity } \\
\left(\mathrm{cm}^{3} / \mathrm{cm}^{3}\right)\end{array}$ & $\begin{array}{l}\text { Particle } \\
\text { density } \\
\left(\mathrm{g} / \mathrm{cm}^{3}\right)\end{array}$ & $\begin{array}{l}\text { Saturation } \\
\left(\mathrm{cm}^{3} / \mathrm{cm}^{3}\right)\end{array}$ \\
\hline 68.3 & 1.10 & 0.452 & 2.01 & 0.305 & 1.08 & 0.478 & 2.07 & 0.344 \\
\hline 70.1 & 1.40 & 0.347 & 2.15 & 0.269 & 1.36 & 0.389 & 2.23 & 0.347 \\
\hline 71.0 & 1.13 & 0.478 & 2.16 & 0.254 & 1.09 & 0.512 & 2.24 & 0.305 \\
\hline 74.9 & 0.98 & 0.501 & 1.97 & 0.235 & 0.97 & 0.509 & 1.99 & 0.248 \\
\hline 75.5 & 1.06 & 0.516 & 2.20 & 0.225 & 1.04 & 0.539 & 2.26 & 0.258 \\
\hline 76.5 & 1.06 & 0.509 & 2.17 & 0.229 & 1.05 & 0.527 & 2.21 & 0.256 \\
\hline 78.3 & 1.18 & 0.480 & 2.28 & 0.337 & 1.14 & 0.520 & 2.38 & 0.388 \\
\hline 79.3 & 1.16 & 0.479 & 2.22 & 0.316 & 1.10 & 0.540 & 2.38 & 0.394 \\
\hline 84.7 & 2.50 & 0.011 & 2.52 & 0.611 & 2.49 & 0.022 & 2.54 & 0.802 \\
\hline 85.5 & 2.46 & 0.015 & 2.50 & 0.451 & 2.44 & 0.031 & 2.52 & 0.722 \\
\hline
\end{tabular}

Hydrologic-Property Measurements of SD-12 Core Samples at Yucca Mountain, Nevada

[RH, relative humidity; ${ }^{\circ} \mathrm{C}$, degree Celsius; $\mathrm{m}$, meter; $\mathrm{g} / \mathrm{cm}^{3}$, gram per cubic centimeter; $\mathrm{cm}^{3} / \mathrm{cm}^{3}$, cubic centimeter per cubic centimeter]

\begin{tabular}{|c|c|c|c|c|c|c|c|c|}
\hline \multicolumn{5}{|c|}{ RH oven-drying calculations } & \multicolumn{4}{|c|}{$105^{\circ} \mathrm{C}$ oven-drying calculations } \\
\hline $\begin{array}{l}\text { Depth } \\
\text { (m) }\end{array}$ & $\begin{array}{l}\text { Dry bulk } \\
\text { density } \\
\left(\mathrm{g} / \mathrm{cm}^{3}\right)\end{array}$ & $\begin{array}{l}\text { Porosity } \\
\left(\mathrm{cm}^{3} / \mathrm{cm}^{3}\right)\end{array}$ & $\begin{array}{l}\text { Particle } \\
\text { density } \\
\left(\mathrm{g} / \mathrm{cm}^{3}\right)\end{array}$ & $\begin{array}{l}\text { Saturation } \\
\left(\mathrm{cm}^{3} / \mathrm{cm}^{3}\right)\end{array}$ & $\begin{array}{l}\text { Dry bulk } \\
\text { density } \\
\left(\mathrm{g} / \mathrm{cm}^{3}\right)\end{array}$ & $\begin{array}{l}\text { Porosity } \\
\left(\mathrm{cm}^{3} / \mathrm{cm}^{3}\right)\end{array}$ & $\begin{array}{l}\text { Particle } \\
\text { density } \\
\left(\mathrm{g} / \mathrm{cm}^{3}\right)\end{array}$ & $\begin{array}{l}\text { Saturation } \\
\left(\mathrm{cm}^{3} / \mathrm{cm}^{3}\right)\end{array}$ \\
\hline$\overline{68.2}$ & 2.33 & 0.055 & 2.46 & 0.634 & & & & \\
\hline 69.1 & 2.23 & 0.084 & 2.44 & 0.761 & & & & \\
\hline 71.2 & 2.17 & 0.105 & 2.42 & 0.682 & & & & \\
\hline 75.4 & 2.04 & 0.120 & 2.31 & 0.923 & & & & \\
\hline
\end{tabular}


Hydrologic-Property Measurements of SD-12 Core Samples at Yucca Mountain, Nevada--Continued

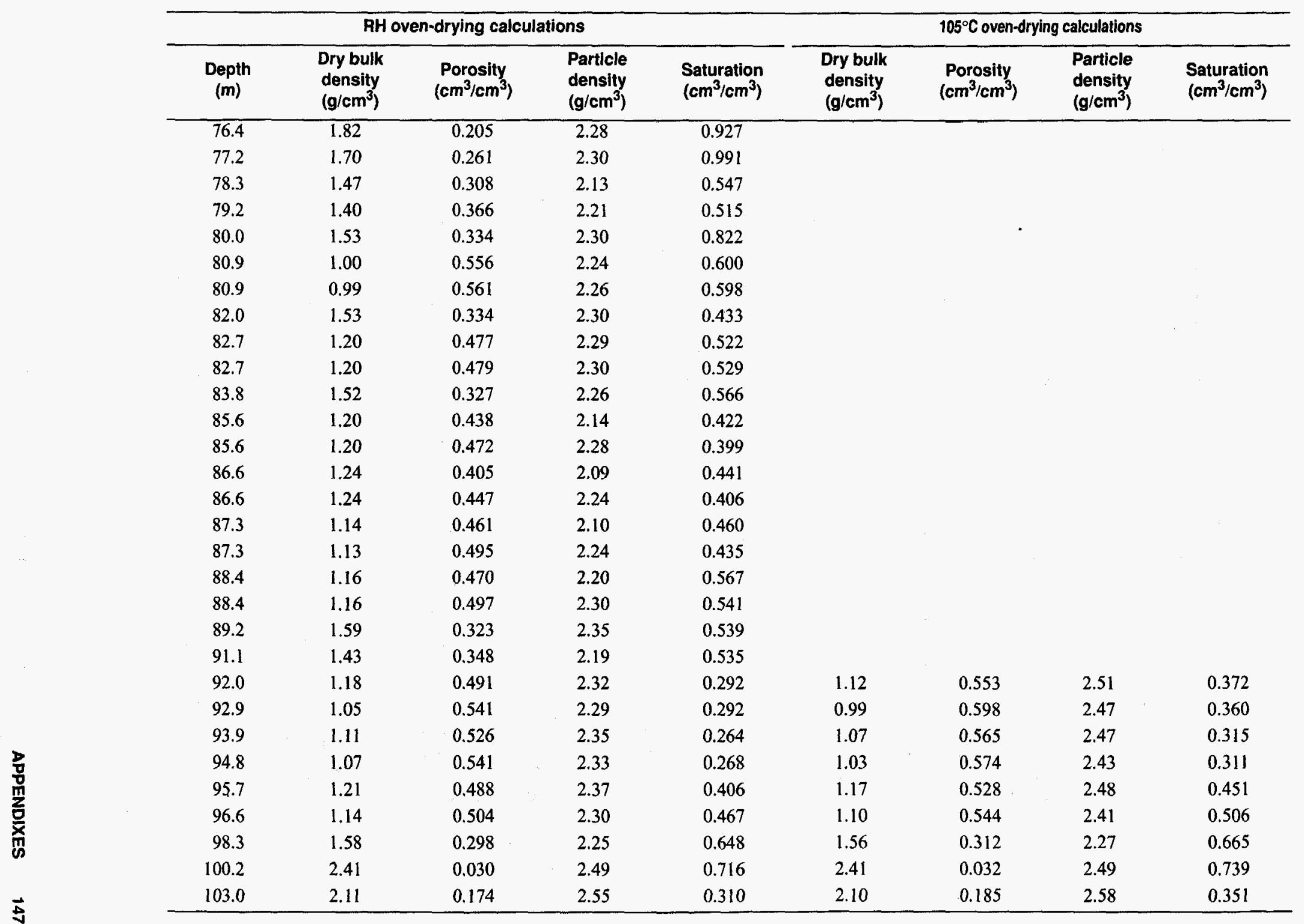


$\vec{\Phi} \quad$ Hydrologic-Property Measurements of UZ-14 Core Samples at Yucca Mountain, Nevada

\begin{tabular}{|c|c|c|c|c|c|c|c|c|c|c|}
\hline 응 & $\begin{array}{l}\text { [RH, relative } \\
\text { during saturat }\end{array}$ & $\begin{array}{l};{ }^{\circ} \mathrm{C} \text {, degre } \\
\text { les are ques }\end{array}$ & $\begin{array}{l}\text { ius; m, meter } \\
\text { le; \&, questio }\end{array}$ & $\begin{array}{l}\text { gram per } \\
\text { saturation } \mathrm{V}\end{array}$ & entimeter; $\mathrm{cm}$ & cubic cent & er cubic cent & ;*, sampl & aggregated & \\
\hline$\stackrel{\text { p }}{\underline{p}}$ & & $\mathbf{R H}$ & 1-drying calc & ons & & & $105^{\circ} \mathrm{C}$ oven-d & calculations & & \\
\hline 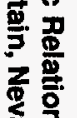 & $\begin{array}{l}\text { Depth } \\
\text { (m) }\end{array}$ & $\begin{array}{c}\text { Dry bulk } \\
\text { density } \\
\left(\mathrm{g} / \mathrm{cm}^{3}\right)\end{array}$ & $\begin{array}{c}\text { Porosity } \\
\left(\mathrm{cm}^{3} / \mathrm{cm}^{3}\right)\end{array}$ & $\begin{array}{l}\text { Particle } \\
\text { density } \\
\left(\mathrm{g} / \mathrm{cm}^{3}\right)\end{array}$ & $\begin{array}{l}\text { Saturation } \\
\left(\mathrm{cm}^{3} / \mathrm{cm}^{3}\right)\end{array}$ & $\begin{array}{l}\text { Dry bulk } \\
\text { density } \\
\left(\mathrm{g} / \mathrm{cm}^{3}\right)\end{array}$ & $\begin{array}{l}\text { Porosity } \\
\left(\mathrm{cm}^{3} / \mathrm{cm}^{3}\right)\end{array}$ & $\begin{array}{l}\text { Particle } \\
\text { density } \\
\left(\mathrm{g} / \mathrm{cm}^{3}\right)\end{array}$ & $\begin{array}{l}\text { Saturation } \\
\left(\mathrm{cm}^{3} / \mathrm{cm}^{3}\right)\end{array}$ & \\
\hline 兘 & 12.2 & 2.17 & 0.117 & 2.46 & 0.829 & 2.15 & 0.136 & 2.49 & 0.854 & \\
\hline ב & 13.0 & 2.06 & 0.168 & 2.47 & 1.150 & 2.04 & 0.181 & 2.49 & 1.139 & $\&$ \\
\hline 胥 & 14.2 & 2.04 & 0.176 & 2.48 & 0.930 & 2.05 & 0.172 & 2.47 & 0.928 & \\
\hline 음 & 15.3 & 2.05 & 0.174 & 2.49 & 0.940 & 2.05 & 0.183 & 2.50 & 0.943 & \\
\hline$\cong$ & 16.1 & 2.07 & 0.166 & 2.48 & 0.903 & 2.06 & 0.177 & 2.50 & 0.910 & \\
\hline$\stackrel{0}{0}$ & 17.2 & 2.07 & 0.166 & 2.48 & 0.886 & 2.05 & 0.179 & 2.50 & 0.894 & \\
\hline$\overline{0}$ & 18.5 & 2.00 & 0.191 & 2.48 & 0.938 & 1.99 & 0.208 & 2.51 & 0.943 & \\
\hline & 19.8 & 1.81 & 0.186 & 2.23 & 1.006 & 1.68 & 0.321 & 2.47 & 1.003 & \\
\hline כ & 20.4 & 1.75 & 0.210 & 2.22 & 1.123 & 1.65 & 0.311 & 2.40 & 1.083 & \\
\hline 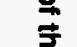 & 21.5 & 1.53 & 0.308 & 2.21 & 0.984 & 1.42 & 0.416 & 2.43 & 0.988 & \\
\hline & 22.1 & 1.49 & 0.328 & 2.21 & 1.004 & 1.39 & 0.425 & 2.42 & 1.003 & \\
\hline $\boldsymbol{Z}$ & 23.4 & 1.43 & 0.279 & 1.98 & 0.690 & 1.36 & 0.347 & 2.08 & 0.751 & $* *$ \\
\hline & 24.1 & 1.56 & 0.357 & 2.42 & 0.507 & 1.48 & 0.437 & 2.62 & 0.597 & \\
\hline$\frac{5}{3}$ & 25.1 & 1.54 & 0.329 & 2.29 & 0.457 & 1.49 & 0.373 & 2.38 & 0.521 & \\
\hline$\vec{E}$ & 26.7 & 1.33 & 0.418 & 2.28 & 0.612 & 1.26 & 0.481 & 2.43 & 0.663 & \\
\hline$z$ & 28.7 & 1.33 & 0.420 & 2.29 & 0.589 & 1.26 & 0.485 & 2.45 & 0.644 & \\
\hline$\stackrel{9}{g}$ & 29.9 & 1.52 & 0.298 & 2.17 & 0.556 & 1.44 & 0.377 & 2.32 & 0.650 & \\
\hline$\frac{\Phi}{a}$ & 30.9 & 1.12 & 0.492 & 2.20 & 0.486 & 1.05 & 0.556 & 2.37 & 0.545 & \\
\hline$\frac{1}{8}$ & 31.7 & 1.00 & 0.538 & 2.16 & 0.447 & 0.93 & 0.606 & 2.36 & 0.509 & \\
\hline च्र & 32.6 & 1.10 & 0.481 & 2.12 & 0.473 & 1.04 & 0.544 & 2.28 & 0.535 & \\
\hline$\underline{z}$ & 33.6 & 1.20 & 0.438 & 2.13 & 0.517 & 1.14 & 0.499 & 2.27 & 0.576 & \\
\hline \ัI & 34.5 & 1.16 & 0.445 & 2.10 & 0.533 & 1.22 & 0.388 & 2.00 & 0.465 & $* *$ \\
\hline 흠 & 35.2 & 1.17 & 0.441 & 2.09 & 0.508 & 1.02 & 0.591 & 2.49 & 0.633 & \\
\hline$\stackrel{8}{\circ}$ & 36.5 & 1.08 & 0.485 & 2.10 & 0.467 & 1.04 & 0.525 & 2.19 & 0.509 & \\
\hline$\stackrel{\cap}{c}$ & 37.3 & 1.13 & 0.478 & 2.16 & 0.465 & 1.09 & 0.517 & 2.25 & 0.505 & \\
\hline & 38.1 & 1.18 & 0.460 & 2.18 & 0.485 & 1.14 & 0.501 & 2.27 & 0.527 & \\
\hline & 39.0 & 1.09 & 0.491 & 2.14 & 0.400 & 1.06 & 0.522 & 2.21 & 0.435 & \\
\hline & 39.9 & 1.14 & 0.486 & 2.22 & 0.402 & 1.11 & 0.518 & 2.30 & 0.439 & \\
\hline & 40.8 & 1.16 & 0.450 & 2.11 & 0.445 & 1.13 & 0.482 & 2.18 & 0.482 & \\
\hline
\end{tabular}


Hydrologic-Property Measurements of UZ-14 Core Samples at Yucca Mountain, Nevada--Continued

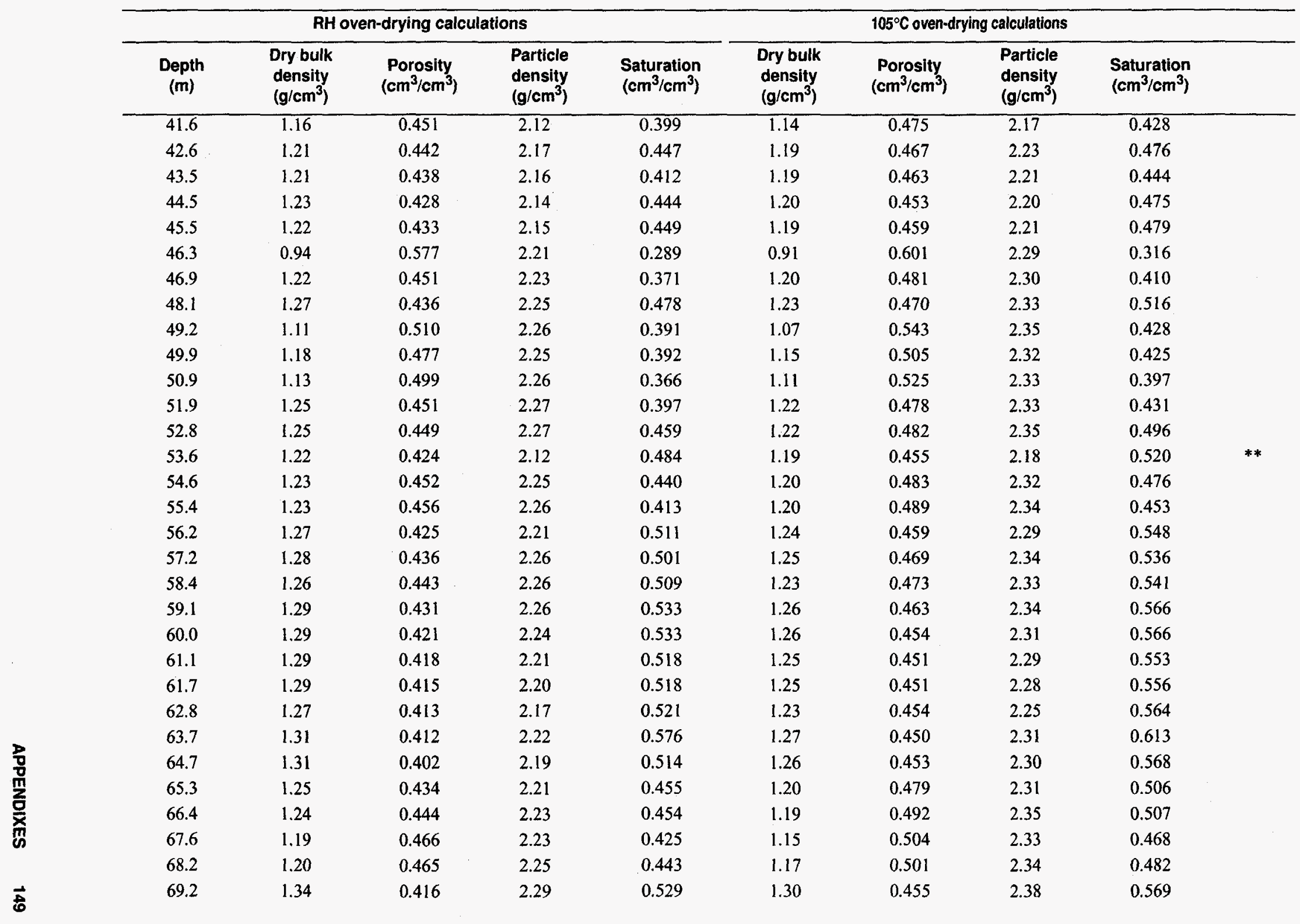


Hydrologic-Property Measurements of UZ-14 Core Samples at Yucca Mountain, Nevada--Continued

\begin{tabular}{|c|c|c|c|c|c|c|c|c|c|}
\hline \multirow[b]{2}{*}{$\begin{array}{l}\text { Depth } \\
(\mathbf{m})\end{array}$} & \multicolumn{3}{|c|}{ RH oven-drying calculations } & \multirow[b]{2}{*}{$\begin{array}{l}\text { Saturation } \\
\left(\mathrm{cm}^{3} / \mathrm{cm}^{3}\right)\end{array}$} & \multicolumn{3}{|c|}{$105^{\circ} \mathrm{C}$ oven-drying calculations } & \multirow[b]{2}{*}{$\begin{array}{l}\text { Saturation } \\
\left(\mathrm{cm}^{3} / \mathrm{cm}^{3}\right)\end{array}$} & \\
\hline & $\begin{array}{l}\text { Dry bulk } \\
\text { density } \\
\left(\mathrm{g} / \mathrm{cm}^{3}\right)\end{array}$ & $\begin{array}{c}\text { Porosity } \\
\left(\mathrm{cm}^{3} / \mathrm{cm}^{3}\right)\end{array}$ & $\begin{array}{l}\text { Particle } \\
\text { density } \\
\left(\mathrm{g} / \mathrm{cm}^{3}\right)\end{array}$ & & $\begin{array}{l}\text { Dry bulk } \\
\text { density } \\
\left(\mathrm{g} / \mathrm{cm}^{3}\right)\end{array}$ & $\begin{array}{c}\text { Porosity } \\
\left(\mathrm{cm}^{3} / \mathrm{cm}^{3}\right)\end{array}$ & $\begin{array}{l}\text { Particle } \\
\text { density } \\
\left(\mathrm{g} / \mathrm{cm}^{3}\right)\end{array}$ & & \\
\hline 70.0 & 1.26 & 0.441 & 2.25 & 0.427 & 1.21 & 0.490 & 2.37 & 0.484 & \\
\hline 71.0 & 1.13 & 0.502 & 2.27 & 0.420 & 1.10 & 0.533 & 2.36 & 0.454 & \\
\hline 71.8 & 1.19 & 0.482 & 2.29 & 0.443 & 1.15 & 0.512 & 2.37 & 0.476 & \\
\hline 72.8 & 1.26 & 0.439 & 2.24 & 0.455 & 1.20 & 0.493 & 2.37 & 0.515 & \\
\hline 73.9 & 1.47 & 0.349 & 2.27 & 0.310 & 1.41 & 0.410 & 2.40 & 0.412 & \\
\hline 74.4 & 1.24 & 0.442 & 2.22 & 0.301 & 1.17 & 0.516 & 2.41 & 0.402 & \\
\hline 75.5 & 1.02 & 0.552 & 2.29 & 0.283 & 0.99 & 0.585 & 2,39 & 0.323 & \\
\hline 77.4 & 1.04 & 0.540 & 2.25 & 0.219 & 1.02 & 0.560 & 2.31 & 0.247 & \\
\hline 78.3 & 1.10 & 0.515 & 2.27 & 0.276 & 1.07 & 0.546 & 2.36 & 0.317 & \\
\hline 79.4 & 1.12 & 0.505 & 2.25 & 0.262 & 1.08 & 0.537 & 2.34 & 0.306 & \\
\hline 79.9 & 1.10 & 0.514 & 2.26 & 0.237 & 1.06 & 0.549 & 2.36 & 0.286 & \\
\hline 85.0 & 1.06 & 0.519 & 2.21 & 0.277 & 1.03 & 0.558 & 2.32 & 0.327 & \\
\hline 86.4 & 2.36 & 0.029 & 2.43 & 1.000 & 2.36 & 0.031 & 2.44 & 1.000 & $\&$ \\
\hline 87.6 & 2.46 & 0.031 & 2.54 & 0.280 & 2.45 & 0.042 & 2.55 & 0.463 & \\
\hline 88.5 & 2.47 & 0.014 & 2.50 & 0.387 & 2.46 & 0.021 & 2.51 & 0.603 & \\
\hline 89.1 & 2.46 & 0.016 & 2.50 & 0.317 & 2.45 & 0.025 & 2.52 & 0.560 & \\
\hline
\end{tabular}

Hydrologic-Property Measurements of UZ \#16 Core Samples at Yucca Mountain, Nevada

$\left[\mathrm{RH}\right.$, relative humidity; ${ }^{\circ} \mathrm{C}$, degree Celsius; $\mathrm{m}$, meter; $\mathrm{g} / \mathrm{cm}^{3}$, gram per cubic centimeter; $\mathrm{cm}^{3} / \mathrm{cm}^{3}$, cubic centimeter per cubic centimeter]

\begin{tabular}{|c|c|c|c|c|c|c|c|c|}
\hline \multicolumn{5}{|c|}{ RH oven-drying calculations } & \multicolumn{4}{|c|}{$105^{\circ} \mathrm{C}$ oven-drying calculations } \\
\hline $\begin{array}{l}\text { Depth } \\
\text { (m) }\end{array}$ & $\begin{array}{l}\text { Dry bulk } \\
\text { density } \\
\left(\mathrm{g} / \mathrm{cm}^{3}\right)\end{array}$ & $\begin{array}{c}\text { Porosity } \\
\left(\mathrm{cm}^{3} / \mathrm{cm}^{3}\right)\end{array}$ & $\begin{array}{l}\text { Particle } \\
\text { density } \\
\left(g / \mathrm{cm}^{3}\right)\end{array}$ & $\begin{array}{l}\text { Saturation } \\
\left(\mathrm{cm}^{3} / \mathrm{cm}^{3}\right)\end{array}$ & $\begin{array}{l}\text { Dry bulk } \\
\text { density } \\
\left(\mathrm{g} / \mathrm{cm}^{3}\right)\end{array}$ & $\begin{array}{c}\text { Porosity } \\
\left(\mathrm{cm}^{3} / \mathrm{cm}^{3}\right)\end{array}$ & $\begin{array}{l}\text { Particle } \\
\text { density } \\
\left(\mathrm{g} / \mathrm{cm}^{3}\right)\end{array}$ & $\begin{array}{l}\text { Saturation } \\
\left(\mathrm{cm}^{3} / \mathrm{cm}^{3}\right)\end{array}$ \\
\hline 40.0 & 2.33 & 0.052 & 2.46 & 0.977 & 2.31 & 0.069 & 2.48 & 0.982 \\
\hline 40.7 & 2.31 & 0.064 & 2.46 & 0.766 & 2.29 & 0.083 & 2.50 & 0.821 \\
\hline 41.4 & 2.37 & 0.037 & 2.46 & 0.902 & 2.36 & 0.048 & 2.48 & 0.926 \\
\hline 44.4 & 1.89 & 0.202 & 2.36 & 0.762 & 1.81 & 0.276 & 2.50 & 0.826 \\
\hline
\end{tabular}


Hydrologic-Property Measurements of UZ \#16 Core Samples at Yucca Mountain, Nevada--Continued

\begin{tabular}{|c|c|c|c|c|c|c|c|c|}
\hline \multicolumn{5}{|c|}{ RH oven-drying calculations } & \multicolumn{4}{|c|}{$105^{\circ} \mathrm{C}$ oven-drying calculations } \\
\hline $\begin{array}{l}\text { Depth } \\
\text { (m) }\end{array}$ & $\begin{array}{l}\text { Dry bulk } \\
\text { density } \\
\left(\mathrm{g} / \mathrm{cm}^{3}\right)\end{array}$ & $\begin{array}{l}\text { Porosity } \\
\left(\mathrm{cm}^{3} / \mathrm{cm}^{3}\right)\end{array}$ & $\begin{array}{l}\text { Particle } \\
\text { density } \\
\left(\mathrm{g} / \mathrm{cm}^{3}\right)\end{array}$ & $\begin{array}{l}\text { Saturation } \\
\left(\mathrm{cm}^{3} / \mathrm{cm}^{3}\right)\end{array}$ & $\begin{array}{l}\text { Dry bulk } \\
\text { density } \\
\left(\mathrm{g} / \mathrm{cm}^{3}\right)\end{array}$ & $\begin{array}{l}\text { Porosity } \\
\left(\mathrm{cm}^{3} / \mathrm{cm}^{3}\right)\end{array}$ & $\begin{array}{l}\text { Particle } \\
\text { density } \\
\left(\mathrm{g} / \mathrm{cm}^{3}\right)\end{array}$ & $\begin{array}{l}\text { Saturation } \\
\left(\mathrm{cm}^{3} / \mathrm{cm}^{3}\right)\end{array}$ \\
\hline 47.5 & 1.44 & 0.353 & 2.22 & 0.613 & 1.37 & 0.419 & 2.36 & 0.674 \\
\hline 48.4 & 1.36 & 0.388 & 2.23 & 0.467 & 1.34 & 0.412 & 2.28 & 0.498 \\
\hline 49.3 & 1.24 & 0.458 & 2.29 & 0.568 & 1.18 & 0.521 & 2.46 & 0.620 \\
\hline 50.3 & 1.58 & 0.324 & 2.34 & 0.309 & 1.56 & 0.347 & 2.39 & 0.355 \\
\hline 51.1 & 1.31 & 0.414 & 2.24 & 0.298 & 1.29 & 0.436 & 2.29 & 0.334 \\
\hline 52.3 & 1.25 & 0.436 & 2.22 & 0.272 & 1.24 & 0.452 & 2.25 & 0.298 \\
\hline 53.4 & 1.59 & 0.314 & 2.32 & 0.505 & 1.56 & 0.344 & 2.38 & 0.548 \\
\hline 54.4 & 1.19 & 0.499 & 2.37 & 0.336 & 1.17 & 0.517 & 2.42 & 0.359 \\
\hline 55.6 & 1.55 & 0.331 & 2.32 & 0.430 & 1.49 & 0.391 & 2.45 & 0.518 \\
\hline 56.9 & 1.13 & 0.507 & 2.29 & 0.406 & 1.07 & 0.569 & 2.48 & 0.471 \\
\hline 58.0 & 1.45 & 0.378 & 2.33 & 0.376 & 1.41 & 0.418 & 2.43 & 0.436 \\
\hline 58.9 & 1.26 & 0.443 & 2.26 & 0.342 & 1.23 & 0.472 & 2.33 & 0.383 \\
\hline 60.0 & 1.07 & 0.536 & 2.31 & 0.303 & 1.05 & 0.563 & 2.39 & 0.336 \\
\hline 60.8 & 1.03 & 0.552 & 2.31 & 0.307 & 1.01 & 0.574 & 2.38 & 0.334 \\
\hline 61.6 & 1.03 & 0.527 & 2.18 & 0.222 & 1.02 & 0.539 & 2.21 & 0.238 \\
\hline 62.7 & 0.94 & 0.579 & 2.24 & 0.213 & 0.93 & 0.594 & 2.29 & 0.233 \\
\hline 63.6 & 0.94 & 0.587 & 2.27 & 0.246 & 0.92 & 0.600 & 2.31 & 0.263 \\
\hline 64.5 & 0.90 & 0.597 & 2.24 & 0.203 & 0.89 & 0.614 & 2.30 & 0.224 \\
\hline 65.4 & 0.90 & 0.594 & 2.22 & 0.206 & 0.88 & 0.614 & 2.28 & 0.232 \\
\hline 66.3 & 0.99 & 0.576 & 2.32 & 0.222 & 0.96 & 0.604 & 2.42 & 0.259 \\
\hline 67.3 & 1.25 & 0.481 & 2.42 & 0.300 & 1.20 & 0.534 & 2.58 & 0.370 \\
\hline 68.9 & 1.46 & 0.398 & 2.43 & 0.108 & 1.45 & 0.413 & 2.46 & 0.139 \\
\hline 69.6 & 1.77 & 0.247 & 2.35 & 0.166 & 1.72 & 0.290 & 2.43 & 0.290 \\
\hline 70.2 & 2.38 & 0.030 & 2.45 & 0.410 & 2.37 & 0.040 & 2.47 & 0.553 \\
\hline 71.1 & 2.43 & 0.023 & 2.48 & 0.775 & 2.42 & 0.028 & 2.49 & 0.820 \\
\hline 71.9 & 2.41 & 0.038 & 2.51 & 1.023 & 2.40 & 0.057 & 2.54 & 1.015 \\
\hline 74.6 & 2.31 & 0.096 & 2.56 & 0.376 & 2.30 & 0.108 & 2.58 & 0.446 \\
\hline
\end{tabular}

